DEIGLES GIACOMELLI AMARO

\title{
INDÍCIOS DA APRENDIZAGEM DE CRIANÇAS COM DEFICIÊNCIA EM ESCOLAS DE EDUCAÇÃO INFANTIL: \\ roteiro de observação no cotidiano escolar
}

SÃO PAULO

2004 


\section{INDÍCIOS DA APRENDIZAGEM DE CRIANÇAS COM DEFICIÊNCIA EM ESCOLAS DE EDUCAÇÃO INFANTIL: roteiro de observação no cotidiano escolar}

Dissertação apresentada ao Instituto de Psicologia da Universidade de São Paulo como parte dos requisitos para obtenção do grau de Mestre em Psicologia.

Área de Concentração: Psicologia Escolar e do Desenvolvimento Humano

Orientador: Prof. Dr. Lino de Macedo 


\title{
INDÍCIOS DA APRENDIZAGEM DE CRIANÇAS COM DEFICIÊNCIA EM ESCOLAS DE EDUCAÇÃO INFANTIL: roteiro de observação no cotidiano escolar
}

\author{
DEIGLES GIACOMELLI AMARO
}

BANCA EXAMINADORA

(Nome e Assinatura)

(Nome e Assinatura)

(Nome e Assinatura)

Dissertação defendida e aprovada em: 


\section{DEDICATÓRIA}

Ao meu pai que apostou simbolicamente que seus filhos poderiam ser aquilo que gostariam de ser, independente do que fossem.

Guardo na memória do meu coração todos seus atos que inconscientemente semearam o meu desejo de estudar e trabalhar para que as pessoas vivam melhor.

Fico triste por não ter ao meu lado sua presença física neste momento.

Mas, fico muito feliz e agradecida, porque as marcas que deixou na minha vida, me possibilitaram estar aqui!

Minha mãe Vera, meus irmãos Douglas e Deivisom, realizar este trabalho foi possível porque vocês me ofereceram a sustentação necessária para isto.

Vocês foram a base da minha educação.

Minha família ... com quem aprendi os valores mais importantes da minha vida.

Eu sei os esforços que cada um de vocês fizeram para que as nossas vidas seguissem da melhor forma possível.

Como agradecer por terem me ajudado a estar hoje concluindo este trabalho?

Como agradecer por ser filha e irmã de vocês?

A todos aqueles que agem no cotidiano para que as pessoas - independente de suas características físicas, psíquicas, cognitivas, culturais e sociais - se desenvolvam, aprendam e vivam com dignidade, alegria e amor. 


\section{AGRADECIMENTOS}

São muitas as pessoas a quem eu gostaria de agradecer. Para mim, agradecer é fundamental. Este trabalho só se tornou o que é, pela contribuição que muitas pessoas tiveram no percurso de minha vida. Gostaria que todas as pessoas que passaram por ela, recebessem a minha gratidão. Pois, de alguma maneira, elas contribuíram na minha formação. Entretanto, neste momento, só é possível agradecer diretamente a algumas...

Professor Lino de Macedo, como fui feliz em ser sua orientanda! Fico extremamente admirada pela forma de você conduzir o processo de construção do conhecimento. Nunca vi uma pessoa mais coerente e mais dedicada a praticar aquilo que acredita: os princípios construtivistas. Seus enunciados teóricos ... sua disciplina ... o seu respeito pelas minhas hipóteses e experiências prévias ... a sua intervenção cuidadosa em todos os momentos deste percurso ... o seu investimento para que o trabalho progredisse ... a sua valorização de cada etapa realizada ... a sua forma afetiva de lidar com os alunos ... auxiliaram-me a superar as minhas dificuldades e a elaborar esta dissertação da melhor forma possível para mim...

Professora Rosângela Gavioli Prieto, suas contribuições no exame de qualificação foram muito importantes para o desenrolar do meu trabalho. Suas sugestões foram instigantes de reflexões e elucidativas de algumas dúvidas. Além disso, considero que elas são mais pistas neste caminho rumo a uma educação inclusiva no município de Mauá, no qual sua participação, foi fundamental...

Professora Marilene Proença Rebello de Souza, sua leitura cuidadosa e precisa do meu texto de qualificação e as questões problematizadas por você, muito contribuíram para eu encontrar melhores caminhos para apresentar esta dissertação. Espero que este texto lhe retribua, humildemente, o que você iniciou a semear anos atrás no município em que trabalho: uma educação menos estigmatizadora e de mais qualidade... 
Professora Lígia Assumpção Amaral, se anjo existe, certamente você foi um anjo para mim! Ou como você dizia, "minha madrinha". Não esquecerei seus ensinamentos sobre estereótipos, estigmas e preconceitos envolvidos nos processos de aceitação das pessoas com diferenças significativas...

Professor José Leon Crochik, sua disciplina foi minha primeira aproximação no percurso da pós-graduação. Uma das mensagens mais importantes que me marcou, foi sobre a necessidade de refletirmos sobre nossas ações e valores para "combatermos" os preconceitos...

Professora Leny Magalhães Mrech, na sua disciplina vivi uma boa experiência educacional inclusiva. Com alunos com diferentes formações e com uma referência teórica complexa: a psicanálise, você proporcionou que a Educação Inclusiva fosse discutida na sua dimensão interdisciplinar e como um caminho em constante construção...

Professora Maria Lúcia Toledo Moraes Amiralian, estudar o desenvolvimento de pessoas com deficiência a luz da teoria Winnicottiana foi muito bom. Reforçou minha crença de que a Educação Inclusiva pode ser um "ambiente suficientemente bom" para o aprendizado de crianças com deficiência...

Professora Maria Thereza Costa Coelho de Souza, Professor Yves de La Taille e Professora Maria Isabel Leme de Mattos, estudar a construção cognitiva, moral e cultural do si-mesmo foi fundamental para compreender o desenvolvimento e a aprendizagem das crianças e os fatores que contribuem neste processo...

Renata Rampazo, Mônica Ribeiro, Mônica Fogaça, Marilda Ribeiro, Maria Carolina Villas Boas, Marcia Torres, Marcia L. Oliveira, Maria Célia Campos, Ivonete Tamboril, Heloísa Garcia, Flávio Frasseto, meus colegas de orientação com quem convivi e compartilhei o aprendizado deste processo de construção de um trabalho científico construtivista. Seus "olhares" para a "minha" e "nossa" pesquisa, 
valorizaram a perspectiva coletiva do trabalho. Foi muito bom ter vocês como parceiros neste caminho ...

Lilian J. Ruas Lucio, sua intervenção profissional foi essencial para sustentar uma fase tão delicada e tão importante da minha vida...

Érick, Ítalo Júlio, suas mães e profissionais das suas escolas, a disponibilidade que vocês ofereceram durante todo o percurso foi fundamental para que este trabalho se realizasse. As histórias aqui apresentadas sobre suas relações no cotidiano escolar, explicitam que podemos "confiar" que uma educação inclusiva é possível e favorável ao desenvolvimento e à aprendizagem de pessoas com deficiência. Espero que esta dissertação traga elementos que nos assegurem que estamos num caminho promissor...

Meus amigos e companheiros de trabalho do Centro Municipal de Educação Inclusiva Cleberson da Silva, profissionais das escolas e da Secretaria Municipal de Educação, Cultura, Esportes e Lazer de Mauá, alunos e pais com que tive contato durante estes meus anos de atuação profissional neste município, foi trabalhando com vocês que tive as experiências mais marcantes da minha vida profissional. Foram elas que me motivaram a desenvolver este trabalho...

Solange, Simone, Renata, Odinete, Marcia, Juliana, Jane, Helena, Eliza, Eliana, Edna, Edila, Dagmar, Dalva, Daniela, Cida Zavatieri, Cida Torres, Cecília, Alessandra, Alex, Aida, vocês conviveram ou convivem muito próximos de mim no meu trabalho. Acompanharam dia após dia este processo e minhas inquietações profissionais. É no meu cotidiano de trabalho com vocês que eu estou aprendendo a trabalhar em equipe, a respeitar e valorizar as diferenças, a ter a certeza de que uma educação inclusiva, embora muito complexa, é desejável e possível. Vocês me ouviram, me fizeram pensar, me estimularam a ir em frente... 
Patrícia, Gleidis e Rosa, representantes da direção e coordenação do Centro Municipal de Educação Inclusiva Cleberson da Silva, pela compreensão e colaboração nos momentos delicados do meu processo da pós-graduação...

Giu, você sabe o quanto foi e é importante na minha vida. Minha formação profissional e esta dissertação foram incentivadas por você. Você me ajudou a ter convicção de que este era um caminho importante para mim...

$F \hat{e}$, sua sensibilidade para me compreender e compreender o que eu estava produzindo neste trabalho ... sua leitura cuidadosa ... suas correções e sugestões no texto inicial daquilo que esta dissertação se tornaria, foram contribuições que guardarei sempre no meu coração...

Alessandra, Andréa, Fernando, Rita, Wania, amigos que estiveram ao meu lado me lembrando das outras coisas da vida que andam em paralelo ao trabalho, vocês me emprestaram seus ombros, me sacudiram, propiciaram momentos de distanciamento das minhas angústias. Como é bom ter vocês na minha vida ...

Alessandra Gonzales, minha amiga! Seu nome representa toda a admiração, respeito e consideração que tenho por todas as terapeutas ocupacionais que fizeram parte da minha formação e atuação profissional...

Meus tios, minhas tias, meus primos, minhas primas, Cris, Douglinhas, Geraldo, Raquel, Eni, cada um do seu jeito, apoiaram-me carinhosamente neste percurso...

Muito obrigada!!! 
Razão que não passa pelo coração não tem a magia de transformar o fazer e o pensar na arte de construir conhecimentos autônomos e humanos com alegria, prazer e amor 


\section{SUMÁRIO}

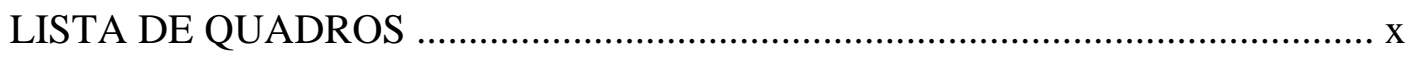

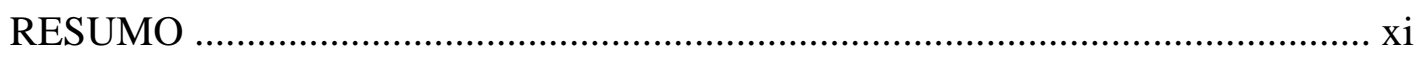

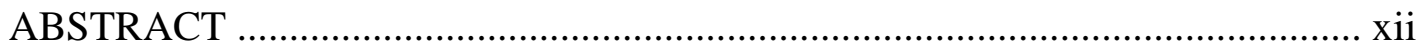

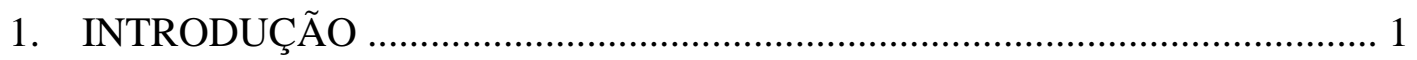

1.1. Apresentação ………................................................................... 1

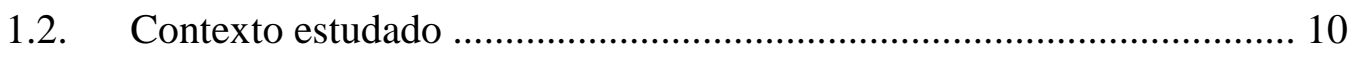

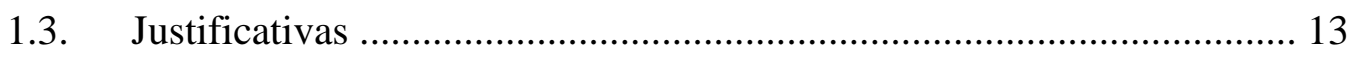

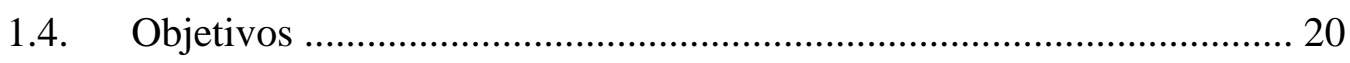

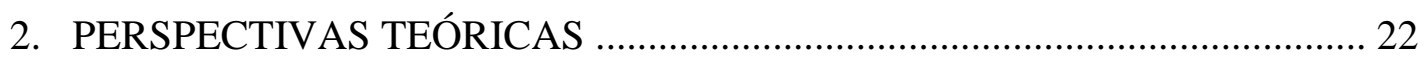

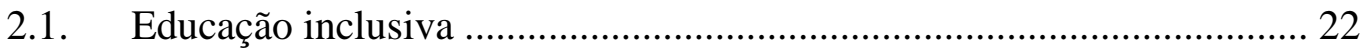

2.1.1. Educação inclusiva: uma leitura construtuvista ............................ 23

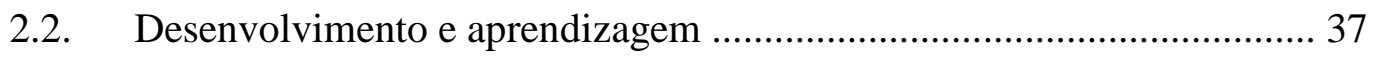

2.2.1. Desenvolvimento e aprendizagem em pessoas com deficiência ...... 46

2.3. Cotidiano e cotidiano escolar................................................................. 58

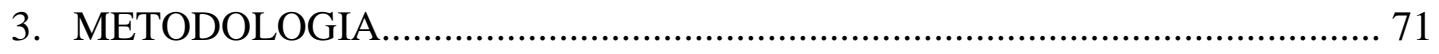

3.1. Pesquisa construtivista ….................................................................. 71

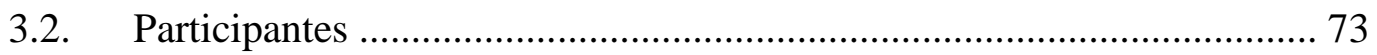

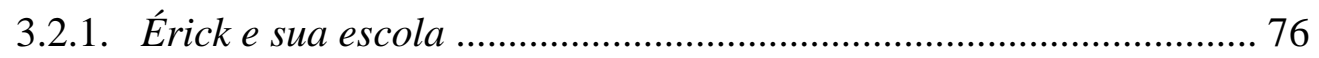

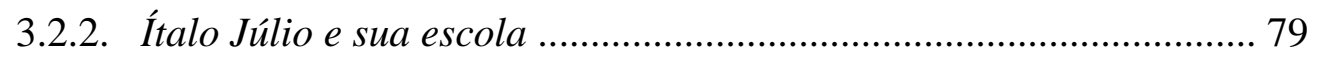

3.3. Instrumentos e procedimentos de coleta de dados .............................. 81

3.4. Critérios de organização, apresentação e discussão dos dados .............. 88

4. APRESENTAÇÃO DOS DADOS: Construindo histórias ................................ 90

4.1. Érick e suas relações no cotidiano escolar ............................................ 90

4.1.1. Uma possível síntese da história de Érick................................... 114

4.2. Ítalo Júlio e suas relações no cotidiano escolar ................................... 117

4.2.1. Uma possível síntese da história de Ítalo Júlio ............................. 138 
6. CONSIDERAÇÕES FINAIS. 170

REFERÊNCIAS BIBLIOGRÁFICAS 173

ANEXO 1 - Roteiro de observação do aluno no cotidiano escolar 189

ANEXO 2 - Roteiro de observação do aluno no cotidiano em casa 190

ANEXO 3 - Diário de observação do aluno 196

ANEXO 4 - Cronograma da pesquisa de campo 198

ANEXO 5 - Roteiro da entrevista final de coleta de dados do aluno Érick 201

ANEXO 6 - Roteiro da entrevista final de coleta de dados do aluno Ítalo Júlio .... 205

ANEXO 7 - Indícios do desenvolvimento e aprendizagem do aluno Érick 210

ANEXO 8 - Indícios do desenvolvimento e aprendizagem do aluno Ítalo Júlio.... 234 ANEXO 9 - Solicitação de autorização para a SMECE da cidade de Mauá. 249 ANEXO 10 - Termo de Consentimento Livre e Esclarecido 251 


\section{LISTA DE QUADROS}

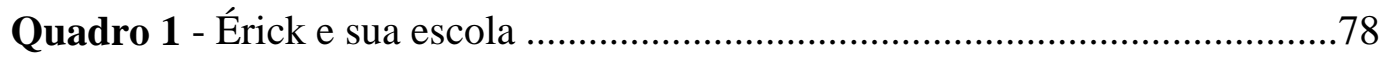

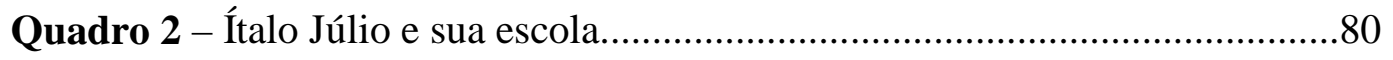




\section{RESUMO}

AMARO, Deigles Giacomelli. Indícios da aprendizagem de crianças com deficiência em escolas de educação infantil: roteiro de observação no cotidiano escolar. São Paulo, 2004. 252p. Dissertação (Mestrado). Instituto de Psicologia, Universidade de São Paulo.

Esta pesquisa teve como objetivo estudar por que e quais as relações estabelecidas no cotidiano escolar podem beneficiar o desenvolvimento e a aprendizagem de alunos com deficiência em escolas regulares. Para isso, um roteiro de observação foi elaborado baseado nas relações do aluno com pessoas, espaço, tempo, objetos e atividades no cotidiano escolar. Este roteiro foi utilizado para orientar a observação, intervenção e registros dos professores e demais profissionais da escola sobre dois alunos de cinco anos (um com paralisia cerebral do tipo tetraparesia espástica e outro com síndrome de Down) de duas escolas de educação infantil de Mauá/SP. Ao longo de oito meses, a pesquisadora realizou entrevistas com os profissionais das escolas e com as mães dos alunos. A intervenção desta, norteada pelo roteiro, teve o objetivo de evidenciar a importância da observação e reflexão no cotidiano escolar para que a singularidade do aluno seja respeitada e valorizada num contexto inclusivo. A apresentação dos dados é realizada por meio de histórias destacando-se os indícios que apontaram por que e quais relações favoreceram o progresso dos alunos. A discussão dos dados demonstrou a importância do estabelecimento de relações de interdependência para que uma educação inclusiva seja possível.

Palavras-chave: Educação Inclusiva; Cotidiano; Indícios; Desenvolvimento; Aprendizagem; Deficiência; Roteiro de observação. 


\begin{abstract}
AMARO, Deigles Giacomelli. Indications of the learning of children with deficiency in infantile education schools: script of comment in the school daily routine. São Paulo, 2004. 252p. Dissertation (Master Class). Institute of Psychology, University of São Paulo.
\end{abstract}

This research had as purpose to study why and which the relations established in the school daily routine can benefit the development and learning of pupils with deficiency in regular schools. For this, a comment script was elaborated based on the relations of the pupil with people, space, time, objects and activities in the school daily routine. This script was used to guide the comment, intervention and registers of teachers and other professionals about two five year pupils (one with cerebral paralysis of the espástica tetraparesia type and another one with syndrome of Down) from two infantile education schools in Mauá/SP. Throughout eight months, the researcher carried through interviews with the professionals of the schools and the mothers of the pupils. The intervention of this, guided for the script, had the purpose to evidence the importance of the comment and reflection in the school daily routine so that the singularity of the pupil is respected and valued in an inclusive context. The presentation of the data is carried through by mean of histories being distinguished the indications that had pointed why and which relations had favored the progress of the pupils. The quarrel of the data demonstrated the importance of the establishment of interdependence relations so that an inclusive education is possible.

Key-Words: Inclusive education; Daily routine; Indications; Development; Learning; Deficiency; Script of comment. 


\section{INTRODUÇÃO}

\subsection{Apresentação}

Peço licença para iniciar esta dissertação fazendo uma digressão - não-linear sobre meu percurso profissional, do início até este momento. Penso que a história pessoal auxilia a compreensão das escolhas que fazemos. Ela nos oferece indícios dos lugares aonde pretendemos ir.

Sou terapeuta ocupacional. Esta escolha profissional reflete meu interesse em desenvolver práticas favoráveis ao processo de inclusão social de pessoas que, por razão de ordem física, mental, psíquica e/ou social, têm esta problemática como ponto de partida (BENETTON, 1994). Aliado a isso, segue a minha crença de que as atividades cotidianas são imprescindíveis na vida de todo ser humano. É por meio delas que temos a possibilidade de nos constituir, desenvolver e aprender. Para Heller (1970/s.d.), a vida cotidiana é a vida de todo o homem, do homem inteiro.

O processo de realização de atividades cotidianas é, muitas vezes, simples e, outras tantas, complexo. Isto é, quando automatizamos algumas atividades, nem nos damos conta dos vários aspectos envolvidos em sua realização. Porém, quando, por algum motivo - como o prejuízo da movimentação ativa dos membros superiores ocasionados por uma lesão neurológica - a sua realização é comprometida, ficam evidenciadas a complexidade e a multiplicidade de fatores envolvidos na realização dessas atividades não só para as pessoas com déficit, mas para todas as pessoas.

Acredito que a realização dessas atividades envolve processos de construções cognitivas, morais, psíquicas, culturais e sociais. Esta é uma das razões que me fizeram escolher o Departamento de Psicologia Escolar e Desenvolvimento Humano para realizar este estudo.

Outra razão refere-se ao local de trabalho em que estou inserida nos últimos oito anos e ao exercício profissional que venho desempenhando. Atuo como terapeuta 
ocupacional no Centro Municipal de Educação Inclusiva Cleberson da Silva $(\mathrm{CEMEI})^{1}$ da Secretaria Municipal de Educação, Cultura e Esportes de Mauá (SMECE), região do Grande ABC - São Paulo. O CEMEI oferece atendimento e escolarização para crianças, adolescentes e adultos com deficiências diversas e/ou distúrbios globais do desenvolvimento. Ele também desenvolve ações de apoio às escolas do município para a inclusão de alunos com deficiência no ensino regular. As intervenções realizadas pela equipe da qual faço parte estão estruturadas nos seguintes eixos: atendimento aos alunos com deficiência; atendimento à família destes; acompanhamento e apoio aos profissionais da educação, cultura, esportes e lazer do município para assuntos relacionados à inclusão educacional e social; e, atividades com a comunidade para conscientização sobre os direitos e as possibilidades de participação social da pessoa com deficiência.

No plano de trabalho que apresentei para o processo de seleção deste programa, apresento as razões que me motivaram a cursar o programa de pósgraduação e realizar esta dissertação:

Atualmente sinto a necessidade de ingressar no programa de mestrado pela urgência de estudar e pesquisar as questões trazidas na minha experiência profissional, por dois motivos:

- $\quad$ o entendimento de que a reflexão e a articulação entre teoria e prática são condições imprescindíveis para um processo de trabalho consciente de sua função social e promotor (direta e indiretamente) de uma melhoria na qualidade de vida das pessoas;

- $\quad$ a consideração de que a experiência de trabalho que tenho atualmente é muito intensa, rica de acontecimentos e questionamentos que precisam ser compartilhados e pesquisados para contribuir com todos aqueles profissionais que se interessam por este contexto de trabalho e estudo.

Meu caminho de formação pessoal e profissional começou muito cedo: com minha família e com meus amigos; na educação infantil e nos ensinos fundamental e médio; na graduação e nos cursos de especialização e aperfeiçoamento; nos seminários, encontros e congressos dos quais participei. Enfim, a minha formação é marcada pelas relações que estabeleci com as pessoas, os espaços, os tempos, os objetos, as atividades das quais participei ... é marcada pela minha vivência cotidiana.

\footnotetext{
${ }^{1}$ Este é o atual nome do serviço público em que trabalho. Este nome foi modificado ao longo de sua história em decorrência das intenções de mudanças políticas e educacionais pelas quais o município passa desde 1997.
} 
Durante este trabalho, sempre que for pertinente, explicitarei contribuições que o caminho da minha formação me proporcionou. A minha intenção é valorizar o conhecimento como um processo de construção. E, como tal, é importante que minhas experiências profissionais, as disciplinas que cursei, os livros e textos que estudei, as discussões e reflexões realizadas com os colegas de orientação e com o orientador sejam relacionados neste trabalho. Lembro aqui a mensagem do professor Yves de La Taille que, ao aplicar a prova final de seu curso, ${ }^{2}$ nos disse o seguinte: "O que pretendo avaliar é como vocês podem relacionar as discussões e estudos realizados com a questão aqui colocada". Esta mensagem vincula-se à que está implícita em toda obra de Piaget: estabelecer relações é essencial no processo de construção do conhecimento.

Hoje, finalizando esta etapa da minha formação profissional, vou socializar o que eu, com o acompanhamento da visão teórica e atitudes construtivistas do meu orientador Prof. Dr. Lino de Macedo, pude desenvolver.

Esta dissertação está redigida ora na primeira pessoa do singular, com o intuito de assumir minhas peculiaridades neste percurso; ora na primeira pessoa do plural, já que, ao mesmo tempo, valorizo a colaboração do orientador e, como citado anteriormente, de tudo o que marcou a minha formação até o presente momento.

Outra opção que faço é usar a denominação pessoas ou crianças com deficiência. A questão da terminologia utilizada é extremamente polêmica na área. Não é meu intuito abordar esta problemática neste trabalho, entretanto, as palavras não são neutras. E, como adverte Carvalho, R. E. (1998, p.21): "a terminologia interfere no imaginário coletivo, produzindo sentimentos de rejeição e discriminação social [...] há, portanto, que empregar as palavras com cuidado alertando para seus sentidos conotativos e denotativos". Por isso, a minha opção está baseada na concordância com as considerações de Amaral (1995, p. 60-61):

[...] há vários anos vem sendo introduzido - em contraposição às "etiquetas" de deficiente, incapacitado, etc - o uso das expressões pessoas portadoras de e pessoas com [grifos da autora] (desta última sou ardorosa defensora) [...] usualmente os discursos acerca da deficiência não são retratos dela, mas retratos de como ela é interpretada através de parâmetros ideológicos [...] a forma verbal acentua o aspecto dinâmico da situação; desloca o eixo de atributo do indivíduo para sua condição e, simultaneamente, recupera a pessoa como " sujeito da frase”; coloca

\footnotetext{
${ }^{2}$ Disciplina cursada: Psicologia do desenvolvimento moral: "estado da arte" e as novas perspectivas. Instituto de Psicologia USP $-1^{\circ}$ semestre/2001.
} 
a deficiência não como sinônimo da pessoa (como ocorre ao tornar substantivo aquilo que é qualificativo).

Entretanto, no decorrer do trabalho, citarei outras nomenclaturas encontradas no material pesquisado para ser, o máximo possível, fiel a elas.

$\mathrm{Na}$ minha experiência de trabalho, percebo freqüentemente pessoas com deficiências que, embora tenham condições motoras, sensoriais e percepto-cognitivas suficientes para realizar atividades de cuidado próprio e de exploração do ambiente utilizando recursos próprios, não o fazem. Isto acaba por restringir suas possibilidades de desenvolvimento e de aprendizagem de habilidades e competências para estar e interagir no meio e para tomada de decisões que dizem respeito a si mesmas (MACEDO, 2001b). Carvalho, L.M.G. (1998) verifica que, mesmo havendo a participação de crianças com deficiência na rotina diária da família, elas têm pouca autonomia para decidir o que comer, vestir ou fazer. Estas decisões freqüentemente são tomadas pelos pais. Segundo Brunello (2001), o cotidiano da criança com deficiência é, muitas vezes, empobrecido nas relações afetivas e sociais sendo privadas de uma série de atividades condizentes com seu momento de vida.

Ao descreverem a história de como as pessoas com deficiência foram consideradas e tratadas ao longo do tempo, Amaral (1995), Aranha (2001), Bueno (1993), Carlo (1999), Ferreira (1989), Mazzotta (1982, 1993, 1996) e Pessotti (1984) encontraram representações e atitudes sociais marcadas por um caráter segregacionista, caritativo, assistencialista, filantrópico, paternalista e humanitário. A criação de instituições especializadas no tratamento e escolarização das pessoas com deficiência reflete estas características. Na maioria dos casos, essas instituições são estruturadas mantendo uma relação de superproteção e não-investimento nas possibilidades de desenvolvimento e de aprendizado das pessoas com deficiência. A zona dessas possibilidades estava limitada às "supostas" condições que a deficiência reservava para o aluno. A influência do saber médico marcou a prática da educação e imprimiu uma perspectiva "curativa" às deficiências. Esta pouco favoreceu o desenvolvimento e a aprendizagem dos alunos, pois o trabalho realizado focava seus limites e não suas possibilidades.

Apesar das mudanças conceituais e reflexões realizadas nos últimos anos nesta área do conhecimento, podemos perceber que muitas das práticas desenvolvidas ainda estão marcadas por estas características históricas (CARLO, 1999). 
Refletindo sobre essas constatações, a partir dos meus atendimentos a pais de pessoas com deficiência e, apoiada em trabalhos como o de Casarin (1997) e Sala (2003), percebo que os fatos acima relatados reforçam a atitude de cuidados excessivos que os pais têm para com seus filhos. Porém, podemos inferir que, muitas vezes, essas atitudes acabam por não favorecer o desenvolvimento e a aprendizagem deles.

Em se tratando da educação de pessoas com deficiência, as influências históricas, psíquicas e sociais corroboram para que muitos pais ${ }^{3}$ considerem que a escola especial ou instituições especializadas são o melhor local para elas estarem. $\mathrm{Na}$ pesquisa realizada por Saad (2002), encontramos declarações de mães que confirmam esta afirmação. Ela também é percebida no trabalho que realizamos com os pais no CEMEI.

Quando em nosso serviço discutimos com os pais sobre a possibilidade de seus filhos estudarem na Escola de Suplência do Município, a mãe de uma aluna com 26 anos de idade, por exemplo, nos disse:

Eu não quero que ela [a filha] estude em outra escola [escola regular], nem que faça outra atividade fora daqui [educação especial]. Aqui vocês as conhecem, entendem e sabem do que ela precisa. Além disso, aqui vocês estão sempre os olhando ... estão prestando atenção para não deixar ela sair sozinha. Em outro lugar eles não vão fazer isso. ${ }^{4}$

Acredito que a atitude de proteção excessiva leva tanto a família, como as escolas especiais, desenvolverem ações que acabam por não favorecer para que a pessoa com deficiência desenvolva habilidades e competências no cuidado de si e na tomada de decisões por si mesmo.

Piaget, Vygotsky e Wallon são importantes teóricos representantes de uma concepção construtivista ou dialética do conhecimento. Partindo de distintas questões e atribuindo diferentes posições sobre a influência do social nos processos de desenvolvimento e de aprendizagem, todos têm em comum a proposição de que a interação do sujeito com o meio é condição básica para que estes processos ocorram (LA TAILLE; OLIVEIRA; DANTAS, 1992).

\footnotetext{
${ }^{3}$ Além dos pais, profissionais ligados à área e a comunidade concordam, de um modo geral, com esta idéia.

${ }^{4}$ Esta fala consta nos registros dos atendimentos realizados nos grupos de pais dos alunos com deficiência do Departamento de Educação Especial do Município de Mauá em 1998. Este era o nome da CEMEI nesta época.
} 
A interação social pode ser compreendida como toda e qualquer forma de estabelecer relações com as pessoas e contextos vividos na sociedade, pois

[...] dependemos da natureza. Dependemos de outras pessoas, de nossa comunidade. Estamos, pois, fadados à interação, à troca. Temos que nos adaptar, regular nossas necessidades e possibilidades de sobrevivência ao que está fora de nós. (MACEDO, 2002a, p.125).

Diante deste panorama, uma das questões que me faço e faço aos profissionais da escola especial em que trabalho e aos profissionais das escolas regulares do município de Mauá em que sou referência para apoio, é a seguinte: qual é a qualidade de experiências, de situações de aprendizagem que pessoas com deficiências parecidas ou mesmo distintas - mas que no geral trazem um comprometimento em alguns aspectos físicos, mentais, psíquicos - podem ter quando estudam em grupos, isoladas dos seus pares não considerados com deficiência, para o seu desenvolvimento e sua aprendizagem, se o sujeito se desenvolve e aprende na sua interação com o meio e na troca social?

Mantoan (2000, p.61) afirma que:

[...] a baixa expectativa do meio social com relação às possibilidades do deficiente de enfrentar os desequilíbrios de toda ordem, limitam o seu nível de exigência e reduzem a sua persistência na busca das melhores soluções para resolver problemas. Com efeito, os determinantes psicossociais também influem no desenvolvimento de uma atitude crítica e a mobilização dos instrumentos intelectuais que os deficientes põem em ação para melhor ultrapassar os desafios com que se deparam nos mais diversos ambientes e situações de vida.

A autora, através dos estudos que têm desenvolvido sobre a construção das estruturas da inteligência do deficiente mental (MANTOAN, 1989, 1991) apoiada no trabalho de Inhelder ${ }^{5}$, verifica que para o sujeito aprender ele precisa entrar em contato com situações e pessoas que desencadeiem nele processos mentais, cognitivos para ativar esquemas e mobilizar recursos para agir e pensar sobre o que está vivendo. Além de Mantoan, outros pesquisadores têm desenvolvido seus estudos valorizando a interação no contexto social como fator primordial para a construção do conhecimento de crianças deficientes mentais (IDE, 1993; LUZ, 1999; MORATO, 1993; OLIVEIRA, 2000; SAAD, 2002).

Abordando o estudo sobre outras deficiências como a paralisia cerebral, Ferreira (2002), Limongi (1992), Lorenzini (1999), Sala (2003), Takatori, (1999), também

\footnotetext{
${ }^{5}$ INHELDER, B. Le Diagnostic du Raisonnement chez les Débililes Mentaux. 3. Ed. Suisse:
} Delachaux et Niestlé, 1963. 
atribuem um valor significativo à interação social e conseqüente solicitação do meio para o seu desenvolvimento e melhoria de qualidade de vida. O mesmo faz Brunello (2001) ao estudar uma criança com comprometimentos significativos no desenvolvimento mental, psíquico e social.

Voltando a problematizar o contexto escolar, questiono: quais são as experiências que favorecem o desenvolvimento da linguagem oral em uma escola em que crianças com dificuldades de articulação da fala, por exemplo, estudam com outras com as mesmas dificuldades? Como aprendemos a falar, senão ouvindo outros falarem? Como aprendemos a desenvolver nosso raciocínio, senão em contato com pessoas e situações que nos mobilizem para tal? Como sofremos o desequilíbrio necessário para desencadear nosso desenvolvimento, senão em situações que nos problematizem? A homogeneidade é o melhor contexto para favorecer o desenvolvimento e a aprendizagem?

Dadas as evidências atribuídas à importância do meio, da interação social para o desenvolvimento e à aprendizagem e, minhas experiências de trabalho atendendo pessoas com deficiência, infiro, através das questões ilustrativas colocadas, e compartilhando idéias de autores que valorizam um contexto inclusivo, de que a heterogeneidade é um fator que promove o desenvolvimento e o aprendizado do sujeito. Considero que embora não suficiente, o meio é necessário para esta promoção. Romer e Haring (1994) e Rowland (1990) ${ }^{6}$, citados por Downing (1996), afirmam que a interação entre crianças com as mesmas múltiplas deficiências, quando ocorre, é mínima. Salientam que estes alunos necessitam de referências comunicativas para possibilitar a interação social.

Estas constatações aliadas ao movimento de luta para o acesso das minorais sociais à educação, com o compromisso desta ser de qualidade para todos os alunos, evidenciam a necessidade de reestruturação dos sistemas educacionais e de uma nova perspectiva ética e política na educação. Assim, temos como emergência no cenário educacional mundial, principalmente a partir da década de noventa, a busca de uma

\footnotetext{
${ }^{6}$ ROMER, L. T.; HARING, N. G. The social participation of students with deafblindness in educacional settings. In: Education and raining in mental retardation and developmental disabilities, 29, 134-144, 1994 e ROWLAND, C. Communication in the classroom for children with dual sensory impairments: studies of teacher and child behavior. In: Augmentative and alternative comunication, 6, 262-274., 1990.
} 
escola de qualidade para todos, a busca de uma educação inclusiva. Para Mendes (2002, p.61):

A educação inclusiva é uma proposta de aplicação prática ao campo da educação de um movimento mundial, denominado de inclusão social, o qual é proposto como um novo paradigma e implica a construção de um processo bilateral no qual as pessoas excluídas e a sociedade buscam, em parceria, efetivar a equiparação de oportunidades para todos.

Segundo a Declaração de Salamanca (ONU, 1994) - principal documento que dispõe sobre os princípios de ação para a implementação mundial de uma educação inclusiva, Sassaki (1997), Mrech (www.educacaoonline.pro.br), Stainback e Stainback (1999), Mittler (2003), citando apenas dois autores nacionais e três internacionais respectivamente, entre os muitos que têm se dedicado ao tema, esta proposta educacional é baseada nos princípios de reconhecimento, valorização e investimento nas diferenças individuais.

Assim sendo, nossa hipótese é que as relações estabelecidas dentro deste contexto devem se dar a partir do investimento nas necessidades individuais de cada aluno. Neste, é dado à pessoa com deficiência a oportunidade de um novo papel social, não mais aquele de sujeito passivo, mas sim de sujeito ativo, com possibilidades de participação social, de desenvolvimento e de aprendizagem. A heterogeneidade passa a ser uma aliada neste processo na medida em que a cooperação entre os diferentes alunos, com diferentes experiências de vida, possa constituir relações de reciprocidade e interdependência que favorecerão a construção do conhecimento de todos os alunos.

$\mathrm{Na}$ Rede Municipal de Ensino de Mauá, todas as crianças de 0 a 6 anos, independentemente de suas características físicas, mentais, psíquicas, culturais e sociais, são alunas das escolas de educação infantil. Portanto, no contexto estudado tem-se a experiência de vários alunos com deficiência estudarem neste nível de ensino. No atendimento a estes alunos e seus familiares e no trabalho de apoio aos professores da rede regular municipal de ensino, verifico um consenso em considerar que estes alunos são beneficiados em seu desenvolvimento. Porém, algumas considerações feitas por pais e professores despertam-me a atenção: “Acho bom ele [aluno com deficiência] estar estudando na escola regular porque é bom para a 
socialização dele [...] eu acho que ele se desenvolveu, mas aprender mesmo, não sei se ele aprendeu" ${ }^{\prime 7}$.

Este comentário evidencia uma visão dissociada entre os processos de desenvolvimento, de aprendizagem e de socialização. Entretanto, em minha formação e experiência profissional, entendo que estes processos estão intimamente relacionados. Também percebo, no contato com os professores, que ou há uma valorização de qualquer aspecto do desenvolvimento do aluno ou ao contrário, os ganhos e os aprendizados que o aluno teve não são valorizados porque não correspondem à expectativa do professor ou porque não correspondem ao que culturalmente é esperado que o aluno aprenda na escola.

Algumas, entre as várias inquietações da vivência de todo este processo foram: Será que não podemos encontrar indícios que expressem o desenvolvimento e a aprendizagem do aluno através da valorização das relações que ele estabelece em seu cotidiano escolar? Por que e quais relações explicitam este desenvolvimento e esta aprendizagem? Como relacionar desenvolvimento, aprendizagem e socialização? Refletir ou responder a essas questões ajuda os profissionais da educação a se sentirem mais seguros para trabalhar numa perspectiva inclusiva? Como posso na função de apoio, contribuir para auxiliar este processo de construção da educação inclusiva? Não é este o caminho mais efetivo para que as pessoas com deficiência possam realizar por si mesmas atividades e tomarem decisões compatíveis com suas possibilidades? Isto não significa a construção da autonomia necessária para que eles sejam respeitados e sejam "de fato" cidadãos?

Instigados por este panorama, apresentaremos ainda na introdução deste trabalho, algumas informações importantes sobre o contexto educacional estudado, as justificativas e os objetivos deste estudo.

No capítulo dois trataremos das perspectivas teóricas que sustentaram o estudo: uma leitura construtivista de uma educação inclusiva entendida como sistema complexo $^{8}$; concepções sobre o desenvolvimento e a aprendizagem na abordagem

\footnotetext{
7 Esta fala consta nos registros de encontros realizados pela autora com professores da Rede Municipal de Mauá, que tem alunos com deficiência em sua sala de aula no ano de 1999.

${ }^{8}$ Sistema complexo é um conceito trabalhado por Macedo (1994a) e Garcia (2002) na perspectiva do construtivismo piagetiano que supõe que o processo de construção do conhecimento deve ser considerado como um conjunto de relações interdependentes. Examinaremos mais este conceito no capítulo dois, seção 2.1.1..
} 
piagetiana e seus desdobramentos para o desenvolvimento e a aprendizagem de pessoas com deficiência; concepções sobre o cotidiano e cotidiano escolar apontando a relevância de desenvolvermos pesquisas educacionais baseadas neste recorte.

No capítulo três apresentaremos a metodologia utilizada para realização deste trabalho. Iniciamos com a visão de uma pesquisa construtivista por entendermos que esta visão se enquadra dentro de uma pesquisa qualitativa baseada em estudo de casos. Seguiremos com a apresentação dos participantes da pesquisa, dos instrumentos e procedimentos utilizados para a coleta de dados e os critérios de sua organização, apresentação e discussão.

No capítulo quatro os casos estudados serão apresentados em uma narrativa que irá descrever os indícios do desenvolvimento e da aprendizagem dos alunos, para evidenciar por que e quais as relações vividas com as pessoas, espaço, tempo, objetos e atividades nos seus cotidianos escolares, contribuíram para estes processos.

O capítulo cinco destina-se à discussão dos dados. Para realizá-la, iremos articular o material empírico às perspectivas teóricas utilizadas na pesquisa.

No capítulo seis faremos nossas considerações finais após este caminho percorrido.

\subsection{Contexto educacional estudado}

Esta pesquisa foi realizada em duas escolas de educação infantil da rede municipal de educação do município de Mauá. Esta cidade pertence à região do ABCDM paulista e é a maior área de concentração industrial da região metropolitana do Estado de São Paulo. Segundo estimativa do Instituto de Geografia e Estatística IBGE, no ano de 2000 a cidade tinha 364.968 habitantes. (MAUÁ, 2002b).

A rede municipal de educação é composta por 33 escolas sendo: uma de ensino fundamental, atendendo 1895 alunos; um centro de suplência, atendendo 1507 alunos (no ensino fundamental) e 992 (no ensino médio); uma escola de educação especial com atendimento a 287 alunos e 1300 usuários; e 30 escolas que atendem as modalidades de educação infantil e de jovens e adultos. Na educação infantil tem-se 11.209 alunos com idade de quatro a seis anos atendidas em todas as unidades em 
período parcial e 1.150 alunos com idade de zero a três anos atendidas em 16 unidades em período integral. O atendimento aos jovens e adultos é oferecido em 26 unidades para 2.095 alunos. A rede conta também com cinco núcleos de educação em regiões onde não há escolas que atendem nas modalidades de educação infantil e jovens e adultos e convênio técnico - financeiro à cinco entidades nãogovernamentais para 360 crianças na modalidade de educação infantil. (MAUÁ, 2002b).

O município de Mauá conta, desde 1986, com um serviço de Educação Especial. A escolarização de alunos com deficiência até 1997 era oferecido prioritariamente na escola deste serviço que era chamado de Departamento de Educação Especial. A Secretaria Municipal de Educação, Cultura, Esportes e Lazer de Mauá - SMECE vem, desde esta data, discutindo melhores propostas de ação para garantir atenção educacional às pessoas com deficiência nesse município. Decorrente desse processo interno de reflexão da ação, o Departamento de Educação Especial vem modificando sua proposta de acordo com os princípios mundialmente apontados de inclusão social $^{9}$. Desde então, tem-se repensado as formas de escolarização destas pessoas e iniciou-se um processo rumo à construção da educação inclusiva no Município. Ao longo destes anos, várias têm sido as formas de o serviço de educação especial oferecer apoio às escolas municipais em assuntos relativos ao desenvolvimento e a aprendizagem de pessoas com deficiência. (MAUÁ, 2001a). Resumidamente estas formas foram:

$\neg 1997$ / 1998 - A equipe de educação especial de Mauá passa a fazer reflexões sobre sua estrutura de funcionamento no município e rever as propostas e as formas de atendimento oferecidas. Evidencia-se a preocupação com garantir espaços de discussão e apoio sistematizado para os profissionais da rede de educação. Os professores que recebiam os alunos com deficiência, atendidos no Departamento de Educação Especial, eram acompanhados pela equipe de apoio deste local por meio de visitas e conversas na unidade escolar por membros desta

\footnotetext{
${ }^{9}$ Conceitua-se a Inclusão Social como "o processo pelo qual a sociedade se adapta para poder incluir, em seus sistemas sociais gerais, pessoas com necessidades especiais e, simultaneamente, estas se preparam para assumir seus papéis na sociedade. A inclusão social constitui, então, um processo bilateral no qual as pessoas, ainda excluídas, e a sociedade buscam, em parceria, equacionar problemas, decidir sobre soluções e efetivar a equiparação de oportunidades para todos". (SASSAKI,1997, p. 41).
} 
equipe. Esta era composta por técnicos da área de assistência social, fisioterapia, fonoaudiologia, psicologia e terapia ocupacional ${ }^{10}$.

$\neg 1999$ - A educação infantil do município passa a ser a porta de entrada para a escolarização de todas as crianças. Manteve-se o acompanhamento dos alunos que estavam na rede e eram atendidos na educação especial e a equipe de apoio da educação especial participava das reuniões de dirigentes da educação infantil e educação de jovens e adultos.

$\neg 2000 / 2001$ - A forma de apoio foi a participação de um membro da equipe da educação especial em todos HTPCs $^{11}$ de todas as escolas. A proposta era a de que as discussões sobre educação especial e educação inclusiva permeassem as práticas cotidianas da escola.

$\neg 2002$ - Realização de oficinas com os professores da rede municipal, objetivando discutir/refletir sobre as necessidades específicas do desenvolvimento das pessoas com deficiência e/ou comportamentos típicos do desenvolvimento; valorizar a diversidade humana compreendendo que Educação Inclusiva é uma proposta de ensino de qualidade para todos os alunos; trocar conhecimentos / experiências entre os envolvidos no processo. Além das oficinas, eram oferecidos horários de agendamento para visitas e conversas com os profissionais da rede (municipal, estadual e particular) conforme a necessidade.

As mudanças ocorridas nas ações relativas à educação especial no município foram instigadas pelos princípios da SMECE: "a democratização do acesso, as condições para a permanência dos alunos na escola, gestão democrática, qualidade de ensino e valorização profissional da educação" (MAUÁ, 1999a, p.7) e perduram nos dias de hoje (MAUÁ, 2001b, 2003). Refletindo as expectativas de mudanças nos seus princípios e ações, o Departamento de Educação Especial do município passa a ser chamado de Escola Municipal de Educação Especial em 2001 (MAUÁ, 2001b) e Centro Municipal de Educação Inclusiva Cleberson da Silva em 2003 (MAUÁ, 2003).

\footnotetext{
${ }^{10}$ Esta equipe não contava com um pedagogo. Este profissional só passou a integrar este grupo em 2002. Podemos inferir, pela vivência da pesquisadora como membro desta equipe e pelos textos produzidos no departamento de educação especial (MAUÁ, 2001a), que este fato se deve a uma condição histórica da educação especial no município que estava "alicerçada numa concepção médica." (p.10).

${ }^{11}$ Os HTPCs - Horário de Trabalho Pedagógico Coletivo - são considerados como espaço de formação contínua do professor na SMECE.
} 
Os textos mais recentes da SMECE (MAUÁ, 1999a, 2001a, 2001b, 2002b, 2003), expressam a "intenção" de uma educação de qualidade para todos, e por isso inclusiva, ser construída em um processo que envolve a participação dos governantes, secretários, diretores, coordenadores, professores, equipe administrativa, equipe de apoio das escolas, técnicos, demais funcionários dos serviços de educação do município, alunos, suas famílias e comunidade.

Embora estejamos estudando escolas de uma rede municipal de educação que têm como referência em seus documentos a "intenção" de uma política educacional inclusiva, não podemos dizer que as escolas que participaram do nosso estudo têm uma estrutura, recursos materiais e humanos qualificados que permitam assegurar todos os seus princípios. Como discutiremos na seção sobre a educação inclusiva, entendemos que esta envolve um processo de construção, traz o desafio de viver em um sistema complexo, e como percebemos em nossa prática profissional e no referencial teórico sobre educação inclusiva e inclusão social utilizado, temos um longo, mas ao nosso ver possível, caminho a percorrer para que uma educação de qualidade para todos seja realidade.

\subsubsection{Justificativas ${ }^{12}$}

Constatamos, frente à nossa atual realidade educacional, a insuficiência das propostas baseadas na "lógica da exclusão"13 para garantir um ensino de qualidade a todos alunos independentemente de suas características pessoais, culturais e sociais. Temos declarações, leis e decretos que proclamam que todos os alunos devem ser matriculados preferencialmente na rede regular de ensino ${ }^{14}$. Embora ao utilizar o

\footnotetext{
${ }^{12}$ Nesta seção estaremos fazendo sínteses e agrupamentos de estudos relacionados ao tema de nossa pesquisa. Estes foram baseados em critérios que foram considerados pela pesquisadora como elo de ligação para esta justificativa. Uma vez que a leitura de um trabalho não é neutra e na organização dos dados a interpretação do pesquisador sempre está presente, pedimos licença aos autores para realizarmos as aproximações entre os estudos.

13 "Lógica da exclusão" e "lógica da inclusão" são termos desenvolvidos por Macedo (2001b) para designar modalidades de pensamentos e ações nos sistemas escolares que podem excluir ou incluir alunos. Apresentaremos em detalhes estas modalidades no capítulo dois, seção 2.1.1.

${ }^{14}$ Constituição Federal (Brasil, 1988), Constituição Estadual de São Paulo (Brasil, 1989), Lei Federal no 8069 - Estatuto da Criança e do Adolescente (Brasil, 1990), Declaração Mundial sobre Educação para Todos (WCEFA, 1990), Declaração de Salamanca (UNESCO, 1994), Lei de Diretrizes e Bases da Educação Nacional no 9394 (Brasil, 1996), Decreto no 3.298 (Brasil,1999),Lei Federal no 10.172 Plano Nacional de Educação (Brasil, 2001), Resolução CNE / CEB no 2 (Brasil, 2001).
} 
termo "preferencialmente" ainda deixam-se aberturas para justificar possíveis exclusões, estes documentos são conquistas fundamentais para a entrada no sistema educacional regular de alunos com deficiência e/ou outras características típicas do desenvolvimento. Entretanto, em concordância com Prieto (1998), não é apenas garantindo a frequiência na escola que eliminaremos suas desigualdades com uma educação de qualidade a todos os alunos.

Trabalhos como os de Angelucci (2002), Prieto (1998, 2000) e Silva (2000), demonstram a importância de estudarmos políticas educacionais relacionadas à educação especial para verificarmos como estas favorecem ou não a organização de um sistema educacional que respeite as diferentes necessidades educacionais dos alunos e como este está se organizando ou não, para atendê-las. Identificam algumas problemáticas e contradições presentes nos documentos e contextos estudados e apontam, de formas gerais, que estas necessidades não estão sendo consideradas. Podemos inferir que estes dados refletem uma política que de fato ainda não se traduz em práticas inclusivas.

A referência da política educacional é fundamental para a efetivação de uma prática inclusiva. Além dela, outros fatores influenciam no sentido positivo ou negativo para tal prática. Abaixo, apresentaremos algumas produções acadêmicas (dissertações e teses) realizadas direta ou indiretamente sobre o tema da educação inclusiva $^{15}$. Acreditamos que estas pesquisas podem oferecer indícios dos fatores envolvidos nesta temática e dos estudos que ainda necessitam serem realizados.

Vários trabalhos partem da representação, do entendimento, da aceitação e das práticas pedagógicas dos professores com relação aos alunos com deficiência / diferentes / com necessidades educacionais especiais ${ }^{16}$, para discutir direta ou indiretamente as problemáticas e as necessidades para uma prática inclusiva. Entre eles podemos citar: Beraldo (1999), Buffa (2002), Castro (2002), Cordeiro (2003),

\footnotetext{
${ }^{15} \mathrm{O}$ objetivo desta pesquisa não foi realizar um levantamento minucioso dos trabalhos realizados sobre a proposta de Educação Inclusiva. Entretanto, consideramos relevante para o presente estudo, fazer um levantamento geral sobre as tendências de pesquisas realizadas nos últimos anos para justificar a coerência e relevância de nosso estudo. As informações relativas aos trabalhos produzidos na Universidade Federal de São Carlos e na Pontifícia Universidade Católica de São Paulo foram retiradas via resumo publicado nos sites das Universidades. Sugerimos para os interessados em obter mais informações sobre as tendências nas produções acadêmicas relacionadas à Educação Especial, Integração Escolar e Educação Inclusiva, consultar os trabalhos de Damiani (2001) e Nunes et al (1998).

${ }^{16}$ Os trabalhos variam bastante com relação a nomenclatura utilizada.
} 
Faleiros (2001), Medeiros (2002), Moraes (2002), Ross (2000), Souza (2002), Vizim (1997). O que todas estas pesquisas têm em comum é terem professores de escolas regulares como sujeitos do estudo. As metodologias e os objetivos dos trabalhos foram específicos para cada realidade. As necessidades apontadas frente às dificuldades encontradas foram relacionadas à melhoria das políticas-educacionais, ao suporte para os professores no que se refere a disponibilização de serviços de apoio a prática pedagógica - incluindo recursos e materiais necessários. A formação direcionada para informações sobre as necessidades especiais dos alunos e à reflexão sobre suas práticas profissionais, considerando as dimensões racionais e afetivas, também estão presentes nas conclusões dos estudos. Bastos (2003) demonstrou a possibilidade de um trabalho de escuta psicanalítica dos professores para proporcionar novas formas de ensino e de aprendizagem para tornar possível um trabalho de inclusão escolar de crianças com dificuldades.

Caiado (2002) e Sala (2003) estudaram a trajetória de vida de alunos cegos e uma aluna com paralisia cerebral, respectivamente, verificando os desafios vividos pelos sujeitos e seus familiares na busca da vivência escolar inclusiva. Ambos valorizam a escola como contexto de imersão nas relações sociais e de acesso a conhecimentos específicos para a construção de atitudes críticas. Estas histórias demonstraram a necessidade de um investimento familiar constante para o acesso aos serviços adequados para o apoio a escolaridade dos alunos e os grandes enfrentamentos necessários nos âmbitos sociais e educacionais para a conquista da cidadania destes sujeitos.

O cotidiano escolar e os diferentes sujeitos envolvidos neste cotidiano, tais como professores de classes especiais, professores, funcionários, dirigentes, pais e alunos de escolas regulares, bem como profissionais da saúde e equipe de direção de ensino, foram contexto e participantes de pesquisas recentes. Entre elas destacamos as realizadas por Ferreira (2002), Jordão (2001), Machado (2003), Mattos (2000), Picchi (1999), Santos (2002), Sekkel (2003), Yazlle (2001). A articulação de maneiras diferenciadas da ou sobre a visão de todos estes envolvidos no contex to do cotidiano é o ponto de interseção destes estudos. Eles se pautam no entendimento que a reflexão sobre um contexto inclusivo e os meios para efetivação desta prática deve se dar dentro de "cadeias de significância", "rede de significações" ou, 
simplesmente "redes". Isto é, a inclusão escolar / a educação inclusiva / a educação para todos para ser compreendida e efetivada é necessário considerar os múltiplos fatores envolvidos no processo de exclusão e segregação das "diferenças" e “diferentes". A criação de políticas educacionais baseadas em (re) construções coletivas e democráticas dos projetos educacionais são fundamentais. Estes estudos utilizaram-se de metodologia qualitativa na coleta e análise dos dados.

Localizamos um grupo de trabalhos que adotaram a metodologia de estudos de caso para estudarem a inclusão na escola de alunos com necessidades educacionais especiais. Verificaram os benefícios e/ou dificuldades desta proposta considerando principalmente a qualidade de interação destes alunos entre seus pares e professores. Estas pesquisas utilizaram o "ambiente natural" / o "dia-a-dia" / o "cotidiano" como contexto de estudo. Entre eles estão: Aranha (1991), Costa (2002), Dechichi (2001), Duarte (1990), Odeh (1998) e Watanabe (2002). Esta última autora também procurou verificar como estava sendo avaliado o desempenho da aluna nas tarefas solicitadas.

Os estudos de Andretto (2001) e Ide (1993) foram os que mais procuraram avaliar a processo de inclusão considerando, respectivamente, as potencialidades pedagógicas do aluno estudado e da construção de conhecimento nos alunos com deficiência ${ }^{17}$.

Guirado (2001) estudou a contribuição da fisioterapia na inserção escolar de uma criança com atraso no desenvolvimento neuropsicomotor. Sacaloski (2002) realizou um estudo comparativo entre o desempenho dos alunos ouvintes e alunos com deficiência auditiva no ensino regular e pesquisou a visão dos pais, professores e alunos neste contexto. Estes estudos foram desenvolvidos no município de Mauá e foram iniciativas de pesquisar a educação inclusiva no município no qual o presente trabalho foi desenvolvido.

Através destes estudos e frente a complexidade da atual realidade educacional brasileira, constatamos a extrema necessidade de aprofundarmos estudos na perspectiva da educação inclusiva. Várias são as possibilidades de pesquisa neste tema.

\footnotetext{
${ }^{17}$ Capellini (2001) objetivou avaliar a inclusão escolar com base no rendimento escolar utilizando-se de teste de avaliação, questionário sobre desempenho escolar e boletim acadêmico. A metodologia deste trabalho não foi baseado em estudo de caso e não teve o cotidiano como contexto de avaliação.
} 
Para nossa satisfação, ao realizar este breve levantamento bibliográfico, percebemos uma tendência nas produções recentes em estudar as implicações no/do cotidiano e a multiplicidade de fatores e sujeitos envolvidos no contexto escolar que pretende ser inclusivo.

Apesar das iniciativas destes trabalhos, percebemos que este ainda é um terreno que precisa gerar muitos frutos na contribuição para propostas educacionais inclusivas.

Temos dimensão da complexidade e dos desafios que a mudança para uma "lógica da inclusão" nos impõe. Assim sendo, acreditamos ser de extrema necessidade nos debruçarmos sobre o estudo de realidades que, inicialmente no plano da intencionalidade, se propõem a trabalhar nesta vertente.

A nossa pesquisa se justifica pelas indagações colocadas na apresentação deste trabalho, do referencial teórico estudado e das problematizações colocadas nas produções recentes. A seguir, detalharemos os fatores que mobilizaram nosso recorte de pesquisa.

Ainda é recente e pouco estudado os benefícios de um contexto escolar que pretende ser inclusivo para o desenvolvimento e à aprendizagem de crianças com deficiência valorizando as relações estabelecidas com as pessoas, com o espaço, com o tempo, com os objetos e com as atividades do cotidiano escolar nestes processos. Isto é, percebemos a necessidade de enfocar quais são os ganhos que as crianças com deficiência têm no seu desenvolvimento e na sua aprendizagem quando inseridas num contexto escolar regular que respeite e invista nas suas possibilidades de desenvolvimento e de aprendizagem e por que e quais são as relações que favorecem estes processos. Entendemos que socialização não é desvinculada do desenvolvimento e da aprendizagem. Para nós, tratar desarticuladamente estes termos, é não considerar nenhuma destas dimensões na sua essência. Dito de outra maneira, para teóricos construtivistas ou dialéticos como Piaget, Vygotsky e Wallon, a construção do conhecimento, o desenvolvimento e a aprendizagem se dão pela possibilidade de interação social que toda pessoa vai estabelecendo ao longo de sua vida. Portanto, se dissemos que a pessoa se "socializou", devemos necessariamente localizar uma mudança no seu desenvolvimento e perceber algo novo que foi aprendido. E, se dissemos que a pessoa se socializou, mas não aprendeu, devemos 
questionar que processo de socialização foi este. Neste sentido, questionamos qualquer discurso e prática que se baseiam numa concepção dissociada destes processos. E, também, daqueles que consideram que a mera inserção na classe comum já é um trabalho de inclusão escolar. Mendes (2002, p. 74) indica a falta de estudos sobre este ângulo da inclusão escolar e diz:

A esse respeito, é comum ouvirmos que na inclusão o importante é favorecer a socialização da criança com necessidades educacionais especiais, sendo seus desempenho escolar irrelevante! Seria o caso de questionar que tipo de socialização traria uma situação que nega o acesso ao currículo. A socialização no papel de deficiente, de incapaz e inútil? Que mudança isso traria ao que já está estabelecido?

Prieto (2002, p. 57) adverte à necessidade de questionarmos se as ações educacionais do poder público "têm garantido a aprendizagem de alunos com necessidades educacionais especiais ou apenas propiciado espaço de convívio social."

Esta autora coloca uma preocupação que permeou os questionamentos no nosso estudo e nos mobilizou à elaboração de um roteiro de observação do aluno no cotidiano escolar que foi utilizado como instrumento de coleta de dados e intervenção para subsidiar a prática da escola na observação, intervenção e avaliação dos alunos ${ }^{18}$. Segundo esta autora:

Cabe ressaltar que não é suficiente usar como indicadores apenas os dados oficiais de evasão e repetência escolar e tampouco informações sobre a aceitação (ou diminuição das reclamações) do aluno por parte do professor e colegas. É imprescindível a criação de instrumentos que avaliem a aprendizagem dos alunos e sinalizem as mudanças que devem ser implantadas para garantir educação para todos. (PRIETO, 2002, p.57).

Entendemos que a observação da relação do aluno com os diversos elementos que compõem o cotidiano escolar tais como, a relação com as pessoas, com o espaço, como o tempo, com os objetos e com as atividades podem expressar o seu desenvolvimento e a sua aprendizagem e sinalizar as mudanças que devemos implementar em favor de uma prática inclusiva.

Nas tendências presentes nos trabalhos citados acima e nos autores que têm abordado diretamente o tema de pesquisa no/do cotidiano (ANDRÉ, 1989; GARCIA, 2003; SATO, SOUZA, 2001) percebemos o quanto esta dimensão é de extrema relevância para as reflexões e práticas na área educacional. Acreditamos que pela

\footnotetext{
${ }^{18}$ Detalharemos o objetivo deste roteiro bem como a forma que ele foi utilizado em nosso estudo no capítulo três, seção 3.3..
} 
observação e analise dos pormenores, dos fatos muitas vezes neglicenciáveis do cotidiano, podemos encontrar indícios significativos sobre as questões problematizadas (GINZBURG, 1989). Em nosso caso o propósito é encontrar indícios do desenvolvimento e da aprendizagem dos alunos. Consideramos que se reduzirmos os nossos olhares para aquilo que é mais evidente e valorizado nas formas padronizadas de avaliação, será difícil considerar as singularidades dos alunos e, muito provavelmente, não valorizaremos suas possibilidades de desenvolvimento e de aprendizagem. Portanto, realizar estudos que se proponham a analisar as relações no cotidiano escolar, buscando sinais, pistas e indícios, é fundamental.

Nesta pesquisa optamos por buscar estas sinalizações que demonstram ou não o desenvolvimento e a aprendizagem dos alunos em escolas de educação infantil. Entendemos que os primeiros seis anos de vida de toda pessoa é um período de intensa mudança nos aspectos de maturação, de construção cognitiva, de constituição psíquica e de elaboração de atitudes, conceitos e valores individuais e sociais. Portanto, não podemos considerar que estes primeiros anos e a educação nesta etapa da vida sejam apenas uma "preparação" para a entrada no mundo da aprendizagem e uma "espera" para entrada no mundo adulto. Se recorrermos a estudos sobre a importância da dimensão lúdica, do brincar e do jogo é evidenciado a riqueza para o desenvolvimento e à aprendizagem desta fase da vida ${ }^{19}$.

Segundo a Lei de Diretrizes e Bases da Educação - LDB (Brasil, 1996) a educação infantil é a porta de entrada no sistema de educação. Portanto, acreditamos ser direito de todas as pessoas, independente de suas condições físicas, mentais, psíquicas e culturais, terem acesso e oportunidades efetivas para seu desenvolvimento e sua aprendizagem neste início de escolarização em contextos regulares. Como dito na apresentação deste trabalho, questionamos a qualidade de possibilidades de interação que as pessoas podem ter em contextos especiais. A segregação que na maioria dos casos se faz presente nestes contextos, colabora para o descrédito individual e social para as pessoas que não foram aceitas pelo contexto regular.

\footnotetext{
${ }^{19}$ Os trabalhos de Kishimoto (1999), Macedo (1994b, 2003) e Oliveira (1998) apresentam importantes contribuições para a justificativa apresentada.
} 
Mantoan (1998) comenta que há sistemas organizacionais de ensino que tornam a trajetória escolar muito difícil para alguns alunos. Segundo a autora,

[...] um desses sistemas, que muito apropriadamente se denomina 'de cascata' prevê a exclusão de algumas crianças, que têm déficits temporários ou permanentes e em função dos quais têm dificuldades para aprender. Esse sistema contrapõem-se à melhoria do ensino nas escolas, pois mantém ativo o ensino especial, que atende aos alunos que caíram na cascata, por não conseguirem corresponder às exigências e expectativas da escola regular. Para se evitar a queda na cascata, na maioria das vezes um caminho sem volta, é preciso remar contra a correnteza, ou seja, enfrentar os desafios da inclusão (p.44).

Neste sentido, entendemos que a educação infantil no sistema regular de ensino é fundamental para garantir o início no percurso educacional com qualidade e, assim, evitar que o aluno "desça correnteza abaixo".

Consideramos ser importante verificar os ganhos no desenvolvimento a na aprendizagem de crianças com deficiência que pretende ser inclusivo independente do tipo de déficit apresentado pelo aluno. Isto é, queremos constatar as contribuições da educação inclusiva para qualquer pessoa independente do déficit que ela tem. Portanto, temos como participantes de nossa pesquisa, dois alunos com diferentes tipos de deficiência. Um aluno com paralisia cerebral e outro aluno com síndrome de Down.

Com estas considerações iniciais apresentamos justificativas para a relevância do presente estudo, bem como da escolha dos recortes realizados. Na seqüência iremos focalizar os objetivos gerais e específicos deste trabalho.

\subsection{Objetivos}

Esta pesquisa se apóia em duas premissas básicas. A primeira é que o ensino regular pode ser um contexto favorável ao desenvolvimento e à aprendizagem de alunos com deficiência se for adotada uma perspectiva de educação inclusiva, como sugerem as políticas educacionais e os trabalhos relacionados ao tema. A segunda é que as relações da criança com pessoas, atividades, objetos, espaço e tempo no cotidiano escolar propiciam seu desenvolvimento e sua aprendizagem, em uma visão construtivista do conhecimento.

Baseados nessas premissas, formulamos as hipóteses de que ao observarmos cuidadosamente as relações da criança no cotidiano escolar encontramos indícios 
sobre o progresso de sua aprendizagem e, conseqüentemente, sobre as relações que mais contribuem para isso.

A partir destas hipóteses, esta pesquisa tem como objetivo geral:

$\neg$ Estudar por que e quais as relações estabelecidas no cotidiano escolar podem beneficiar o desenvolvimento e a aprendizagem de alunos com deficiência em uma perspectiva inclusiva de educação e quais foram os progressos desses alunos neste contexto.

E, como objetivos específicos:

$\neg$ Ressaltar a importância de se utilizar instrumentos de observação e registro que possibilitem atentar para as sutilezas das relações estabelecidas no cotidiano com pessoas, tempo, espaço, objetos e atividades, uma vez que estas relações são indicadores para observação, intervenção e avaliação no trabalho que favoreça a construção de conhecimentos no aluno.

$\neg$ Discutir uma proposta de educação inclusiva fundamentada em pressupostos construtivistas.

$\neg$ Analisar alguns desafios apresentados em um contexto educacional que busca respeitar e valorizar as diferenças individuais dos alunos, em um processo que tem como norte a educação inclusiva. 


\section{PERSPECTIVAS TEÓRICAS}

\subsection{Educação inclusiva}

Para apresentar as idéias sobre educação inclusiva, que são a base de sustentação da proposição e discussão desta pesquisa, recorro às experiências de formação e prática profissional que me aproximaram desta proposta de concepção e atuação no contexto educacional.

Não faço uma apresentação das origens históricas, legislações, princípios e fundamentos relacionados ao movimento para uma educação inclusiva. Considero que este caminho não traria uma contribuição significativa para a pesquisa, pois, muitos autores e produções acadêmicas recentes já o realizaram com muita propriedade. Sugiro ao leitor interessado neste caminho, que consulte os trabalhos de: Aranha (2001), Baumel e Semeghini (1998), Bueno (1993, 2001, www.educacaoonline.pro.br), Carvalho, R. E. (1997, 1998, 2000a, 200b), Downing (1996), Ferreira (2002), Machado (2003), Mantoan (1989, 1991, 1997, 1998, 2000, 2001), Mazzotta (1996), Mendes (2002), Mittler (2003), Mrech (www.educacaoonline.pro.br), Saad (2002), Santos (2000), Sassaki (1997), Stainback e Stainback (1999), Stobäus e Mosquera (2003), Werneck (1997, 1999), Yazlle (2001), os documentos legais: Constituição Federal (Brasil, 1988), Constituição Estadual de São Paulo (Brasil, 1989), Lei Federal no 8069 - Estatuto da Criança e do Adolescente (Brasil, 1990), Declaração Mundial sobre Educação para Todos (WCEFA, 1990), Declaração de Salamanca (UNESCO, 1994), Lei de Diretrizes e Bases da Educação Nacional no 9394 (Brasil, 1996), Decreto no 3.298 (Brasil,1999), Lei Federal nº 10.172 - Plano Nacional de Educação (Brasil, 2000), Resolução CNE / CEB no 2 (Brasil, 2001), a revista Pátio (2002) e o site Educação on-line (http://www.educacaoonline.pro.br.). Estes autores, documentos e fontes de 
dados foram e são para mim, importantes referências para a compreensão deste complexo processo de construção de uma educação de qualidade para todos.

O que desenvolvo neste texto, é a colaboração que a leitura de uma abordagem construtivista pode trazer para compreensão dos fundamentos, dos princípios e dos desafios implicados na construção desta qualidade de educação. Penso que essa é uma contribuição nova nas pesquisas, e que foi subsídio em meu percurso na pósgraduação. A intenção é procurar estabelecer um diálogo com algumas concepções construtivistas piagetianas e enfatizar a perspectiva de construção para uma proposta de educação inclusiva. Assumindo o risco das articulações indevidas, escrevo este item em primeira pessoa do singular e generalizo em primeira do plural quando faço inferências coletivas.

Utilizo, muitas vezes durante este texto, o termo Educação de Qualidade para Todos como sinônimo de Educação Inclusiva pois, entendo que se trabalharmos por uma educação inclusiva, proporcionaremos uma educação de qualidade para todos. Deixo grifadas as palavras, conceitos, idéias e termos - chaves nesta discussão para ressaltar a importância destes para a construção de uma prática inclusiva de educação.

\subsubsection{Educação inclusiva: uma leitura construtivista}

Ao iniciar a orientação com o Prof. Dr. Lino de Macedo no ano de 2001, ele me apresentou o texto "Fundamentos para uma Educação Inclusiva" (MACEDO, 2001b) que acabara de escrever. Neste, o professor utiliza para discutir o tema da Educação Inclusiva, concepções teóricas de Jean Piaget e Rolando Garcia. Ao ler o texto, percebo uma forma diferenciada, porém, baseada em princípios e fundamentos comuns de todas as abordagens teóricas e discussões que eu já havia participado. Este texto, seguido de outros momentos de estudo no período da pós-graduação, propiciaram-me uma leitura construtivista sobre a proposta da Educação Inclusiva.

Utilizo como referência para esta apresentar esta leitura, o referido texto, o seminário ministrado pelo Prof. Dr. Lino de Macedo ao seu grupo de orientandos sobre o tema "Pesquisa em uma visão construtivista" em 2001, o seu curso oferecido no Instituto de Psicologia da USP, na disciplina de pós-graduação intitulada " $O$ 
possível e o necessário em Piaget e sua contribuição para à aprendizagem escolar”, e outros textos relevantes nesta discussão.

As idéias, termos e conceitos apresentados relacionam-se a benefícios e ou desafios ora para o próprio aluno, ora para os demais alunos, ora para os professores, ora para a comunidade escolar, ora para todo o sistema educacional. Estas relações podem e devem ser, na medida do possível, realizadas de forma combinada. Entretanto, utilizo apenas alguns exemplos dos benefícios e ou desafios no decorrer do texto .

Para pensar em uma escola que seja de qualidade para todos e por / para isso, inclusiva, Macedo (2001b) propõe que temos que repensar o modo de funcionamento institucional baseado em uma lógica de exclusão em favor de outro baseado na lógica da inclusão.

Este autor, no texto elaborado em co-autoria com Amaro (www.educacaoonline.pro.br, p. 1). afirma que a lógica da exclusão apóia - se na lógica das classes.

Ou seja, por relações em que os termos são reunidos por atenderem a um critério comum (obter certas notas, expressar certas formas de conduta, aceitar certo contrato institucional, apresentar certas características físicas, intelectuais, etc.), que iguala as pessoas e que exclui (pela indiferença, reprovação, crítica) os que não se encaixam nessa referência, perpetuando e conservando as desigualdades sociais. Nessa lógica, as pessoas ou coisas são reunidas por uma classificação simples, do tipo sim ou não, que torna as partes, que compõe o todo, equivalentes entre si, ou seja, substituíveis por apresentarem tais características comuns. As partes não equivalentes são abandonadas, excluídas, isto é, ficam sem lugar no sistema.

Se pensarmos na organização da escola operando nesta lógica, percebemos a não possibilidade de participação das pessoas com deficiência. Estas, evidenciam a diferença, a não equivalência, a não possibilidade de classificações simples por terem aspectos físicos e/ou cognitivos que não atendem a critérios comuns da "maioria" dos alunos. Entendo que as pessoas com deficiência, na discussão atual da educação inclusiva, são o "bode expiatório" do sistema. Elas personificam a exclusão de tantas outras pessoas pela não possibilidade de oferecer uma educação de qualidade em um contexto em que se pretende igualar os alunos por critérios comuns. Assim, se pensarmos que ao final de um ano letivo todos os alunos terão que atingir o mesmo nível de desenvolvimento e de aprendizagem, provavelmente não valorizemos no que cada aluno com deficiência - ou outro que não atingiu este nível esperado - progrediu nestes termos. 
Para construirmos uma concepção e prática educativa que mude esta visão precisamos nos pautar na lógica da inclusão.

Nessa lógica, os termos são considerados em suas singularidades e pelas múltiplas relações que podem ser estabelecidas entre eles, dependendo do critério que se utiliza. Assim, os termos ou partes valem pelas diferentes posições que podem ocupar no sistema e são simultaneamente pelo que são e pelo que se tornam no contexto dessas relações. Nesta forma de lógica, as relações são de diferença (sendo a diferença nula uma delas), de singularidade e, portanto, por uma definição que considera indissociavelmente o indivíduo e o contexto, com as múltiplas posições que pode nele ocupar dependendo do sentido ou direção que orienta as relações entre os elementos que compõem o sistema. (AMARO; MACEDO, www.educacaoonline.pro.br, p. 1)

Entendo que operar nesta lógica é a possibilidade que temos em oferecer uma educação de qualidade para todos e oferecer concretas possibilidades de participação e benefício para os alunos com deficiência.

Uma educação que opera nesta lógica irá considerar que o aluno com deficiência é um sujeito singular. Isto é, que tem características físicas, cognitivas, desejos, sentimentos, expectativas, formas de entendimento do mundo que lhe são próprias. Esta singularidade foi e é construída nas relações estabelecidas com seu próprio corpo, com as pessoas, objetos, espaços, tempos, atividades que realizou e realiza em sua vida.

$\mathrm{Na}$ lógica inclusiva o aluno é valorizado em suas diferenças e nas formas com que estabelece as relações no contexto em que está inserido. $O$ aluno pode demonstrar seu conhecimento e utilizar-se de recursos diferenciados para sua construção. Um aluno que não fala e não sabe escrever, por exemplo, pode se comunicar através de expressões corporais, gestos, movimentos. Podemos avaliar como está se dando a construção do conhecimento deste aluno através das várias formas com que ele se relaciona com o que é vivenciado na escola e não só pelo produto final de suas atividades. Podemos avaliar o desenvolvimento e a aprendizagem do aluno a partir do progresso por ele apresentado com relação aos objetivos traçados na identificação de suas necessidades. Isto é, valorizamos o que ele progrediu a partir de suas possibilidades de desenvolvimento e de aprendizagem. O que se espera que ele desenvolva e aprenda é estabelecido considerando sua singularidade e não naquilo que é esperado para a maioria.

Ao mesmo tempo, a lógica inclusiva possibilita que as relações também sejam de semelhança, dependendo da posição na relação que se considera. Exemplificando, 
as crianças com deficiência são alunas como as que não tem deficiência, podem ou não ter pai, mãe, irmãos, cachorros, gostar de jogar bola, ver TV, saber contar, conhecer sobre animais, e tantas outras coisas, como outras crianças também podem. Dito de outra maneira, na lógica inclusiva a semelhança não é negada, uma vez que ela é uma constatação possível em determinadas relações. Porém, a diferença é valorizada como possibilidade nas relações.

Relação é um conceito fundamental nesta leitura construtivista. Para Macedo (2001b, p. 35), "relacionar é definir algo em relação ao outro, pela sua posição ou lugar, por aquilo que está entre os dois, não nele ou no outro". Esta é uma visão importante porque permite que o aluno possa ser compreendido nas relações. $\mathrm{O}$ aluno não tem características definidas a priori, mas sim, no contexto da relação em que está envolvido. O aluno é mais ágil ou menos ágil que outro aluno dependendo do contexto, da atividade na qual estamos observando a relação. $\mathrm{O}$ aluno pode ser mais ágil do que ele mesmo foi ontem. As referências são múltiplas e simultâneas.

Pensar e praticar um raciocínio relacional e inclusivo impõe que tenhamos que nos implicar como um dos elementos presentes na rede de relações que se estabelece no contexto educacional. Não podemos dizer que o aluno não está aprendendo ou não tem condições de desenvolver tais atividades, sem questionarmos as estratégias de ensino, os recursos que viabilizamos, o que estamos conceituando como aprendizado, quais são nossas expectativas em relação a este, entre outras questões. Isto é, "incluir significa abrir-se para o que o outro é e para o que eu sou ou não sou em relação ao outro. Por isso, a educação inclusiva supõe, sobretudo, uma mudança em nós, nos nossos trabalhos...” (MACEDO, 2001b, p. 35).

Uma das mudanças que considero ser um dos desafios para uma educação inclusiva é passar de uma visão da co-dependência para a visão da interdependência. Estas são duas formas de estabelecermos relações entre as pessoas que Macedo (2001b) utilizou para compreender as relações estabelecidas numa lógica de exclusão e numa lógica de inclusão, respectivamente.

A co-dependência é um termo trazido da sociologia por Giddens (1993) ao observar relações em que uma pessoa necessita que a outra precise de seus cuidados. Assim, a pessoa que cuida julga ter a necessidade constante de cuidar do outro, tornando-se assim, dependente daquele de quem cuida. Por exemplo, os pais de uma 
criança com deficiência podem considerar que seus filhos são dependentes de seus cuidados para sempre para sobreviverem. Desta forma eles se tornam dependentes do filho, estabelecendo entre eles uma relação de co-dependência. Neste tipo de relação a dependência mútua não permite o desenvolvimento da autonomia em ambas as partes. Se o professor de um aluno com deficiência estabelece com ele uma relação deste tipo, provavelmente ele atuará julgando que, em função desta deficiência, o aluno é incapaz de desenvolver determinadas habilidades e, por isso, necessitará constantemente do cuidado dele, que é o único e o mais responsável pelo trabalho com o aluno. Neste tipo de relação será difícil que o aluno desenvolva recursos próprios para aprender a cuidar de si, se adaptar a novas situações e consequentemente desenvolver autonomia, considerando suas limitações, mas sobretudo, a partir do investimento em suas possibilidades de aprendizagem.

A diferença entre co-dependência e interdependência é sutil na medida em que em ambas a dependência esta presente na relação. Porém, na primeira a dependência é assimétrica. A posição de um dos termos da relação é suposta como superior a do outro. A relação é de subordinação. Na segunda, há correspondência entre o valor dos termos, a relação é de coordenação. A outra diferença fundamental é que no primeiro tipo de relação a dependência se mantém constantemente, um termo é "refém" do outro, apesar daquele que se julga na posição superior se considerar como "livre" do outro. Na relação de interdependência, a dependência objetiva a autonomia para os dois termos da relação. Segundo Macedo (2002a, p. 124)

Interdependência significa ser parte e todo ao mesmo tempo. Isso é o mesmo que autonomia. Como ser relacional, uma parte nossa estará sempre no outro, daí o trabalho de assimilação. Ao mesmo tempo, o outro não pode fazer por nós. Em outras palavras, não fazemos nada sozinhos, mas ninguém pode fazer por nós. Autonomia significa um aperfeiçoamento e construção do que ninguém poderia fazer por nós e simultaneamente um reconhecimento e aprofundamento do que contamos com o outro. [grifos nosso].

A construção da autonomia é um dos importantes objetivos para uma educação de qualidade. Esta é almejada para uma educação inclusiva e deve se desenvolver nas relações entre os diversos sujeitos que compõe o contexto educacional: alunos, professores, pais, agentes escolares, dirigentes, coordenadores, supervisores, secretários de educação entre outros.

Autonomia nesta perspectiva significa podermos pensar, julgar e agir com responsabilidade e comprometimento considerando o conjunto de uma situação, os 
diversos pontos de vista e coordenando com os nossos. Este é um aprendizado fundamental. Porém, ele é muito difícil na medida em que normalmente pensamos, agimos e tomamos decisões apenas considerando o que para nós é melhor. Ou, em outros momentos, parece que não temos opinião nenhuma sobre determinada situação e quem pode pensar, agir e tomar decisões é um outro.

Quando observamos o cotidiano de uma escola que tem o desafio de incluir alunos, percebemos com freqüência esta situação. Por exemplo, o que o professor "supõe" que o aluno deva aprender é um determinado conceito X. Se este aluno por algum motivo não o aprende, ou o problema é do aluno, e por isso ele não pode acompanhar aquele grupo, ou é preciso de outra pessoa para dizer ao professor o que e como este aluno pode aprender. Em uma situação como esta, dentro da perspectiva de construção de autonomia, o que o aluno pode e deve aprender deveria ser uma decisão compartilhada por todos os envolvidos no processo na perspectiva da interdependência.

A visão da interdependência é muito interessante na medida em que explicita que nossas relações humanas deveriam ser complementares, indissociáveis e irredutíveis. Sobre estes termos Macedo (2001b, p.36-38) afirma:

A complementaridade é o princípio pelo qual, num todo, a parte que falta para a outra parte virar todo é complementar [...] significa que há uma parte que nos completa e que está fora de nós. É isso que quer dizer interação e assimilação, na teoria de Piaget. O que quer dizer assimilação? Por que somos fadados à interação? Interação quer dizer relação. Porque o nosso sistema respiratório precisa do ar e nós não fabricamos o ar. Por isso, assimilar significa poder incorporar do outro aquela parte sem a qual eu não sou, eu não me completo.

[...] Ser indissociável significa que, na relação, não existe a não-dualidade, não existe o separado ou separável [...] a indissociabilidade é o princípio pelo qual compartilhamos um mesmo todo, ainda que eventualmente em posições diferentes. Ou seja, pertencemos todos a um mesmo contínuo, mesmo quando negamos esse contínuo, mesmo querendo sair fora dele, mesmo tendo medo dele [...] Na relação, nos limites do sistema que está sendo considerado (família, escola, etc.) estamos sempre dentro, compondo as partes que definem o sistema como um todo.

[...] Outro aspecto da relação é o da irredutibilidade. Numa relação, nada é redutível porque tudo depende da relação, que se estabelece entre uma coisa e outra. Por exemplo, simultaneamente, se em uma relação algo é menor, em outra pode ser maior e em outra ainda pode ser igual. Por isso, na relação, o princípio é o da irredutibilidade, pois um objeto não se reduz ao nosso referente, ele admite múltiplos referentes, ou seja, pode ser compreendido de muitas formas [...] $\mathrm{Na}$ lógica da relação, somos irredutíveis no sentido de que não somos reduzidos a uma coisa ou outra porque quem nos define é a relação. [grifos nosso].

Estas características de uma relação de interdependência são muito oportunas para pensarmos as qualidades das relações favoráveis a uma educação inclusiva. 
O aluno em um contexto inclusivo é irredutível. Ele não "é" lento, não "é" terrível, não "é" difícil para aprender. Ele não se reduz a uma coisa. O aluno em relação a alguma atividade, pessoa, conhecimento pode se manifestar de diferentes maneiras.

O aluno não "é" do professor. Este aluno faz parte de um mesmo todo - o sistema educacional - e cada um tem uma posição diferente em relação a ele. Por isso, ele é indissociável.

As ações educacionais realizadas pelos diferentes profissionais na educação são complementares. As ações do diretor, pais, auxiliares administrativos, merendeira, vigia, professor, alunos e do próprio aluno em questão se complementam para o seu processo de aprendizagem.

Estes princípios e fundamentos inicialmente apresentados são também algumas das características de um sistema complexo. Este termo é um conceito trabalhado por Garcia (2002) e Macedo (1994a) a partir do referencial teórico de Jean Piaget. Ele se refere a uma forma de conceber a construção do conhecimento, tanto em nível individual, como em nível social, que compreende o sistema como uma totalidade com propriedades interdependentes. Este sistema é

[...] constituído por processos determinados pela confluência de fatores que interagem de tal maneira que não se pode separá-los. Em conseqüência, o sistema não pode ser descrito adequadamente nem seu funcionamento explicado, pela mera adição de enfoques parciais provenientes de estudos independentes de cada um dos seus componentes. (GARCIA, 2002, p. 55).

No sistema complexo os elementos ou subsistemas que o compõe estão interdefinidos. Como um sistema não-decomponível, os diferentes componentes só podem ser definidos em função do resto.

Pode-se dizer que para promover a educação de crianças, jovens e adultos, necessita-se de um sistema educacional. Isto é, os alunos, a família, a comunidade, as atividades culturais, a escola, as secretarias de educação, os órgãos e conselhos federais, estaduais e municipais de educação, a sociedade civil organizada em favor da educação devem compor um todo coordenado entre si, constituindo um todo relacionado, um sistema.

No entendimento de que para uma proposta de educação inclusiva seja efetivada, devemos compreender esta rede que compõe o sistema educacional, considero que esta proposta de educação pode ser vista como um sistema complexo. 
Ao discutirmos sobre estes conceitos no percurso da pós-graduação, fui estabelecendo articulações possíveis entre os termos Educação Inclusiva e Sistema Complexo.

É com a intenção de acrescentar elementos para a problematização e vislumbrar possibilidades de construção de uma educação inclusiva que prossigo com outras características típicas deste sistema que, ao meu ver, são princípios para uma educação inclusiva. Em outras palavras, a Educação Inclusiva pode ver vista como um Sistema Complexo porque considera que as relações entre todos os elementos envolvidos no sistema educacional - quer sejam os alunos, os profissionais da educação, a estrutura política-educacional, a estrutura física e material das escolas, a estrutura familiar, cultural e social dos alunos e da comunidade - são interdependentes e, por isso, complementares, indissociáveis e irredutíveis. Além disso, a Educação Inclusiva tem outras características comuns a um Sistema Complexo tal como veremos adiante.

O Sistema Complexo é um sistema construído e aberto a todas as possibilidades dependendo do que, para quem e por que determinada ação e / ou recurso são necessários. O movimento dialético presente nos processos de construção são valorizados. Quando pensamos nos recursos didáticos favoráveis ao aprendizado dos alunos, podemos entender que dependendo do objetivo que se pretende alcançar e com qual aluno, podemos elaborar diferentes estratégias. Exemplificando: podemos realizar uma atividade de dramatização quando esta estratégia favorecer com que os alunos se aproximem e elaborem um conceito. Este não necessariamente tem que ser apresentado para o aluno através da forma tradicional: o professor explica, o aluno presta atenção e depois compreende o conceito. Esta, entretanto, pode ser uma forma, desde que, para determinado aluno, seja uma estratégia pertinente em determinado momento. Outro exemplo: o aluno pode ser avaliado pela sua expressão verbal, pelos seus gestos, pelo que digita numa tela de computador e não necessariamente pela sua escrita. Na Escola Inclusiva podemos ter alunos que por alguma razão não têm condições de se expressar através deste recurso, por isso é possível criarmos outras formas de expressão. Outro exemplo: o objetivo do trabalho com um aluno pode ser diferente do objetivo com outro aluno desde que seja para contribuir no seu processo 
de desenvolvimento. Este objetivo vai sendo percebido e construído na interação do aluno no contex to escolar.

No Sistema complexo devemos, dependendo da interpretação ou compreensão dos aspectos envolvidos em uma determinada situação, considerar os múltiplos fatores envolvidos, as múltiplas singularidades presentes e também nas combinatórias possíveis para refletirmos e agirmos diante dela. Por que o aluno não pára na sala? Por que o aluno não desenha? Por que o aluno só se comunica com a família e não com o professor ou colegas? Por que o aluno repete uma mesma atitude o tempo todo? Por que o aluno não consegue assimilar o conteúdo da aula? Por que o aluno não se interessa por nada do que oferecemos para ele? Só podemos ter suposições dos fatores envolvidos nos padrões apresentados pelo aluno, se realizarmos uma leitura compreensiva das situações e da singularidade de cada aluno. Isto é, não tem a princípio, uma única razão pela qual o aluno faz ou não faz determinada atividade. Precisamos observar as relações que ele estabelece com os vários elementos que compõe sua realidade educacional para termos indícios destes fatores, e assim, intervir a favor de seu desenvolvimento e do seu aprendizado. Precisamos valorizar a singularidade e integrá-lo no contexto geral para uma dimensão compreensiva do aluno e de suas ações. Dito de outra maneira, precisamos articular a parte com o todo, o individual e o genérico como sugere Heller (1989), para termos as necessidades do sujeito articuladas numa dimensão social.

Uma mesma situação pode ser lida de diferentes maneiras dependendo do recorte que é dado e /ou de quem a observa. Em função disso a interdisciplinaridade é valorizada. A situação é melhor compreendida quanto mais pudermos articular os diferentes olhares e perspectivas.

O sutil, o relativo, a interpretação são elementos importantes. Pelo exame dos pormenores, dos fatos muitas vezes negligenciados, podemos encontrar elementos que nos aproximam da singularidade do sujeito e dos fatores envolvidos em determinada situação (GINZBURG, 1989).

Tal como o sistema complexo, uma educação inclusiva expressa-se por um dinamismo dialético. Ela é uma educação viva que tem que se atualizar constantemente. $\mathrm{O}$ ontem faz parte do hoje, mas já não é mais o mesmo. Ele foi 
modificado pelas necessidades encontradas sem, entretanto, ter que perder sua essência uma vez que ela foi útil para determinado fim.

Pressupõe a dimensão coletiva (o outro é parte do processo), a reciprocidade (a troca mútua entre os elementos envolvidos), a solidariedade (a consistência presente nas relações permite que cada sujeito pense e atue em seu favor e em favor do próximo simultaneamente, pois compreendem que fazem parte de um mesmo todo), a cooperação (operar junto, ao mesmo tempo em favor de um fim).

Quando estamos em uma escola em que as ações se pautam num raciocínio inclusivo, qualquer que seja a posição e função do sujeito dentro deste sistema, a ação deste é considerada como parte do processo que é o norte do projeto pedagógico e político da escola. Por isso, as ações realizadas por qualquer sujeito (quer seja o aluno, a família, o professor, o vigia, o diretor) estão em favor de um compromisso coletivo.

A reciprocidade, a solidariedade e a cooperação devem ser exercidas no cotidiano por se compreender que o que eu faço por outro beneficia-me, direta ou indiretamente. Quando um aluno auxilia o outro na realização de uma tarefa escolar, ele põe em funcionamento seus esquemas de ação. Estes esquemas se atualizam e podem se reorganizar em outro nível de desenvolvimento. Os três termos em destaques são indicadores para Piaget (1932/1994) da evolução cognitiva da criança. Para este autor: "só a cooperação leva à autonomia." (p. 299).

Em se tratando do desenvolvimento de ações de reciprocidade, solidariedade e cooperação, entendo que este é um desafio fundamental para todos os envolvidos em um sistema complexo / em um sistema educacional / em uma educação inclusiva. Temos que desenvolver e exercitar, tal como as crianças, estas formas de relação.

Piaget (1981/1985, 1976/1987) observando a construção cognitiva da criança, percebeu condições necessárias, pseudonecessárias, possíveis e impossíveis para que tal processo ocorra. Macedo ${ }^{20}$ examina estas condições dentro de um sistema complexo, independente de sua natureza. Para este autor o necessário é o básico no

\footnotetext{
${ }^{20}$ As considerações de Macedo nos próximos parágrafos estão baseadas na discussão realizada no seu curso oferecido no Instituto de Psicologia da USP, na disciplina de pós-graduação intitulada "O possível e o necessário em Piaget e sua contribuição para a aprendizagem escolar", 2001. Os textos de referência utilizados na disciplina estão indicados no corpo do texto.
} 
sistema para sua existência, é a coluna dorsal, é o que integra e o torna coerente. $\mathrm{O}$ pseudonecessário é o falso necessário, é aquilo que se julga como fundamental no sistema, mas na realidade não o é. Porém, muitas vezes, descobrimos que aquilo que julgávamos necessário é pseudonecessário com o desenrolar histórico. Porque, numa fase prévia, o pseudonecessário parecia necessário. Temos o pseudonecessário quando não se consegue construir e vislumbrar os possíveis do sistema. O possível são as múltiplas possibilidades que podem ser manifestadas num sistema, é o repertório, o que diferencia; o impossível é o que não pode ser num sistema, é fonte de abertura, cria-se pela impossibilidade do contrário.

Podemos questionar o que seria em uma educação inclusiva estas condições. Aqui seguem algumas hipóteses:

Será que a singularidade de cada aluno, de cada contexto e realidade, deve ser olhada e descrita se caracterizando como o necessário deste sistema? E, as diferenças devem ser valorizadas e utilizadas para a construção dos possíveis? Será que o pseudonecessário são aquelas reivindicações que muitas vezes são feitas para evitar que tenhamos que mobilizar nossos recursos próprios para resolução dos problemas e dificuldades inerentes a um sistema complexo? E, o impossível seria a não possibilidade de termos uma qualidade inclusiva de educação dentro do atual sistema de educação e, por isso, traz a abertura para a criação de um novo sistema?

Macedo, também numa leitura de elaborações teóricas de Piaget (1967/2000) entende que em um sistema o necessário é obtido a partir de recorrências e o possível a partir de extrapolações. Selecionando algumas acepções do dicionário eletrônico Houaiss (2001), recorrer pode ser compreendido como "examinar (algo) minuciosamente; esquadrinhar, investigar; trazer à lembrança, à imaginação; recordar; pedir auxílio a (alguém); lançar mão de, servir-se de; empregar, usar.” E, extrapolar como "generalizar com base em dados parciais ou reduzidos; estender a validade de uma afirmação ou conclusão além dos limites em que ela é comprovável; exceder; ultrapassar os limites."

Voltando às questões propostas acima, se o necessário for a singularidade do aluno, precisamos recorrer a ele, através da nossa convivência, observação, exame minucioso de suas relações no contexto escolar para compreendermos esta singularidade. Tudo aquilo que já conhecemos deve ser utilizado nesta compreensão. 
Se os possíveis podem ser construídos a partir das diferenças dos alunos, precisamos extrapolar, exceder os limites do conhecido, generalizar a partir daquilo que já conhecemos, ampliar nossas ações para que a diferença seja valorizada, encontre meios de ser explicitada e seja um elemento que favoreça o progresso dos envolvidos.

Os elementos apresentados e as "extrapolações" que realizei, a partir da referência teórica construtivista piagetiana, deram-se em função de considerar que pensar e viver em sociedade, pensar e construir uma educação inclusiva é o desafio de viver em um sistema complexo.

A Educação Inclusiva, a Educação de Qualidade a Todos não foi pensada e praticada no antigo e vigente sistema educacional. Portanto, como criaremos um novo sistema que atenda aos fundamentos e princípios desta educação que almejamos? Se ainda não é possível a criação de um outro sistema, como criaremos possibilidades neste sistema que temos? Ao criarmos estas possibilidades não estaremos automaticamente e paulatinamente construindo um novo sistema?

Estas questões expressam a minha visão de que ainda não podemos afirmar que estamos vivendo uma prática educacional inclusiva se considerarmos todos os seus princípios e fundamentos. Entretanto, acredito que na medida em que formos criando possibilidades dentro do sistema atual, poderemos transformar e construir um novo sistema. Por isso, apesar dos inúmeros desafios, não acredito que a educação inclusiva seja utopia, mas é um sonho que se sonharmos juntos poderá se tornar realidade.

Antes de terminar este item, quero acrescentar algumas outras considerações para a discussão sobre uma educação inclusiva que também permearam a orientação desta pesquisa.

Um primeiro ponto a destacar é que embora o objetivo desta pesquisa seja estudar por que e quais as relações estabelecidas no cotidiano escolar podem beneficiar o desenvolvimento e a aprendizagem de alunos com deficiência em uma perspectiva inclusiva de educação, a compreensão dos princípios, fundamentos e desafios para uma educação com esta qualidade é válido para todos os alunos independentes de suas características físicas, mentais, psíquicas, culturais e sociais. Percebo que o fato da terminologia: Educação Inclusiva, ter se difundido a partir da 
Conferência Mundial de Educação Especial em Salamanca (ONU, 1994) colaborou para que as pessoas associem a idéia de educação inclusiva à educação de pessoas com deficiência ou necessidades educacionais especiais. Considero fundamental colaborarmos para mudar esta associação por três motivos principais. Primeiro porque enquanto centralizarmos a atenção nestas pessoas, o ônus desta proposta recairá sobre elas e ainda poderemos esquecer dos demais alunos que também compõem o cenário educacional. Temos que ter todos os alunos incluídos e não somente os com algum tipo de deficiência ou necessidades educacionais especiais. Segundo, porque o movimento por uma educação inclusiva (em seus princípios e não em sua terminologia) é anterior a citada Conferência. Mrech (www.educacaoonline.pro.br) localiza as origens históricas deste movimento no entroncamento de quatro fontes básicas: a emergência da psicanálise, a luta pelos direitos humanos, a pedagogia institucional e o movimento de desinstitucionalização manicomial. Terceiro porque temos muitas discussões teóricas atuais que nos falam em favor de uma pedagogia diferenciada (ALCUDIA et al, 2002; ANDRÉ, 2002; MACEDO, em fase de elaboração, PERRENOUD, 2000a). Esta pedagogia compartilha princípios, fundamentos e desafios comuns a uma pedagogia inclusiva. A base dela é garantir que encontremos situações ótimas de aprendizagem para a diversidade de alunos que compõe a sala de aula. Para que isto ocorra, os autores citados propõem uma forma diferenciada de conceber o ensino e a aprendizagem, bem como a organização do tempo, espaço e relações na escola.

Uma das importantes contribuições que a proposta da pedagogia diferenciada traz é termos o desenvolvimento de competências e habilidades como um dos objetivos da prática educativa. Na escola seletiva, baseada na lógica da exclusão, as competências e habilidades eram pré-requisitos para a entrada do aluno na escola. Elas eram condições necessárias, como ponto de partida, para que o aluno tivesse a aquisição dos conteúdos disciplinares. $\mathrm{Na}$ escola para todos, baseada na lógica da inclusão e que utiliza-se de uma pedagogia diferenciada, os conteúdos disciplinares são meios no processo de construção de conhecimento o que implica em ter como um de seus objetivos, o desenvolvimento de habilidades e competências. (MACEDO, em fase de elaboração). 
Para Perrenoud (2000b) competência é tomar decisões num contexto em que você tem que mobilizar recursos, ativar esquemas para agir ou interpretar determinada situação. Para Macedo (em fase de elaboração) competência é saber mobilizar recursos afetivos e cognitivos em determinadas circunstâncias em favor de algo que vale a pena. É a habilidade de lidarmos com questões conflitivas.

Habilidade (MACEDO, em fase de elaboração) é desenvolver determinados esquemas que permitem ao sujeito realizar determinadas ações. Ex: habilidade de andar, habilidade de falar, habilidade de contar, habilidade de pensar, habilidade de ler, entre outras. Para agir com competência temos que coordenar nossas habilidades em função da necessidade apresentada.

Entendo que desenvolver habilidades e competências permite-nos construir conhecimentos e utilizá-los nos momentos adequados de nossas vidas. A habilidade de comunicarmo-nos e a habilidade de compreender determinado aspecto da realidade, quando coordenados, pode permitir-nos a aquisição de um conhecimento, por exemplo.

Agir com competência no sentido apresentado é fundamental para o desenvolvimento de uma prática inclusiva. Assim como, agir na urgência, decidir na incerteza (MACEDO, 2001a) e cultivar uma prática reflexiva (MACEDO, 2002b).

Entendendo a escola como um sistema complexo, em que temos que coordenar as diferenças, as semelhanças, as ocorrências simultâneas, agir na urgência é:

[...] o desafio de realizarmos, na escola, o mesmo que fazem um bom cirurgião ou cozinheiro: agem agora, não antes ou depois; agem de modo preciso, conforme as necessidades (isto é, rápido, lento, muito, pouco e todas suas combinações), e determinado na direção daquilo que querem alcançar [...] valorizar o instante, no sentido de mobilizar nossos melhores recursos (saberes) em favor de metas ou propósitos educacionais. É certo que, depois, podemos retomar e refletir sobre nossas decisões, compartilhar soluções com nossos colegas, rever nossos erros, completar informações, compreender melhor os meios que utilizamos. (MACEDO, 2001, p. vi,vii)

Neste sistema complexo também temos que decidir na incerteza. Diante da multiplicidade de fatores envolvidos nos acontecimentos do cotidiano escolar não temos como ter certeza do que nos leva a tomar determinada decisão. Não temos o controle da efetividade de nossas ações. "Decidir na incerteza é saber mobilizar recursos, atualizar esquemas, tomar decisões no momento em que as coisas se realizam e sabendo que às vezes é no sutil ou pequeno que algo grande se realiza."(MACEDO, 2001, p. viii). 
Diante desta realidade, uma condição essencial para termos uma prática consciente e promotora do desenvolvimento e da aprendizagem das pessoas, numa perspectiva inclusiva, é desenvolvermos uma prática reflexiva.

Para Macedo (2002b), prática reflexiva refere-se à prática e a reflexão compondo um mesmo todo de forma interdependente e, por isso, complementares, indissociáveis e irredutíveis. Diz respeito a praticar a reflexão sobre a ação já realizada e sobre a que será realizada. Consideramos que assumir o desafio da prática reflexiva é um outro princípio fundamental na formação e prática profissional de todos aqueles que buscam uma escola de qualidade para todos.

Os princípios, fundamentos, desafios e considerações apresentadas sobre educação inclusiva em uma leitura construtivista, auxiliaram-me a compreender, no percurso desta pesquisa, necessidades e possibilidades na construção de uma educação inclusiva. Porém, não é possível desenvolver de forma minuciosa as idéias, termos e conceitos abordados porque fazer isso implicaria num novo recorte de pesquisa.

Minha intenção é trazer elementos novos para a discussão e compreensão de um contexto educacional inclusivo e apontar algumas idéias que fazem parte da interpretação realizada nesta pesquisa.

\subsection{Desenvolvimento e aprendizagem}

Falar de desenvolvimento e de aprendizagem implica considerar o processo de construção do conhecimento e do desenvolvimento da inteligência. Por isso, para realizar o presente estudo recorremos a concepções teóricas que buscam compreender como se dão estes complexos processos nos seres humanos. A perspectiva teórica construtivista piagetiana / teoria da assimilação $o^{21}$ foi adotada porque é, ao nosso ver, coerente com os princípios para uma educação inclusiva. E, porque, ao considerar o desenvolvimento e o conhecimento como processos de construção, assegura-nos a possibilidade de que todas as pessoas podem aprender.

\footnotetext{
${ }^{21}$ Nos textos: O nascimento da inteligência na criança (Piaget, 1936/1987) e A questão da Inteligência: todos podem aprender? (Macedo, 2002a), são apresentadas outras formas de se compreender o funcionamento da inteligência. São elas: concepção Intelectualista Vitalista / Inatismo, Empirista Associonista / Empirismo, Apriorismo e a psicologia da forma e a Teoria das tentativas.
} 
A premissa básica da teoria da assimilação é que desde os primórdios da vida do bebê a inteligência vai sendo construída num processo contínuo de interação entre o sujeito e o meio externo. Considera que o sujeito tem uma estrutura orgânica herdada ou adquirida ao nascer e que esta vai sendo reorganizada e desenvolvida na sua relação com os elementos que compõem o seu universo. Esta premissa levou-nos a escolher esta concepção teórica - e outras relacionadas a ela - como base para o nosso estudo.

Os nossos caracteres genéticos e biológicos influenciam naquilo que seremos no futuro, assim como, as experiências, vivências e oportunidades que temos na vida durante a interação com o meio. Portanto, estes fatores estão relacionados de forma interdependente para o desenvolvimento de nossa inteligência. Isto é, ao considerar o desenvolvimento como resultado de uma interação contínua do sujeito com o meio, a visão construtivista piagetiana, expressa um caráter de interdependência entre os fatores envolvidos no desenvolvimento, que só pode acontecer na interação, nas relações que estabelecemos. Deixamos de considerar um pólo como sendo a causa e o outro, a consequiência e passamos a compreendê-los nas suas relações de complementaridade, irredutibilidade e indissociabilidade.

Para Piaget e Inhelder (1968/1999), o desenvolvimento, a evolução mental é resultado da maturação, experiência, interação social e equilibração, sendo que esta última coordena os demais.

A maturação do complexo formado pelo sistema nervoso e pelos sistemas endócrinos e o crescimento orgânico são, em seu conjunto, o primeiro fator necessário para o desenvolvimento. Entretanto, Piaget e Inhelder (1968/1999) lembram que ainda conhecemos mal os pormenores das condições maturacionais que possibilitam a constituição das estruturas operatórias. Segundo os autores, a maturação abre possibilidades para novas condutas, mas não é condição suficiente. Para as possibilidades abertas realizarem-se a maturação tem que ser acrescentada de "um exercício funcional e de um mínimo de experiência." (p.132, grifo dos autores). Além disso, quando mais se afastam do período sensório-motor, mais cresce a importância do meio físico ou social.

O segundo fator é o exercício, a experiência adquirida na ação efetuada sobre os objetos. A experiência pode ser física e lógico-matemática. As duas experiências 
consistem em agir sobre os objetos. Porém, a primeira é para abstrair as propriedades dos objetos e a segunda é para conhecer o resultado da coordenação das ações. Isto é, conhecer não aquilo que pertence aos objetos, mas sim aquilo que está entre eles, na sua relação. Um exemplo da experiência física é a criança comparar o peso de dois objetos independentemente dos volumes. Da experiência lógico-matemática, seria quando a criança descobre empiricamente que a soma de um conjunto é independente da ordem espacial dos elementos ou de sua enumeração. (PIAGET; INHELDER, 1968/1999).

As interações sociais constituem o terceiro fator para o desenvolvimento mental. A socialização é vista como uma estruturação na qual o sujeito tanto contribui quando recebe. "A ação social é ineficaz sem a assimilação ativa da criança, o que supõe instrumentos operatórios adequados.” (p.134). Porém, sem a interação social não há possibilidade de estabelecimento de operações e cooperações entre o sujeito e o meio.

Ao descrever estes três fatores, Piaget e Inhelder enfatizam que todos são insuficientes por si sós para a evolução mental. Reafirmam que a explicação do desenvolvimento deve levar em conta as dimensões ontogenética e social simultaneamente. Os autores consideram ser necessária a existência de um mecanismo interno para coordenar estes fatores. Este mecanismo consiste no quarto fator para o desenvolvimento e é conhecido como o processo de equilibração. Este processo auto-regula as sequiências de compensações ativas do sujeito em resposta às perturbações exteriores. Isto é, mediante as perturbações provocadas pela interação com o meio o sujeito tem que mobilizar os seus esquemas de ação e/ou do pensamento para compensar estas perturbações e oferecer respostas adaptativas a elas. Ao fazer isso, o sujeito, em um movimento espiral, evolui para um novo ponto no seu processo de desenvolvimento.

A teoria psicogenética de Jean Piaget, investigando a origem e a evolução da inteligência humana, elaborou alguns enunciados centrais para a compreensão do processo de desenvolvimento. Resumiremos a seguir, alguns destes enunciados ${ }^{22}$.

\footnotetext{
${ }^{22}$ Os textos de referência que utilizamos são: O nascimento da inteligência (PIAGET, 1936/1987), A construção do real na criança (PIAGET, 1937/2001), A psicologia da criança (PIAGET; INHELDER, 1968/1999) e Ensaios construtivistas (MACEDO, 1994b). A disciplina "A construção cognitiva, moral e cultural do si mesmo" cursada no Instituto de Psicologia - USP, 2002, contribuiu, também, para a compreensão destes enunciados.
} 
O bebê nasce com certos fatores hereditários ou condições orgânicas adquiridas que são a base do desenvolvimento intelectual. Sobre esta base, serão construídas, através da ação do sujeito sobre o meio, esquemas que possibilitarão a continuidade de sua interação com este. Neste processo o meio vai sendo incorporado ao sujeito através da assimilação e o sujeito vai transformando frente a este meio seus esquemas para se ajustar às demandas no processo denominado de acomodação. É no equilíbrio entre assimilação e acomodação que o sujeito se adapta às exigências do meio, organizando para tal seus esquemas em favor de tal adaptação. Os esquemas são as formas de ação utilizadas pelo sujeito para realizar as trocas com o meio. O andar é um esquema motor, por exemplo. Através da equilibração processo interno que mobiliza os sistemas de ação e pensamento para compensar as perturbações produzidas pela troca do sujeito com o meio - se estabelece um novo ponto de partida para a seqüência do processo evolutivo.

É neste movimento evolutivo que as estruturas cognitivas são desenvolvidas. Piaget divide o desenvolvimento cognitivo em estádios e subestádios que são caracterizados "por uma estrutura de conjunto em função da qual se explicam as principais reações particulares." (PIAGET; INHELDER, 1968/1999, p.131). O autor considera que os estádios têm um caráter universal, pois todos os seres humanos passam pela mesma ordem na seqüência evolutiva. A aquisição desta seqüência ocorre em tempos distintos para cada sujeito. As estruturas de cada estádio são sucessivas e integrativas. O que foi adquirido em um estádio integra-se e reconstrói no seguinte novos esquemas e conseqüentes estruturas a partir das interações com o meio.

O estádio do desenvolvimento sensório-motor refere-se a uma estrutura de inteligência baseada nos aspectos sensoriais e motores da criança do 0 a 2 anos aproximadamente ${ }^{23}$. Segundo Macedo (1994b, p. 124),

\begin{abstract}
caracteriza-se pela construção de esquemas de ação que possibilitam à criança assimilar objetos e pessoas. Além disso, é também marcado pela construção prática das noções de objeto, espaço, causalidade e tempo, necessárias à acomodação (ajustamento) desses esquemas aos objetos e pessoas com os quais interage. Tem-se aí um processo de adaptação funcional pelo qual a criança regula suas ações em função das demandas de interação, compensando progressivamente, sempre no
\end{abstract}

\footnotetext{
${ }^{23}$ Reforça-se que toda vez que Piaget exemplifica com idades cronológicas ele está se referindo ao tempo médio observado nos seres humanos para aquisição de determinadas estruturas. Porém, ele enfatiza que este tempo depende de cada criança e do contexto social no qual está inserido.
} 
plano das sensações e da motricidade, as perturbações produzidas pela insuficiência dos esquemas no processo de interação.

A ação sobre os objetos tem uma função central neste período para a criação da primeira estrutura do desenvolvimento que é a do grupo de deslocamentos. Esta estrutura permite que a existência dos objetos não esteja condicionada a sua visibilidade. Isto é, a criança sabe e admite que o objeto existe mesmo sem o estar vendo. Percebe que o objeto permanece mesmo quando os deslocamentos sofridos por este são invisíveis. Neste período ela se percebe como um dos objetos do universo (PIAGET, 1937/2001). A inteligência sensória-motora é a matriz de outras inteligências que serão posteriormente construídas e reconstruídas a partir dela.

Dos dois anos até os doze anos, aproximadamente, temos o estádio $d a$ inteligência simbólica ou representativa. Este estádio se subdivide em préoperatório (até os sete anos) e operatório concreto (dos sete aos doze). Neste grande período, a criança adquire a capacidade de representar um objeto ou acontecimento através de uma palavra, gesto, lembrança. A função simbólica é o que possibilita esta representação (MACEDO, 1994b). Neste período observamos a presença da representação e da linguagem paralelamente a melhora progressiva da inteligência manifestada no plano da ação. A criança vai adquirindo a capacidade de realizar operações lógico-matemáticas (por exemplo, é capaz de saber que a soma de dois fatores independe de sua ordem), de compreender a reversibilidade dos objetos e das ações (por exemplo, a quantidade de um líquido não se altera quando mudamos de recipiente) e de iniciar um raciocínio dedutivo.

Mais uma vez, as estruturas adquiridas neste período organizam-se e integram-se para preparar e possibilitar o terceiro e último grande período: o das operações formais. Este inicia aos doze anos e será a estrutura básica ao longo de toda a vida adulta. É caracterizado pelo raciocínio hipotético-dedutivo que possibilita que o sujeito realize operações no plano verbal e do discurso, sem necessitar do plano concreto. Neste período o sujeito tende a adquirir uma certa estabilidade em suas estruturas. Estas estão abertas a novas aquisições/procedimentos/aprendizagens.

Para Piaget (1937/2001), desde os primeiros meses de vida, o bebê desenvolve operações intelectuais construídas a partir de sua ação sobre o universo. Inicialmente este é caótico e, progressivamente, a criança vai desenvolvendo a capacidade de nele se situar. Esta "elaboração do universo" ou "construção do real na criança" tal como 
nomeia o autor, ocorre à medida que a criança vai se relacionando com os elementos que compõem este universo: objetos, espaço, tempo e as relações de causalidade. Isto é, paulatinamente o bebê se perceberá como um dos objetos do universo. Os objetos são entendidos tanto como objetos físicos, quanto como objetos humanos (pessoas). Eles estão situados em um determinado espaço (não existe objeto que não resida em lugar nenhum), num determinado tempo (o objeto existe no passado, presente e/ou futuro), e estão submetidos a uma causalidade, a uma implicação (uma intervenção no objeto, causa no sentido de implicação, uma reação no objeto).

Essas considerações teóricas permitem crer que nossas ações devem ser contextualizadas a partir destes elementos. Portanto, não se pode falar de desenvolvimento e de aprendizagem sem considerar as relações que o sujeito estabelece com ele mesmo, com as pessoas com quem convive, com as atividades que desenvolve, num espaço e tempo específicos.

Piaget, ao estudar as origens do conhecimento, como se dá o nascimento da inteligência e a construção do real na criança, "interessou-se muito mais em descrever e analisar o desenvolvimento da criança do que suas aprendizagens." (MACEDO, 1994b, p. 123). Entretanto, trouxe significativas contribuições para a compreensão dos processos de desenvolvimento e de aprendizagem na medida que os relaciona dialética e interdependentemente. No texto "Aprendizagem e conhecimento", Piaget (1957/1974) apresenta considerações importantes sobre estes processos.

Para este autor, podemos falar em aprendizagem senso strito e aprendizagem senso lato. Aprendizagem senso strito é aquela em as aquisições se desenvolvem no tempo em função da experiência mediata. Isto é, a experiência baseada na relação entre dois elementos, quer sejam eles pessoas ou objetos. As experiências podem ser físicas ou lógico-matemáticas. As primeiras referem-se àquelas a partir das quais ao agir sobre os objetos, abstraímos suas propriedades, como por exemplo, ao brincar com carrinhos, as crianças podem dizer que eles são azuis, vermelhos, de madeira, de ferro, com portas que abrem e fecham. As segundas são aquelas em que ao agir sobre os objetos abstraímos propriedades que não estão nos objetos, mas que são deduzidas a partir de um processo lógico, da coordenação das ações, das relações estabelecidas entre os objetos. Por exemplo, se dissermos para uma criança que brinca com cinco 
carrinhos que iremos pegar dois para nós, ela poderá deduzir que restará para ela três carrinhos.

A aprendizagem senso latu engloba a aprendizagem senso strito e se confunde com desenvolvimento (PIAGET, 1959/1974). As aquisições desta aprendizagem não dependem da experiência. Elas são aquisições evolutivas dadas pela reorganização interna das estruturas do sujeito pela necessidade das exigências de equilíbrio entre os processos de assimilação e acomodação. $\mathrm{O}$ processo de equilibração garante a possibilidade de realizar raciocínios dedutivos que não estão mais necessariamente ligados à experiência.

Para Macedo (1994b, p. 132) a aprendizagem senso latu (desenvolvimento) diz respeito a "construção de estruturas físicas ou mentais que possibilitam a construção de conhecimentos, que são da ordem do universal." As estruturas estão relacionadas às formas de organização e reorganização interna que possibilitam o desenvolvimento operatório. E, a aprendizagem senso strito são aquisições da ordem do particular, do domínio de determinados procedimentos. O que é da ordem do estrutural está encarnado na ordem do particular. O particular colabora na construção do estrutural. Quando uma criança aprende a engatinhar, por exemplo, ela adquiriu um novo procedimento para sua locomoção. Este procedimento só pôde ser adquirido em função de uma estrutura que o sustentou. Na evolução do sujeito esta aquisição de engatinhar propulsiona novas reorganizações internas e a conseqüente mudança nas suas estruturas internas. Torres (2001, p.11) comentando a relação entre desenvolvimento e aprendizagem afirma:

\footnotetext{
Desenvolvimento e aprendizagem acontecem de maneira dialética, de modo que, para aprender algo novo, uma criança, interagindo com seu meio, necessita ter minimamente esquemas já desenvolvidos para poder incorporar uma nova aprendizagem; por outro lado, essa nova aprendizagem, para acontecer, desencadeia a transformação dos esquemas anteriores, levando a criança a um novo patamar de desenvolvimento.
}

Recentemente, Macedo (2003) ao analisar a importância da dimensão lúdica nos processos de aprendizagem escolar como uma das condições para o desenvolvimento das crianças, apresentou interessantes compressões sobre o significado e relações entre desenvolvimento e aprendizagem, também numa visão construtivista piagetiana. 
Para ele, desenvolvimento e aprendizagem estão relacionados de forma interdependente e expressam duas fontes de conhecimento. Uma endógena e outra exógena, respectivamente. Desenvolver refere-se ao processo construtivo que ao voltar-se para algo interno ao sujeito, possibilita a sua amplificação. E, apreender refere-se à incorporação de algo externo que se torna individual ou coletivo.

A criança desenvolve brincadeiras e aprende jogos. Pode também aprender brincadeiras com seus pares ou cultura e, com isso, desenvolver habilidades, sentimentos ou pensamentos. O mesmo ocorre nos jogos: ao aprendê-los desenvolvemos o respeito mútuo (modos de se relacionar entre iguais), o saber compartilhar uma tarefa ou desafio em um contexto de regras e objetivos, a reciprocidade, estratégias para o enfrentamento das situações-problema, raciocínios. (MACEDO, 2003, p. 3).

Macedo (2003) considera desenvolvimento e aprendizagem como formas interdependentes de conhecimento, sendo por isso indissociáveis (desenvolvimento e aprendizagem estão sempre associados), irredutíveis (porque desenvolvimento não se reduz à aprendizagem e aprendizagem não se reduz à desenvolvimento) e complementares (um necessita de outro para que o conhecimento seja construído).

A respeito de relações entre aprendizagem e desenvolvimento, Piaget no prefácio do livro "Aprendizagem e estruturas do conhecimento" (PIAGET, 1974/1977) refere que nas experiências de aprendizagem podemos obter três espécies de efeito em conformidade com as linhas de desenvolvimento em que a criança se encontra. $\mathrm{O}$ primeiro diz respeito a um efeito nulo. As experiências não provocam nem perturbação e nem progresso nas aquisições desejadas. Isso acontece "quando a criança é muito jovem e que não há ainda para ela, ligação entre as zonas de assimilações relativas ao fator introduzido [na experiência que a criança passa] e a reação esperada" (p.10). O segundo é um efeito positivo que se dá quando a experiência provoca uma aceleração que antecipa progressos que sem ela demoraria mais tempo para ocorrer. Neste caso a experiência/ intervenção/fator introduzido constitui um instrumento de assimilação pela criança. $\mathrm{O}$ terceiro é quando o fator introduzido pela experiência tem um efeito negativo momentâneo, mas que pode ser superado lentamente ou rapidamente pela criança. Esta perturbação necessita de uma acomodação compensadora que poderá ou não ser realizada dependendo da possibilidade de superação do conflito que a experiência lhe provocou. Isso pode ocorrer porque a zona de assimilação está delimitada às possibilidades estruturais do desenvolvimento de cada pessoa. Para Piaget (1974/1977 p. 11), 
[...] todas as modificações obtidas consistem, no momento em que se produziram, em acelerações do desenvolvimento ou em conflitos, de início perturbadores (tendo mesmo possibilidades de regressões momentâneas ou ocasionais) e depois formadores de novas aquisições, mas em conformidade com as linhas (ou créodes) do desenvolvimento.

Consideramos este estudo significativo, pois, muitas vezes, deparamos-nos com situações em que nossas intervenções parecem não ter o efeito de desencadear uma aprendizagem no aluno, ou ainda observamos uma regressão. Por isso, este estudo fornece-nos alguns elementos para a compreensão destes acontecimentos.

Os conceitos de defasagens em extensão e defasagens em compreensão (PIAGET, 1937/2001) são também úteis para a compreensão de regressões que eventualmente parecem ocorrer nos processos de desenvolvimento e de aprendizagem. A primeira defasagem pode ser observada quando dentro de um mesmo período evolutivo, período sensório-motor por exemplo, em presença de um problema novo para a criança, ela se depara com os processos primordiais de adaptação. Isto é, este novo problema faz com que a criança tenha que passar por necessidades de assimilação e acomodação que necessitaram se equilibrar para que ela possa se adaptar e solucionar o novo problema. A segunda defasagem refere-se à necessidade que a criança tem de reconstruir em um novo e superior plano de desenvolvimento, conquistas anteriormente realizadas no plano inferior. Por exemplo, a criança terá que no período pré-operatório desenvolver no plano representacional a capacidade de se situar e situar o outro no espaço. No período sensório-motor esta conquista já havia sido realizada no plano da ação. Porém, neste novo patamar do desenvolvimento, tem que desenvolver novas formas/estruturas para que esta representação possa ocorrer.

Uma última consideração ainda se faz necessária neste momento do texto. A partir da leitura dos estudos de Piaget, de seus colaboradores e estudiosos, compreendemos que os conhecimentos são construídos na relação que o sujeito (com suas características próprias) estabelece com as pessoas, com o espaço, com o tempo, com os objetos e com as atividades que realiza. Para compreendermos melhor esta idéia, citamos alguns exemplos: a criança constrói o conhecimento sobre o que é mão, pé, barriga, nariz, pai, mãe, irmãos, amigos, professor, relacionando-se com o seu próprio corpo e com as pessoas com quem convive; ela adquire o conhecimento sobre o que é perto, longe, encima, embaixo, metros, quilômetros na sua constante 
relação com os espaços em que está submersa; os conceitos de antes, depois, presente, passado, futuro, minutos, horas, são construídos porque ela vive se reportando ao agora, ao ontem, ao amanhã; é através das relações com os objetos que ela vai construindo os conceitos de grande, pequeno, pesado, leve, redondo, quadrado, muito, pouco; é durante todas as atividades que realiza que estas relações são colocadas em funcionamento de forma interdependente. Isto é, as atividades são realizadas por pessoas, em um determinado espaço e tempo, com determinados objetos. Portanto, os conhecimentos podem ser construídos nas relações com os elementos que apontamos, vivenciados no nosso cotidiano nas relações com as atividades.

Muitos são os aspectos envolvidos nos processos de desenvolvimento e de aprendizagem na perspectiva construtivista. Deixamos neste item apontados apenas alguns que consideramos essenciais na compreensão destes complexos processos.

\subsubsection{Desenvolvimento e aprendizagem em pessoas com deficiência}

Baseados na posição teórica adotada, podemos inferir que ter alguma deficiência, quer seja ela física ou mental, traz algumas características e condições específicas para o desenvolvimento das pessoas. Porém, aquilo que elas poderão aprender e como se desenvolverão, não estão determinados a priori. Mas estão relacionados de forma interdependente com tudo aquilo que elas vivenciarão ao longo de suas vidas. Retomando as idéias de Piaget e Inhelder (1968/1999), o desenvolvimento é o resultado da maturação, experiência, interação social coordenados pelo processo de equilibração. Por isso, não podemos dizer que o desenvolvimento e a aprendizagem de pessoas com deficiência estão determinados pelas características que os déficits conferem ao sujeito. E, ao mesmo tempo, temos que considerá-las como um dos fatores, entre outros, que delimitam o seu desenvolvimento e a sua aprendizagem.

De acordo com a Classificação Internacional de Deficiências, Incapacidades e Desvantagens: um manual de classificação das consequiências das doenças - CIDID (1989, citado por AMIRALIAN et al 2000), deficiência refere-se a:

[...] perda ou anormalidade de estrutura ou função psicológica, fisiológica ou anatômica, temporária ou permanente. Incluem-se nessas a ocorrência de uma anomalia, defeito ou perda de um membro, órgão, tecido ou qualquer outra estrutura 
do corpo, inclusive das funções mentais. Representa a exteriorização de um estado patológico, refletindo um distúrbio orgânico, uma perturbação no órgão. (p.98).

A partir de 2001 a CIDID foi substituída pela CIF (Classificação Internacional de Funcionalidade). Nessa nova classificação, o termo funcionalidade vem substituir os termos usados no passado: deficiência, incapacidade e desvantagem com o objetivo de ampliar as experiências positivas e potencialidades das pessoas portadoras de deficiência. A CIF divide o sistema de classificação em cinco componentes: função corporal, estrutura do corpo, atividade social e participação social e ambiente. Os dois primeiros componentes relacionam-se com a deficiência ou com a doença. (BATTISTELLA; BRITO, 2002).

Apresentaremos a seguir algumas informações a respeito das possíveis características das deficiências dos alunos do nosso estudo. Estas se dão em função de suas condições genéticas (síndrome de Down) e neurológicas (paralisia cerebral). Consideramos que estas informações podem ser ilustrativas e auxiliar na compreensão do texto.

Síndrome de Down ${ }^{24}$ é o nome dado ao conjunto de sinais e sintomas determinados por uma alteração cromossômica. Normalmente temos 46 cromossomos (ou vinte e três pares) em cada célula (exceto nas células germinativas) do nosso corpo. Os cromossomos são estruturas que contém as características hereditárias de cada pessoa. Em decorrência de um acidente genético, em que a causa ainda não pôde ser determinada com precisão, ocorre a falha no processo de divisão celular no momento da concepção. Esta falha pode gerar 47 cromossomos em todas as células do feto, sendo que o cromossomo a mais será o do par 21. Neste caso, temos a trissomia do 21 ou trissomia simples, responsável por $95 \%$ dos casos. Em outros $3 \%$ a $4 \%$ dos casos, o número total de cromossomos nas células é de 46 , mas o cromossomo do par 21 extra fica ligado, sobreposto ou translocado para outro cromossomo, geralmente ao cromossomo 14, 21 ou 22. Neste caso, temos a trissomia por translocação. Um terceiro tipo de falha ainda pode ocorrer em torno de $1 \%$ dos casos. Quando o bebê nasce, encontram-se algumas células com 47 cromossomos e

${ }^{24}$ As informações relacionadas à síndrome de Down estão baseadas nas referências: Mauá (2002a), Pueschel (1993), Saad (2002) e Schwartzman (1999). A última autora realizou um detalhamento de aspectos históricos, etiológicos, clínicos, neurológicos, comportamentais e educacionais relacionados a essa síndrome. 
outras com 46 cromossomos. Este quadro corresponde ao que se chama de mosaicismo (PUESCHEL, 1993).

Algumas das características físicas freqüentemente presentes em pessoas com esta síndrome são: cabeça um pouco menor e levemente achatada; olhos amendoados, com pálpebras estreitas e levemente oblíquas, com prega de pele no canto interno e íris com manchas brancas; orelhas pequenas, com borda superior dobrada e canais do ouvido estreitos; boca pequena e muitas vezes se mantém aberta com a língua projetando-se para fora; pescoço com aparência larga e grossa; mãos curtas e largas e palmas apresentam uma única linha transversal; tônus muscular (tensão muscular) diminuído (hipotonia muscular). Com relação a alterações clínicas podemos ter: cardiopatias congênitas, presentes em 40\% dos casos; infecções respiratórias por uma predisposição imunológica e pela própria hipotonia do trato respiratório; aumento do hormônio da tireóide, podendo ocasionar obesidade; déficits visuais; déficits auditivos devido ao aumento de cera no conduto auditivo, de infecções de ouvido ou da malformação da cadeia ossicular; déficit mental.

Com relação ao desenvolvimento mental, Morato (1993), citando os estudos de Rydners (1987), Stratford (1985), Carr (1985) e Morss (1985), entende que a população com Trissomia 21 deve ser considerada virtualmente, "sempre com deficiência mental, ainda que em diferentes níveis" (p.34). Entretanto, este autor e Pueschel (1993) negam pelas investigações sobre o tema, que estas pessoas tenham em sua maioria um déficit mental profundo. Os últimos autores acreditam que esta visão está ligada a uma visão estereotipada do passado.

É importante ressaltar que nem sempre todas estas características estão presentes em todas as pessoas com esta síndrome. E, que outras características herdadas dos pais, bem como as influências do meio em que vivem, contribuem para o desenvolvimento físico, mental e social das pessoas com síndrome de Down. (MAUÁ, 2002a; PUESCHEL, 1993; SAAD; 2002; SCHWARTZMAN, 1999). 
Paralisia cerebral ${ }^{25}$ é o termo utilizado para definir um grupo heterogêneo de distúrbios, não progressivos, decorrentes de lesão no cérebro no período pré-natal, peri-natal e pós-natal. O prejuízo motor é a alteração mais freqüente, embora também possa haver prejuízos nos aspectos visuais, auditivos, psicológicos, mentais e de linguagem. A alteração motora é, direta ou indiretamente, responsável pela maior parte das alterações que a pessoa com paralisia cerebral terá ou não, uma vez que o componente motor está presente nas habilidades de andar, manipular, falar, escrever, entre outras. Crises convulsivas também podem estar presentes. (BASIL, 1995; SCHWARTZMAN, 1992; SOUZA, 1998).

De acordo com Basil (1995), as possíveis causas das lesões ocorridas no período pré-natal são: doenças infecciosas da mãe, como rubéola, sarampo, sífilis, herpes, hepatite epidêmica, meningite, toxoplasmose, intoxicações devido ao óxido de carbono, medicamentos, raio $\mathrm{X}$ e manobras abortivas mal controladas. Todas elas podem ocasionar malformações cerebrais; falta de oxigenação cerebral por insuficiência cardíaca da mãe, anemia, hipertensão, circulação sangüínea deficiente, incapacidade dos tecidos em captar o oxigênio; acúmulo de substâncias tóxicas por doenças metabólicas congênitas, como a galactosemia (defeito no metabolismo dos carboidratos) e a fenilcetonúria (defeito no metabolismo dos aminoácidos); excesso de bilirrubina (icterícia) por incompatibilidade sanguiínea entre crianças Rh positivas, nascidas de mães Rh negativas, previamente, sensibilizadas. Isto é, que já tiveram contato com sangue Rh-positivo, por exemplo, através de transfusão de sangue. Neste caso os anticorpos da mãe provocam a destruição dos glóbulos vermelhos da criança.

A obstrução do cordão umbilical, a anestesia administrada em quantidade excessiva ou em momento inoportuno, um parto muito demorado ou uma cesariana secundária podem ocasionar anóxia cerebral, isto é, falta de oxigenação das células cerebrais. Esta é a causa mais freqüente nas alterações peri-natais, além dos traumatismos ocorridos durante o parto (utilização inadequada do fórceps), mudanças bruscas de pressão, prematuridade ou hipermaturidade do feto.

\footnotetext{
25 As informações relacionadas à paralisia cerebral foram baseadas nos seguintes trabalhos: Basil (1995), Mauá (2002a), Sala (2003), Schwartzman (1992), Souza (1998), Yazlle (2002).
} 
As causas pós-natais ocorrem quando o sistema nervoso ainda se encontra em desenvolvimento, aproximadamente durante os três primeiros anos de vida. Elas podem ser decorrentes de infeções (como meningite ou encefalite), traumatismos na cabeça, acidentes anestésicos, distúrbios vasculares e intoxicações.

A paralisia cerebral pode ser classificada de acordo com o tipo e partes do corpo com alterações motoras.

Com relação ao tipo, temos: paralisia cerebral espástica - provoca o aumento do tônus muscular, hiperreflexia (reação exacerbada dos reflexos) e paresia (perda parcial da motricidade). É o tipo mais freqüente; paralisia cerebral atetóide flutuação do tônus muscular e movimentos involuntários; paralisia cerebral atáxica - provoca dificuldade na coordenação dos movimentos, deficiência do equilíbrio e percepção espacial e $\underline{\text { mista }}$ - quando dois tipos estão associados (por exemplo a espástica e a atetóide).

Quando consideradas as partes do corpo com alterações motoras, temos:

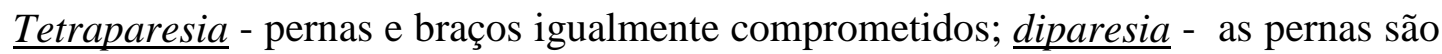
mais comprometidas do que os braços, ou os braços são mais comprometidos do que as pernas (menos comum); hemiparesia - um lado do corpo comprometido; monoparesia - apenas um membro é comprometido.

O nível de comprometimento no desenvolvimento dos aspectos visuais, auditivos, psicológicos, mentais e de linguagem depende da área e extensão da lesão, bem como das oportunidades de interações significativas com o meio ao longo da vida, principalmente nos primeiros anos de vida.

Fizemos esta breve caracterização de alguns aspectos envolvidos na síndrome de Down e na paralisia cerebral para que estas sejam consideradas como um dos fatores presentes no desenvolvimento e na aprendizagem dos alunos do nosso estudo. Mas, como vimos ao longo deste trabalho, são apenas alguns fatores. Além disso, concordamos com a afirmação de Ginzburg (1989, p.166):

As razões da 'incerteza' da medicina pareciam ser fundamentalmente duas. Em primeiro lugar, não bastava catalogar todas as doenças até compô-las num quadro ordenado: em cada indivíduo, a doença assumia características diferentes. Em segundo lugar, o conhecimento das doenças permanecia indireto, indiciário: o corpo vivo é, por definição, inatingível.

Para comentarmos alguns aspectos relevantes acerca das especificidades do desenvolvimento e da aprendizagem de pessoas com deficiência (quer seja 
deficiência mental e/ou motora, e/ou sensorial), temos como referência básica os pressupostos de Piaget (1966/1987) acerca da universalidade dos mecanismos da construção da inteligência. Estes pressupostos concebem que todas as pessoas seguem uma mesma sequiência evolutiva no desenvolvimento da inteligência variando apenas em ritmo, de acordo com as peculiaridades das características individuais e das trocas estabelecidas com o meio externo.

Estudos como o de Ide (1993), Mantoan $(1989,1991,2000)^{26}$ e textos como os de Coriat e Jerusalinsky (s/d), Ferreira (1993) discutem o desenvolvimento e a aprendizagem de pessoas com deficiência mental, apoiados no estudo realizado por Inhelder (1943/1971) sobre o desenvolvimento do raciocínio nestas pessoas.

Inhelder (1943/1971) comparou a estrutura e o processo de construção do raciocínio operatório entre crianças normais e 159 crianças com debilidade mental ${ }^{27}$. A principal meta em sua pesquisa foi investigar se a teoria do desenvolvimento de Piaget e o seu método de investigação poderiam servir de modelo e instrumento de análise para o diagnóstico do raciocínio em débeis mentais. Seus estudos confirmam positivamente esta hipótese e aponta algumas constatações que são referências para o estudo do processo de desenvolvimento em pessoas com deficiência mental.

A autora observou, com relação ao desenvolvimento de crianças com deficiência, que elas seguem a mesma sucessão nos estádios de desenvolvimento (sensório-motor, pré-operatório, operatório concreto), porém, numa velocidade mais lenta do que as crianças normais. Há uma diminuição gradual no ritmo do desenvolvimento que repercute em um estado estacionário do nível evolutivo que a criança atingiu, ocasionando o desenvolvimento de uma estrutura cognitiva inacabada. Isto é, chega a um estado em que as estruturas cognitivas não são passíveis de se transformarem em estruturas mais evoluídas, como as requeridas para o pensamento formal. Parece haver um "falso equilíbrio" nas operações mentais. Isto é, parece haver uma dificuldade no sistema adaptativo, oferecendo um equilíbrio aparente pela falta de mobilidade deste mesmo sistema. Esta foi a tendência que Inhelder denominou de viscosidade do raciocínio.

\footnotetext{
${ }^{26}$ Esta autora realizou nos dois últimos trabalhos citados um levantamento de estudos comparativos entre o desenvolvimento intelectual de pessoas normais e com deficiência. Estes estudos tiveram inspiração piagetiana e confirmaram os achados de Inhelder (1943/1971) que apresentaremos a seguir.

${ }^{27}$ Nomenclatura utilizada por Inhelder.
} 
Tratando dos aspectos estruturais e funcionais da vida intelectual de pessoas com deficiência, Mantoan (2000, p.56) apoiada nos trabalhos de Piaget e $\operatorname{Inhelder}^{28}$ e na constatação empírica de suas investigações com pessoas com deficiência mental, sinaliza três aspectos particulares:

- os deficientes mentais configuram uma condição intelectual análoga a uma construção inacabada [grifos da autora], mas até o nível em que conseguem evoluir intelectualmente, essa evolução se apresenta como sendo similar à das pessoas normais mais novas. Portanto, não existe uma diferenças estrutural entre o desenvolvimento cognitivo de indivíduos normais e deficientes;

- embora possuam esquemas de assimilação equivalente aos normais mais jovens, os deficientes mentais mostram-se inferiores às pessoas normais, em face da resolução de situações-problema, ou seja, na colocação em prática de seus instrumentos cognitivos;

- apesar de se definir por paradas definitivas e uma lentidão significativa no progresso intelectual, a inteligência dos deficientes mentais testemunha uma certa plasticidade ao reagir satisfatoriamente à solicitação adequada do meio.

Como dito anteriormente, a construção mental inacabada refere-se à dificuldade de pessoas com deficiência mental ascenderem às estruturas mais evoluídas do desenvolvimento cognitivo. Porém, este limite não é dado previamente a nenhum sujeito. Em outras palavras, a construção mental inacabada é uma condição freqüente nas pessoas com deficiência mental, mas não é um limitador prévio.

Em uma pesquisa anterior realizada com 52 alunos com deficiência mental, Mantoan (1989) constatou que os alunos apresentaram acesso a períodos de desenvolvimento cognitivo progressivamente mais evoluídos e condutas adaptativas mais complexas e objetivas frentes aos desafios do meio quando participaram de um programa educacional fundamentado em princípios construtivistas piagetianos. Ide (1993) também a partir do mesmo referencial teórico descreveu progressos no desenvolvimento cognitivo de alunos com deficiência mental, através do relato de suas professoras. Os dois estudos foram desenvolvidos em escolas especiais.

Ramalho, Pedromônico e Perissinoto (2000) avaliaram o desempenho motor, a coordenação e a linguagem de crianças com síndrome de Down (entre dois e cinco anos), atendidas na Associação de Pais e Amigos dos Excepcionais - APAE/SP. As autoras verificaram a mesma tendência hierárquica de aquisição nos desempenhos

\footnotetext{
${ }^{28}$ PIAGET, J. L'équilibration des structures cognitives - problème central du Développment. Paris: PUF, 1975 e INHELDER, B. Le Diagnostic du raionnement chez les débiles menatux. 3 ed. Suisse: Delachaux et Niestlé, 1963.
} 
observados do que as 21 crianças normais com as quais os seus desenvolvimentos foram comparados.

Saad (2002) demonstrou em sua investigação as potencialidades do desenvolvimento de 10 jovens com síndrome de Down, expressos nos seus relevantes desempenhos na produção escrita, leitura, oralidade, massagem terapêutica, computação, artes plásticas, natação e trabalho.

Morato (1993) verificou um efeito positivo de aquisição de conceitos espaciais em crianças com trissomia 21 em diferentes ambientes de aprendizagem.

Sem desconsiderar as especificidades encontradas nos estudos de Inhelder e nos seus próprios acerca do desenvolvimento cognitivo de crianças com deficiência mental, Ide (1993) e Mantoan (1989, 1991, 2000) reafirmam a importância da solicitação do meio para o desenvolvimento das estruturas mentais e melhores condições de funcionamento intelectual.

O sujeito necessita de experiências que o coloquem em situações-problemas para produzir perturbações que desencadeiem o funcionamento de seus esquemas para o conseqüente encadeamento do processo do desenvolvimento cognitivo. É importante ressaltar, que toda vez que falamos de experiências, consideramos que estas necessariamente têm que ser significativas para os sujeitos. Isto é, têm que ser experiências que provoquem no sujeito o desejo de realizá-las. Macedo (1999) comentando sobre aprendizagem significativa, refere que esta é fundamental para a busca de conhecimento. Segundo o autor, Piaget considera aprendizagem significativa como método ativo. Sendo que se esta "não for significativa, sua aquisição estará, cedo ou tarde, comprometida.” (MACEDO, 1999, p.18).

As considerações acima são válidas não só para pessoas com deficiência mental, mas também para pessoas com deficiência motora. Como mostra a teoria psicogenética de Piaget, no período sensório-motor, a exploração ativa do sujeito sobre o ambiente é fundamental para aquisição de esquemas, organização das estruturas mentais, assimilação, acomodação e conseqüente equilibração. Podemos certamente inferir que o comprometimento das funções motoras interfere negativamente no processo evolutivo, sobretudo por provocarem trocas deficitárias entre o sujeito e o meio. 
Coriat e Jerusalinsky (s/d) discutem as influências da hipotonia presente nas crianças com deficiência mental. Para estes autores, a hipotonia ocasiona uma diminuição da atividade motora global e espontânea, diminuindo as atividades sensório-motoras e reflexas. Estas são responsáveis pelo início do desenvolvimento dos esquemas de ação do bebê que seguirão as próximas aquisições referentes aos períodos do desenvolvimento proposto por Piaget.

Os aspectos sensoriais e motores são fundamentais para que o sujeito interaja no seu meio ambiente. Isto é, o bebê necessita ouvir, sentir, movimentar-se para conhecer o mundo e ser percebido por este. A sensação e ação segundo a teoria psicogenética de Piaget são fundamentais para o desenvolvimento cognitivo de todas as pessoas. É através das sensações e da ação que descobrimos o nosso próprio corpo, desenvolvemos nossa imagem corporal, estabelecemos nossas relações com as pessoas, com os espaços, com o tempo e com as atividades que fazem parte do nosso cotidiano.

Como vimos anteriormente, o principal prejuízo no desenvolvimento de crianças com paralisia cerebral está relacionado aos aspectos de sua motricidade, podendo também, ter alterações de ordem sensorial e mental. Assim sendo, tal como para as crianças com hipotonia, as crianças com paralisia cerebral (em que a hipotonia pode ser uma característica presente) têm um prejuízo nas suas trocas com o meio, principalmente devido à limitação no movimento ou a padrões de movimentação alterados e inadequados, como a presença constante de atividade reflexa, movimentação involuntária e uma hipertonia muscular.

Os trabalhos de Allegretti, Mancini e Schwartzman (2002), Basil (1995), Braccialli, Monteiro e Ravazzi (1998), Braga (1983), Carvalho, L.M.G. (1998), Limongi (1992), Lorenzini (1999), Heymer e Ganem (1993), Yazlle (2001), referem as dificuldades que as pessoas com paralisia cerebral podem ter no seu desenvolvimento global frente aos padrões anormais do desenvolvimento motor e sensorial como citado acima.

Apesar das dificuldades encontradas em pessoas com deficiência motora e/ou sensorial para estabelecerem uma troca efetiva com o meio que contribua para o seu desenvolvimento sensório-motor e conseqüente e indissociavelmente seu desenvolvimento cognitivo, temos várias possibilidades de minimizar os possíveis 
prejuízos para o seu desenvolvimento cognitivo global. Uma criança com síndrome de Down, por exemplo, apresenta como característica básica a hipotonia (redução do tônus munscular) generalizada. Se proporcionarmos situações que despertem o seu interesse e desejo e, por vezes, a auxiliarmos a explorar ativamente o meio, estaremos contribuindo para o desenvolvimento de seu esquema motor. Mesmo que este seja deficitário ou inexistente - como é o caso de algumas crianças com paralisia cerebral - também não podemos esquecer da nossa dimensão sensorial.

Os nossos órgãos do sentido são fundamentais na recepção das informações do meio. Recorrendo a conhecimentos da fisiologia humana (GUYTON, 1984) sabemos que a maior parte das atividades do sistema nervoso tem início com a experiência sensorial derivada dos receptores sensoriais (visual, auditivo, táteis e outros). Essa experiência sensorial pode provocar uma reação imediata ou pode ser armazenada como memória no encéfalo por minutos, semanas ou anos, capacitando-se a auxiliar numa oportunidade futura. Isto é, cada vez que um impulso sensorial particular passa através de uma seqüência de sinapses (processo de comunicação entre as células do sistema nervoso - neurônios), estas se tornam mais capazes de transmitir o mesmo impulso da próxima vez. Quanto mais informações sensoriais recebermos e quanto mais estas formarem redes de conexões até o sistema nervoso central, mais possibilidades teremos de gerar reações motoras e/ou desencadear processos cognitivos.

Segundo Lima (1997), vários neurocientistas apontam que cada cérebro é diferente do outro no desenho do estabelecimento das conexões sinápticas, sendo este análogo à impressão digital, que é única para cada pessoa. Para a autora, "a configuração de redes neuronais se constituirá em função do conjunto de experiências do indivíduo assumindo, portanto, uma configuração individual.” (p. 21). Considera que o desenvolvimento é "simultaneamente orgânico e social." (p.24). Para Annunciato (2000), a complexa organização das conexões neurais deve ser o resultado de um processo progressivo e seqüencial da interação entre o sistema nervoso e o seu micro-ambiente.

O prejuízo na função motora de pessoas com paralisia cerebral pode alterar a função cognitiva. Esta alteração, muitas vezes, não é primária ao quadro, mas sim secundária à não exploração do meio. Além disso, o potencial cognitivo destas 
crianças pode muitas vezes ser desvalorizado porque ao não responderem como a maioria das pessoas às solicitações do meio, principalmente expressas pelas respostas verbais, elas são consideradas como incapazes de desenvolver um raciocínio lógico.

Quando as pessoas com alterações motoras, sejam elas leves ou severas, são estimuladas por vias sensoriais para a exploração ativa do ambiente com as partes do corpo disponíveis, elas podem ter um desenvolvimento cognitivo adequado às suas necessidades de interação e interpretação do meio. Isto é, estas crianças necessitam de experiências que minimizem suas deficiências motoras e facilitem suas respostas às solicitações do meio (LORENZINI, 1999).

A teoria de Integração Sensorial proposta por A. Jean Ayres, terapeuta ocupacional americana, citadas por Babey e Michael (1995) mostra-nos a importância de oferecermos experiências sensoriais para a organização das informações em prol de um melhor desenvolvimento intelectual e conseqüente adaptação ao meio.

A plasticidade do sistema nervoso central propicia a toda pessoa uma multiplicidade de caminhos de desenvolvimento (LIMA, 1997). A plasticidade cerebral refere-se à capacidade de as células neuroniais moldarem-se a novas funções quando as vias nervosas são estimuladas e utilizadas, quer sensorialmente, quer motoramente. Silva, R.K. (2000) fazendo uma revisão de literatura sobre a neuroplasticidade no desenvolvimento de crianças com paralisia cerebral, descreve dois mecanismos básicos segundo os quais a plasticidade neuronal pode ocorrer. $\mathrm{O}$ primeiro refere-se a formação de brotos sinápticos nas células que não foram lesadas para reorganizar a função alterada. $O$ segundo mecanismo diz respeito a ativação de vias que ainda não estavam incorporadas funcionalmente, quer por uma ação homeostática (quando a atividade cerebral diminui), quer pela ativação de vias que não estavam envolvidas em nenhuma função específica. Em ambos os casos, a reorganização neuronal se dá pela estimulação das vias sensoriais e motoras. Exemplificando: na paralisia cerebral temos, em algumas situações, a morte dos neurônios, células que não se regeneram. Porém, graças a plasticidade é possível que novas células sejam ativadas para desempenhar a função que caberia àquelas que morreram. A plasticidade neuronal mostra que o cérebro é capaz de se organizar e 
reorganizar em contato com situações provocativas e a partir das solicitações do meio externo.

Lorenzini (1999) constatou que o brincar, a valorização do ambiente natural, a interação mãe e filho podem contribuir efetivamente para o desenvolvimento sensório-motor da criança com paralisia cerebral.

Limongi (1992) verificou em 3 crianças com paralisia cerebral espástica entre 7 e 10 anos, com níveis de fala que permitia a comunicação oral que ao processo cognitivo e à construção da linguagem oral seguem a gênese proposta por Piaget na qual a construção do conhecimento está na lógica das ações.

Braccialli, Monteiro e Ravazzi (1998) verificaram que a dança e a música contribuíram à evolução da capacidade rítmica, do desenvolvimento motor e da independência nas atividades de vida diária de 4 pessoas com paralisia cerebral grave ou moderada de 10 a 15 anos de idade.

O estudo de Andretto (2001) observou o benefício da frequiência na primeira série do ensino fundamental de um aluno com paralisia cerebral de 8 anos de idade. Segundo este trabalho o aluno conseguiu cumprir praticamente toda a programação escolar que seus pares com o auxílio de um computador e uma ponteira de cabeça. Desenvolveu sua capacidade de escrita, ampliou sua capacidade comunicativa, sua autonomia nas tarefas escolares e sua responsabilidade, favorecendo sua independência.

Entretanto, Pfeifer (1997) aponta que existem poucos estudos sobre o desenvolvimento cognitivo de crianças com paralisia cerebral. A maioria dos trabalhos enfoca o desenvolvimento motor.

O que apresentamos acerca do desenvolvimento e da aprendizagem de pessoas com deficiência são apenas alguns elementos que sustentam os enunciados que a Teoria Psicogenética de Piaget e de outras áreas do conhecimento nos proporcionaram. 


\subsection{Cotidiano e cotidiano escolar}

Para nós a afirmativa: “todos podem aprender”! (MACEDO, 2002a, p.131) é uma premissa que norteia o nosso estudo, tal como: "A vida cotidiana é a vida de todo homem. Todos a vivem, sem nenhuma exceção"! (HELLER, 1970/s.d., p. 17).

Agnes Heller foi uma importante teórica que estudou o conceito de cotidiano na dimensão histórica das relações de produção e reprodução existentes na sociedade capitalista apoiada na teoria marxista. Foge da relevância deste trabalho atermo-nos a vertente analítica do conceito de cotidiano proposto por esta autora. Entretanto, utilizamos algumas de suas idéias teóricas para formular algumas extrapolações para compreender a importância da vivência de um cotidiano escolar para o desenvolvimento e a aprendizagem de todas as crianças.

Para Heller (1987) atividades cotidianas são aquelas que caracterizam a reprodução do homem singular ${ }^{29}$. Se entendermos reproduzir como "dar origem a" (HOUAISS, 2001), podemos dizer que as atividades cotidianas são aquelas que dão origem ao homem singular. Se entendermos como "perpetuar', temos a idéia de que são as atividades necessárias para que o homem se mantenha "por tempo indeterminado, por longo período" (HOUAISS, 2001). Segundo a autora, as atividades cotidianas não são, necessariamente, realizadas todos os dias. Podemos ter como exemplo a atividade de ir ao supermercado. Embora não necessitamos ir ao supermercado todo dia, esta atividade é cotidiana porque ela é necessária para que tenhamos alimentos e outros produtos para sustentação da nossa vida.

Ao refletirmos sobre as características que Heller (1970/s.d.) atribui à vida cotidiana, podemos estabelecer algumas relações entre estas características e as condições da vida cotidiana das pessoas com deficiência. A seguir, apresentamos algumas delas.

Toda pessoa, independentemente de sua condição intelectual e física, pode viver a cotidianidade e não somente ela. Isto é, pode viver outras esferas da vida consideradas por Heller (1970/s.d.) como sendo da dimensão não-cotidiana, como a

\footnotetext{
${ }^{29}$ Agnes Heller (1987) faz a distinção entre atividades cotidianas e atividades não-cotidianas. Estas últimas são aquelas que estão voltadas para a reprodução da sociedade. Cita como exemplo de atividades desta natureza a arte, a ciência a política.
} 
esfera política, das artes, das ciências, etc. Consideramos, na condição genérica proposta pela autora, a pessoa com deficiência como todo homem ${ }^{30}$.

A pessoa com deficiência pode e deve participar da vida cotidiana com todos os aspectos de sua individualidade, de sua personalidade. É através da vida cotidiana que os homens têm a possibilidade de colocar em “'funcionamento' todos os seus sentidos, todas as suas capacidades intelectuais, suas habilidades manipulativas, seus sentimentos, paixões, idéias, ideologias." (HELLER, 1970/s.d., p. 17). A vida cotidiana é a vida do homem inteiro.

Percebemos que à pessoa com deficiência é restringida a circulação nas partes orgânicas da vida cotidiana. Isto é, muitas vezes ela é, em princípio, tida como incapaz de usufruir do lazer ("ela não sabe brincar"), freqüentar os espaços regulares da sociedade, como a escola ("ela não tem condições de aprender e acompanhar os outros alunos da escola regular"), ter acesso ao trabalho ("ela não tem responsabilidade para isso, ela não sabe fazer nada ${ }^{31 ") . ~ E m ~ c o n t r a p a r t i d a, ~}$ considerando que a vida cotidiana é heterogênea, deveríamos oferecer oportunidades de vivência, experimentação e expressão em todas as partes potencialmente possíveis para elas.

A vida é centrada no acontecer histórico. Portanto, acreditamos que é possível mudar a história da pessoa com deficiência - de um ser improdutivo, dependente e que por isso, deve ser excluído e segregado, para um ser atuante e fruidor, valorizado e aceito a partir do que é e do que pode vir a ser - se ele puder viver na integridade o cotidiano.

Na maior parte dos casos, a individualidade da pessoa com deficiência é restrita, não lhe é permitido o desenvolvimento da consciência e escolha relativamente livre. As atividades de cuidado próprio que poderiam ser realizadas por ela, se tivesse oportunidade de desenvolvê-las, são realizadas muitas vezes por outros. Assim sendo, o que a caracteriza a vida do indivíduo com deficiência são muito mais seus elementos humano-genéricos (o que é comum à "classe dos deficientes", aos papéis sociais dos deficientes, às suas limitações) do que a sua singularidade e as suas possibilidades. Se oferecermos oportunidades para a pessoa com deficiência

\footnotetext{
${ }^{30}$ As palavras em negrito, nesta parte do texto, referem-se a algumas características que Heller considera compor a estrutura da vida cotidiana.

${ }^{31}$ Falas ouvidas no decorrer da prática profissional da pesquisadora.
} 
desenvolver sua singularidade, ela poderá ter sua expressão no humano-genérico não estereotipada e limitada.

As escolhas no cotidiano da pessoa com deficiência são feitas, muitas vezes, por outrem. Assim, suas alternativas no cotidiano são restritas. A espontaneidade da pessoa com deficiência, muitas vezes, é julgada como fruto de "atos impensados, atos irracionais, sem motivos ou exagerados". Porém, estes podem ser simplesmente a expressão de seus desejos e compreensão naquele momento da realidade, que às vezes precisam ser contextualizados.

Nos cabe incentivar e investir nas possibilidades de desenvolvimento da pessoa com deficiência, porque o que seremos amanhã está no campo das possibilidades, e não determinado a priori. Por isso, a vida destas pessoas, como a de todos, é de possibilidades.

É mais freqüente ouvirmos com relação as pessoas com deficiência: "tenho fé que ele vai se desenvolver, aprender (embora nem isso ouvimos com freqüência), do que: "tenho confiança de que ele vai se desenvolver, aprender". Isto é, pelas determinações históricas, pelo senso comum, pelo preconceito, acabamos por não acreditar de fato nas possibilidades que elas têm.

Acreditamos que a pessoa com deficiência ao estar inserida nos cotidianos "regulares" da sociedade, terá a oportunidade da mimese, de imitar os hábitos que se manifestam nestes e consequentemente pô-los em movimento e configurar novas atitudes. Ela também pode dar o tom da cooperação e da solidariedade. Isto é, ela explicita para todos, a nossa condição de incompletude e interdependência, o que nos convida a cooperar e ser solidário nas nossas relações sociais.

Uma educação inclusiva se presta a romper com a tendência de alienação da vida cotidiana, pois impõe desafios, quebra de preconceitos e paradigmas cristalizados. Conduzir a vida para que ela não seja alienada, implica a necessidade de incluir a reflexão como uma das partes orgânicas do cotidiano.

Através dos elementos teóricos que Heller (1970) propõe, entendemos que a pessoa com deficiência pode viver sua cotidianidade, desenvolvendo sua singularidade num contexto de interdependência. Devemos oportunizar a manipulação das coisas que serão assimiladas, bem como as relações sociais. 
Para nós, estas relações justificam a importância da inclusão social e escolar das pessoas com deficiência porque, só podemos nos desenvolver e aprender quando estamos incluídos em contexto social que ofereça oportunidades da vivência das atividades cotidianas na plenitude possível para cada um.

O que consideramos interessante da visão sobre a vida cotidiana proposta por Heller e que incorporamos na nossa compreensão de cotidiano, é que as atividades cotidianas são aquelas que possibilitam que o homem se constitua como sujeito único, sendo ou não realizadas todos os dias, podendo ou não envolver uma rotina (caminho habitual). Além disso, para nós o cotidiano é aquilo que confere ao sujeito a possibilidade de ser validado como sujeito social, pois, o possibilita exercer atividades que o permite se desenvolver, aprender e ter uma participação no contexto em que vive. Esta é a compreensão de cotidiano que permeou esta pesquisa.

Consideramos interessante recuperar a aproximação da autora com a dimensão do cotidiano, para detalharmos a relevância desta pesquisa apoiar-se na importância das relações no cotidiano escolar para o desenvolvimento e a aprendizagem de crianças com deficiência ${ }^{32}$.

Como apresentei no início deste trabalho, minha formação e prática profissional estão intimamente ligadas com a esfera da vida cotidiana. $\mathrm{Na}$ minha prática profissional como terapeuta ocupacional, lido com situações em que pessoas que apresentam déficits nas áreas motoras, sensoriais, mentais, psíquicas e sociais têm dificuldades em realizar atividades cotidianas, o que pode prejudicar sua participação social $^{33}$. Portanto, como nos explicita Benetton (1994, p.7) “a exclusão social é a problemática de partida para a terapia ocupacional" e a inclusão social o objetivo último dos seus procedimentos de intervenção.

\footnotetext{
${ }^{32}$ Utilizo para reflexão nesta aproximação os trabalhos de: Amaro e Couto (1999), Bennetton (1994, 1996, 1999), Brunello (2001), Carlo e Bartalotti (2001), Carvalho, M.A. (1997), Fenili e Sant'anna (2001), Paganizzi (2002), Sant'anna (2002), Takori (1999, 2003).

${ }^{33}$ A dificuldade na participação social não se dá exclusivamente em decorrência dos déficits que as pessoas apresentam, mas, também, da dificuldade do meio em se adaptar às necessidades destas pessoas. Lembramos que o conceito de Inclusão Social segundo Sassaki (1997) diz respeito ao: "processo pelo qual a sociedade se adapta para poder incluir, em seus sistemas sociais gerais, pessoas com necessidades especiais e, simultaneamente, estas se preparam para assumir seus papéis na sociedade. A inclusão social constitui, então, um processo bilateral no qual as pessoas, ainda excluídas, e a sociedade buscam, em parceria, equacionar problemas, decidir sobre soluções e efetivar a equiparação de oportunidades para todos". (p.41).
} 
Falar de problemas na inclusão social implica ingressar numa dimensão muito ampla de interpretação e atuação. Isto é, uma pessoa pode ser excluída porque não tem trabalho e, sem este, não tem recursos financeiros para seu sustento e vida com dignidade. Pode ser excluída do mundo de significados e interpretações que nos rodeiam por ter alterações mentais. Pode ser impedida de circular pelos espaços da comunidade como ruas, supermercados, bancos, parques, entre outros, por ter alterações no seu desenvolvimento motor. Pode ter alterações mentais, motoras ou psíquicas que a incapacitem de realizar suas atividades de cuidado próprio, como ir ao banheiro, escovar os dentes, tomar banho, despir-se, vestir-se, alimentar-se, locomover-se, trabalhar entre outras ${ }^{34}$. Enfim, a problemática de inclusão social sob o olhar da terapia ocupacional debruça-se sobre todas as alterações que provocam comprometimentos na vivência das atividades cotidianas, quer do ponto de vista do sujeito, quer do ponto de vista do contexto em que vive. Assim, a vivência das atividades cotidianas passa a ser o meio para o desenvolvimento de habilidades da melhor forma possível para cada sujeito e que, ao mesmo tempo, é o nosso foco de observação e análise constantes.

Desde o início de minha formação profissional fui conduzida, principalmente nas disciplinas de graduação e de pós-graduação, ${ }^{35}$ a vivenciar o processo de realização das atividades para compreender a psicodinâmica envolvida nestes processos, analisando os aspectos perceptivos, cognitivos, motores, mentais, psíquicos, culturais e sociais da nossa vida cotidiana. Estas atividades são aparentemente simples para quem tem os recursos satisfatórios para sua execução e por isso as automatizam ou as realizam sem muito dispêndio de força, energia e concentração. Porém, a

\footnotetext{
34 A deficiência pode ou não gerar uma incapacidade. Esta pode ou não se traduzir numa desvantagem. Segundo a OMS: "Incapacidade: restrição, resultante de uma deficiência, da habilidade para desempenhar uma atividade considerada normal para o ser humano. Surge como conseqüência direta ou é resposta do indivíduo a uma deficiência psicológica, física, sensorial ou outra. Representa a objetivação da deficiência e reflete os distúrbios da própria pessoa, nas atividades e comportamentos essenciais à vida diária. Desvantagem: prejuízo para o indivíduo, resultante de uma deficiência ou uma incapacidade, que limita ou impede o desempenho de papéis de acordo com a idade, sexo, fatores sociais e culturais. Caracteriza-se por uma discordância entre a capacidade individual de realização e as expectativas do indivíduo ou do seu grupo social. Representa a socialização da deficiência e relaciona-se às dificuldade nas habilidades de sobrevivência". (AMIRALIAN et al, 2000, p.98).

${ }^{35}$ Destaco aqui a disciplina de Atividades e Recursos Terapêuticos do curso de Graduação em Terapia Ocupacional da Pontifícia Universidade Católica de Campinas e a disciplina Laboratório de Atividades do curso de Especialização em Saúde Mental em Terapia Ocupacional realizado no Centro de Estudos em Terapia Ocupacional - CETO, São Paulo / S.P. Durante o meu percurso no programa de pós-graduação também tive a oportunidade de compartilhar com o meu orientador estas questões.
} 
complexidade delas são explicitadas nas pessoas cujos recursos são insuficientes ou precários para a sua realização.

Para exemplificar esta complexidade, vamos pensar que funções nos são exigidas no âmbito cognitivo, motor, psíquico / emocional e cultural / social para realizar a "simples" atividade de escovar os dentes.

Apontando apenas algumas destas funções ${ }^{36}$, temos:

- funções cognitivas: conhecer as partes de seu corpo até saber onde estão e para que servem seus dentes; identificar e conhecer a função de uma escova de dente e um creme dental; saber localizar entre os diversos espaços físicos e lugares aonde estes são guardados; conhecer os movimentos e ações que são necessários para abrir o creme dental, apertá-lo, ter noção da força e quantidade de creme necessário etc.

- funções motoras: movimentação dos braços e mãos para segurar a escova e o creme dental, movimentos de flexão e extensão de braço, antebraço e mão, força muscular para segurar a escova e apertar o creme dental; coordenação dos movimentos de flexionar antebraço, subir e descer, com dedos fletidos, a mão em movimentos seqüenciais, para que a escova de dente esfregue todos os dentes etc.

- funções psíquicas/emocionais: quando uma pessoa está deprimida, talvez ela não veja a importância de escovar seus dentes ou também, quando uma pessoa está cindida com a realidade ela pode perder o significado da importância desta atividade.

- funções culturais/sociais: dependendo da cultura de cada povo, nação, região, família, escovar os dentes pode ou não ser um hábito cultivado, e com diferenças na quantidade de vezes que cada um considera necessário para tal; dependendo da condição sócio-econômica de cada pessoa ela pode ter condições de escovar os dentes com creme dental ou não.

Como se pode ver, escovar os dentes não é tão "simples" assim. É claro que nem todas as pessoas possuem todas essas funções para a realização desta atividade. No entanto, podemos - esta é também uma função dos procedimentos técnicos da terapia

\footnotetext{
${ }^{36}$ Estas funções são apresentadas de forma simplificada e compartimentalizada apenas para evidenciar a multiplicidade de elementos envolvidos na execução desta atividade. Porém, estas funções são articuladas entre si.
} 
ocupacional - criar dispositivos, recursos e adaptações para que esta atividade seja realizada por pessoas que tenham alguma dificuldade em uma ou várias das funções apontadas.

Ao observar e analisar várias das atividades realizadas no cotidiano escolar, podemos verificar que várias delas não são simples! Principalmente se as pensarmos em uma dimensão inclusiva, considerando que elas devem beneficiar o desenvolvimento e aprendizagem de todos os alunos.

Quando, em 1998, começamos a sistematizar ações de apoio a professores de escolas regulares que recebiam alunos com deficiência, uma série de questões trazidas por eles evidenciavam preocupações e necessidades ligadas com problemáticas envolvidas direta ou indiretamente com o cotidiano escolar. Eis aqui algumas delas ${ }^{37}$ :

Como devo agir com a pessoa com deficiência? Devo tratá-la diferente? O que devo ensiná-la? O que ela tem condições de aprender? Existem técnicas específicas para o ensino destes alunos? Qual é o problema ou deficiência do meu aluno? Ele não vai se sentir constrangido no ensino regular ao perceber que é diferente do outro, que não aprende do mesmo jeito e nem se comporta como os outros? Não sendo especializada para trabalhar com estas pessoas elou não me sentindo preparada, posso ser a mais indicada para ser a professora dele? Por que alguns alunos não aprendem ou têm dificuldades em ler / escrever / realizar operações matemáticas / realizar uma seqüência lógica / ou qualquer outro processo ligado a abstração elou memória? Como identificar qual é o motivo pelo qual ele não aprende? Quais são esses possíveis motivos? Deficiências, dificuldades / distúrbios / transtornos de aprendizagem ou outros transtornos do desenvolvimento mental elou psíquicos, interesse, proposta de ensino? Até quando um aluno com deficiência ou dificuldade no aprendizado deve ficar na escola? A escola é o melhor local para que eles possam adquirir independência, autonomia, conhecimentos para resolução de problemas da vida cotidiana? Pensando que a suplência é um sistema de ensino em

\footnotetext{
${ }^{37}$ Algumas destas questões estão presentes no texto: “Avaliação das ações da equipe de apoio no $1^{\circ}$ semestre de 1999" (MAUÁ,1999b). Outras no trabalho publicado: "Da lógica da exclusão à lógica da inclusão: uma estratégia de apoio à inclusão escolar" (AMARO e MACEDO, www.educacaoonli.pro.br). Outras são retiradas da minha lembrança desta experiência de trabalho.
} 
que os alunos têm "pressa" em aprender, principalmente pela necessidade de inserção no mercado de trabalho, ele seria o melhor sistema para pessoas com deficiência ou grandes dificuldades no aprendizado estarem? Quais os parâmetros para avaliação deste aluno? O que fazer quando o aluno tem crises convulsivas ou outra intercorrência orgânica na escola? Qual é a responsabilidade da escola/professor caso venha acontecer estas situações acarretando problemas sérios ou até o falecimento do aluno? O que fazer com crianças agressivas? Devo impor limites, punir? Como lidar com os alunos apáticos? Qual deve ser minha atitude frente aos comportamentos destes alunos e de sua família? O que eu estou fazendo está ajudando ou não o aluno? O que fazer com o aluno que tira a gente do sério, que nos desafia? Como me comunicar e que atividades devo dar para os alunos que: não falam, não ouvem, não se interessam pelas atividades e pelo contato com outros, não se concentram, não estruturam brincadeiras, evitam olhar para os outros, gostam de brincar sozinho, repetem sempre os mesmos desenhos, não acompanham os outros alunos, não enxergam, não mexem as mãos, são muito agitados, circulam o tempo todo pela sala, são "hiperativos", são "terríveis", fazem coisas que tem perigo para eles e machuca os outros? Qual é o papel da escola para estes alunos? Como posso ter um aluno com dificuldade de locomoção, se minha escola está cheia de escadas? Como é possível dar aula para estes alunos sem excluir os outros, já que temos um grande número de alunos na sala de aula? Como trabalhar com os alunos para que eles aceitem os colegas deficientes? Será que estes alunos devem passar de ano, já que eles não acompanharam o conteúdo? Será que na outra escola eles vão dar a atenção que eles precisam? Estes alunos não precisam tomar remédio? Como e quando eu devo encaminhar os alunos para Educação Especial?

Ao me deparar com elas no início deste trabalho de apoio, a primeira coisa que me vinha a cabeça é que parecia um "labirinto sem saída", já que as demandas colocadas eram inúmeras, de natureza diversas e muito complexas!

Fui percebendo que fundamentos que eu aprendi a valorizar e tornaram-se subsídios na minha prática profissional poderiam contribuir para apontar alguns caminhos possíveis para lidar com estas problemáticas e construir um contexto mais 
favorável para a educação desses alunos no cotidiano escolar que objetiva ser inclusivo.

O conceito de diagnóstico situacional desenvolvido por Bennetton (1994) para compreender a problemática do sujeito que necessita de alguma intervenção para a sua inclusão nas atividades cotidianas sobre o olhar da terapia ocupacional, foi essencial nestes caminhos. Ele contribuiu para compor junto com os profissionais que traziam as questões citadas acima, uma melhor compreensão das necessidades dos alunos e os caminhos possíveis de serem trilhados para desenvolver suas habilidades e possibilidades de aprendizagem. O diagnóstico situacional mostra-nos a importância de considerarmos as várias dimensões envolvidas nas "queixas". Para compreender melhor por que o aluno não se interessa em realizar as atividades propostas, por exemplo, temos que analisar uma série de questões, tais como: Que atividades ele não se interessa em realizar? Será que dentre tudo o que acontece no cotidiano da escola (nas atividades de desenho, pintura, brincadeiras, jogos, escrita, chamada, organização do espaço, de alimentação, de higiene, no parque, entre outros) não tem nada que ele faz e / ou gosta de fazer? Como são propostas estas atividades para serem realizadas? Será que o aluno compreende o que está sendo pedido? Será que o aluno tem recursos e habilidades (cognitivas, motoras, culturais, materiais, entre outras) necessárias para realizar estas atividades propostas? Será que elas são significativas para o aluno? O que a mãe, o pai, a tia diz que ele faz e gosta de fazer em casa? Algum outro profissional da escola já observou ele realizando alguma atividade? Qual? Como ele realizou? Quem estava com ele? Tem alguma pessoa (professor, aluno, funcionário, ou outros) com quem o aluno tem uma referência afetiva positiva que ele atende quando uma determinada atividade lhe é proposta?

Essas são apenas algumas questões que mostram a importância de compreendermos melhor todo o contexto que envolve a "queixa" para pensarmos formas de lidar com a situação.

$\mathrm{Na}$ Terapia Ocupacional aprendemos que a pessoa demonstra o que sente, o que quer, o que pensa, o que sabe, não somente pelo conteúdo de suas falas e fazeres, mas também pelas suas formas. Aprendemos a perceber a necessidade de um olhar atento não só para o produto do que o aluno faz, mas para todo o processo envolvido 
na realização das atividades, tais como: o que o aluno faz? como ele faz? para que ele faz? por que ele faz? Falar ou não falar, fazer ou não fazer algo, demonstra algum sentido, algum pensamento, algum saber, alguma necessidade. Enxergar aquilo que está expresso nas entrelinhas das palavras, dos fazeres, das relações .... observar como o aluno se relaciona com os diferentes materiais, objetos, pessoas, espaço físico e situações do cotidiano... descobrir quais atividades são significativas, prazerosas para as pessoas ... construir junto com elas formas possíveis de realização de algo que desejam, adaptando, quando necessário, o conteúdo, a forma, o espaço, o tempo, os materiais ... são competências valorizadas e necessárias na minha profissão.

Acreditar que toda pessoa é capaz de participar das atividades cotidianas, quando respeitadas suas formas possíveis de participação ... acreditar que o investimento afetivo é necessário para junto com a pessoa transformar ações, atividades, idéias, pensamentos, sentimentos e comportamentos destrutivos ou sem sentido, em construtivos e produtivos ... acreditar que toda pessoa é capaz de aprender quando lhe são oferecidas várias possibilidades de agir e construir o seu conhecimento, são algumas premissas desta profissão.

Como pensar e organizar a rotina do aluno na escola, considerando as características e necessidades deste? Como auxiliar a sua organização e relacionamento como as pessoas, objetos, materiais, atividades, no espaço, no tempo, nas ações? Quais atividades podem beneficiar o aluno para este ou aquele objetivo? Como é a psicodinâmica do aluno na realização das atividades? Enfim, como compreender melhor o aluno e suas necessidades no cotidiano escolar para possibilitar caminhos possíveis para o seu desenvolvimento e a sua aprendizagem, são questionamentos que a minha prática profissional sugere para que possamos construir uma educação inclusiva no e pelo cotidiano escolar.

Quero, com estas considerações, salientar que minha formação profissional valoriza e tem como seu instrumento de trabalho as atividades. E, dentre todas, as atividades cotidianas são entendidas como o principal meio pelo qual as pessoas se desenvolvem, aprendem e sobretudo, inserem-se socialmente.

Castro, Lima e Brunello (2001) consideram que:

Assim, com esse campo de novas reflexões e experiências desenvolvidas a partir dos anos 80 , criam-se outras formas de ver o corpo em movimento, em ação em seus 
'fazeres cotidianos'. Outros sentidos são dados às atividades, que passam a ser vistas e valorizadas como elemento articulador entre o sujeito e sua comunidade, representando, assim, oportunidades de encontro e diálogo entre os diferentes indivíduos da sociedade e possibilitando a emergência de produções significativas e desalienadoras, que envolvem um sujeito inserido em determinado tempo e espaço. (p. 45).

Entendendo que estamos submersos na vida cotidiana, a escola e a educação não podem deixar de serem vistas em sua dimensão cotidiana. Para Mello (2003, p.83) “em educação, pensar o cotidiano escolar vem sendo um desafio constante". Para André (2002, p. 39)

[...] o estudo do cotidiano escolar se coloca como fundamental para se compreender como a escola desempenha o seu papel socializador, seja na transmissão dos conteúdos acadêmicos, seja na veiculação das crenças e valores que aparecem nas ações, interações, nas rotinas e nas relações sociais que caracterizam o cotidiano da experiência escolar.

A vivência de situações cotidianas na escola deve ser considerada como um meio através do qual o conhecimento é construído na tessitura das complexas relações estabelecidas neste contexto. Numa visão construtivista, se consideramos conhecimento, conteúdos disciplinares, noções e conceitos desvinculados da vida cotidiana, não conseguiremos compreender a educação como um instrumento para a construção da autonomia e liberdade dos sujeitos, como propõe Piaget (1945/1998).

Relacionada a esta perspectiva, Macedo (em fase de elaboração) constata uma "tendência, muito oportuna, de tratar o cotidiano da sala de aula como uma questão tão importante hoje quanto o ensino de matemática, língua portuguesa, educação física, etc.” Indo além, diríamos que estas disciplinas estão incorporadas em uma disciplina que vamos lidando concomitantemente nas relações com pessoas, espaço, tempo, objetos e atividades na escola: a vida cotidiana. Dito de outra forma, é através da vida cotidiana na escola, a partir das relações que o aluno estabelece com pessoas, espaço, tempo, objetos e atividades que as noções, conceitos e conhecimentos vão sendo construídos. Os conteúdos, os saberes científicos vão sendo apresentados aos alunos em forma de atividades propostas. Por exemplo, ao propor a atividade de observação da formação das nuvens no céu, teremos a oportunidade de que as crianças reflitam de onde será que vem as nuvens? Do que elas são feitas? Podemos pegar as nuvens? Estas são apenas algumas questões que ilustram que os saberes e os conceitos têm que ser apresentados aos alunos na mediação das atividades cotidianas. 
Lembramos que para nós, estas são as que possibilitam que o sujeito se constitua e se reproduza.

Macedo (em fase de elaboração) adverte para a necessidade de desenvolvermos competências e habilidades para lidarmos com questões do cotidiano escolar e segundo ele, os elementos que constituem o real em sua expressão diária, são as relações com pessoas, espaço, tempo, objetos e atividades. Lembramos aqui que para Piaget (1967/2001), o universo é construído na relação do sujeito com os objetos, espaço, tempo que se expressam de modo implicativo ou causal. Portanto, para o desenvolvimento da inteligência, estas relações do cotidiano são condições indispensáveis.

Outra contribuição valiosa para compreendermos a importância de nos debruçarmos ao estudo das relações estabelecidas no cotidiano, diz respeito ao que Ginzburg (1989) denomina de Paradigma Indiciário:

A existência de uma profunda conexão que explica os fenômenos superficiais é reforçada no próprio momento em que se afirma que um conhecimento direto de tal conexão não é possível. Se a realidade é opaca, existem zonas privilegiadas - sinais, indícios - que permitem decifrá-la. Essa idéia, que constituiu o ponto essencial do paradigma indiciário ou semiótico, penetrou nos mais variados âmbitos cognoscitivos, modelando profundamente as ciências humanas." (p. 177).

Para este autor, a cotidianidade é um espaço privilegiado no qual podemos encontrar sinais e indícios que nos permitam melhor compreender uma realidade. É pelo exame dos pormenores, dos fatos muitas vezes negligenciados, que podemos encontrar elementos que nos aproximem da singularidade do indivíduo. Neste sentido, podemos inferir que aquilo que realizamos no cotidiano muitas vezes tornase imperceptível para o olhar externo generalista. Isto é, quando nos atemos àquilo que é mais evidente, deixamos de perceber e valorizar as sutilezas daquilo que nos caracteriza, nos constitui, nos faz desenvolver e aprender.

Para Tedesco (1999, p. 29) "o estudo do cotidiano tem como ponto de partida o sujeito [grifo do autor] enquanto ser particular-individual, suas relações próximas, regulares, intensivas, fixas e mutáveis". Portanto, podemos inferir que se queremos compreender melhor o sujeito - no nosso caso, o seu desenvolvimento e a sua aprendizagem - o estudo sobre as relações que estabelece no seu cotidiano escolar pode nos oferecer sinais e indícios preciosos. 
Finalizando este tópico que se destina a justificar a importância das vivências nas relações do cotidiano para o desenvolvimento e a aprendizagem dos alunos e, por isso, justificar que podemos através destas relações encontrar os elementos centrais para o nosso estudo, temos as seguintes considerações a fazer:

$\neg$ Desenvolver habilidades e respeitar e valorizar as diferenças são processos que vão sendo tecidos e construídos no cotidiano. Portanto, o cotidiano deve ser o foco fundamental de observação e intervenção nas práticas que visam a inclusão social.

$\neg$ Todo sujeito tem o direito de viver o seu cotidiano da forma como lhe é possível, e sem qualquer forma de discriminação. É na esfera do cotidiano que estabelecemos nossas relações sociais e também nossa relação com o tempo, com o espaço, com os objetos e com as atividades. É por viver estabelecendo relações que nos desenvolvemos e aprendemos. Viver o cotidiano é viver desafios e construir caminhos possíveis para a adaptação a cada nova condição e/ou situação.

$\neg$ O que o aluno está fazendo, como ele está fazendo, por que ele está fazendo, para que ele está fazendo, quando ele está fazendo? Como está a participação, interação, localização, orientação, locomoção, compreensão, atenção, interesse, organização, realização, estruturação, reação, reconhecimento, cuidado, responsabilidade, funcionalidade, manuseio, ritmo do aluno nas atividades do cotidiano da escola? Que tipo de auxílio, recursos e adaptações no tempo, na forma, no conteúdo e no objetivo são necessários para que o aluno possa participar do cotidiano escolar, se desenvolvendo, aprendendo e sendo respeitado e valorizado em sua singularidade e em sua diferença? Todas estas questões devem ser reguladoras da observação e reflexão constantes no cotidiano escolar. Todas elas oferecem indícios para compreendermos o desenvolvimento e a aprendizagem dos alunos e planejar ações que objetivem o seu progresso. 


\subsection{Pesquisa construtivista}

Nesta pesquisa de cunho qualitativo, realizamos dois estudos de caso (LÜDKE; ANDRÉ, 1986). Ao longo de oito meses (abril a novembro de 2002) a pesquisadora acompanhou a vida escolar de duas crianças com deficiência de cinco anos de idade, uma com paralisia cerebral do tipo tetraparesia espástica (Érick) e outra com síndrome de Down (Ítalo Júlio). Elas eram alunas de duas escolas de educação infantil do município de Mauá que se encontra na região do grande $\mathrm{ABC}$ de São Paulo. O objetivo deste acompanhamento foi estudar por que e quais relações estabelecidas no cotidiano escolar podem beneficiar o desenvolvimento e a aprendizagem de alunos com deficiência em um perspectiva construtivista e inclusiva de educação. Para isso, elaboramos um roteiro de observação do aluno no cotidiano escolar que norteou a intervenção da pesquisadora nas entrevistas realizadas com os profissionais da comunidade escolar e destes na observação e registro sobre os alunos. A elaboração de instrumentos para o planejamento do trabalho com o aluno considerando suas necessidades e possibilidades de desenvolvimento é uma tendência necessária nas práticas pedagógicas inclusivas como constatamos nos trabalhos de Downing (1996), Stainback e Stainback (1999) e Wise e Glass (2003).

Utilizamos como referência para o desenvolvimento de nosso trabalho enunciados construtivistas. Compreendemos que para a efetivação e realização de uma pesquisa que seja coerente com uma qualidade inclusiva de educação, devemos considerar que o conhecimento é um processo de construção. E, consideramos que realizar uma pesquisa é um processo de construção de conhecimento.

Segundo Garcia (2002, p.46), "talvez a característica mais importante e original da teoria piagetiana do conhecimento (que a diferencia de todas as outras epistemologias) seja considerar a lógica resultado de um processo construtivo [grifo 
do autor]". Portanto, valorizamos no percurso deste trabalho, o que o autor nomeou de Princípio de Continuidade Funcional:

[...] o rechaço das posições empiristas e aprioristas implica, portanto, renunciar à busca de um 'ponto de partida' absoluto para o conhecimento [...] se não há ponto de partida, tampouco pode haver ponto de descontinuidade funcional nos processos cognitivos [...] o princípio de continuidade funcional dos processos construtivos [grifos do autor] do conhecimento, se constitui num dos pilares fundamentais da epistemologia construtivista. Primeiramente, o princípio de continuidade funcional implica a impossibilidade de dar uma caracterização geral intrínseca (sem falar de definição) do que é conhecimento, nem mesmo restringindo-se ao conhecimento científico. Por isso, caracterizamos o conhecimento como um processo que toma sentido num contexto social e cujos graus ou níveis também adquirem significado neste contexto. (p.39-40).

A pesquisa em uma visão construtivista foi discutida ao longo do período da pósgraduação da pesquisadora em vários momentos. Entre eles destacamos: o Seminário ministrado pelo Prof. Dr. Lino de Macedo ao seu grupo de orientandos sobre o tema "Pesquisa em uma visão construtivista" (2001) e na sua disciplina de pós-graduação oferecida no Instituto de Psicologia da USP, intitulada "O possível e o necessário em Piaget e sua contribuição para a aprendizagem escolar". Ambos tiveram na obra "O conhecimento em construção - das formulações de Jean Piaget à teoria de sistemas complexos" de Rolando Garcia (2002) e "Sinais - raízes de um paradigma indiciário" de Carlos Ginzburg (1989) suas principais referências bibliográficas.

Baseadas nestas discussões e aportes teóricos, realizamos esta pesquisa retirando indícios do material empírico adquirido no período de intervenção e coleta de dados para estudarmos o desenvolvimento e a aprendizagem de crianças com deficiência em escolas de educação infantil, nas suas relações no cotidiano escolar.

Durante o período de realização deste trabalho, os seus objetivos, as suas referências teóricas, e todo desenvolvimento metodológico foi sendo modificado e burilado de acordo com as necessidades do processo. Tivemos que realizar escolhas dentre as múltiplas perspectivas que o estudo de um sistema complexo, tal como consideramos o contexto educacional que pretende ser inclusivo, nos possibilita. Estas escolhas foram realizadas levando em consideração as prioridades e possibilidades do contexto estudado, a coerência, a consistência interna do processo, pressupondo uma dialética entre o recorte escolhido e o todo em que se encontrava.

Recortar, em uma visão construtivista de pesquisa, é o trabalho de retirar da realidade fragmentos significativos que sejam indicadores do que se pretende estudar. O que é significativo é aquilo que melhor, dentro de um determinado espaço 
e tempo, pode contribuir para elucidar o problema pesquisado. O recorte implica em selecionar, interpretar e atribuir significados ao material empírico. Este vai ser descrito e organizado subsidiado por conceituações e teorizações em favor dos objetivos da pesquisa.

No processo de realização da pesquisa, procurou-se realizar recortes autônomos em busca de totalidades relativas também autônomas para servir de marco de um trabalho científico.

Consideramos que realizar uma pesquisa deve ser uma prática reflexiva que está a favor do progresso do contexto estudado e dos participantes da pesquisa.

\subsection{Participantes}

Desde 1999, a demanda de crianças de zero a seis anos é matriculada nas escolas de educação infantil de Mauá. Este foi um acordo estabelecido entre o Departamento de Educação Especial do município e a Secretaria Municipal de Educação, Cultura, Esportes e Lazer - SMECE no fim de 1998, como iniciativa em prol dos princípios para uma educação inclusiva. Com isso, tem-se no ano de 2002 cerca de 90 alunos com deficiência nesta modalidade de ensino ${ }^{38}$.

Esse contexto educacional da rede municipal de educação de Mauá ofereceu à pesquisa uma ampla possibilidade de participantes.

A pesquisadora deste trabalho, como uma das pessoas da equipe de apoio da educação especial para assuntos relativos à educação inclusiva, tinha contato com várias escolas e professores da rede.

Nestes contatos, no ano de 2001, ocasião em que se aplicou a versão preliminar do roteiro utilizado como instrumento norteador para a coleta e organização dos dados e intervenção na prática, a professora Marcela da EMEI (Escola Municipal de Educação Infantil) do aluno Érick ${ }^{39}$ manifestou o interesse e disponibilidade em participar da pesquisa por querer ser professora de Érick também no ano seguinte.

\footnotetext{
${ }^{38}$ Este dado foi obtido em fevereiro de 2003 com uma supervisora de educação da SMECE. Até esta data, não havia um documento oficial em que constavam estas informações. Ela o obteve solicitando que cada unidade de trabalho de educação infantil do município lhe enviasse o número de alunos com deficiência que haviam freqüentado esta modalidade de ensino no ano de 2002.

39 Os nomes das escolas, bem como o de todos os participantes da pesquisa foram alterados para preservar a privacidade dos envolvidos. Escolhemos nomear as escolas participantes utilizando o pseudônimo do aluno com deficiência referência na nossa pesquisa.
} 
Ela referiu que dar aula para ele foi um desafio importante, que tinha muita coisa que ela gostaria de compreender melhor e oferecer para o aluno e por isso, gostaria de dar continuidade ao trabalho desenvolvido. Esses foram fatores fundamentais para a escolha desta escola e aluno como participantes da pesquisa, uma vez que o interesse e a disponibilidade no investimento e compreensão do aluno são características importantes dentro de um processo rumo à educação inclusiva.

Ao longo do estudo percebemos que os dados informados pela professora e demais funcionários da escola de Érick não corresponderam somente ao que se observou no cotidiano do aluno em 2002 - ano de coleta de dados. Esta percepção se deve ao fato de que em vários momentos os entrevistados começavam suas considerações dizendo: "Quando ele entrou aqui na escola, ele ...". Consideramos que este fato não invalida a legitimidade da escolha deste aluno, já que estamos falando de processo de desenvolvimento e de aprendizagem que respeita o ritmo individual de cada um. $\mathrm{O}$ recorte do tempo de estudo foi necessário com a finalidade de organização dos procedimentos e intervenções realizadas, mas de maneira nenhuma exclui as informações sobre o aluno dos anos anteriores.

No ano de 2001, a pesquisadora foi referência para apoio à EMEI do aluno Ítalo Júlio - a outra escola participante da pesquisa - através de sua participação nos HTPCs (Horário de Trabalho Pedagógico Coletivo). Esta escola já teve anteriormente alunos com deficiência e a diretora era muito participante e mobilizava constantemente toda a equipe de trabalho da escola para as discussões em torno da educação inclusiva. Este foi um dos critérios utilizados para propor para a escola sua inserção na pesquisa. A diretora indicou a professora Yara que concordou em fazer parte da pesquisa com um de seus alunos com deficiência. Esta professora disse que “apesar de não ter experiência no trabalho com alunos com necessidades especiais, tinha interesse de compreender melhor estes alunos" $"$.

Os alunos e todos os profissionais de cada escola foram considerados participantes de nossa pesquisa assim como a pesquisadora e as mães dos alunos. Consideramos que o professor do aluno, os outros professores e profissionais da escola são os informantes a respeito das relações do aluno no cotidiano escolar. Esta

\footnotetext{
${ }^{40}$ Dados relatados no primeiro encontro realizado com a professora Yara em 05/04. Ver cronograma completo dos encontros realizados no Anexo 4.
} 
escolha implicou na delimitação do número de alunos, professores e escolas para a pesquisa.

Escolhemos como participantes de referência, dois alunos com deficiência cujas relações no cotidiano foram acompanhadas sistematicamente ao longo da pesquisa para um estudo deste processo. Termos uma amostra maior de alunos implicaria na perda da possibilidade de trabalhar com um acompanhamento mais sistemático e com uma metodologia mais voltada para a observação das sutilezas vivenciadas no cotidiano escolar.

A inclusão da professora de sala do aluno, da diretora, da merendeira, do auxiliar de apoio operacional, do vigia, da escriturária, dos demais professores como informantes no processo de coleta de dados, deve-se ao fato de considerarmos que um dos princípios básicos da educação inclusiva é o trabalho cooperativo em equipe, sendo que a comunidade escolar deve estar comprometida com o trabalho desenvolvido com todos os alunos. Isto é, apesar de se ter um professor de referência para o aluno, os demais membros da comunidade escolar também têm um papel educativo fundamental no que é realizado com o aluno na escola. As informações dadas pela comunidade escolar mostraram-se valiosas para a descrição do processo, como veremos na apresentação e discussão dos dados. A professora Marcela, referência do aluno Érick na nossa pesquisa, considerou interessante realizarmos entrevistas junto com os outros profissionais da escola. Segundo ela, "é bom porque eles podem estar dando um relato que às vezes eu não percebo porque já estou acostumada". Não pudemos incluir toda a equipe de profissionais da escola durante todo o percurso de coleta de dados, dada a inviabilidade dentro da dinâmica organizacional da escola para liberar os profissionais sistematicamente para os encontros. Por isso, optamos por ter o professor de sala do aluno como informante principal. Nem todos os profissionais das escolas conheciam e/ou tinham contato com os alunos de referência na pesquisa. Entretanto todos, na medida do possível, participaram das entrevistas coletivas por entendermos que as questões discutidas são instigadoras de reflexão e passíveis de serem generalizadas para outras situações de alunos no cotidiano escolar. Além disso, tiveram a intenção de colaborar para um compromisso coletivo que favoreça uma educação de mais qualidade para todos os alunos da escola. 
Outro critério de escolha dos alunos acompanhados foi que eles tivessem diferentes tipos de deficiência, pois a intenção da pesquisa é explicitar como as relações no cotidiano escolar de crianças com deficiência beneficiam o seu desenvolvimento e a sua aprendizagem independentemente de quais sejam estas deficiências. Foram escolhidos alunos com a mesma idade: cinco anos. Um aluno com paralisia cerebral do tipo tetraparesia espástica e outro com síndrome de Down.

Realizamos um encontro com cada mãe de aluno objetivando apresentar a proposta da pesquisa e coletar algumas informações sobre a relação do aluno com as pessoas, com o espaço, com o tempo, com os objetos e com as atividades no cotidiano de sua casa. Utilizamos como roteiro de entrevista uma versão adaptada do roteiro de observação do cotidiano na escola (Roteiro de Observação do Cotidiano em casa - Anexo 2). Apesar das informações preciosas oferecidas por familiares sobre o aluno, estas foram utilizadas como dados complementares para compreensão dos objetivos propostos na pesquisa. A análise pormenorizada destas informações implicaria em um novo recorte de pesquisa.

Os principais dados gerais dos participantes e os dados da estrutura física e administrativa das escolas serão apresentados a seguir. Esses dados encontram-se sintetizados nos Quadros 1 (p. 79) e 2 (p.81). Entretanto, conheceremos melhor os participantes da pesquisa no capítulo quatro. Neste os dados serão apresentados através de histórias dos alunos nas suas relações cotidianas.

\subsection{1. Érick e sua escola}

Érick tem 5 anos de idade e nasceu na cidade de Mauá. É filho único de Roberto (39 anos) e Regina (38 anos). Seu pai nasceu em São Paulo / SP e trabalha como motorista. Sua mãe nasceu em Andradas / MG e é do lar. Ambos são adeptos da religião Testemunhos de Jeová. A renda da família é em torno de $\mathrm{R} \$ 1.000,00$. O aluno tem paralisia cerebral em decorrência de hipóxia (diminuição de oxigênio) cerebral na hora do parto. Seu quadro motor é do tipo tetraparético espástico. Isto é, apresenta espasticidade (tensão muscular) acentuada nos membros inferiores e superiores. Necessita de um carrinho para sua locomoção e para o seu posicionamento, uma vez que não tem possibilidades de andar e nem de sustentar o 
tronco sem o auxílio deste. Tem dificuldades para utilizar os seus membros de acordo com a sua intenção em decorrência do seu comprometimento motor. Seus braços ficam a maior parte do tempo estendidos e seus dedos fletidos. Como vimos no capítulo dois, seção 2.2.1. é difícil avaliar o nível de sua condição cognitiva, uma vez que ainda não se expressa verbalmente com nitidez e os seus movimentos são sutis. Porém, como veremos na apresentação dos dados, temos indícios que ele tem boa compreensão e possibilidades de desenvolvimento cognitivo. Tem necessidade de utilizar óculos em função de alternar as duas visões (S.I.C.), embora não o use com freqüência. Faz atendimentos de fonoaudiologia, fisioterapia, terapia ocupacional e hidroterapia semanalmente em uma instituição na cidade de Santo André.

Érick estuda na mesma escola desde 2000. Ingressou no maternal e freqüentou no ano de 2002 a fase II, para alunos de cinco anos, com a professora Marcela. A sala de aula em que se encontra o aluno Érick tem 23 alunos $^{41}$. Ele estuda no período da manhã e neste horário tem mais quatro salas de aula em funcionamento na escola, sendo uma de maternal (crianças de três anos), uma de fase I (crianças de quatro anos), uma de fase dois e uma de fase III (crianças de seis anos). São 124 crianças que freqüentam este mesmo período de aula.

A escola tem o total de sete professoras, uma dirigente de escola, uma escrituraria, uma merendeira, duas auxiliares de apoio operacional (estes são os profissionais responsáveis pela limpeza da escola e outros serviços gerais), um vigia $^{42}$. Ela tem quatro salas de aula com capacidade para 32 crianças, uma sala de aula com capacidade para 20 alunos, uma cozinha, dois depósitos (um de limpeza e o outro de alimentos), uma sala para brinquedoteca, uma sala de reunião, uma secretaria, um banheiro para funcionários, quatro banheiros para as crianças, uma pequena quadra, um parquinho, uma área externa descoberta e um pátio coberto, também usado como refeitório. $\mathrm{O}$ acesso do portão principal à porta de acesso para as dependências da escola é através de escada ou de uma rampa. Esta foi construída

\footnotetext{
${ }^{41}$ Desde 1998 o limite de alunos nas salas de aula em que estudam alunos com deficiência é de 28 alunos. Esta escola tem um reduzido número de alunos em todas as salas de aula em decorrência da demanda da região em que esta inserida.

42 Informações a respeito da escolaridade e idade dos profissionais da escola encontram-se no quadro1.
} 
no ano de 2001 para viabilizar o acesso de dois alunos que eram usuários de carrinhos para a sua locomoção, sendo um o Érick.

\section{Quadro 1 - Érick e sua escola}

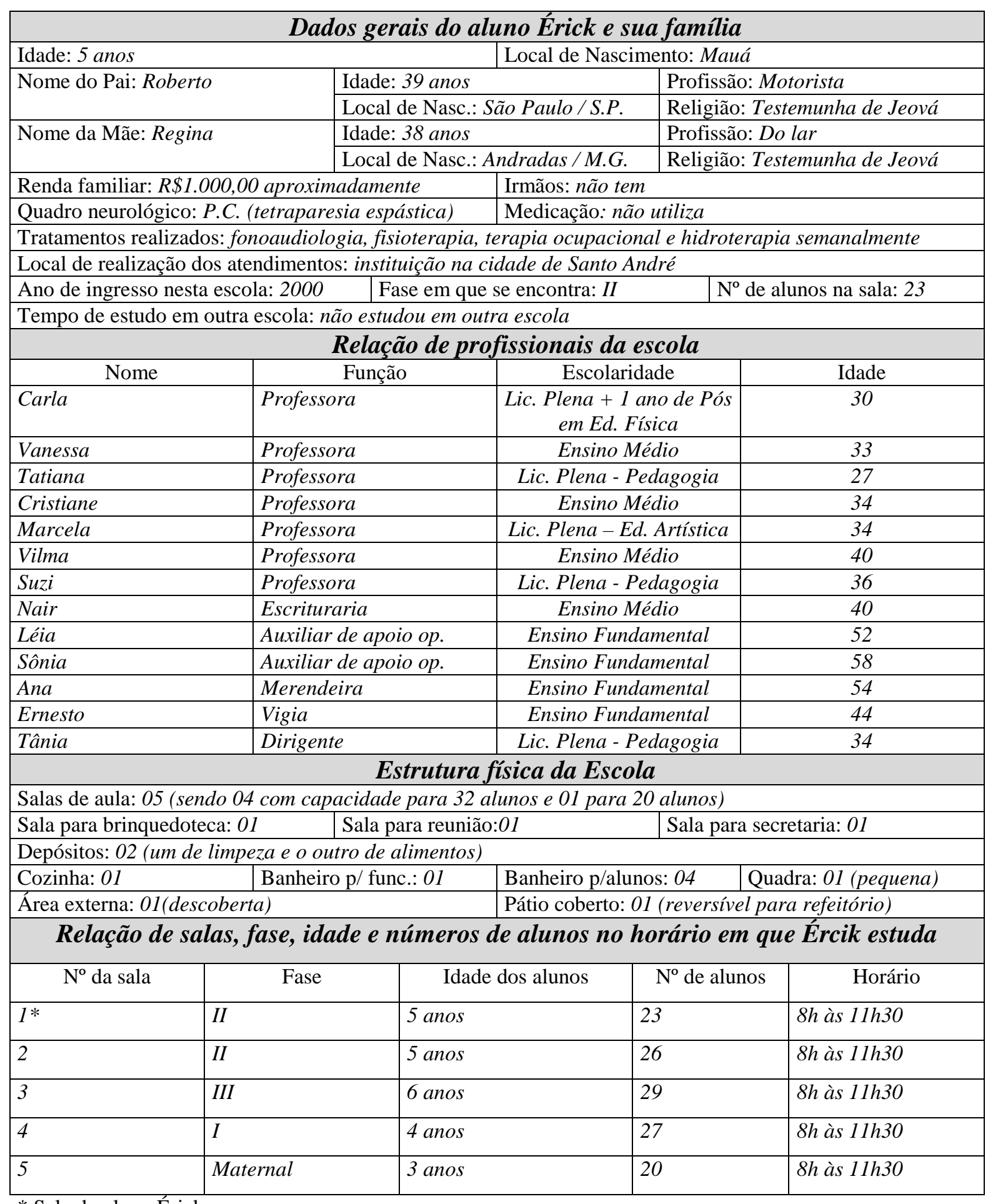

* Sala do aluno Érick 


\subsection{2. Ítalo Júlio e sua Escola}

Ítalo Júlio tem cinco anos de idade e nasceu em São Paulo. Tem uma irmã de 12 anos de idade. Seu pai, Ítalo (34 anos), nasceu em Umuarama / PR e trabalha como comprador no Ceasa. Sua mãe, Neuza (38 anos), nasceu em Bom Conselho / PE e é do lar. Ambos são católicos. A renda da família é em torno de $\mathrm{R} \$ 1.000,00$. O aluno tem síndrome de Down. Recebe atendimentos de fonoaudiologia e pedagogia quinzenalmente numa instituição filantrópica na cidade de São Paulo. Ítalo Júlio entrou nesta escola em 2002. Já havia freqüentado nos anos anteriores duas escolas particulares de educação infantil.

O aluno estuda na fase II para crianças de cinco anos, com a professora Yara. Esta sala de aula tem 20 alunos $^{43}$. Ele estuda no período da manhã e neste horário tem mais três salas de aula da educação infantil. Uma de fase II, e duas de fase III (para crianças de seis anos). A sala de Ítalo Júlio, as duas salas de fase III e uma sala de aula do primeiro ano do ensino fundamental ficam no primeiro andar. No andar térreo fica a outra sala de fase II e uma sala de aula do primeiro ano do ensino fundamental. Não temos os dados das salas de aula da primeira série do ensino fundamental porque elas são de responsabilidade da escola vizinha. A escola de Ítalo Júlio apenas empresta o espaço físico. Fora os alunos da escola vizinha, são 103 alunos que freqüentam este mesmo período de aula.

A escola de Ítalo Júlio tem oito professoras, um professor, uma dirigente de escola, uma estagiária de pedagogia, duas escriturarias, uma merendeira, cinco auxiliares de apoio operacional, um vigia.

A escola tem seis salas de aula com capacidade para trinta e duas crianças, sendo que duas salas de aula são utilizadas pelos alunos da $1^{\mathrm{a}}$ série do ensino fundamental da escola vizinha, uma cozinha, três depósitos (dois de limpeza e um de alimentos), uma sala para brinquedoteca, uma sala de reunião, uma secretaria, três banheiros para

\footnotetext{
${ }^{43}$ A previsão de alunos com deficiência é de um em cada turma. Entretanto, na sala de aula do aluno Ítalo Júlio tem também um aluno com visão subnormal e uma aluna com hemiparesia a direita. Este fato ocorreu porque na ocasião da matrícula os pais não referiram nenhuma deficiência dos alunos. Após o início de frequiência na sala de aula a professora percebeu os déficits nestes alunos. Em discussão com a direção e colegas de trabalho, a professora se disponibilizou a ficar com todos os alunos na sua turma, já que estava conseguindo, apesar da falta de experiência, lidar com todos eles. A direção se comprometeu a não repor as vagas de desistências que ocorram. Ao longo do ano ocorreram desistências nesta e em outras salas de aula.
} 
Quadro 2 - Ítalo Júlio e sua escola

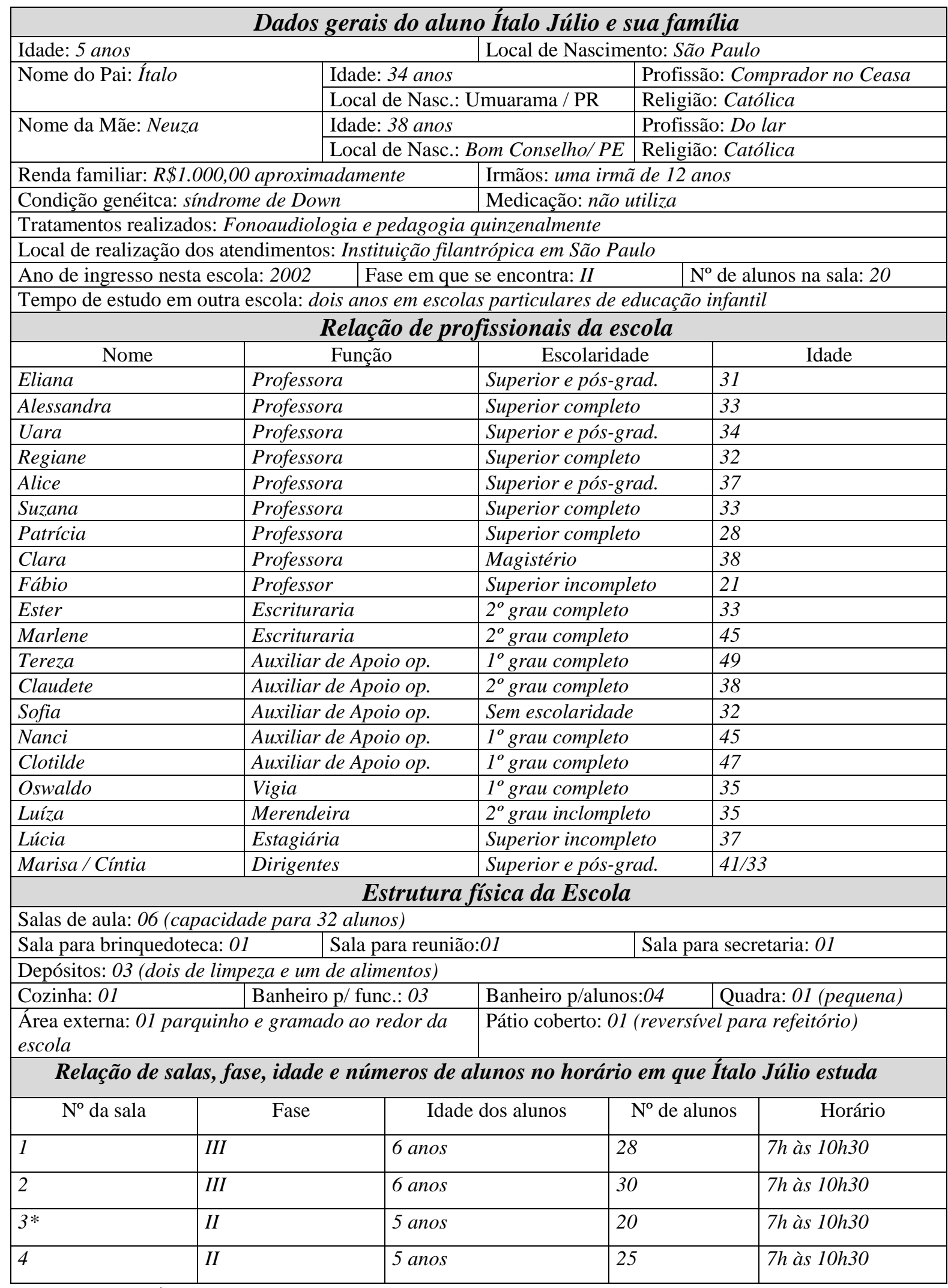

* Sala do aluno Ítalo Júlio 
funcionários no andar térreo, quatro banheiros para as crianças, sendo dois no andar térreo e dois no andar superior, uma pequena quadra, um parquinho, uma área externa descoberta (gramado ao redor da escola) e um pátio coberto, também usado como refeitório.

\subsection{Instrumentos e procedimentos de coleta de dados}

Quando pensamos em quais instrumentos e procedimentos utilizar para explicitar por que e quais as relações estabelecidas no cotidiano escolar podem beneficiar o desenvolvimento e a aprendizagem de alunos com deficiência em uma perspectiva inclusiva de educação, imediatamente surgiu a necessidade de que eles fossem um meio para a busca de informações e simultaneamente um instrumento de intervenção para contribuir no trabalho da escola. Isto é, tínhamos dois princípios fundamentais.

O primeiro está relacionado com a base teórica desta pesquisa: concepção construtivista piagetiana do desenvolvimento e a da aprendizagem; educação inclusiva como um processo em construção que tem as características de um sistema complexo; compreensão de que é através de nossas atividades cotidianas que nos desenvolvemos e aprendemos e que é através da observação destas que podemos retirar indícios que demonstram a forma e o que foi desenvolvido e aprendido.

O segundo princípio diz respeito à compreensão de que a pesquisa, numa visão construtivista, objetiva contribuir para um progresso no contexto em que se pesquisa. O pesquisador não é neutro, tampouco os instrumentos utilizados na pesquisa. Ambos são questionadores de uma realidade na medida em que utilizam experiências e conhecimentos em favor dos propósitos da pesquisa. Esta é essencialmente uma atividade humana. Os dados empíricos são informações geradas pelos nossos órgãos do sentido. Estas informações, adquiridas pela experiência, precisam ser organizadas, interpretadas e atribuídas de significados (GARCIA, 2002). Neste processo estamos intervindo na realidade que pesquisamos. Além disso, consideramos que uma pesquisa que tem como um de seus objetivos contribuir para a construção de uma educação inclusiva, deve utilizar instrumentos e procedimentos metodológicos coerentes com este objetivo.

Assim, elaboramos um roteiro de observação do aluno no cotidiano escolar (Anexo 1) que em si, foi considerado como um dos objetivos específicos da pesquisa. 
O roteiro foi elaborado de modo que explicitasse elementos que nos dessem indícios sobre por que e quais relações no cotidiano beneficiam o desenvolvimento e a aprendizagem do aluno.

$\mathrm{O}$ conceito de Indício foi fundamental na construção do instrumento e nos procedimentos utilizados na pesquisa. As seguintes acepções para este termo nos são relevantes: "o que indica, com probabilidade, a existência de (algo); indicação, sinal, traço [...] marca deixada por; vestígio [...] circunstância que possui relação com o fato [...] possibilitando a construção de hipóteses com ele relacionadas.”(HOUAISS, 2001).

Para Piaget (1936/1987) indício é aquilo que permite fazer uma previsão dos fatos independente das ações concretas dos sujeitos. Em nosso caso, isso significa que podemos pressupor algumas aquisições que o aluno está tendo, não necessariamente de forma direta. Por exemplo, podemos supor que ele está desenvolvendo sua habilidade de se localizar no espaço quando solicitamos a ele que vá na sala da secretaria sem dar todas as coordenadas para que ele execute tal atividade e mesmo assim ele o faz.

Ginzburg (1989) em seu texto "Sinais - raízes de um paradigma indiciário", através de um percurso pela história desde que o homem foi caçador, foi conhecedor de arte, foi detetive e foi analista, aponta que as pistas, os sinais e indícios foram por eles utilizados para decifrar e conhecer uma realidade aparentemente opaca. Estas atividades envolvem operações mentais complexas que configuram ao homem um patrimônio cognoscitivo. O autor mostra a importância de utilizarmos este patrimônio na busca de indícios para compreender o complexo processo de desenvolvimento e de aprendizagem numa educação que pretende ser inclusiva.

Machado (2001) apoiado no conceito de indício proposto por Ginzburg considera que "é preciso sabedoria para lidar com indícios, para buscar o fundamental no particular, para distinguir a sutileza decisiva do pormenor irrelevante. É necessário não fugir das relações subjetivas: afinal, a subjetividade é uma dimensão característica, não é um defeito dos processos de avaliação.” (p.23).

Os conhecimentos da terapia ocupacional também mostram a importância de "lermos" aquilo que está no não dito, no não escrito ... mas que pode estar no olhar, no gesto, no mais sutil movimento, na forma de segurar um objeto, na escolha que 
fazemos das atividades que desejamos realizar, na forma como interagimos com tudo aquilo que realizamos no nosso cotidiano.

Para Piaget (1945/s.d., p.6) "a forma e o funcionamento do pensamento se mostram cada vez que a criança entra em contato com seus pares ou com o adulto: é uma forma de comportamento social que se pode observar de fora". Este mesmo autor (PIAGET, 1937/2001) considera que a elaboração do universo para a criança se constrói nas suas relações com as pessoas, com o espaço, com o tempo e com a causalidade. Por isso, podemos inferir que observar como, quando, por que e para que são estabelecidas as relações da criança no cotidiano na escola expressam o funcionamento de seu pensamento e conseqüentemente o seu desenvolvimento e a sua aprendizagem.

Baseado em Piaget, MACEDO (em fase de elaboração) afirma a relevância de considerarmos as relações no cotidiano com as pessoas, espaço, tempo, objetos e as tarefas escolares como uma disciplina tão importante como o ensino de ciências, matemática, entre outras.

O roteiro de observação do aluno no cotidiano escolar, considerando estas referências teóricas, teve os seguintes pressupostos e propósitos:

$\neg$ ser baseado em questões que têm como objetivo desencadear, no sentido do método clínico proposto por PIAGET (1945/s.d.), olhares para as sutilezas do que é vivido no cotidiano escolar. Isto é, ter questões que desencadeiem um processo de observação e reflexão para que os profissionais possam perceber a perspectiva da criança nas suas relações com os elementos que compõem o cotidiano escolar;

$\neg$ ser um instrumento aberto para a variedade de possibilidades dentro da realidade de cada contexto educativo, podendo se acrescentar ou se retirar questões sempre que necessário;

$\neg$ ampliar aquilo que podemos observar da relação do aluno com pessoas, espaço, tempo, objetos e atividades, contribuindo para regular as relações entre estes elementos;

$\neg$ instigar e criar observáveis para que o professor e demais funcionários da escola possam perceber e questionarem a relação do aluno no cotidiano da escola com pessoas, espaço, tempo, objetos e atividades. Para Garcia (2002) quando nos 
deparamos com uma dada realidade "vemos" dados com certas características. E, quando realizamos uma elaboração conceitual destas, estamos interpretando o dado e portanto estabelecendo observáveis desta realidade. O conceito de observável está relacionado com a teoria de Piaget que valoriza a construção do sujeito daquilo que seus órgãos do sentido captam. Numa visão construtivista, aquilo que se observa está articulado com a teoria do observador;

$\neg$ ser um instrumento de observação para todos os alunos independentemente de suas características físicas, mentais, psíquicas, culturais ou sociais;

$\neg$ favorecer para que o educador, através da observação, possa estabelecer elos associativos com o conhecimento do aluno e com sua conseqüente intervenção no processo de aprendizagem do mesmo;

$\neg$ ser um norteador dos registros e relatórios que o professor elaborou sobre o aluno;

$\neg$ ser um norteador para a pesquisadora nas reuniões com as professoras dos alunos, com os demais funcionários da escola e com as mães deles. Isto é, ele foi um instrumento que orientou a intervenção da pesquisadora nos encontros de coleta de dados;

$\neg$ ser um norteador para a pesquisadora para a organização, apresentação e discussão dos dados.

O roteiro, a partir destes pressupostos, foi dividido em cinco grupos de questões: relações com pessoas, espaço, tempo, objetos e atividades. Esta divisão teve a intenção de ser um recurso de organização do instrumento e de evidenciar a importância da relação com os mesmos. Porém, consideramos que num mesmo fato do cotidiano escolar, numa brincadeira de amarelinha, por exemplo, podemos empreender uma análise expressando a relação com todos estes elementos. Na sua elaboração procuramos detalhar questões relativas a:

$\neg$ o que o aluno está fazendo, como ele está fazendo, por que ele está fazendo, para que ele está fazendo, quando ele está fazendo?

$\neg$ Como está a participação, interação, localização, orientação, locomoção, compreensão, atenção, interesse, organização, realização, estruturação, reação, reconhecimento, cuidado, responsabilidade, funcionalidade, manuseio, ritmo do aluno nas atividades do cotidiano da escola? 
$\neg$ Que tipo de auxílio, recursos e adaptações no tempo, na forma, no conteúdo e no objetivo são necessários para que o aluno possa estar participando do cotidiano escolar, se desenvolvendo, aprendendo, e sendo respeitado e valorizado em sua singularidade e em sua diferença?

Em novembro de 2001, a pesquisadora apresentou uma versão preliminar do roteiro de observação do aluno no cotidiano escolar (Anexo 1) para o grupo de professoras da escola de Érick com o intuito de testar o instrumento que estava em elaboração. A intenção era obter o parecer dos professores e da diretora da escola sobre o instrumento quanto aos objetivos, dúvidas e críticas. A respeito do que as professoras e a diretora acharam do roteiro temos:

Ele não ficou com cara de receita, não é uma coisa padronizada [...]É uma coisa que você precisa observar, observar demais para poder realizar [...] Dá para fazer um relatório completo do aluno, está muito legal [...] Eu acho que isso aí está perfeito. Tem todas as questões que a gente tem que colocar no relatório das crianças [...] É legal a gente ter isso aí desde o começo do ano quando a gente pega a sala, porque aí a gente vai ter uma noção do que a gente precisa estar acompanhando durante o ano. Isso aí não é uma receita, é uma base [...] Um item que eu achei fundamental é esse do que a criança gosta, do que ela não gosta, o que ela consegue fazer ... porque ninguém é igual.

As opiniões das professoras e da dirigente da escola foram fundamentais porque tínhamos como intuito que elas colaborassem na construção do roteiro e assegurou que ele estava atendendo aos nossos pressupostos e propósitos ${ }^{44}$. Algumas professoras desta escola utilizaram o roteiro como suporte para fazer o relatório de avaliação final dos alunos no ano de 2001. Este roteiro também foi utilizado como instrumento de discussão para a compreensão do aluno e suas necessidades educacionais, nas oficinas de formação dos profissionais da rede municipal de ensino de Mauá da SMECE ministradas pela equipe de apoio da educação especial, da qual a pesquisadora fazia parte. A utilização dele foi fundamental para validá-lo como instrumento de intervenção e pesquisa e trouxe indícios importantes sobre a dificuldade que se tem em observar o aluno no cotidiano escolar. Podemos encontrar estes indícios na seguinte fala de uma professora: “tem perguntas que não consegui responder porque percebi que nunca parei para observar direito o aluno, mas que são importantes”.

${ }^{44}$ A versão completa e final do roteiro elaborado encontra-se no Anexo 1. 
A instrução dada ao apresentar o roteiro para o professor de referência do aluno foi que além destas questões o professor fizesse outras que considerasse significativas ao desenvolvimento do aluno. Foi sugerido que ele fizesse um diário registrando fatos, situações, atitudes, falas, comentários, observações e impressões que ele considerava significativos da relação do aluno com pessoas, espaço, tempo, objetos e atividades, colocando a data de cada acontecimento. Uma sugestão de protótipo de registro foi oferecida na forma de um diário de observação (Anexo 3).

Foi proposto ao longo do estudo que os professores respondessem a três questões:

1) Como você descreveria seu aluno?

2) Quais são suas expectativas com relação ao desenvolvimento do aluno?

3) O que você espera que seu aluno desenvolva / aprenda no próximo mês?

A questão 1 foi realizada no início e no final do período de coleta de dados objetivando verificar se na descrição realizada pelas professoras apareceria indícios do progresso do desenvolvimento e da aprendizagem do aluno.

A questão 2 foi realizada no início do período de coleta de dados por se considerar que as expectativas do professor interferem no desenvolvimento e na aprendizagem do aluno. Esta pesquisa não irá pormenorizar esta relação dada a necessidade de recorte metodológico. Porém, considerando que na perspectiva de um sistema complexo as relações são complementares e interdependentes, este dado será apresentado.

A questão 3 foi realizada ao longo do processo de coleta de dados objetivando que o professor, a partir do que observou do aluno no cotidiano escolar, estabelecesse metas no trabalho considerando as necessidades e possibilidades de desenvolvimento e de aprendizagem do aluno.

A coleta de dados e intervenções realizadas com cada professor tiveram como guia o roteiro de observação do aluno no cotidiano escolar. Porém, em cada um dos casos o caminho trilhado foi diferenciado, respeitando:

$\neg$ a possibilidade e disponibilidade de cada professora para trabalhar com o instrumento sugerido;

$\neg$ a necessidade sentida ao longo do percurso da coleta de dados. Tivemos a preocupação com a singularidade de cada caso e de ir planejando as intervenções 
realizadas ao longo do processo e não seguir passos inflexíveis programados previamente à vivência deste. No cronograma da pesquisa de campo (Anexo 4) é possível verificar o caminho percorrido em cada caso;

$\neg$ a compatibilidade de horários de agendamentos dos encontros entre pesquisadora, professora do aluno, diretora e demais profissionais da escola.

Para a entrevista final de coleta de dados, realizadas no $8^{\circ}$ e $9^{\circ}$ encontro com a professora Marcela e no $8^{\circ}$ com a professora Yara, elaboramos um roteiro para nortear a entrevista esmiuçando para cada aluno questões sobre sua relação com pessoas, tempo, espaço, objetos e atividades. Este roteiro foi elaborado após a leitura de todo material das entrevistas transcritos, registros realizados e as atas das reuniões das escolas nos dias em que a pesquisadora participou. Depois desta leitura procuramos formular questões - considerando o processo vivido pelo aluno - para verificar o progresso de cada um com relação aos indícios previamente apontados na coleta de dados. Os roteiros utilizados nas entrevistas finais se encontram nos Anexos 5 e 6. Nestes roteiros apresentamos apenas as novas questões formuladas em cada caso.

As duas entrevistas finais também tiveram as seguintes questões:

1) O que você acha que ele desenvolveu?

2) O que você acha que ele aprendeu?

3) Suas expectativas com relação ao desenvolvimento e aprendizagem do aluno foram alcançadas? Quais? Por quê?

4) Como você descreveria o aluno hoje?

No processo de coleta de dados do aluno Érick, seis registros são transcrições de gravações em aparelho de CD player realizadas durante os encontros. Os demais tratam-se, não especificamente nesta ordem, dos seguintes registros escritos: do encontro realizado entre a pesquisadora e professora; do registro realizado pela pesquisadora da observação que fez do aluno na sua escola; do registro realizado pela pesquisadora de um relato de experiência que a professora juntamente com outros profissionais da escola realizaram no $5^{\circ}$ Seminário de Educação Cultura e Esportes de Mauá, com o título: "Inclusão: uma questão de atitude"; do registro realizado pela professora, baseado no roteiro de observação do aluno no cotidiano da escola; e de duas atas de reuniões em que a pesquisadora participou. 
No caso do aluno Ítalo Júlio, cinco registros são transcrições de gravações em aparelho de CD player realizadas durante os encontros. Os demais são registros escritos dos dois encontros realizados entre a pesquisadora e a professora; da observação que a pesquisadora realizou durante a apresentação do aluno na festa junina da escola, do relatório elaborado pela professora para enviar para a equipe que atende o aluno na APAE; de relatórios elaborados pela professora baseados no roteiro de observação do aluno no cotidiano da escola.

Os registros realizados pela pesquisadora também se basearam no roteiro de observação do aluno no cotidiano da escola.

\subsection{Critérios de organização, apresentação e discussão dos dados}

Para estabelecermos critérios de organização, apresentação e discussão dos dados, todos os registros colhidos durante o processo foram lidos minuciosamente grifando-se os dados que expressassem a relação do aluno com pessoas, espaço, tempo, objetos e atividades e, por conseqüência, que fossem indícios do desenvolvimento e aprendizagem do aluno.

Posteriormente, elaboramos tabelas (Anexos 7 e 8 ) para organizar numa seqüência temporal, as informações que se referiam ao início do trabalho com o aluno $^{45}$, as informações que se referiam ao longo do processo do trabalho e informações referentes a entrevista final de coleta de dados. Os dados foram organizados em seqüências de recortes temporários com o objetivo de explicitar o progresso dos alunos. Chamaremos estes recortes de $1^{\circ}$ período, $2^{\circ}$ período e $3^{\circ}$ período, respectivamente. Os informantes relataram, com frequiência, situações referentes aos três períodos em um mesmo encontro ou relatório. Esta tabela organizada foi dada para a professora de referência de cada aluno para que ela verificasse se havia alguma informação relatada na tabela que não correspondia aos fatos observados e relatados e se tinha dados a acrescentar; para ela visualizar o processo de desenvolvimento e aprendizagem do aluno através de indícios retirados da observação de suas relações no cotidiano escolar; para retribuir a colaboração

\footnotetext{
${ }^{45} \mathrm{O}$ início não se refere ao início do período de coleta de dados, já que os professores relatam situações de períodos anteriores a este.
} 
oferecida no estudo com um material organizado; e para ela e os demais profissionais da escola tomarem ciência das informações que seriam utilizadas na dissertação.

Após as observações realizadas pelas professoras, realizamos nova leitura do material, assinalando exemplos do desenvolvimento e da aprendizagem do aluno e dados sobre a importância das relações no cotidiano em uma perspectiva da educação inclusiva que contribuíram para o progresso do aluno e, ainda, considerações surgidas a respeito dos desafios vividos na construção desta proposta educacional.

Os casos são apresentados de forma narrativa para relatar as relações que os alunos estabeleceram nos seus cotidianos escolares. A intenção é que ao explicitar estas relações, possamos verificar por que e quais foram as relações que favoreceram o progresso do desenvolvimento e da aprendizagem dos alunos. Pretendemos também, que a história dos alunos apresente elementos que exemplifiquem alguns desafios e possibilidades na construção de uma educação inclusiva.

Por considerarmos que as relações com pessoas, espaço, tempo, objetos e atividades se dão e são expressas de forma interdependente no cotidiano, nas histórias, os indícios não estão apresentados divididos por estes elementos. Entretanto, no fim de cada história, faremos uma síntese ilustrativa de algumas relações que os alunos viveram com estes elementos com o objetivo de evidenciar que, embora não possam ser considerados de forma dissociada e independente, eles são categorias fundamentais para a observação e intervenção no cotidiano escolar.

Ao longo da narrativa utilizaremos citações das entrevistas, registros e relatórios realizados pelas professoras e pesquisadora e, também, considerações desta última sobre o material coletado.

Os profissionais mencionados nestas histórias foram identificados por pseudônimos para preservar suas privacidades. Nos Quadros 1 e 2 encontram-se discriminada a função de cada profissional na escola.

Não mencionaremos o tempo todo o período relativo às informações apresentadas. Consideramos que isto tornaria a história cansativa e daria uma característica de linearidade que não é uma intenção nesta pesquisa. Como dissemos anteriormente, os indícios do desenvolvimento e da aprendizagem dos alunos estão apresentados organizados por recortes temporais nos Anexos 7 e 8. 


\section{APRESENTAÇÃO DOS DADOS: Construindo histórias ...}

\section{1. Érick e suas relações no cotidiano escolar}

Érick estuda na mesma escola desde o ano de 2000, quando tinha três anos de idade. Durante os encontros que tivemos com a professora de referência do aluno, com sua mãe e com os demais profissionais das escolas, vários foram os momentos em que eles se remetiam a situações acontecidas em anos anteriores. Todas elas foram consideradas porque, apesar de termos eleito um período de coleta de dados abril a novembro de 2002 - na vivência do percurso escolar do aluno, seria difícil precisar quais eram as informações relativas a cada momento. Além disso, consideramos o desenvolvimento e a aprendizagem como processo, e estes se dão em tempos distintos para diferentes pessoas.

No início da coleta de dados solicitamos que Marcela, sua professora de referência, nos respondesse como descrevia o Érick naquela ocasião. Esta questão teve como objetivo termos uma visão geral de Érick como aluno e, termos informações sobre suas relações no cotidiano que fossem tomadas como dados iniciais a respeito de seu desenvolvimento e de sua aprendizagem. Ela disse que o relatório do fim do ano anterior correspondia ao que descreveria naquela ocasião sobre ele. O relatório realizado pela professora foi subsidiado pelas questões do roteiro de observação que a professora já tinha, devido ao estudo piloto realizado no ano anterior do qual ela fez parte. Segundo este relatório, Érick

\footnotetext{
interage com as pessoas da escola (alunos e funcionários). Comunica-se com colegas da sala, professora e alguns funcionários ensaiando chamá-los pelo nome. Conhece todos os colegas da sala, vibra com músicas e brincadeiras. Presta atenção quando os colegas falam e manifesta seu desejo de comunicação. Reconhece seu próprio corpo, esforça-se para tocar, agarrar e transportar pequenos objetos e brinquedos com as mãos (geralmente a esquerda).

Manifesta sentimentos (alegria, desconforto, timidez) e desejos (sede, fome, brincar e falar) chamando, rindo, chorando, escondendo o rosto, estalando a língua, gargalhando, movimentando as mãos e pronunciando sílabas soltas.
} 
Ainda não escovamos os dentes. Na higiene das mãos assim como na alimentação precisa do auxílio de um adulto sempre que mostra interesse. Na locomoção, a troca de toalhinhas (babador) é auxiliado pelas próprias crianças.

Reconhece sua sala de aula e outras dependências da escola, não possui lugar fixo para ficar (sempre junto com os colegas mudando de mesinhas). Brinca com os brinquedos da escola e já não sente tanta aversão às bonecas.

Como qualquer criança em sua fase sente "ciúmes" de seus pertences e aos poucos percebe a noção de dividir e compartilhar.

Esforça-se para desenhar (marcar o papel) não sente mais "nojo de tinta, cola, areia, etc e procura sentir esses materiais explorando o espaço da folha, da mesa e até mesmo o tato em sua essência.

Vibra na roda de conversa, manifesta-se, observa a rotina.

No almoço alimenta-se razoavelmente (já que fora melhor). Teve contato com pincel, caneta, lápis. Tesoura ainda não.

Participa das atividades no parque (geralmente observando) embora já tenha explorado os brinquedos (com auxílio) e o espaço externo da sala atentando para as limitações e o acesso.

As atividades fora da sala com a integração de outras salas já não o assustam tanto (apenas músicas instrumentais e ensaios coordenados).

Vibra nas rodas de histórias, é capaz de concentrar-se para ouvir e na hora de guardar folhas na pasta é muito divertido observá-lo reconhecendo cada colega com risos e gargalhadas. Nas atividades cantadas, participa ativamente.

A última frase do relatório da professora era: "Foram muitos os progressos, em especial o da socialização e vamos seguindo em busca de muitos outros".

Ao acabarmos de ler, a professora disse: "muita coisa que eu coloquei aí já mudou”. Ela considerava ser importante estar atenta às mudanças, pois: "demora para acontecer alguma coisa, mas quando acontece, vem uma atrás da outra. Então, você tem que ficar ali mesmo, senão você acaba perdendo.” A professora concordou com a consideração da pesquisadora: "um ganho que ele tem, vai desencadeando outros" e afirmou: "vai, vai indo."

A professora Marcela disse que valorizava o cotidiano porque entendia que as relações eram estabelecidas nas coisas que aconteciam no dia-a-dia: "está vendo a relação que está tendo ... são coisas que têm que estar ali presente ... como tem uma história atrás.”

Erick, com o passar do tempo, foi modificando e aperfeiçoando sua forma de interação e comunicação com as pessoas. "Eu acho que ele se desenvolveu bem. Porque antes, para a gente falar com ele ... ele era assim, do tipo envergonhado, ele escondia o rosto, e agora não. Agora se a gente não conversa, ele mexe com a gente, ele brinca, ele pede atenção.” (Ana).

No início ele interagia com as pessoas da escola (alunos e profissionais), porém, como Ana disse, era envergonhado, escondia o rosto. Depois, ficava com vergonha 
só nos primeiros minutos que estava com uma pessoa que não conhecia, depois já ficava descontraído. Quando queria conhecer alguém, ficava olhando e sorrindo até que a pessoa se apresentasse e falasse seu nome.

Suas principais formas de comunicação eram sua expressão facial, seu olhar, seus gestos, movimentos de cabeça, movimentos com o corpo, apontar, tocar, chorar, rir, ficar quieto. Ao longo do processo percebeu-se que ele foi criando novas formas e aperfeiçoando as que já tinha na sua comunicação. "Dava impressão que ele criava um jeito de se comunicar." (Marcela). Para a professora Vilma, "quando uma criança que nem o Érick já se comunica dessa forma é porque ele já sabe se relacionar, da forma dele, mas ele já sabe. Ele encontrou formas para isso."

Marcela conta que, no início, profissionais e alunos tinham dificuldade de compreendê-lo, já que ele não falava. Quando sua mãe dizia para a professora que em casa ele falava algumas palavras, ela chegava a pensar que era coisa de mãe, e que talvez, de tanto ter o desejo que ele falasse, ela acabava ouvindo coisas. Porém, pela observação ela foi constatando que ele emitia alguns sons específicos para determinadas pessoas e objetos. Ela considerava que era a "convivência que trás isso", que mesmo ele não falando literalmente aquelas palavras, com o tempo ela e os demais alunos foram aprendendo os códigos. Marcela tinha o hábito que perguntar e confirmar a hipótese do que ela imaginava que ele queria dizer, com ele. Ela dizia que "muita coisa que aprendeu foi pelas tentativas". Ela perguntava se era determinada coisa que ele queria e esperava sua confirmação pelo olhar, pela sua expressão facial, pelo seu balbucio. Muitas vezes, conversava com a mãe de Érick para associar os acontecimentos da casa dele aos assuntos que iriam tratar na aula, e vice-versa. Isto é, falava de coisas que ele tinha manifestado na escola para verificar se era algo relacionado aos acontecimentos da casa. Isto a ajudava a compreendê-lo e a criar hipóteses para aquilo que ele desejava e pensava. Por exemplo, no dia em que a mãe dele contava que ele assistiu futebol, a professora trazia este assunto para a roda de conversa. E, contava coisas que ele tinha feito na escola para a mãe, para ver se tinha alguma ligação em casa.

Érick ampliou seus balbucios, sons, sílabas e palavras. Cada vez mais eles eram específicos para situações e pessoas diferentes. Falava "alelo" para amarelo, "di" para verde, "Laléla" para Marcela, "Leeeéliia" para Léia, "Ná” para Nair, entre 
outros nomes que tentava pronunciar com mais frequiência, como o de sua mãe. $O$ som que ele chamava a Bruna, sua colega de classe, todo mundo identificava. Ensaiava chamar outros funcionários e pessoas pelo nome. Na roda de conversa criava sons diferentes para cada nome de seus colegas. Repetia o mesmo som para cada nome do aluno quando iam entregar as pastas de atividades deles. Quando ele queria água, ele normalmente estalava a língua. Quando ele queria mais comida, ele olhava para o lugar em que ela estava e confirma com o sorriso após ser perguntado se era aquilo que ele queria. Quando queria voltar para o carrinho em que normalmente sentava, mostrava com o movimento da cabeça virando para o lugar em que ele estava. Quando queria participar de uma brincadeira, ele normalmente sorria. Não se comunicava muito através da fala, mas se expressava com mais fluência. "Já dá para entender muito mais as coisas que quer dizer”. (Ana).

Segundo Marcela, o sinal que ele tinha para dizer que queria água - estalar a língua - surgiu por causa do seu copo que era do Mc'Donalds. Toda vez que passava em frente desta lanchonete ele fazia este movimento também. Foi a mãe de Érick que contou isso para a professora. Com o passar do tempo, quando Marcela perguntava como ele comia as batatinhas no Mc'Donalds ele fazia o movimento da boca para demonstrar.

Os profissionais da escola percebiam que os alunos passaram a entendê-lo melhor. Quando não entendiam, recorriam a Bruna, pois esta entendia bem o que ele quer dizer. Antes recorriam muita à professora Marcela.

Quando chegou na escola, esperava alguém ir até ele para saber qual era a sua necessidade. Depois, não espera mais. Quando queria alguma coisa, utilizava alguma forma de comunicar ao outro o que estava querendo. Quando queria chamar a atenção do outro, se movimentava na cadeira ou gritava. Ficava impaciente quando não era logo atendido pois “não queria perder tempo." (Marcela).

Para chamar a atenção da professora Suzi, quando esta passava desapercebido por ele, fazia "ruaaaaaaaaaaaaaaaa" (ruído do leão), porque fazia parte de uma brincadeira entre os dois. Passou a ser comum ele arrumar uma forma de chamar a atenção de quem desejava: "O dia que você está servindo a mesa ou está tirando alguma coisa da mesa, se a gente não dá atenção ou não falar com ele, ele grita." (Ana). 
Érick aprendeu a conhecer todos os profissionais pelos nomes, assim como o de seus colegas de classe. Quando ia à secretaria, ele pedia para a professora ler a lista dos nomes dos profissionais da escola. Ele emitia um som específico para cada nome que era lido. Quando a professora e outros colegas brincavam de falar o nome errado de cada pessoa, ele reagia com o olhar ou cara feia. Quando ele achava através do olhar a pessoa de quem estavam falando, ele sorria. Um dia ele estava andando de carro com sua mãe e viu o Ernesto - vigia da escola - na rua e avisou sua mãe. Ela parou o carro e deram uma carona para ele. Segundo Ernesto, "ele bateu o olho e me conheceu. Isso é desenvolvimento, né?!"

Marcela considerava que ele sabia quais eram seus colegas de classe e quais eram os alunos da professora Suzi. Esta era uma turma que fazia o mesmo horário de lanche que o dele. Um indício que a professora tinha sobre esta percepção do aluno era o de que quando ia outra turma fazer o lanche com eles, ele ficava olhando para a sala da professora Suzi e apontando como quem estava perguntando: "cadê $a$ professora e seus alunos"? (Marcela). Além disso, ficava inquieto porque percebia que os alunos que estavam com ele naquele momento não eram os mesmos de habitualmente. Quando isto acontecia, Marcela explicava o porque de outra turma estar fazendo o horário de lanche com eles.

Marcela enfatizava que tudo o que acontecia no cotidiano da sala, Érick ia compreendendo gradativamente. Mas, para isso, era sempre necessário explicar a ele o que estava acontecendo, como no exemplo citado acima.

No início do trabalho com Érick, sua professora Marcela e sua colega Bruna eram as pessoas de mais referência para ele. Quando a professora faltava ele ia embora para casa. Porém, a professora foi percebendo que isso não era bom para ele e discutiu com a dirigente e a mãe dele que isto não podia acontecer. Segundo Marcela, "eu não vou ficar com ele para o resto da vida e ele não vai ficar só com esta turma [de alunos] também [...] eu disse à mãe que ela tinha que confiar em todo mundo aqui [...] o aluno não é meu, ele é da escola." Com o passar do tempo, apesar de demonstrar mais afinidade com alguns funcionários, como a Léia, a Sônia, a Nair e a Suzi e ser tímido com as que tinha menos contato, ele ficava com qualquer outro profissional e até com professoras substitutas. 
Com relação aos colegas, ele também tinha suas preferências. Segundo Marcela, a Bruna era uma aluna muito calma, era o "o braço direito, o anjo da guarda" do Érick. Ela sempre o compreendeu muito bem pois ficava muito atenta a ele. Entretanto, a professora foi percebendo que ele estava muito dependente desta aluna e que isto poderia não ser muito bom para a sua integração no grupo. Uma das estratégias que ela adotou para diversificar o contato do aluno com os demais, foi fazer constantemente o rodízio dos alunos nas mesas. Isto é, os alunos mudavam constantemente de lugar nas mesas em que sentavam. Isto oferecia a oportunidade de Érick conviver com os vários alunos da sala. Professora percebia que este rodízio era bom para todos os alunos.

Com relação a integração de Érick com seus colegas, os profissionais da escola consideravam que sempre foi boa, mas que melhorou muito com o passar do tempo. Érick foi ficando mais solto e buscava estar no meio das crianças nas atividades do cotidiano. Seus colegas de sala passaram a ser referência para ele, não dependendo mais exclusivamente da professora Marcela e da colega Bruna, apesar delas continuarem sendo referências importantes para ele durante todo processo. Segundo os profissionais, algumas crianças as vezes tinham receio de chegar perto dele. Quando isso acontecia, a professora Marcela e as outras professoras, arrumavam um jeito de colocá-los junto em algumas atividades mesmo que indiretamente. Elas achavam que era importante ir aproximando-os para eles perderem este receio. Segundo Marcela, "eles estão percebendo que ele não é de vidro, que não vai quebrar". As professoras solicitavam que ela participasse com Érick de algumas atividades junto com os seus alunos para eles irem conhecendo-o melhor. Segundo a professora Vanessa, "os alunos querem se aproximar, se enturmar [...] eles ficam junto sempre conversando, mesmo as vezes sem entender [...] eles não ligam muito para o lado da deficiência, eles não entendem muito bem o que é a deficiência ... porque ele não consegue fazer algumas coisas, mas eles querem estar perto, querem descobrir."

Alguns alunos eram "curiosos" (Vanessa) e perguntavam quando o Érick iria sarar, por que ele não andava ou até mesmo se ele dormia. Profissionais relatavam que era difícil responder a estas questões. Professora Marcela ao falar sobre isso, lembrava da expectativa que a mãe tinha - e que em alguns momentos ela chegou a 
se identificar - de que poderia ser que um dia ele ia acordar e iria estar falando, se mexendo, etc. Ela nos disse: "E você sabe que a gente como professora não é diferente?" Uma forma de explicar a deficiência de Érick para os alunos foi dizer que "ele tem um botãozinho na cabeça que ainda não ligou igual ao de todo mundo". Percebeu que esta explicação não tinha sido muito adequada, quando os alunos iam procurar na cabeça do Érick o botãozinho para ligar. Em nossas entrevistas discutimos a importância de explicarmos aos alunos a deficiência de uma forma simples, objetiva e sem criar expectativas "mágicas" para que ela não existisse mais. Identificamos que esta explicação dada pela professora, também expressava o desejo de todos que a deficiência "desaparecesse" de um momento para outro. A professora Marcela e os demais funcionários perceberam este fato e passaram a trabalhar com os alunos as diferenças de cada um, mostrando que cada um nasce com características diferentes, que cada um tem um jeito para se comunicar, se movimentar e aprender e que precisamos respeitar e oferecer a possibilidade de que cada um faça as coisas do seu jeito.

Os funcionários identificavam que num primeiro momento os alunos se aproximavam de Érick para ajudar e cuidarem dele. Eles perceberam que as crianças o estavam tratando como se fosse bebê. Uma das intervenções da professora Marcela para mostrar aos alunos que ele não era bebê foi retirá-lo do carrinho e colocá-lo de pé ao lado de colegas para mostrar que ele era do mesmo tamanho e tinha a mesma idade que os demais. Chegou a tirar foto desta atividade e desenhar no papel o contorno do corpo de todos os alunos. Marcela percebia que os interesses dele eram da mesma faixa etária dos demais colegas, porque na hora da conversa os assuntos não eram de "nenê" e ele prestava muita atenção nos assuntos do cotidiano. Para sua mãe Regina: "eu acredito que o entendimento dele está bem assim da idade dele mesmo. Ele entende tudinho o que a gente fala."

Antes, os alunos queriam fazer as coisas pelo Érick porque percebiam que ele não estava conseguindo fazer sozinho. A professora Marcela intervinha constantemente orientando-os para ajudá-lo, ensiná-lo e fazer "com ele", mas não "por ele", quando era alguma coisa que ele podia fazer sozinho. Dizia a eles: "temos que deixá-lo fazer tudo o que pode [...] se fizermos tudo para ele, ele não vai aprender." 
No início Érick não gostava muito que as crianças mexessem nele e se recusava em receber ajuda delas para trocar sua toalhinha (amarrada no seu pescoço para enxugar a baba), colocar sua meia ou sapato. Só aceitava que a professora Marcela o fizesse. Esta foi explicando que outros alunos também poderiam fazê-lo e ele foi aceitando que outras crianças fizessem-no. Durante as entrevistas também sinalizamos a importância de Érick participar destas atividades. Discutimos que ele precisava aprender a reconhecer quando a toalha estava molhada e precisava ser trocada. Que isto era um cuidado com ele mesmo que ele tinha condições de ter. Além disso, ele poderia auxiliar os alunos esticando o pescoço e fazendo outros movimentos corporais. No fim do ano estas atividades eram feitas preferencialmente pelas crianças. Antes dos alunos trocarem a toalha, eles perguntavam a ele se já estava molhada, se podiam trocar e pediam seu auxílio. A professora Marcela referia que sempre tinha o hábito de comunicar tudo o que ia fazer com o corpo dele antes de tocá-lo. Ela achava que "as crianças já não o estão vendo mais como deficiente [...] como se fosse assim: se vira sozinho, a gente sabe até onde você consegue!"

Ele passou a buscar o contato com as crianças quando ele necessitava que alguém fizesse algo para ele. A água passou a ser dada pelos seus colegas de classe, que compreendiam com mais frequiência os pedidos do aluno. Érick também buscava o contato com os outros quando queria brincar, quando estava cantando. Quando se mexia ou gritava e não era atendido, chamava a professora Marcela, "tipo assim, Marcela: toma uma providência que eu não estou conseguindo!" (Marcela).

Érick sempre prestou atenção quando os outros falavam. No início ficava muito retraído e "caído" em atividades que parecia não compreender. No fim do ano, Érick compreendia a maioria das atividades e regras do convívio social da escola. Entretanto, às vezes não as respeitava para chamar a atenção. Neste momento era advertido como o fez uma de suas colegas de classe em um momento em que ele estava gritando: "Érick, você não ouviu que não é para gritar? É para todo mundo e para você também!" (Professora Marcela foi quem contou esta passagem). Como era muito observador, acabava sinalizando a professora Marcela quando algum aluno estava fazendo alguma coisa que não era permitido, "assim como dedo-duro". (Marcela). 
$\mathrm{Na}$ roda de conversa ele percebia a seqüência das pessoas falarem e esperava a sua vez. Esperava ser solicitado para manifestar-se. Fazia isso concordando ou não com as hipóteses que a professora formulava para o que ele queria dizer. Às vezes ele não esperava a sua vez. Manifestava-se antes quando queria fazer alguma consideração. Ficava inquieto quando a professora não seguia as atividades da rotina.

Quando começou a frequientar a escola, chorava quando a mãe se despedia. No fim do processo de coleta de dados, ele nem ligava para este fato. Chegava a ficar triste na hora de ir embora, apesar de saber que tinha uma hora de chegar e outra de voltar para a casa.

Às vezes era difícil entender os sentimentos de Érick, principalmente quando ele estava com alguma dor. Com o passar do tempo, com algumas perguntas que faziam a ele, associando alguns fatos relatados pela mãe e pelas observações do cotidiano do aluno, a professora, os demais profissionais e os colegas passaram a entender melhor os sentimentos que o aluno demonstrava. Segundo Marcela, ele era muito emotivo. Chorava quando via cena de filmes que não gostava na televisão. Mudava sua expressão facial ou olhava e abaixava a cabeça quando alguém não fazia o que ele estava esperando.

Quando ele tinha consciência e certeza que ele realmente não queria alguma coisa, passou a fazer um movimento para trás com a cabeça para dizer não. No início do trabalho ele já dizia "dá" quando queria alguma coisa e abaixava a cabeça quando estava na dúvida. Segundo Marcela, o Érick tinha “opinião.” Quando queria pegar alguma coisa, ele insistia muito para conseguir.

No início tinha muito medo, chorava e se assustava em acontecimentos que envolvia muita gente. No segundo semestre de 2002 participou de sua primeira apresentação em uma festa na escola e o público não o assustou. Ele participou acompanhando com os movimentos faciais o ritmo da música, tentando bater a colher (era uma das partes da coreografia da música) e chamou a Nair para movimentar a sua cadeira como faziam nos ensaios. "No começo ele tinha muito medo com essas crianças, medo de festa, medo de movimento. Agora não. Ele faz parte da bagunça. Antigamente quando tinha festa ele começava a chorar, chorava demais, tinha medo do movimento, da bagunça. Agora não. Agora é a felicidade dele." (Léia). 
Érick ficava feliz quando elogiado porque veio com uma roupa ou sapato novo. Tinha ciúmes de um aluno da sala da professora Suzi que tinha paralisia cerebral. Cuspia quando a professora the falava para comer a bolacha molhada no leite. Não gostava de leite. Passou a ficar atento para ver quando ela molhava a bolacha. Se ele percebia que estava com o leite ele se recusava a comer. Sobre esta situação, a professora Marcela comentava a importância da relação de confiança que Érick precisava ter com a pessoa que iria the alimentar para não se sentir "enganado".

Érick passou a beijar as pessoas na escola. No início não conseguia fazer o movimento necessário para isso. A professora disse que sempre o estimulou a fazer isso demostrando a ele o que teria que se fazer para o beijo sair.

Segundo a professora Marcela, Érick gostava muito e passou a movimentar com mais frequiência sua mão e seu corpo principalmente para buscar o contato físico com as pessoas, principalmente com as meninas. Gostava de pegar no rosto e no cabelo delas. "Ele sente prazer de ficar passando as mãos no meio do cabelo ... e as meninas adoram!" Mexia suas mãos também para chamar a atenção da professora Marcela, para avisá-la de algo que estava ocorrendo na sala. Professora trabalhava para ele ter consciência de como o seu corpo estava. O alertava: "se você curvar muito o corpo, você vai acabar caindo!"

Tentava fazer o que os outros solicitavam, com alguns movimentos do corpo. Seus movimentos foram correspondendo um pouco mais à sua intencionalidade e se expandindo. Profissionais perceberam que ele teve um grande progresso com relação a coordenação motora. "Ele melhorou porque quando ele chegou aqui a gente percebia que a mão dele era muito fechada, ele não abria para nada. Aí começamos a brincar com ele e agora ele abre a mão. Ele faz gestos quando me vê, quer mexer a mão. Aí eu falo para ele: faz força para tentar fazer [o movimento de tchau] igual a mim, e ele tenta fazer." (Sônia). "Antes a mão dele não abria, era toda fechadinha. Agora, você manda ele fazer alguma coisa e ele, do jeito dele, tenta". (Ana).

Sua professora Marcela contou que "ele anda mexendo muito [o braço], levantando o cotovelo para cima. Coisa que antes ele não fazia. Era só lateralidade esquerda e direita. Agora está subindo e descendo [...] a gente começou a brincar muito assim: você tem orelha? Então mostra para a gente. E ele levava a mão na orelha..." (Marcela). Além disso, sempre cantavam junto com os alunos a música: "O 
sapo não lava o pé, não lava porque não quer ...". Começou a pôr o dedo no nariz e mexer bastante os pés e as pernas. Tentava usar as pernas em um movimento de vai e volta quando estava na balança. Sua professora percebia que "ele tem noção do esquema corporal [...] ele sabe onde fica cada parte de seu corpo. Você pede e ele manifesta". Se ele estava deitado no chão, ele tentava virar o seu corpo para mexer em alguém, para chamar a atenção do outro ou para mexer em alguma coisa, assim como seu braço e sua mão. Passou a se esticar e a movimentar muito no seu carrinho. Quando estava sem o apoio de peito, parecia até que ia cair. Parece que foi descobrindo a possibilidade de movimentar os membros do seu corpo. A professora considera que o seu "feed-back" para respostas motoras passou a ficar muito mais rápido, tanto para os movimentos de abrir e fechar a mão esquerda, quanto para levantar a cabeça, quanto para abrir e fechar os braços, quanto para pôr a mão em alguma parte do corpo quando solicitado e tentar utilizar a mão direita.

A professora Marcela foi estimulando para que ele começasse a usar sua mão direita para segurar o papel. Antes ela prendia este com durex. Ele tentou durante um tempo, mas depois desistiu. E mesmo quando a folha estava pressa com durex, ele fazia de tudo para derrubá-la. E a professora pensou na hipótese dele estar fazendo isso para poder desenhar também do outro lado da folha como os outros alunos faziam.

No fim do ano a professora Marcela começou a fazer a brincadeira de deixar a mão esquerda dele pressa no estojo em que guardava seu giz-de-cera. E dizia a ele: "se vira para tirar". Ela fazia isso porque percebia que ele estava com condições de fazê-lo. Ele conseguia, com certo esforço, tirá-la do estojo com o auxílio da mão direita.

A professora Marcela achou que a aplicação de botox ${ }^{46}$ que o aluno realizou no início de maio de 2002 ajudou a mão "a ficar mais mole" e por isso, contribuiu na sua movimentação. Entretanto, ela percebeu que por estar mais mole, ele

\footnotetext{
${ }^{46} \mathrm{O}$ botox é uma substância aplicada diretamente na musculatura para tratar desordens neuromusculares que produzem a sua contração involuntária, no caso de Érick, sua espasticidade muscular. Durante o período de ação da medicação, que tem mais ou menos duração de três a quatro meses, o objetivo é diminuir a tensão muscular e exercitar a musculatura para que ela consiga realizar movimentos voluntários que uma vez conquistados, tenderiam a se manter mesmo após o fim do efeito da medicação no organismo. Um dos efeitos iniciais da aplicação do botox é trazer uma fraqueza provisória da musculatura. (NEUROLOGY CHANNEL, www.neurologuchannel.com/botulinum/index.shtml).
} 
inicialmente teve dificuldade de apreender os objetos em sua mão. Mas, com o passar do tempo esta preensão foi melhorando. Tentava com sua mão (abrindo-a e fechando-a) pegar o giz de cera que queria. Quando o giz caia da mão, colocavam o de volta. Era necessário alguém segurar o estojo para ele poder realizar este movimento. Segurava o giz de cera pressionando-o entre os dedos na pontinha da mão próximo ao polegar. Virava a mão para posicioná-la de um jeito que favorecia o seu movimento. No início do trabalho com o aluno o giz de cera era encaixado na mão do aluno e era o movimento do braço que fazia com que riscasse o papel. Sua mãe Regina fez giz de cera colorido em formato de quadrados para ele utilizar na escola, pois no início facilitava sua preensão. Depois, além destes gizes, que chamavam de "tijolinho", ele também passou a querer utilizar o giz de cera redondo que os demais alunos usavam. Segundo sua professora ele ficava observando o giz de cera dos colegas e olhando para o seu. Quando ela perguntou se ele também queria usar aqueles ele respondeu que sim.

Érick utilizava um pincel com cabo mais grosso ou pincel tipo trincha para pintar. Marcela relata que foi legal o fato de o aluno necessitar utilizar este tipo de pincel, pois “foi uma adaptação para o Érick que a sala toda também quis usar." Ela pediu para todas as mães trazerem trinchas e pincéis de cabo grosso. Isso foi bom porque ela achava que nem todo mundo precisava usar o mesmo pincel. E, com uma variedade de tamanhos os alunos podiam escolher utilizar aquele mais adequado para o desenho que estavam pintando.

A professora Marcela foi trabalhando para que Érick segurasse a colher com a mão esquerda prendendo-a entre seus dedos e tentando levá-la a boca. Quando o seu cotovelo estava estabilizado (a professora segurava o cotovelo dele com sua mão), ele fazia o movimento de levar a colher até a boca. Porém, como não conseguia coordenar vários movimentos juntos (flexão e preensão dos dedos, flexão do antebraço, abrir a boca, introduzir o alimento) ele derrubava a comida antes de chegar à boca. Porém, Marcela segurava na mão do aluno e fazia o movimento junto com ele. Discutimos em nossas entrevistas a importância deste tipo de atitude da professora. Assim como a dela segurar no braço e na mão dele para que ele fizesse o movimento de várias atividades, como a de descascar a banana. "Eu ponho a mão dele na casca da banana e faço o movimento para baixo [...] quando terminou, eu ponho toda a 
casca na mão dele e seguro o lixo para ele jogar; ele estica a mão para jogar, mas abre a mão e a derruba antes do tempo." Marcela estava tentando fazer com que ele segurasse o pão na mão para ele mesmo levá-lo até sua boca. Embora ele ainda não estivesse conseguindo fazer, porque ele tinha dificuldade de coordenar o movimento de levar o braço até a boca, abrí-la e mastigar, ela via possibilidade dele aprender porque ele já estava conseguindo chegar com o pão até a boca. Professora percebeu que ele também estava babando menos. Algumas crianças já estavam aprendendo a dar pão e bolacha na boca dele para ele comer. Marcela nos contou que no início também tinha um certo receio de dar comida para ele e trocar a sua toalhinha porque ele babava: "não vou mentir, você fica meio receosa de estar colocando a mão [...] tem cheiro de baba". Com o passar do tempo ela não se incomodava mais em fazer estas atividades e nem os colegas que auxiliavam nesta atividade.

Antes e depois do lanche, lavavam as mãos. Depois do lanche, também era realizada a escovação dos dentes. No início do trabalho com o aluno, Marcela percebeu que ele observava muito os colegas escovando os dentes. Esta era uma atividade da rotina que ele não realizava. Ela tinha a impressão que ele gostaria de realizar esta atividade e chegou a propor que um dos seus objetivos do trabalho com o aluno fosse introduzir esta atividade na sua rotina. Em nossas entrevistas chegamos a conversar sobre algumas possibilidades desta atividade ser realizada. No fim do período de coleta de dados, Marcela nos disse que "esta foi uma necessidade que ficou evidenciada mas não fizemos ainda". A justificativa da professora foi que "eu morro de medo dele engasgar [...] ele não sabe cuspir". Professora achava que nesta época ele já não sentia mais necessidade de fazer esta atividade.

Érick folheia a revista tentando segurá-la com a mão direita e virar com a mão esquerda. A professora ou os colegas necessitavam estar próximos a ele principalmente para auxiliar no apoio para fixar a revista enquanto ele virava a página. Marcela disse que trabalhou muito com os alunos para serem pacientes e não virarem a folha por ele. Ela dizia: "o Érick é mais lento, mais ele precisa tentar fazer sozinho".

No segundo semestre de 2002 todos os materiais da escola eram oferecidos ao Érick. Segundo a professora Marcela, "ele não tem coordenação para usar a tesoura, mas a tesoura vai na mão dele". A primeira vez que ele segurou a tesoura, 
ele a levou na boca, mas com o passar do tempo, embora ele não conseguisse fazer o movimento adequado para utilizá-lo, dava para ver os seus músculos mexendo com a intenção de realizar o movimento.

Érick se recusava a entrar em contato com tinta, cola, areia, entre outros materiais que "melecavam" ou que sujavam. Sentia aversão a eles e por vezes ânsia. Com o contato gradual e constante com estes materiais, e a explicação que após o seu uso as partes que estavam sujas seriam limpas, ele passou a utilizá-los sem receio. "Quando ele está com a mão suja ele vem mostrar para a gente [...] ele fica feliz em mostrar que a mãozinha está suja de tinta." (Ana). Segundo Marcela a mãe de Érick fica contente quando ele volta sujo para casa, "porque está acontecendo coisas com ele que acontecem com todas as crianças". Por este mesmo motivo, sua mãe também ficava contente quando a professora dizia que o filho tinha levado bronca e tinha pegado piolho.

No início do trabalho com o aluno ele sentia aversão de bonecas. Com o passar do tempo, começou a não se incomodar mais quando as crianças estavam brincando de boneca ao seu lado, embora continuou não querendo contato físico com elas. Professora Marcela achava que estava relacionado com a associação que ele fazia entre bonecas e bebês. Porque com estes, ele ficava observando de longe, não demonstrando interesse pelo contato físico. Ele também ficava retraído com a figura de papai-noel e árvore de natal. Mas passou a aceitar vê-los de longe.

Érick sentia muito ciúme de seus pertences, não deixava ninguém pegar sua mochila, lápis, etc. Quando isso acontecia ele gritava. Assim como ficava bravo quando seu sapato caía e alguém dizia que ia pegá-lo. Professora Marcela foi gradativamente trabalhando a noção de dividir e compartilhar os materiais, e sempre o avisava quando iria pegar algum material seu e em qual lugar iria guardar depois. Segundo ela, ele era egocêntrico como as crianças da idade dele, mas quando era avisado para o que e quando iam mexer nos seus pertences, ele passou a não se incomodar mais, embora sempre ficasse muito atento a eles. Ele sabia o que era dele, o que era da escola e quais eram os materiais de uso coletivo. Às vezes tomava conta do material da professora a pedido dela.

Érick sabia em que lugar se guardavam os objetos do seu uso cotidiano na escola e dos demais alunos. Sabia onde era sua sala de aula, e todas as demais dependências 
da escola. Segundo os profissionais isso era facilmente identificado através do olhar e gestos do aluno quando era perguntado sobre estes locais, quando indiretamente alguém estava falando sobre eles ou quando as crianças demoravam para levar o material que seria utilizado até ele. Marcela diz que se eles estão no parque e fala: “olha a pipa", ele logo olha para o céu rasteando até encontrá-la.

No início do trabalho, ficava a maior parte do tempo no seu carrinho. Locomovia-se com alguém o empurrando. Quem fazia isso normalmente era a professora Marcela ou outro adulto. Com o passar do tempo as crianças é que eram responsáveis por empurrar o seu carrinho, aprenderam a subir alguns degrauzinhos que a escola tinha. Em lugares mais acidentados, a sua professora ou outro adulto era quem dirigia o carrinho.

Sua professora o questionava em que lugar ele gostaria de ficar. Por vezes ele manifestava querer andar no colo da professora, às vezes queria ficar sentado no chão com ela, às vezes deitado no chão (principalmente quando iam para a sala de vídeo). Professora acha que neste momento ele tinha dúvidas sobre qual era o melhor lugar para ele. Pois, apesar de parecer que ele compreendia que para prestar atenção no filme era melhor ele ficar no carrinho, por outro lado, ele queria ficar ao lado das crianças, "deitado no chão como eles". (Marcela).

Érick pedia seu tampo de mesa para o carrinho quando percebia que seria realizada alguma atividade nesta. Seu carrinho ficava encaixado na mesa com os demais colegas, e ele mudava constantemente de posição (assim como os demais alunos) mas nunca ficava de costas para a porta e nem para a professora, para ele poder ver o que estava acontecendo com ele. Na roda da conversa, ficava sem o tampo do carrinho para ficar com os braços livres. Às vezes ele ia no seu carrinho até o alto de um morrinho de terra e grama do parquinho. Toda vez que queria ver alguma coisa que estava longe dele ou quando alguma coisa nova estava acontecendo, ele solicitava que alguém o levasse para ver. Depois que via, se contentava e parava de olhar, apontar ou emitir alguns sons na direção do que queria.

A rotina da escola era conhecida por Érick. Demonstrava isso porque vibrava a cada sinal que a professora dava de solicitação de mudança de atividade ou com o movimento dos colegas de pegar a mochila, pegar a toalha para ir ao banheiro, pegar o caderno para por bilhete, entre outras. Quando a professora pedia aos alunos para 
arrumarem a bolsa e material, ele solicitava para algum colega pegar a sua mochila e colocá-la em cima do seu carrinho. Quando na roda da conversa o grupo estava definindo a seqüência das atividades que seriam realizadas no dia, ele mostrava o cartão correspondente que estava na sua mão na hora adequada. A professora percebia através do olhar dele para os cartões das atividades da rotina, pelo seu olhar atento para a sequiência das atividades que foram colocadas na lousa ou pela sua inquietude, que ele reconhecia quando no dia tinha ficado alguma atividade sem realizar. Ele sabia qual era a hora do dia que iriam trabalhar com o calendário. Demonstrava este conhecimento pelo direcionamento de seu olhar e gestos ao calendário no horário adequado.

Ficava impaciente quando chegava a hora de comer. Sentia o cheiro da comida e percebia que já era hora da merenda. Ele demorava mais tempo para comer que seus colegas, embora ele foi comendo mais rápido com o passar do tempo. Quando ele percebia que seus colegas tinham terminado ele tentava comer mais rápido para acompanhá-los.

Ele realizava as atividades de rotina mais ou menos no tempo planejado, respeitando as suas características. Quando ele considerava que já tinha terminado uma atividade, desenho em folha, por exemplo, não adiantava dizer a ele que tinha mais tempo ainda para continuar, porque para ele já tinha terminado.

Érick acompanhava o ritmo nas brincadeiras de palmas e também tentava bater as pernas. Ele acompanhava a contagem com o movimento da boca e no mesmo ritmo que os demais alunos. Se parassem de contar repentinamente, ele sabia continuar na sequiência adequada sem necessitar de acompanhamento. Uma das atividades da rotina em que isto era muito praticado era a brincadeira do pimpão. Esta era uma brincadeira em que as crianças ficavam sentadas lado a lado em círculo. A mão direita de uma criança ficava em cima da mão esquerda da criança que estava ao seu lado direito. E, sua mão esquerda embaixo da mão direita da criança que ficava ao seu lado esquerdo. A brincadeira consistia em contar alto até chegar no dia do mês. Enquanto contavam, a mão direita de uma criança batia na mão esquerda da outra e assim sucessivamente até chegarem no número correspondente ao dia do mês. Érick acompanha com muita atenção a contagem. Percebia-se isso através do seu movimento com a boca e seu olhar que ia seguindo aluno por aluno. Quando chegava 
a sua vez, ele movimentava o seu braço para dar a mão direita, e depois movimentava o braço esquerdo para dar a mão esquerda. Esta era uma atividade que fazia parte da rotina que tinha como objetivo trabalhar seqüência temporal, quantidades, dia do mês e lateralidade. Esta era uma noção que a professora percebia que alguns alunos ainda não tinham, mas que Érick já tinha desenvolvido. A professora não tinha certeza se ele sabia que o nome dado era direita e esquerda, mas percebia que ele sabia o que era para cima, para baixo (levantava e abaixa o braço quando solicitado), para frente e para trás (olhava para o lado correspondente também quando solicitado). Também conhece as noções dentro, fora, tirar, por, quente e gelado, doce e salgado. Ana considerava que ele tinha estas últimas noções porque "ele adora maçã, canjica e arroz doce ele come. Ele sabe que isto tem um gosto diferente da bolacha água e sal."

Érick inicialmente não tinha muito interesse em pegar o giz de cera para desenhar na folha em branco. Contentava-se e gostava muito de ver os colegas pintando. Quando o fazia, se interessava principalmente em utilizar o giz laranja e depois o giz verde. Depois passou a se interessar em pintar na folha, mas a professora percebeu que era necessário um ponto de referência para ele. Como ele não conseguia estruturar um desenho, Marcela considerava necessário fazer algum contorno de desenho prévio, pois assim, ele se estimulava mais para querer pintar sobre este. Passou a usar várias cores, e quando a professora ia solicitando pelo nome delas ele pegava adequadamente os objetos de cor amarela, verde, laranja, azul, vermelha e preto. Ela não tinha certeza se ele conhecia as outras cores. Anteriormente a este momento, a professora precisava levar apenas duas opções de cores bem próximas a ele para que escolhesse qual iria utilizar. Ele sabia que havia uma seqüência nas atividades em folha que eram realizadas e entendia que depois elas seriam guardadas em sua pasta. Gostava muito de rever as atividades em momentos posteriores. $\mathrm{O}$ produto da sua atividade em folha passou a ser riscos que realizava com movimentos de cima para baixo e de baixo para cima para preencher o desenho realizado pela professora ou por outro aluno. A professora percebia nitidamente a intencionalidade dele em pintar o desenho. A marca no papel logo após que fez a aplicação do botox ficou bem clarinha porque não tinha muita força para segurar o giz de cera. Mas, após algum tempo, passou a ficar um pouco mais forte o seu risco. Para desenvolver 
a coordenação motora e a noção espacial de Érick, Marcela procurava fazer o desenho de referência em vários pontos da folha, principalmente do lado direito para estimulá-lo a levar o braço/mão esquerda até este lado. Ainda não tinha conseguido realizar exercícios de ligar um ponto ao outro.

Para pintar com tinta, os colegas necessitavam segurar o pote para que Érick pudesse molhar o pincel na tinta e depois pintar no papel. Tinha noção de quando pegou muita ou pouca tinta. Ele passou a não se preocupar mais com a sujeira que faria pois sabia que depois tudo seria limpo. Antes se incomodava e até se recusava em realizar esta atividade.

Érick gostava de pintar o quadradinho do dia correspondente no calendário. Um colega o auxiliava mostrando qual era o local dele pintar. A professora Marcela tinha dúvidas se ele sabia identificar sozinho qual seria o número correspondente ao dia que ele deveria pintar, porque ele tinha dificuldade de coordenar o movimento para apontar com o dedo. Discutimos algumas formas e materiais alternativos para a professora estar trabalhando este conhecimento com ele.

Érick ficava muito atento ao movimento de tudo o que acontecia na sala. Se a professora pedia para os alunos trazerem algum material de casa, ele cobrava a mãe. “Ela [mãe de Érick] falou que ele estava cobrando ela [para trazer um um pote de vidro vazio, para fazer a atividade do dia das mães], quando ele trouxe ele foi logo mostrando". (Marcela). Na realização desta atividade, a proposta era fazer uma florzinha com massinha para colar no vidro. Quando estava fazendo a florzinha para o Érick, Marcela se advertiu: “Mas, caramba ... a florzinha foi eu que fiz, não foi ele!" Aí ela resolveu pedir a mão dele para que ele apertasse a bolinha do miolo da flor no pote de vidro: "Érick, vamos fazer uma bolinha, vamos pôr um dedinho aqui e amassar. Aí ele veio com a mão esquerda, me mostrou o dedinho e eu peguei na sua mão e falei para apertarmos [...] a bolinha ficou bem funda, com a marquinha da unha dele".

A pedido da professora Marcela, Érick associou figuras da revista com pessoas do seu convívio na escola. "Eu achei interessante porque ele encontrou uma loira que tinha cabelo curto na revista. Perguntei se era a Léia, e ele falou que não. Aí eu disse que parecia com a Cristiane, e ele concordou". A professora achou isso 
interessante, porque esta professora era uma com a qual ele menos tinha contato na escola, mas mesmo assim ele conseguiu associar.

Marcela também se admirava porque ele ria das piadas que ela fazia com ele ou com os outros alunos, mesmo quando ela não estava falando diretamente com ele. Para ela, era um sinal que ele estava compreendendo o conteúdo das piadas. A compreensão e atenção do aluno sempre foram reconhecidas e valorizadas por todos os profissionais da escola.

Ele se manifestava (levantando a mão, com gestos ou balbucios) quando perguntavam para o grupo de alunos alguma coisa que ele sabia. Se perguntavam: quem é menino? Ele levantava a mão como os demais. Quando não sabia responder, ficava atento o que algum aluno iria responder e depois também se manifestava. Demonstrava compreender que quando a professora pedia o caderno deles, iria um bilhete para sua mãe. Ele logo olhava para sua mochila e "ficava eufórico". Se os outros alunos ganhavam bilhete e ele não, ele ficava impaciente tentando mostrar para os outros que estava faltando alguma coisa.

Todos os alunos da sala de Érick tinham um dia para ser o ajudante da professora. Marcela percebeu a necessidade de Érick também ser. Um colega empurrava seu carrinho e ele ia passando para entregar os materiais para os alunos. Gostava de entregar a pasta de materiais para os alunos e emitia um som específico para cada um deles.

Quando as crianças realizavam alguma atividade que ele não podia fazer naquele momento sem o auxílio de alguém (como ficar pondo e tirando areia dos potes, derrubando o que haviam construído), ele observava atentamente as crianças brincando e segundo Marcela ele se divertia com isso. Ele prestava muita atenção nos filmes e programas que assistia na televisão. Ele ficava na roda enquanto as crianças brincavam de jogo da memória. Marcela percebia que ele sabia que tinha regras e uma seqüência a ser seguida no jogo, mas não tinha certeza se ele sabia que o objetivo do jogo era encontrar as duas figuras iguais. Independentemente de estar jogando, ele comemorava junto com os demais quando algum aluno achava o par igual.

Sua mãe deixou na escola um teclado de computador para que ele brincasse e começasse a reconhecer as letras. A professora percebia que ele reconhecia a letra 
"E", mas as outras ela não sabia responder uma vez que na sala trabalhava com as crianças o conjunto das letras, e não as letras isoladamente.

No início do trabalho com Érick, as crianças iam brincar de casinha e faziam de conta que iam dar chá ou comida na boca dele. Ele ficava bravo assim que percebia que não tinha nada no recipiente. Depois de um tempo, esta passou a ser uma das brincadeiras prediletas de Érick. Ficava muito atento e se preparava com o movimento da boca para esta etapa da brincadeira. Quando estavam brincando de pantomima, Érick tentava movimentar o seu corpo para fazer esboços dos gestos do objeto ou animal que teriam que representar.

Os colegas de Érick o procuravam para brincar. Eles o orientavam para colocar a mão nos lugares adequados nos brinquedos, tentando estimular para que o aluno percebesse e compreendesse tudo o que o brinquedo podia fazer. Professora Marcela orientava os alunos que se tivesse brincadeiras que seriam difíceis do aluno participar por causa das barreiras físicas, eles tinham que pensar uma forma de levar a brincadeira até o Érick.

Profissionais relataram que no começo Érick não gostava muito de ir nos brinquedos do parque, parecia que tinha medo. Preferia ficar apenas observando as crianças. Embora tivesse um pouco de medo de uma árvore que tinha no parque, gostava de ir no colo da professora próximo a ela, pois era um bom local para observar os demais alunos. Depois de um tempo passou a ir com freqüência na balança, gira-gira e tanque de areia. Pedia com insistência para ir nestes brinquedos. Tânia achava que o que Érick mais gostava na escola era o parque.

Marcela contava que Érick também gostava muito das atividades de música (acompanha ativamente o ritmo com balbucios e movimentos de sua boca), de roda, de ouvir histórias, de brincar de pega-pega, esconde-esconde, barra-manteiga com os demais alunos. Nestas atividades, os alunos ou professores eram quem empurravam o carrinho de Érick. Era freqüente duas salas fazerem o mesmo horário de parque ou lanche. Isso facilitava o trabalho das professoras, porque quando era necessário dar uma atenção mais específica para o Érick, o outro professor, ou até mesmo outro profissional da escola, auxiliava na coordenação do trabalho com os demais alunos. Profissionais relatam que a questão do apoio entre a equipe sempre esteve muito presente naquela escola. Sua professora dizia que a escola tinha algumas dificuldades 
no espaço físico da escola, mas que contava com a ajuda de todos os profissionais da escola e dos alunos. Segundo Sônia, "tem que ter o apoio de todo mundo, se não, não dá!". Marcela em uma das entrevistas iniciais nos disse que uma outra dificuldade que tinha era a de administrar o tempo para dar atenção ao Érick e ao mesmo tempo não deixar os alunos sem referência. A supervisora desta escola chegou a perceber que o planejamento da sala de aula estava muito voltado para atividades com o aluno Érick e questionou a professora se não seria necessário refazê-lo e se certificar que ele estava de acordo com a necessidade de todos os seus alunos.

Marcela considerava que o que ele mais gostava da escola era do grupo de alunos. Considerava que ele gostava muito de freqüentar a escola independente do espaço físico em que se encontrava e da atividade que estava sendo realizada. Ele gostava muito do contato físico com as crianças e de estar no meio delas.

Os profissionais da escola percebiam que quando Érick entrou na escola sua mãe era muito insegura, era resistente e tinha medo por não saber se a escola seria boa para ele. Foi só no ano de 2002 que parecia que ela estava mais tranqüila. Segundo Marcela, "ela está super animada. Esta parte da insegurança que ela tinha, como: vão machucar meu filho, não vão cuidar bem dele, vão deixar ele passar fome [...] parece que isso ela já deixou de lado.” A mãe o levava para aula mesmo nos dias em que chovia muito.

Durante uma das entrevistas a professora Vanessa nos disse que algumas das dúvidas que tinha com relação ao desenvolvimento e a aprendizagem do aluno Érick e de outros com deficiência era até onde o aluno poderia ter um progresso? Qual era a capacidade deles? "Até que ponto a gente deve estar insistindo?" Ela questiona será que só é mesmo no dia a dia que a gente vai saber?

Em agosto de 2002 a professora Marcela, a professora Suzi e a dirigente Tânia apresentaram um relato de experiência no $5^{\circ}$ Seminário de Educação do Município de Mauá. O nome da apresentação foi: "Inclusão: uma questão de atitude". Neste relato, contaram e mostraram um vídeo das atividades desenvolvidas com os alunos na escola. A professora Suzi também tinha um aluno com paralisia cerebral em sua turma. Durante a apresentação, a dirigente Tânia disse:

O trabalho na inclusão não é fácil, mas que elas acreditam que é possível quando se passa pela afetividade [...] ninguém está preparado para receber uma criança especial, temos a noção que não existe uma receita e procuramos fazer o melhor 
que nossa realidade permite [...] a primeira dificuldade é da aceitação [...] a aceitação está na nossa cabeça primeiro.

Em outro momento do período de coleta de dados, quando conversávamos sobre o que a escola estava aprendendo com os alunos com deficiência, Tânia falou:

\begin{abstract}
É possível conviver com indivíduos diferentes. É possível sim! Nós não estávamos acostumados. A escola não está preparada. Se a gente for parar para pensar a escola nunca vai estar preparada. Mas, quando vem e eles colocam essa criança, a gente de uma forma ou de outra vai ter que aprender a lidar com ela, com os erros, com os acertos, a gente está caminhando [...] é importante todo muito aceitar, não como aluno da Marcela ou da Suzi, mas como aluno da minha escola. A gente tem que tentar ajudar no que for preciso. O convívio vai ser diferente. É dificílimo, mas a gente aprende. A gente vê que eles são capazes de aprender. Ás vezes não no mesmo ritmo que a gente gostaria [...] acho que o lado positivo é esse de a gente ir em busca para tentar melhorar o nosso trabalho [...] até a pouco tempo a gente ficava pensando que se [o aluno com deficiência] conseguisse a socialização com o grupo já estava de bom tamanho, mas depois a gente vai vendo que não é somente isso. Então, eu acho que nos obriga a tentar alternativas para a gente estudar, melhorar a prática, a gente vai vivendo essa experiência, se não tivesse esses casos a gente estaria acomodado.
\end{abstract}

Quando, no início do período de coletas de dados, a professora Marcela leu as questões sobre suas expectativas com relação ao desenvolvimento e a aprendizagem do aluno em relação ao próximo mês, ela nos disse: "sei lá... logo que eu li isso eu pensei que eu queria que ele falasse ... queria que ele desenvolvesse a fala, que ele desenvolvesse a coordenação motora, porque eu vejo que é isso que ele quer, né! Mas a limitação dele...”. Ela disse que também estava na expectativa de que a aplicação do botox que o aluno faria em breve, melhoraria a movimentação de sua mão. Ao comentarmos sobre estas expectativas ela nos disse: "eu tento não ser tão ansiosa, mas eu percebo uma ansiedade por parte de todo mundo." Estas mesmas perguntas feitas ao grupo de profissionais da escola vieram acompanhada de um silêncio. Parecia que eles estavam pensando sobre estas questões pela primeira vez. Ana disse que apesar de não ser professora achava que essa era uma coisa difícil para pensar sobre o aluno Érick. Achou que o progresso do aluno foi ótimo, que ficava imaginando como ele estaria se tivesse ficado em casa e valorizou o fato dele estar integrado com o grupo. Na tentativa de simplificar a questão perguntamos: O que vocês acham que seria importante ele aprender aqui nestes meses que faltam para o fim do ano? Léia disse "aprender a segurar mais o giz de cera para ele poder rabiscar." Tânia acha que é importante ele continuar estimulando a fala. "Eu acho que é importante continuar fazendo esse trabalho para ver se ele consegue falar 
algumas coisas a mais". Percebemos que esta foi uma questão difícil para o grupo responder.

Para sua mãe, Regina, o que ela esperava que o Érick desenvolvesse e aprendesse na escola já tinha sido realizado. Segundo ela, a escola "ensinou a ele pedir as coisas, ele aprendeu a se comunicar do jeito dele. Ele quer a convivência com as crianças. Ele faz coisas aqui na escola que em casa ele não faz, só porque está no meio dessas crianças." Citou como exemplo ter visto ele na escola amassando massinha com sua mão, dançando, rabiscando, desenhando: "outro dia eu cheguei e ele estava amassando massinha na mão. Eu fiquei admirada [...] aí eu levei a massinha para a casa e ele não pegou de jeito nenhum [...] em casa ele não se sente tão motivado a fazer as coisas como ele faz aqui." Segundo ela, Érick não realiza estas atividades em casa. Porém, ela não esperava mais nada daquela escola porque considerava que o que ele precisava aprender daquele momento em diante seria ser alfabetizado pelo computador para se expressar melhor. E ela achava que aquela escola era limitada para isso porque não tinha recursos disponíveis e tinha um grande número de alunos o que dificultaria a professora dar a atenção que ele necessitava para tal aprendizado. Além disso, Regina tinha receios com relação à continuidade de Érick naquela escola no ano seguinte pois, percebia que a professora Marcela se interessava por ele, mas não sabia se no ano seguinte teria uma professora que também se interessaria.

$\mathrm{Na}$ última entrevista quando perguntamos a professora: Suas expectativas com relação ao desenvolvimento e a aprendizagem do aluno foram atingidas? Quais? Por quê? Marcela respondeu:

Eu acho que a participação dele aqui. Aquela coisa de estar tentando ver ele como parte integrante, mesmo com as dificuldades dele, mas que ele é capaz de fazer. Tem um limite, mas ele consegue. A minha meta desde de que ele entrou aqui no grupo foi nunca deixar ele fora de nada. Mesmo que ele não consiga, como no caso da tesoura. Ele não vai conseguir cortar. Eu sei que este objetivo vai ser dificilmente alcançado. Mas nunca deixar ele fora. Porque é assim, o princípio básico da inclusão é fazer com que a criança se sinta inclusa. Inclusa não pode ser ele no canto. Então é isso... toda a atividade que eu ia dar, eu pensava: o Érick não pode ficar de fora. Ele não pode, ele tem que fazer. Igual quando a gente está escrevendo no calendário, ele não consegue fazer, mas ele tem que saber que existe um dia após o outro, que ontem foi vinte, hoje é 21, amanhã é 22. Nem que ele não consiga registrando, mas oralmente ele tem que ter isso. Um progresso eu acho que foi a parte da comunicação. Mas você tem que estar ligada, porque ele não vai falar. Ele entrou aqui não falando água e está terminando este ano continuando não falando água. Só que eu percebo que ele quer água por causa da forma que ele demonstra. Eu ia observando, ia percebendo a seqüencia do que ele fazia, que era uma vez, era duas e que era daquele jeito... 
Questionamos a consideração que ela fez sobre ele não estar falando, já que ela tinha dado exemplo de algumas palavras que ele estava tentando pronunciar ao longo do período de coleta de dados.

É, Deigles ... é aquela coisa. Quando a mãe dele chegou aqui falando que ele falava mamãe, eu falava assim: gente, como? Só eu que não ouço? Mas, ele fala do jeito dele. Eu aprendi a ouvir, observando. Porque se eu esperasse o Érick falar água, ele ia morrer de sede estes dois anos. Porque ele não fala água do jeito que a gente. Para mim foi muito gratificante porque eu tive que observar além. Porque eu tinha que observar assim: "assi" ele demonstrou sede da outra vez deste jeito, será que é assim? E hoje eu ainda brinco com ele: se você não falar água eu não vou te dar, ai ele faz: "assi”. É a observação. Você começa a treinar isso, então você vê que ele fala, que a comunicação dele é diferente das outras crianças, mas tem uma comunicação presente sim.

Na questão: o que você acha que ele desenvolveu aqui na escola, ela respondeu que

o ponto culminante foi a sociabilidade. Isso foi mesmo ... sem dúvida. E eu acho que foi mais a ansiedade dele também. A família dele ajudou bastante, porque no começo era a coisa do medo, da insegurança (e isso passa para a criança também). Eu acho que ele ficou mais tranqüilo a partir do momento que a família dele se tornou mais segura com a escola.

E o que ele aprendeu?

É aquela coisa, você acha que ele nunca aprendeu nada. Pensando assim que ainda tem muita coisa aí pela frente. Mas a mãe dele disse que tudo que ele aprendeu (isso é palavra dela) foi aqui.

Deigles: Quando a gente fala tudo, vamos pensar em exemplos...

Só este fato dele não sentir medo do público, de estar participando de atividades com a gente... eu acho que é tudo em volta da sociabilidade mesmo.

Deigles: Estas noções que você contou que ele desenvolveu, será que ele não aprendeu aqui?

Também, mas foi com o grupo. Eu não consigo ver assim: eu cheguei e mostrei para ele, foi através de uma atividade ... Foi através da interação com o grupo, com as dinâmicas.

Deigles: Foi através das interações que ele foi aprendendo estes conceitos, estas noções?

Isso. Eu acho que foi com o grupo e eu acho que é com o diário, a participação dele e a assiduidade que ele tem na escola, porque eu não consigo ver: Oh ... o Érick aprendeu a fazer o movimento lateral porque eu dei tinta para ele ... que foi naquele momento... não foi. Foi vivenciando o dia-a-dia, o cotidiano, e a rotina do dia-adia.

Sua mãe Regina refere que na escola ele "aprendeu a pedir as coisas, aprendeu a se comunicar do jeito dele". Disse que também aprendeu a não ser mais apático. Conta que antes as crianças iam na casa dele e quebravam os seus brinquedos, mas que agora ele não deixa mais mexer. A não ser as pessoas em quem ele confia. 
Para finalizar esta breve história de Érick nas suas relações do cotidiano na sua escola, apresentamos o que a professora Marcela respondeu sobre como ela descrevia o Érick naquele momento.

Ele é uma criança ... vamos falar assim: não como as outras. Ele é uma criança que necessita sim de um grupo para estar desenvolvendo outras habilidades que sozinho ele não vai dar conta. Ele tem potencial sim, mas tem que estar ligado e oferecendo, estimulando. Tem que ter estímulo do grupo, de alguém que está coordenando o grupo. Tem que estar acreditando nele. Porque os progressos são muito lentos, mas a gente não pode desistir. Eu acho que é por aí... Tem muita coisa para vir pela frente. Por isso que tem hora que assim: ai nós não fizemos nada! Mas se a gente começar a olhar, tem sim ...

\subsubsection{Uma possível síntese da história de Érick}

Enfim ... por meio das relações com as pessoas, pudemos observar que os sons, balbucios e as palavras que Érick utilizava para comunicar-se, foram cada vez mais específicos para determinadas pessoas e situações. Através destes e de seus movimentos corporais, os profissionais da escola e seus colegas passaram a identificar o que ele estava querendo comunicar e ele conseguia manifestar seus desejos, sentimentos e pensamentos.

Com o passar do tempo, Érick procurava os colegas quando queria chamar a atenção para si, quando queria brincar, quando queria dar sua opinião, quando queria algum tipo de auxílio. E, os colegas ajudavam, conversavam e brincavam com ele sem receio e entendendo suas possibilidades de compreensão e participação. As pessoas com quem conviveu na escola aprenderam a entender as formas de comunicação de Érick e o questionavam para saber sua opinião sobre os acontecimentos e também para confirmar aquilo que ele estava querendo manifestar à outra pessoa. Quando, mesmo assim não o compreendiam, perguntavam para outra pessoa o que ele estava querendo dizer.

O contato esporádico com pessoas que não faziam parte de seu convívio diário ficou mais freqüente para o aluno, o que o acostumou a se relacionar com estas pessoas. Assim, só ficava tímido nos primeiros momentos em que conhecia uma nova pessoa, depois ficava descontraído na presença dela.

Érick também se acostumou em estar no meio de várias pessoas, como um grupo grande de crianças ou com a platéia que o assistia na apresentação de fim de ano. 
Os profissionais da escola perceberam que era necessário que ele ficasse na escola no dia que sua professora de referência precisava faltar. Assim, Érick passou a não mais se incomodar de ficar com qualquer outra professora.

A relação de Érick consigo mesmo progrediu na medida em que ele foi incentivado a participar das atividades da forma como lhe era possível utilizando seu corpo e, foi proporcionado a ele que experimentasse várias posições e lugares para estar. Ele movimentava mais o seu corpo para tocar e tentar pegar determinados objetos e pessoas.

A possibilidade de circular pelos diversos espaços da escola permitiu que Érick aprendesse a saber e comunicar aos outros onde era cada ambiente da escola. Também aprendeu em que lugar se guardava os materiais de uso pessoal e coletivo do cotidiano. Érick foi incentivado a brincar na areia e nos brinquedos do parque, fatos que colaboraram para ele experimentar movimentar-se no espaço de maneiras diversificadas recebendo vários estímulos sensoriais. Ir ao parque passou a ser uma de suas atividades prediletas.

Érick se locomovia pelos espaços da escola na maioria das vezes em seu carrinho. A professora Marcela o conduzia principalmente nos lugares acidentados, mas ela dividia esta tarefa com os colegas do aluno e demais profissionais.

Ele, como os demais alunos, rodiziavam o lugar em que sentavam na sala de aula. A professora Marcela considerava importante todos estarem se relacionando com colegas diferentes. Porém, ela sempre tomava o cuidado de não deixá-lo de costas para a porta e para a professora para ele poder ver o que estava acontecendo.

Érick realizava as atividades no tempo o qual a professora planejava para tal, considerando suas características. Conforme realizava diariamente determinadas atividades, como a de se alimentar, foi diminuindo o tempo necessário para realizála.

O hábito de cantarem músicas e realizarem brincadeiras de seqüência numérica e rítmica, contribuiu para ele aprender a acompanhar o ritmo das brincadeiras e a contar. Igualmente, o hábito de realizarem a roda de conversa contribuiu para que ele aprendesse a mostrar o cartão correspondente da seqüência da rotina do dia. Esta passou a ser conhecida pelo aluno que se manifestava para participar de acordo com o que era realizado. 
Era oferecida ao Érick, a possibilidade dele tocar e manipular, da forma como lhe era possível, vários dos objetos do cotidiano escolar, mesmo quando ele não tinha movimentos adequados para utilizá-lo, como no caso da tesoura. Esta atitude contribuiu para que ele aprendesse a conhecer a função dos objetos e demonstrar a intenção de realizar movimentos para utilizá-los de acordo com sua função.

Érick, sua professora e seus colegas procuravam uma forma melhor de posicionar os objetos que manuseava para facilitar sua utilização. Quando necessário, eles o auxiliavam segurando partes do seu corpo para que o movimento necessário fosse realizado ou segurando alguns objetos para que ele pudesse realizar parte da atividade ou os fixando ou ainda, aumentando o tamanho ou mudando a forma dos objetos.

Com o contato freqüente com tinta, cola e areia, ele passou a não ter mais ânsia desses materiais porque sabia que após o seu uso lavaria as mãos. Passou também, a não se incomodar tanto quando outras crianças utilizavam materiais ou brinquedos seus. A intervenção dos profissionais colaborou para que ele, mesmo com ciúmes, compreendesse a necessidade de emprestar e compartilhar os objetos do cotidiano escolar, sendo que todos deveriam tomar cuidado com os pertences dos outros.

Érick teve contato com vários brinquedos, jogos e objetos. Isto colaborou para que ele aprendesse a compreender as regras e algumas formas de brincar. As brincadeiras de faz-de-conta foram algumas das atividades em que ele teve um envolvimento grande, prazer em realizá-las e demonstram o progresso do desenvolvimento cognitivo do aluno.

A brincadeira do pimpão, que era realizada habitualmente na escola, proporcionou com que ele tivesse que manter a atenção, compreender a seqüência numérica e dos movimentos necessários que deveriam ser realizados quando chegasse sua vez. Além disso, estimulava-o a realizar movimentos faciais e esboçar sons para pronunciar o número correspondente da seqüência.

Ao participar das atividades de pintura com giz-de-cera, tinta, cola, etc, Érick teve a possibilidade de compreender algumas noções de quantidade, de cores, e de espaço. Com o passar do tempo, tinha a nítida intenção de pintar no espaço determinado. 
Participando da merenda, ele experimentou vários alimentos que permitiu-o saber quando eles eram doces, salgados, azedos e a reconhecer quando os alimentos estavam quentes ou gelados. Recusava-se a comer o alimento quando, pelo seu aspecto, percebia que não gostava.

Como todos os alunos, tinha dia que ele era ajudante da professora na distribuição dos materiais aos alunos. Um colega auxiliava-o empurrando o seu carrinho.

Érick na vivência cotidiana na escola teve a oportunidade de compreender regras do convívio social da escola, regras das atividades e de suas seqüências, realizar associações entre figuras, pessoas e situações que já viveu ou viu em algum lugar.

No seu cotidiano escolar, Érick estabeleceu relações com pessoas, com espaço, com tempo, com objetos, com atividades de forma indissociável e interdependente. Estas relações contribuíram para o seu desenvolvimento e para a sua aprendizagem porque respeitaram e valorizaram suas possibilidades de participação, porque colocaram em funcionamento seus aspectos afetivos, sensoriais, motores e cognitivos, porque ele foi considerado em sua singularidade ... porque ele viveu um cotidiano escolar que acreditou que ele podia aprender!

\section{2. Ítalo Júlio e suas relações no cotidiano escolar}

Ítalo Júlio antes de entrar na escola de educação infantil do município de Mauá em 2002, havia estudado dois anos em uma escola particular perto da casa em que ele e sua família moravam no município de São Paulo. Segundo Neuza, sua mãe, na turma em que ele estudava tinha "pouquinhas crianças, seis na sala dele [...] lá ele só ficava de lado, olhando as outras crianças brincar, não participava mesmo das brincadeiras com as outras crianças." Neuza contou que sua família não achava uma boa idéia colocá-lo na escola regular. A instituição filantrópica onde o aluno realizava acompanhamentos terapêuticos em São Paulo foi quem incentivou a mãe para que ele freqüentasse esta modalidade de educação. Logo que a família mudou para Mauá, matricularam Ítalo Júlio na escola em que realizamos a pesquisa. Neuza também tinha um pouco de receio dele estar nesta escola, principalmente porque a escola era cheia de escadas e segundo ela, a coordenação motora e o equilíbrio do 
aluno não eram muito bons. Tinha medo que os outros alunos o derrubassem a qualquer momento. Um dos fatores que contribuiu para que ela se sentisse mais segura foi o fato de que no dia em que ela fez a matrícula, ter conversado com a diretora que "parecia assim tão interessada que peguei confiança".

Yara foi a professora da sala onde o aluno estudou. No primeiro encontro que realizamos, Yara disse que no início ficou assustada pois nunca teve um aluno especial e naquele ano tinha quatro: "uma criança com síndrome de Down [Ítalo Júlio], uma com 'peito para dentro' - problema torácico, uma que anda com a perna arrastando e tem dificuldade no uso das mãos e outra que tem muita dificuldade visual." Marisa, a dirigente da escola, falou que essa situação aconteceu porque os pais dos outros alunos quando fizeram a matrícula não comunicaram que seus filhos tinham alguma deficiência. Só quando os alunos começaram a freqüentar que a professora e a dirigente perceberam. Elas optaram por não fazer a transferência de sala de alguns alunos porque consideraram que não seria bom para eles já que haviam iniciado a constituição do grupo. Além disso, a professora Yara considerou que seria possível aceitar o desafio de realizar o trabalho com os alunos desde que tivesse apoio de todos na escola. Marisa se comprometeu a não matricular mais nenhum novo aluno na sala caso houvesse alguma desistência de aluno e a providenciar uma pessoa para acompanhar a professora em atividades no parque.

No segundo encontro com a pesquisadora, Yara entregou por escrito como descrevia o aluno Ítalo Júlio naquele momento:

É uma criança amorosa, não atende pelo nome Ítalo, nem sabe que o nome dele é este. O chamam de Júlio que é seu sobrenome, sabe sua idade 5 anos e conhece algumas cores.

O seu relacionamento com os colegas da classe e da escola é bom, mas poderia ser melhor, pois muita coisa que ele fala as crianças e nem a professora entendem.

Não fala frases e sim palavras soltas exemplo: Eu quero fazer xixi, fala apenas “xixi”, isto quando pede na maioria das vezes precisa fazer Júlio vai fazer xixi, eu programei o horário entre 9:30 às 10:00, pois fazia todo dia xixi na calça. Ele mais gesticula do que fala.

Adora música principalmente os gestos ou passinhos que são feitos com a música, fica muito atento e faz com alegria e espontaneidade.

Tem ainda dificuldade motora principalmente em servir-se na merenda, levar até a mesa para comer. Apesar da dificuldade de coordenação já consegue subir e descer escadas sozinho.

Quando estimulado em jogos, brincadeiras e dança demonstra maior interesse e participação.

Costuma dar atenção somente as pessoas que conhece, quando alguém diferente o chama ou fala com ele costuma fechar-se, abaixar a cabeça e fica estático. ${ }^{47}$

${ }^{47}$ Yara não fez esta descrição baseada no roteiro de observação utilizado na pesquisa. 
Nesse encontro discutimos a questão em que ela respondeu o que esperava que Ítalo Júlio desenvolvesse e aprendesse no próximo mês. Conversamos sobre as razões pelas quais ela esperava alcançar aqueles objetivos com o aluno e levantamos possibilidades de intervenção na medida em que eles fossem pertinentes, considerando as necessidades do aluno. Sua resposta foi a seguinte:

Ir ao banheiro sozinho; subir e descer escadas sem auxílio da professora ou colegas (já estou conseguindo); consiga expressar mais através da fala pois usa muitos gestos para desenvolver suas ações; aprenda a limpar o nariz; no escorregador consiga escorregar sentado, não deitado como vem fazendo.

Embora o período de referência da questão tenha sido de um mês, percebemos nos registros e nas entrevistas realizadas, que estes objetivos no trabalho com o aluno estiveram presentes em outros momentos.

Para a professora Yara e demais profissionais que tinham contato com Ítalo Júlio na escola, "a ansiedade que dava no começo [do trabalho com o aluno], era para ele falar, porque ele ainda não fala o que quer" (Alessandra). Elas percebiam que "ele tem necessidade de se comunicar. Ele vem e já te abraça, ele faz muito esforço. Você percebe a ansiedade dele querer falar." (Regiane). Segundo a professora Yara, "antes não dava para entender o que ele falava, nem eu conseguia definir o que ele falava."

Ítalo Júlio se utilizava mais de gestos do que da fala para se comunicar. As crianças e a professora tinham dificuldades de entender o que ele falava. Com o passar do tempo ele começou a pronunciar algumas palavras, como xixi, o nome da professora, de alguns colegas, de outros profissionais da escola, da mãe, da irmã, de alguns brinquedos, entre outras. Embora não tenha chegado a falar frases e pronunciar as palavras nitidamente, dava para compreender o que o aluno queria dizer pelo contexto e também pelos gestos que utilizava. Ítalo Júlio foi ficando mais comunicativo e participativo nas atividades da escola. Regiane nos disse que seus colegas passaram a entender o que ele queria dizer "mesmo se for por gestos, agora eles entendem". Eles não precisavam perguntar mais para a professora o que ele queria dizer. No início, na roda de conversa ele só ficava observando as pessoas. Depois, quando questionado, dizia o nome de seu pai, sua mãe e irmã.

$\mathrm{Na}$ maior parte das vezes ao longo do ano, Ítalo Júlio necessitava ser questionado para responder por meio da fala. Quando Yara perguntava se ele queria ir ao banheiro, ele respondia "qué" ou "xixi". Em outras situações respondia "sim" 
ou "não". Para se expressar e demonstrar se queria ou não alguma coisa, às vezes dava beijos e abraços nas pessoas; às vezes fazia gestos e ia atrás do que queria; às vezes chegava perto do que queria, olhava ou apontava e se perguntavam se era determinada coisa que ele queria, ele confirmava com simples palavras; às vezes, quando precisava de ajuda do outro, olhava para a pessoa e falava: "qué"; outras vezes dizia não ou gritava quando um colega fazia algo que não gostava. Para pedir ajuda de sua professora para descer do escorregador, a chamava pelo nome. Quando queria o fantoche "Lolo", brinquedo que ele gostava muito e brincava sempre com a professora Alessandra, a puxava pela mão e falava: "Lolo". Pedia para brincar de esconde-esconde chegando até os outros e tapando os olhos com a mão. Avisava a sua mãe quando sua professora Yara estava chegando. Passou a responder aos outros quando solicitavam sua opinião e agradecer quando o outro lhe fazia um favor. Dizia: "obrigado!" (Yara).

Ítalo Júlio adorava ser valorizado quando fazia alguma coisa certa e quando chegava ao término de uma atividade. Quando os colegas batiam palmas nestas situações, ele também batia e vibrava. Ele também tinha esta atitude quando alguém fazia alguma coisa que ele queria. Ele fazia "graçinhas" para chamar a atenção dos outros. Segundo a professora Alessandra, "ele entra direto [na sala de aula dela] $e$ já vai mexendo com as crianças e comigo, isso é diário, e ele entende se eu peço para ele fazer alguma coisa". Quando ele não queria fazer o que o outro pedia, ele falava "não", mas ele normalmente "não mostra resistência ao é que pedido." Quando ficava professora diferente na sala, às vezes, ele subia em cima da mesa, entrava dentro do armário, mexia em pulseira, brinco, anel, para chamar a atenção.

No início do ano só se reconhecia pelo nome Júlio. Não sabia que seu nome também era Ítalo. Não prestava atenção e não respondia na hora da chamada. Depois começou a respondê-la, inclusive quando chamado o nome Ítalo. Sua professora Yara contou que trabalhou bastante para ele se reconhecer pelo seu nome todo e que "na chamada ele fala: presente". Yara considerou que o aluno passou a ficar mais atento ao que o outro falava ao longo do ano. Ele entendia o que lhe era questionado, assim como regras e comunicados quando lhe era explicado algumas vezes. Demonstrava este entendimento falando sim ou não, balançando a cabeça. Sabia bem 
o que era certo ou errado. Não mexia no que não podia depois de ser orientado algumas vezes.

Ítalo Júlio era bastante tímido e retraído. Quando as pessoas com quem não estava acostumado a conviver falavam com ele, ele se retraia, abaixava-se e não falava. No dia em que a pesquisadora foi conhecê-lo, ele apenas ficou observando o que ela lhe dizia, e não fez nenhum gesto e nem pronunciou nenhuma palavra. Yara disse que ele dava atenção só para quem conhecia. Não procurava os colegas de forma espontânea. Para ele brincar com os colegas, precisava-se incentivar e perguntar se ele queria brincar. Na entrevista final, a professora Yara nos disse que "ele está mais espontâneo" que buscava o contato com os outros colegas "principalmente em jogos, brincadeiras e dança". Ele se aproximava dos colegas para poder participar. Às vezes ia para o meio dos alunos e sentava próximo a eles. "Muitas vezes, quando estou no parque e as crianças estão numa brincadeira sentadas no círculo, ele já senta no círculo sem saber o que é, já quer participar." (Alessandra). Professora Regiane contou que ele adorava o seu aluno Caio. No intervalo sempre procurava o aluno e o puxava para dançar. Segundo ela, "ele adora dançar com ele".

Ítalo Júlio passou a falar algumas palavras com pessoas que não faziam parte de seu convívio diário. Apesar disto, não falava muito com pessoas desconhecidas, ficava só as observando. Com as pessoas que conhecia ele conversava. Profissionais da escola percebiam que ele diferenciava as pessoas conhecidas das desconhecidas. Ele passou a conhecer profissionais da escola que via com freqüência e chamava alguns pelo nome. Beijava, abraçava e falava com eles quando solicitado. "Comigo ele conhece bem, inclusive o carro. Ele sabe quando eu estou e quando eu não estou. Ele conhece o carro, e quando eu desço aí na rua ele fala para a mãe que eu estou chegando." (Marlene). Só não sabia distinguir os profissionais pela função que exercia. A não ser a diretora, que ele reconhecia pela sua função e não pelo seu nome. "Ele ficava chamando a diretora. Do jeito que ele falava dava para ver que ele estava chamando a diretora, até eu achei engraçado o dia que eu vi ele lá chamando a diretora, a Marisa, porque ele estava acostumado com ela." (Cintia).

Cintia foi a diretora da escola a partir de agosto daquele ano. A prefeitura do município passou por uma reforma administrativa e a Marisa foi assumir a sua 
função de supervisão técnica na Secretaria Municipal de Educação, Cultura, Esportes - SMECE. A escolha da nova dirigente foi realizada por entrega de projetos, avaliação e seleção via comunidade escolar e SMECE. A respeito desta mudança, Neuza, mãe de Ítalo Júlio, disse: "pelo projeto dela [Cintia] tava assim: inclusão. Não colocou inclusão com deficiência. A inclusão dela é todos os níveis na escola: pobre, rico, branco. Pela inclusão como ela falou, o projeto dela era esse. Então já me preосирои." Percebemos que o fato de a dirigente não ter mencionado explicitamente as pessoas com deficiência como também pessoas incluídas na escola, trouxe temporariamente uma certa insegurança para a mãe. Discutimos este conceito de inclusão com a Neuza para que ela se tranqüilizasse e confiasse na proposta da nova dirigente.

Caio, a professora Yara, a professora Alessandra, a professora Regiane, a escriturária Marlene e seus colegas de classe eram referência na escola para Ítalo Júlio durante as atividades da rotina. Conhecia a todos pelo nome e pronunciava do seu jeito. Yara contou que o nome do primeiro colega que ele pronunciou foi Diogo. “[...] eu lembro que o primeiro nome que ele falou foi o do Diogo. Nossa, ele [o Diogo] ficou tão contente! Ai ele veio e falou: professora ele falou meu nome. A criança que está do lado dele fica contente com o progresso que ele teve."

Se Ítalo Júlio precisava de alguma ajuda, procurava algum aluno que conhecia. Também se aproximava dos alunos em outras situações: "O Caio levou uma bronca e ele foi lá fazer carinho nele [...] ele foi lá consolar o amiguinho [...] ele é muito carinhoso." (Regiane). Sobre esta situação, a professora Alessandra completou: "ele puxava ele para levantar, fazia carinho".

Para Yara, o relacionamento do aluno com seus colegas sempre foi bom, mas melhorou quando os colegas passaram a compreender a forma dele ser e se comunicar.

Segundo a professora Regiane, "têm alguns [colegas] que até fazem do Júnior um bebezinho, um cristalzinho, querem ficar com ele no colo, fazem dele um neném". Ela achava que ele gostava de ser tratado desta forma. Quando isso acontecia, Regiane disse que "a gente está sempre orientando a não fazer isso ... é lógico que tem que ter um carinho sim, mas não é uma forma de estar fazendo ele ficar dependente, é tirando essa dependência dele." Ao comentarem estas atitudes 
das crianças e como eles intervinham frente a estas situações, discutimos as consequiências de se perpetuar a idéia da pessoa com deficiência como sendo um "eterno bebê" e o quanto isso podia prejudicar o desenvolvimento da autonomia do aluno.

Como nós mesmos pudemos observar na ocasião da festa junina de sua escola no mês de junho, Ítalo Júlio parecia gostar de ficar no colo das pessoas. Depois que dançou, ficou um tempo no colo de sua tia e, posteriormente, no colo de sua irmã. Neuza, sua mãe, contou que ele gostava muito desta sua tia, irmã dela: "ele ama ela". Como sua tia morava no fundo da casa de Ítalo Júlio, era freqüente ele estar na casa dela ou vice-versa. Quando ele estava lá e sua mãe o chamava par ir embora, era “um sacrifício, uma choradeira [...] também, fazem tudo o que ele quer: dão comidinha na boca, só fica no colo, ficam tratando ele como se fosse um bebê".

Quando começou na escola, Ítalo Júlio não comia a merenda. Colocava a mão e a cabeça dentro do seu prato. Professora Yara achava que esta era uma atitude para chamar a atenção dos outros, pois gostava de ter a atenção de todos. Não tinha muito equilíbrio e coordenação motora para levar o prato de mingau até a mesa ou segurar a caneca com leite. Profissionais achavam que ele não tinha muito estímulo em casa para fazer estas atividades. Sua mãe disse que incentivava sim que ele as fizesse, só não o deixava servir-se sozinho. Conta que sua filha mais velha só foi realizar esta atividade após os nove anos de idade. Na escola, a professora trabalhou bastante com ele a atividade de se servir sozinho. Ela colocava uma quantidade menor de leite na jarra para facilitar que ele conseguisse por na sua caneca. Até antes do recesso ele estava comendo sem por o rosto e a mão dentro do prato e se servindo sozinho. Comia mingau, canjica e arroz doce. Quando queria mais - o que era raro, pois demorava muito tempo para comer, e quando acabava, já era hora de voltar para a sala - ia ao balcão da merenda e ficava parado olhando até que alguém percebesse que ele estava lá e perguntavam se queria mais comida. Depois do recesso professora Yara achou que "ele deu uma regredida em algumas coisas" como na alimentação. "Na merenda, que nem tipo mingau, canjica, arroz doce, ele coloca num prato mas ele não come. Ele fica esperando que alguém coloque na boca [...] se coloca na boca dele ai ele fica delirando, ele adora! Aí começou a bater palminha, dar risada." Yara acha que em casa a comida era dada na boca dele. Na hora de 
comer fruta "ele pega, mas não come. Por quê?? Porque em casa era picada. Então perguntei para a mãe: ele não come fruta, tipo mamão, maçã? Ela falou que come, mais em casa é picada". Na escola eles tinham o costume de dar a fruta na metade para os alunos. As frutas que ele gostava e reconhecia eram banana e maçã. Do resto ele não comia e chamava tudo de maçã.

Yara percebeu essa regressão em outras atividades da escola. Ela acha que o que contribuiu para isso foi "muito tempo afastado da escola". Depois do recesso no meio do ano, ele estava começando a voltar a fazer sozinho algumas atividades, mas, depois de outubro, após ficarem uma semana sem aula por causa do Seminário de Educação do Município, ele deixou novamente de fazer algumas atividades que já havia aprendido a fazer sozinho. Estas atividades foram principalmente as de alimentação, higiene e locomoção. Outro fato que aconteceu no início do mês de outubro foi a implementação do projeto de salas ambientes. Toda organização do espaço da escola foi alterada assim como a dos materiais.

$\mathrm{Na}$ merenda Ítalo Júlio gostava muito de passar manteiga ou geleia no pão ou bolacha. Professora Yara achou que sua coordenação motora nesta atividade melhorou com o passar do tempo, embora continuasse com dificuldade nesta atividade. Ela achava que ele não tinha muita oportunidade de realizá-la em casa. Marlene contou que

\begin{abstract}
Uma coisa que eu achei interessante é que outro dia eu cheguei na merenda e eles estavam passando manteiga no pão e ele estava com a faca passando. O coleguinha já queria passar a manteiga para ele e pediu a faca para ele e ele disse: "não"! Ele queria passar bastante. Enquanto ele não pôs o suficiente, o que ele queria, ele não entregou a faca para o colega. Ele já sabe a quantidade que ele quer. E o outro se intimidou com o não dele!
\end{abstract}

No começo do ano, Ítalo Júlio não limpava o seu nariz sozinho. A professora começou incentivá-lo a realizar esta atividade sozinho. Dava o papel na mão dele para ele limpar. Se o papel não chegava a tempo, ele esfregava com a mão a secreção no rosto inteiro ou passava o dedo e punha na boca. Discutimos com a professora a importância dele ter a percepção de que o seu nariz estava sujo e sentir a necessidade de limpá-lo sem que necessitasse ser avisado. Pensamos algumas estratégias para favorecer esta percepção como: antes de dar o papel na mão dele, perguntar para ele e para o grupo de alunos que estava com ele, se tinha alguém com o nariz sujo, ou então, levá-lo ao espelho ou pedir para ele ir se olhar quando o nariz estivesse sujo. 
Yara contou que o que havia conseguido era que ele fosse buscar o papel higiênico quando ela ou os alunos davam pistas sobre o local em que ele se encontrava. As crianças diziam com a orientação da professora: “Júlio olha o papel! Está lá, tem que limpar!" Depois de limpar o nariz ele já jogava o papel no lixo.

Era comum, no início do ano, Ítalo Júlio fazer xixi nas calças, pois não avisava quando queria ir ao banheiro. A professora Yara começou a programar um horário para perguntar se ele estava com vontade de ir e acompanhá-lo. Ele fazia xixi sentado e necessitava de ajuda para abaixar e levantar suas calças pois não tinha coordenação e força para fazê-lo sozinho. Depois de um tempo de trabalho, o aluno passou a ir acompanhado de um colega de classe. Não aceitava mais a companhia da professora. Depois começou a ir sozinho, mas ainda precisava ser questionado se queria ir. Chegou algumas vezes a ir ao banheiro sozinho sem pedir para a professora e sem ter que ser questionado. Apesar da dificuldade, estava abaixando e subindo as calças, dando descarga - antes não conseguia porque não tinha força - e lavando suas mãos. Sofia, auxiliar de apoio operacional, encontrava algumas vezes o aluno no banheiro.

A gente sabia que ele tinha problema, aí eu via ele indo lá no banheiro e ai comecei a observar. Ele tá lá no banheiro, ele tem que se virar sozinho, a gente ajuda assim, sabe? E ele gosta. [...] ele tenta fazer xixi sozinho, lavar as mãozinhas. Outro dia eu arrumei a blusinha dele que estava molhando [...] a gente faz porque acaba ficando com dó de não ajudar, mas eu não sei se ele entende alguma coisa [...] a gente ajuda, mas não que esteja precisando realmente da ajuda. Eu já vi ele lavando a mão sozinho do jeitinho dele.

Depois do recesso e do mês de outubro, Ítalo estava indo no banheiro só quando alguém o levava até a porta do banheiro, depois ele ia sozinho. Quando perguntamos à professora Yara o porque dele não ir ao banheiro ela nos respondeu: "não sei, ele fica apertado mas não vai. Ai se falamos: 'Júlio você quer ir no banheiro?' Ele diz: ‘qué' [...]. Você sabe que ele quer ir no banheiro, mas ele não vai se não tem alguém que o leve até pelo menos a porta do banheiro, ele não vai". Em outro dia da entrevista sobre este mesmo fato, Yara nos disse: "ele sabe que tem que ir, mas ele não vai enquanto ninguém fica perguntando. Que nem, eu estou sempre perguntando. Se vai uma outra professora, assim por exemplo, se eu faltar e for uma outra professora, talvez ele faça." Yara comentou que ele estava apegado com o seu colega de classe Yves e este o estava acompanhando até a porta do banheiro.

Ítalo Júlio escovava os dentes sozinho. A professora Yara não sabia se ele sabia tirar a tampa e colocar a pasta de dente na escova porque era sempre um coleguinha 
que fazia isso para ele. Sugerimos que ela experimentasse deixá-lo realizar estas atividades sozinho, uma vez que ela nos disse que achava que ele tinha a possibilidade de desenvolver esta habilidade,

[...] eu acho que sim porque ele pega a canequinha dele, a toalhinha de dentro da mochila. Ele já está fazendo isso. Ele já pega e já guarda. Quando é hora de escovar os dentes ele vai lá, ele mesmo pega. Então ele não está tendo tanto ajuda. Não há necessidade mais, como antigamente.

Até o fim do período de coleta de dados ele não tinha experimentado realizar estas etapas. Ele ia ao banheiro mas não levava a toalha e a caneca junto porque como gostava de mexer com água, molhava o corpo todo e não percebia. Sobre a utilização destes utensílios, Yara disse na última entrevista que: "eu não costumo dar para ele não. Só dou a escova, aí a toalha ele enxuga a mão na hora que volta. Ai ele mesmo pega na mochila, ai ele enxuga a mão.” Entretanto, Yara percebeu que "se você conversar bastante com ele, ele chega não molhar. Se fala: não tem outra, só tem essa, então não pode molhar ... se vai falando, acho que ele vai fixando, aí não se molha".

Yara em um de seus registros relatou que Ítalo Júlio já conhece as partes do seu corpo em brincadeiras e músicas. Sabe localizar cada
parte com facilidade. Utiliza das partes do corpo para brincar, comer, andar,
pintar, gestos (movimentos), escovar os dentes, fazer xixi, abaixar e levantar as
calças, lavar as mãos, limpar a mesa, colocar no lugar prato e copo utilizado na
merenda.

Durante uma de nossas entrevistas disse que ele estava tirando e pondo a sua blusa, necessitava um pouco de ajuda apenas quando a blusa não passava pela cabeça. Ela, assim como outros profissionais da escola percebiam que ele já estava mais independente. Percebiam que ele fazia algumas atividades sem necessitar e até mesmo recusava a receber ajuda dos colegas, como para dar a mão para descer as escadas do andar superior para o andar térreo da escola. Consideravam que a coordenação motora do aluno melhorou durante o trabalho realizado. Yara contou que quando chegou na escola, Ítalo Júlio só andava em lugares retos e quase não corria. Não jogava bola e nem corria atrás dela. Depois “ele ainda não se sente muito seguro de estar lá correndo, agora se você pedir para ele correr, ele já dá umas corridinhas. Ele dá umas desequilibradas. Você vê que ele ainda não tem muita firmeza de estar jogando futebol lá no meio com os outros." Com o passar do tempo 
ele foi gostando mais de bola e estava "começando a jogar futebol igual aos outros." Quando chutava com muita força, caía. "Ele fica nervoso quando a bola não vem no pé dele. Ele corre para um lado e a hora que as crianças estão virando para o outro lado, ele ainda está indo." (Alessandra).

A melhora na coordenação motora também pôde ser observada nos gestos e passos que realizava para acompanhar a música. No início dos ensaios para a festa junina não conseguia coordenar dois movimentos. Por exemplo: fazer os movimentos do braço com os passos da perna. Com o passar dos ensaios Yara percebeu, o que também pudemos observar na apresentação da festa junina, que ele, por vezes, conseguia coordenar os dois movimentos e estava muito atento à seqüência da dança. Ficava observando os colegas que eram sua referência para a mudar os passos. A coreografia que eles estavam ensaiando era de música de cowboy. Teve um dia que "a mãe dele esqueceu de mandar o boné, porque a gente está ensaiando com chapéu. E o boné é a referência dele. Sem o boné ele não consegue fazer. Aí eu tive que pegar um boné emprestado do coleguinha para ele fazer. Ele ficou sem uma referência." (Yara).

Durante os ensaios para a festa junina, Yara o colocava para dançar cada dia com um aluno diferente, para "ver uma criança mais ágil para ir com ele no dia [...] que tem mais paciência [...] que se coordena melhor para estar auxiliando ele". Os outros alunos não trocavam de parceiro. Ela também achou importante fazer este rodízio para que as mães dos outros alunos não fossem falar depois: "Ah, fulano atrapalhou na dança". As escolhas dos parceiros eram feitas pelos próprios alunos. Yara às vezes deixava Ítalo Júlio escolher seu par, mas não deixava os outros o escolherem porque "se pedir para escolher, todo mundo quer ir. Acho que nesse sentido de estar ajudando, não tem isso de não ir com ele. Eles vão. Para eles é normal, não tem essa diferença."

Ítalo Júlio sempre chegou à escola e foi embora no colo da mãe ou da pessoa que o trazia. Yara disse que conversou muito com a mãe sobre a importância de deixar ele andar sozinho, mas não adiantou "saiu do portão da escola a mãe leva no colo." Segundo Neuza, "ele não quer saber, faz de tudo para não andar. Fala que o pé tá doendo que o dedo tá doendo." Ela já foi no ortopedista, fez vários exames e não deu nenhuma alteração que justificasse ele dizer que o pé e o dedo doem e ela também 
"já olhei a unha dele, para ver se era a unha, mas não é." Segundo os profissionais da escola Neuza era muito insegura. Ela "morre de medo dele cair da escada" (Yara); "eu vejo a mãe querer proteger para ele não cair" (Marlene). No começo do ano Ítalo subia as escadas de mão dada com a professora. Depois ela começou a deixá-lo ir apoiando no corrimão com uma mão e dando a outra mão para um coleguinha. Neuza perguntava para Yara, "mas e se ele cair" e ela respondia: "eu estou observando". Cada dia era um colega diferente que o ajudava a subir as escadas, "o que tem problema de visão ajudou ele a subir". No fim do ano o aluno não estava mais precisando de auxílio de um colega para subir as escadas. Só precisava segurar no corrimão. Yara disse que "de vez enquando alguém da outra sala vê ele subir - os coleguinhas de outra sala - eles seguram por segurar. Agora os meus eles já sabem que não precisa [dar a mão para ajudá-lo a subir as escadas], não há necessidade." Segundo Marlene, "até mesmo para subir a escada a gente vê que ele sobe com mais segurança do que no início das aulas [...] ele já se sente seguro." Mesmo assim, era freqüente a mãe ficar observando de longe até a subida do aluno pelas escadas. Sobre este fato, Neuza disse:

Eu ficava com o coração! Aí eu falei, mas elas ficavam ali com as professoras conversando e ele subindo. Ai ela [Yara] falou: "se você que é mãe não confiar, o que a gente vai fazer?" Eu falei: "mas e se uma criança dessa derruba meu filho de lá de cima?" E ela disse: "não, porque todas as crianças já conhecem o Júlio e não sobem e descem as escadas correndo." [...] Mas eu fico esperando até ele entrar na sala. Quanto tá com elas não, porque a responsabilidade é toda delas. Mas, quando entrego para ir com amiguinho, eu fico olhando até o final.

Yara observava que para Ítalo Júlio descer as escadas era mais fácil do que subir. Às vezes, quando alguma criança queria dar a mão para ajudá-lo a descer as escadas, ele falava "não", demonstrando que não precisava de auxílio.

Em alguns momentos na escola, Ítalo Júlio ainda aceitava que alguns colegas ou outros profissionais que lhe eram familiares, o ajudassem a se locomover, como o momento de chegada na escola e em algumas partes com piso em desnível. Ele aceitava que algum colega desse a mão para ele ir até o início da escada. Isto acabou se tornando uma rotina para o aluno na entrada. Sobre esta situação da entrada do aluno na escola, Alessandra contou uma situação interessante que reflete aspectos da compreensão de Ítalo da noção de se perceber enquanto pertencente a um grupo:

Outro dia, acho que demorou para ele entrar [na escola] porque quase todas as crianças já tinham ido para a sala, então eu perguntei no portão: "quem estuda na sala do Júlio?" E ele mesmo levantou a mão e disse: "eu”. Eu achei uma graça isso 
daí, porque a rotina dele já está tão assim, a entrada ele já sabe que alguém tem que dar a mão, então ele mesmo falou: "eu".

Marlene contou que ela já não pegava mais na mão dele na porta da escola para levá-lo à escada, ela apenas o acompanhava: "eu venho conversando com ele".

Quando chegou na escola, Ítalo Júlio não sentava-se na cadeira sozinho nem tirava sua mochila das costas. Necessitava de ajudava dos colegas. No fim do ano ele já fazia não mais necessitava de auxílio nestas atividades.

Do início do ano até outubro, época em que aconteceu a mudança do espaço físico e dos materiais da escola em decorrência do projeto de sala ambientes, Ítalo Júlio já sabia "localizar-se na escola. Sabe onde fica a sala onde estuda, o banheiro [do andar de cima], refeitório, parque, sala da diretora e dirigisse a esses locais até sozinho ou obedecendo a ordens ou pedidos." (Yara). Ele estava aprendendo onde era o banheiro do andar debaixo e também sabia onde era a sala da professora Alessandra. Yara às vezes pedia para ele ir entregar ou buscar alguma coisa na sala da professora Regiane. Ele ia, mas Yara o orientava com pistas da porta da sua sala. Depois da mudança para salas ambientes ele e alguns de seus colegas estavam sem referência das salas de aula. Quando chegava na escola eles não sabiam mais para qual sala deveriam se dirigir.

Yara contou que Ítalo Júlio sabia onde era o lugar de guardar os objetos de uso mais freqüente na escola "sabe onde guarda jogos e materiais escolares." Sabia que o fantoche "Lolo" ficava guardado na sala da diretora. Ele sabia que

"as coisas da bolsa dele têm que tirar e colocar, sabe que tem que guardar os jogos
na caixa, o jogo de montar tem que colocar dentro do pote e que se ele rabiscou
alguma coisa ele vai ter que limpar. Ele parou de rabiscar a mesa, de tanto ter que
limpar. Ai ele pega e limpa. Ele viu que a dificuldade é grande de estar ali
esfregando só para tirar a sujeira que ele fez."

Ítalo Júlio sabia onde era o lugar em que tinha prato, caneca, garfo, onde tinha que jogar o lixo, porém tinha que ser incentivado para pegar e guardar estes utensílios. Yara achou que ele estava preguiçoso depois das férias. Ela também achava que "na escola ele tem mais estímulos do que ele tem em casa [...] falta um pouquinho da mãe estar estimulando".

Segundo Yara, ele gostava "muito de tirar o sapato, de ficar sem sapato [...] depois não quer colocar, é a maior dificuldade [...] não sei se é porque é ortopédico". 
Ítalo Júlio "identifica e sabe a utilidade de cada objeto ou material. Lápis e giz de cera para escrever na folha, massinha para brincar, joguinhos para montar, brinquedo para brincar com os colegas, colher para comer [...] vassoura para varrer". (Yara). Ele aprendeu a abrir e fechar as caixas de brinquedo e ajudar a professora a guardar e organizar os materiais.

Ele reconhecia alguns objetos que the pertencia, como sua blusa e sua mochila. Um dia "tinha outra bolsa igual, aí ele confundiu. Aí ele abriu e viu que não era a dele, que não tinha as coisas dele ali." Ele também demonstrava que sabia o que era dele, o que era de outra pessoa e o que era da escola porque guardava os objetos nos seus respectivos lugares. "O que é dá escola ele guarda lá na caixa ou no pote [...] as coisas que ele coloca na bolsa, ele sabe que é dele [...] ele sabe que aquele brinquedo que tá lá, ele sabe que é dele, depois ele devolve." Também demonstrava cuidado com relação aos objetos. Ele sabia quais eram os seus próprios brinquedos, porém gostava mais dos brinquedos dos colegas e costumava trocar o seu com o deles constantemente. "O brinquedo dele não atrai. Ele prefere pegar o do colega." Mesmo solicitando que deixasse ele mesmo escolher o brinquedo que iria levar, professora Yara achava que era sua mãe quem o escolhia. No início do ano era comum ele rasgar os bilhetes antes de entregar para a mãe. No fim do período de coleta de dados às vezes ele fazia isso. "Outro dia eu dei um bilhete na mãozinha dele e ele foi lá e deu para a mamãe e falou para ela que tinha sido eu que tinha entregado. A mãe perguntou: 'foi a Yara?' E ele disse: 'Não. Foi a Ne' [como ele chamava a Marlene]".

No início do ano, o aluno sentava cada dia "em um lugar diferente escolhido por ele". (Yara). No fim do ano ele sentava sempre em um mesmo lugar.

Quando em alguma atividade tinha um obstáculo que Ítalo Júlio achava que não iria conseguir ultrapassar, ele ficava olhando e não se arriscava. Por exemplo, quando ia jogar bola ao cesto se percebia que a distância era muito grande, ele não jogava, esperava que alguém diminuísse a distância ou se aproximava para poder jogar e acertar. "Ele faz pensando no sucesso que ele vai ter. Daí ele se aproxima do cesto." (Yara).

Professora Yara tinha o costume de formar fila com os alunos para eles irem de um lugar para o outro da escola. Trabalhou bastante com Ítalo Júlio para que ele 
soubesse a hora que tinha que formar fila e o respeito a ela. No começo ela tinha que avisá-lo para ir para a fila e orientá-lo para que respeitasse o seu lugar. Com o passar do tempo, quando a professora falava que era hora de ir para o parque ou para a merenda ou para outra atividade que ele sabia que tinha que formar fila, ele já se movimentava para ir em direção ao local em que normalmente a realizavam e respeitava o seu lugar. "Ele já sabe que ele tem que ir na fila, que não pode cortar na frente dos outros." (Yara). Além da hora de ir para a fila, o aluno saía do seu lugar para realizar outras atividades da rotina, como ir ao banheiro, escovar os dentes, ir tomar café no refeitório, pegar a folha para desenhar, buscar sua pasta, nos jogos, na hora de escutar música e de dançar. Do contrário, costumava ficar no seu lugar.

Ítalo Júlio durante o ano todo não se interessou por atividades gráficas. No começo só rabiscava a mesa e não o papel. Depois começou a rabiscar a folha mas só usava uma mesma cor. Realizava algumas garatujas na folha, utilizando-se mais de cores escuras (preto, azul escuro e vermelho). Às vezes a sua folha ficava mais colorida. Yara precisava incentivá-lo para que ele mudasse de cor: “oh, vamos usar outras cores?' Aí ele pega outras cores". Às vezes mostrava para outros a atividade que havia feito. Assinava o desenho do seu jeito e deixava a folha em cima da mesa. Seus colegas guardavam o desenho na pasta dele. Depois que terminava de fazer a sua atividade levantava-se e ia olhar o que os outros colegas estavam fazendo. "Ele vai, fica olhando o que os outros estão fazendo". (Yara). Quando realizava atividades no papel, precisava de um tempo maior que os demais alunos para se adaptar a ela e também necessitava da ajuda dos colegas como na hora do recorte, pois não conseguia fazer o movimento sozinho. Para procurar alguma figura na revista também precisava de um tempo maior.

$\mathrm{Na}$ hora da merenda ele demorava um tempo maior que os demais alunos para comer, quando comia. "Tem hora que ele está comendo, tem hora que ele sai, tem hora que vai brincar e depois ele volta". (Yara).

Segundo a professora Regiane ele demonstrava reconhecer a rotina da escola "porque tudo aquilo que a gente vai fazer a gente fala, então ele vai e faz. Se a gente fala:' vamos tomar café', ele vai e faz. Se fala: 'vamos escovar os dentes', aí ele vai. Se fala: 'vamos subir e arrumar as cadeiras', ele vai e tenta ajudar’. As professoras tinham que chamar a atenção do aluno para lembrá-lo da sequiência desta rotina. Mas 
ele sabia que depois de ir ao banheiro, tinha que lavar as mãos; depois de comer, tinha que levar o prato e a canequinha na bacia e que depois tinha que formar fila para subir. Ele ia ao encontro das atividades quando elas eram realizadas. Quando ele era avisado da atividade da seqüência da rotina, ele pegava os objetos necessários para realizá-la. Na última entrevista, Yara relatou que ele estava com um pouco de dificuldade para compreender a rotina porque esta estava alterada com a mudança do projeto da escola.

As atividades de música e de dança eram as que ele lembrava mais espontaneamente na rotina da escola. Estas também eram algumas das atividades prediletas do aluno. Ficava muito atento para acompanhar o ritmo da música com seus passos, gestos e fala. Cantava do seu jeito as músicas.

Outro dia nós estávamos cantando, ai veio uma professora e cantou a música de outra forma. De forma errada. Ai ele ficava: "não, não!" Olhando e ficava falando não. Acho que ele pensava: 'ela está cantando errado. Não é assim.' Aí ele ficava só no não. Ele percebeu que ela estava cantando errado, que não era daquela forma [...] se foi cantada ou ensaiado alguma música. Se a mãe dele pergunta se ele dançou, ele já fala até o nome da cantora. Que nem outro dia nós estávamos dançando e cantando a música da Xuxa e ai na hora de ir embora a mãe dele perguntou se ele tinha dançando. Aí ele falou "Xuxa." Não "Xuxa" né, mais dava para entender que era Xuxa. Então ele já conhece algumas músicas. Então para ele fica fácil, você percebe que ele gosta de música, dança, ele gosta bastante. (Yara).

Ítalo Júlio também gostava muito das atividades do parque. No começo ele precisava de ajuda para subir na balança e cavalinho. Com o passar do tempo não precisava mais que alguém o auxiliasse. Gostava de ir ao escorregador. Não descia sentado, só deitado. No começo necessitava de auxilio para subir as escadas. Depois aprendeu a subir sozinho. Para descer ele ficava gritando o nome da professora Yara para auxiliá-lo. Este auxílio ora era com a mão da professora, ora era só por meio do incentivo através da fala dela. "Ele sobe as escadas do escorregador, mas ele não quer descer. Não sei se é medo ou alguma coisa, ele sobe, mas para descer a gente tem que dar uma mão [...] Aí se fala, fica conversando com ele, tem hora que ele solta, ai ele vai." Nas nossas entrevistas conversamos bastante sobre este fato.

$\mathrm{O}$ aluno sempre ia à secretaria brincar com o telefone. $\mathrm{O}$ pegava e o utilizava como se estivesse mesmo falando com alguém. "Ele entra na secretaria, pega o telefone, liga para o pai dele, conversa assim como se estivesse mesmo falando com o pai. Explica, pergunta para o pai se está trabalhando". Marlene entendia que ele falava isso porque "as primeiras palavras dão a entender". Se o telefone da 
professora Alessandra estava à vista, "ele senta na minha cadeira, cruza a perna assim, aí fica falando com o pai assim: 'pá... oi ... tô aqui... tá... beijo.' Ele mesmo desliga o telefone e põe na mesa. [...] eu acho que ele já está numa imaginação."

Como contamos anteriormente, era freqüente Ítalo Júlio entrar na sala da professora Alessandra. Ele gostava de realizar algumas brincadeiras com a turma. Em uma destas ocasiões

O Júlio passou pela sala, ele já sentou no círculo sem saber que brincadeira era [os alunos estavam brincando de cabra cega]. Aí eu falei: deixa ele aqui e vamos ver o que ele faz, né? E ele prestou atenção que tinha que comandar a criança [para que ela achasse a saída do círculo que as crianças fizeram]. Então ele começou: "vai, vai... vem." Ele falava enrolado, mas a gente sabia que era "vem", ele fazia gestos. Aí eu coloquei o lenço nele e ele começou a andar para lá, e todo mundo em silêncio. Eu falei:" se todo mundo gritar vai atrapalhar, portanto só uma criança fala." Então a criança falava: "vem Júlio!" E ele seguia aquela onde estava mais perto o som, ele ia por onde estava o som. Daí a criança falava: "agora para!" $E$ ele parava. Então ele entendeu inteirinha a dinâmica da brincadeira. [...] quando ele achou o lugar, foi uma vibração dele! Aí toda hora ele queria colocar o lenço para brincar.

Esta era uma brincadeira que indicava para a professora Alessandra e para a professora Yara que ele compreendia o que era para fazer quando eram dadas as instruções: corre, pára, está em cima, está em baixo, para trás, para frente, para o lado. Elas achavam que ele ainda não sabia identificar o que era direita ou esquerda.

Para a professora Yara, "o Ítalo compreende algumas tarefas realizadas no dia a dia da escola como brincadeiras (lencinho na mão, bola ao cesto, batata quente $e$ outras)." Na brincadeira de lencinho na mão ele inicialmente tinha dificuldade para correr, mas com o passar do tempo, isto ficou mais fácil para ele.

Ele também gostava bastante da brincadeira de esconde-esconde. Nesta brincadeira "ele vai contando, ele vai até o cinco, depois ele vai direto para o trinta, 'cinqüenta e já!' Ele mesmo vai procurar e se esconder." (Alessandra). Professora Regiane observava que ele chamava os alunos para brincar de esconde-esconde.

No início do ano "os brinquedos preferidos do Júlio são carrinhos e jogos de montar ou encaixar". Os carrinhos são aqueles "diferentes, que tem tipo luzes, que anda sozinho." (Yara). Às vezes olhava estes carrinhos andar atentamente, parece que percebia que o brinquedo andava mais rápido do que ele. Tinha vezes que ele pegava um carrinho comum e ia para o chão. "Outras ele ficava na própria carteira brincando com o carrinho. Às vezes vai no grupinho junto com os colegas." Com os jogos de montar ele tinha um pouco de dificuldade. O monta tudo era mais fácil que 
os pinos mágicos. Às vezes preferia o tubo de cola do que os brinquedos. Com o passar do tempo foi se interessando também por massinha, bonecas, fantoches, brincadeiras de casinha, de teatro, com tinta e com e com areia.

Na brincadeira com massinha ele "mexe, olha o que o colega está fazendo... aí volta na massinha dele. Tem vez que ele quer trocar. Vai pega a massinha do colega. [...] Tem hora que ele faz bolinha, tem hora que ele faz cobrinha. Ai tem hora que ele para vai ver o que o colega está fazendo." (Yara). Ítalo Júlio parecia não atribuir significado prévio ao que estava fazendo com a massinha ou com os jogos de montar. Ele concordava com a atribuição de significados feito por outros para sua produção.

Ítalo Júlio gostava "muito de brincar com a boneca. Não sei se chama atenção [...] ele pegou a bonequinha a estava sacudindo, acho que da mesma forma que ele faz na casa dele e tentando cantar. Eu não entendia a musiquinha. Mas ele estava como se estivesse nanando mesmo uma criança. Ele chocalhava assim." (Yara). Ele sabia que não podia deixar a boneca cair. A tratava como um neném, com cuidado e carinho. Ele gostava de brincar de casinha "Ele ficou um bom tempo lá, com o pessoalzinho em volta, tinha papai, mamãe. O filhinho era a boneca. E tinha o irmãozinho maior que era uma outra criança. Aí ele ficou naquele grupinho durante um bom tempo."

Quando ele vai brincar na areia, "ele se empolga fazendo o que o colega tá fazendo [...] ele observa e faz". Ele gosta de brincar com tinta porque "ele gosta de mexer muito com água." (Yara).

A professora Alessandra brincava muito com Ítalo Júlio com o fantoche "Lolo".

Uma vez eu estava fazendo uma brincadeira com as crianças e colocaram ele na mesa com outros fantoches, né? Da primeira vez que ele viu assim esse Lolo eu estava brincando com os meus alunos e ele se encantou. E eu comecei a me dirigir a ele com o Lolo, o Lolo falava com ele. Aí ele veio querer beijar o Lolo, o Lolo tem um bocão, eu fingi que o Lolo pegava ele na mão. Então o tempo todo acho que chamou muito a atenção dele isso, não sei se ele vê na televisão o louro José também, né? Então agora eu falo: "vamos pegar o Lolo?” Aí ele já vai comigo no lugar em que ele sabe que o Lolo dorme. No começo ele me chamava de Lolo. Aí eu disse para ele: "eu não sou o Lolo! O Lolo é o boneco." Ele associava a pessoa ao boneco [...] Ele quer abraçar tanto, e o boneco é de espuma, então já está começando a rasgar, né? Então eu falo: "o Lolo quer carinho, não machuca o Lolo, faz dodói." Ele está começando a pegar o boneco com mais tranqüilidade, né? Antes ele ficava bem alvoroçado quando pegava o Lolo. E eu faço a fala do Lolo e ele conversa com o Lolo, ele responde. 
Falando sobre a brincadeira do aluno com o fantoche Lolo, Yara disse que "ele coloca os dedinhos lá no fantoche e fica olhando, agora se vocêfalar com o fantoche mesmo ele colocando os dedinhos ele fala, mesmo ele com entrando com a mão dele no fantoche, como se fosse ele e a gente falando ele responde, fala... fica olhando."

Ítalo Júlio mostrava um interesse e compreensão progressiva pelos brinquedos do cotidiano da escola.

Teve um momento na minha sala, lá tinha um ursinho que tocava música, mas você tinha que apertar a mão do ursinho. E ele ouviu a música, ele ficava ouvindo que era o ursinho, ele tentava fazer o ursinho tocar a música mas não sabia onde que ligava. Parou de tocar a música, ele pegou o ursinho e chocalhava, ele ficou nervoso. E aí a Yara falou para ele: “aperta no braço." Ele pegou no braço do ursinho e apertou. Ela não fez para ele, ele ficou nervoso, ela falou para ele: “aperta no braço Júlio." Ele foi e apertou. Aí tocou a música e parecia que ele tinha descoberto a América, né? [...] Aí ele ficou repetindo o tempo todo sem parar porque aquilo agradou para ele, né? (Alessandra).

Yara percebeu que com o passar do tempo em várias atividades ele não precisava mais ajuda de colegas.

Música, dança, futebol, agora ele vai sozinho. Nos jogos, nas brincadeiras ele se empolga bastante. Agora tá indo fazer qualquer tipo de jogos, brincadeiras, de danças, quando... quando passo um que é difícil para ele tá fazendo, as vezes ele fica olhando, observa, mais ele tenta fazer mesmo eu aumentando o grau de dificuldade.

Ítalo Júlio passou a preferir brincar com colegas do que brincar sozinho. No início era preciso que algum colega fosse o chamar para brincar. Depois ele se aproximava e procurava os colegas espontaneamente quando tinha vontade.

Uma brincadeira que fazia para chamar a atenção dos outros era fingir que caía quando estava jogando futebol.

Eu acho que ele está fazendo gracinha. Ele sabe que ele fazendo gracinha todo mundo vai em cima dele e assim fazer com que ele seja o centro da atenção. Uma vez nos jogos ele viu um menino cair. Aí o menino caiu e todo mundo foi acudir o menino. E ele também fingiu que caiu, fingiu que caiu e estatelou assim. Aí todo mundo foi em cima dele e ele gostou disso, né? Ele gostou de ser o centro da atenção naquela hora. (Alessandra).

Ítalo Júlio durante o ano não demonstrou muito interesse em assistir programas de T.V. e fitas de vídeo. Não prestava atenção. Deitava como se estivesse em sua casa. No fim do ano estava se interessando apenas pelo por um programa de T.V. " $a$ única coisa agora que eu vi que ele tá assimilando, que ele tá prestando atenção é o novo programa da Xuxa: No Mundo da Imaginação. Não sei se é porque tem criança e tem música ... eu acho que tá despertando a atenção dele." (Yara). 
Logo no início do período que coleta de dados professora Yara contou que ele sabia que tinha cinco anos e sabia algumas cores. Na última entrevista, Yara contou que ele tinha alguma noção de quantidade. Ele contava até cinco. Sabia dizer quando tinha um lápis separado. Conhecia os números um, dois e cinco. Reconhecia as letras do seu nome (as identificava no meio de outras) mas não sabia nomeá-las. Ele sabia quais eram as cores: vermelho, amarelo, azul, verde e branco. As cores mais apagadas ele não reconhecia. "Se você perguntar, ele fala as cores [...] se você perguntar a cor, ele responde. As cores ele sabe." (Yara).

Segundo Yara,

Fotos também chamam bastante a atenção dele. No dia das mães foi feito uma programação com as mães. Teve dança, jogos, competições com as mães e depois eu tirei foto e levei dois, três dias depois para eles estarem observando, olhando e ele viu que ele estava lá. Ele se identificou. Ele viu a mãe dele e falou: "mãe."

No começo do trabalho com Ítalo Júlio, Yara achava que ele não sabia que a imagem refletida no espelho era sua. Na última entrevista ela disse que ele se reconhecia porque quando ele ficava em frente ao espelho ele "ficou uns três ou dois minutos ele se olhando." Neuza disse que ele se reconhece no espelho. "Já percebi no cabelo, às vezes o cabelo fica mais levantado né, ai ele já começa a por a mão [...] quando ele acha que tá feio alguma coisa, ele põe a mão assim no cabelo: 'eta mãe', ai eu falo: 'seu cabelo, olha como tá'."

No início do período de coleta de dados, a professora Yara respondeu que suas expectativas com relação ao desenvolvimento de Ítalo Júlio eram:

Espero que ele tenha uma boa socialização com os colegas e profissionais que trabalham nesta unidade escolar. Continue participando e sendo espontâneo em suas atitudes, gestos palavras e frases que irei ajudá-lo à construir no decorrer do ano. Como adora música, danças, jogos e brincadeiras tentarei explorar nessas atividades o máximo de sua atenção e interesse utilizando como instrumento de trabalho o seu desenvolvimento.

No fim do período de coleta de dados Yara disse que "uns oitenta por cento" das expectativas que tinha com relação ao desenvolvimento e a aprendizagem do aluno foram atingidas.

Ele avançou mais do que eu esperava. Que nem subir e descer as escadas a comer sozinho, ir no banheiro que ele não ia, ele fazia nas calças, ele já consegue ir. Há muito tempo que ele não faz xixi na roupa, no começo do ano era direto. A colocar o mingau, antes ele passa o mingau na cabeça. Acho que eu vendo que tinha que tratar igual e que não era tão difícil quanto eu imaginava, até para mim que nunca tinha tido nenhum, e com um já é difícil, imagine você ter três na sala. Serviu para mim adquirir experiência que eu não tinha com alunos portadores de necessidades especiais eu não tinha. Cheguei até a conversar com as mães para terem paciência, 
que ia ser mais difícil, um pouco complicado, que tinha coisas que a gente ia poder fazer, outras ia ter mais dificuldade em estar fazendo. Houve compreensão dos pais, ajuda até das próprias crianças, os funcionários ajudaram bastante. Até ir no parque, que no começo eu não ia. Eu tinha medo de ir ao parque. Fiquei um mês sem ir ao parque. Se não tivesse nenhum aluno portador de necessidade especial eu já teria ido na primeira semana. Para eu adquirir minha autoconfiança, minha confiança demorei um mês. Ai eu conversei com a dirigente que não dava para ir no parque sozinha, que eu precisava de alguém para estar ajudando.

\section{As expectativas de sua mãe com relação a escola eram:}

Aqui na escola, eu espero que assim, aprenda assim ... não vou dizer que ele aprenda a ler, escrever. Mas que ele aprenda assim, a se vestir sozinho, a comer sozinho, a se relacionar bem com as pessoas, que é um problema que ele não tem. Todo mundo quando ele entrou aqui, todo mundo começou a perguntar: "Ah ele é agressivo ?" [...] para mim o objetivo maior, acho que tem que segura, o maior objetivo é esse da independência mesmo, que nunca não vai ter mãe e pai e irmã todo. Ele tem só uma irmã, ela tem a vida dela, ela não vai poder ficar ali, o meu objetivo é esse."

\section{Yara achou que Ítalo Júlio desenvolveu}

a parte de coordenação e individualidade, fazer as coisas sozinho. Independência. Acho que ele desenvolveu bastante. Como estava no começo do ano e como está agora eu acho que teve um grande progresso, até na própria fala, que a gente não entendia nada e agora a gente entende. Não há necessidade de um ficar perguntando para o outro o que ele está falando. A gente consegue entender. Até nos próprios gestos, se locomover, descer e subir escadas. Jogar bola, que antes ele não jogava. Subir e descer escadas, ir no escorregador que ele não fazia. Servir a merenda que no início do ano ele não fazia e agora já está fazendo, eu acho que ele progrediu bastante.

\section{E, ele aprendeu}

a se virar sozinho, a independência dele, ele consegue fazer muitas coisas sozinho. Porque aqui na escola ele não vai ter muito a ajuda do colega, que ele vai ter que fazer e em casa ele não faz. Tem coisa que ele faz aqui na escola que em casa ele não faz. Eu acho que ele já progrediu bastante.

\section{Segundo os demais profissionais da escola}

Eu percebi que ele desenvolveu bastante. Mesmo porque ele era assim dependente demais da mãe! [...] Ele era muito tímido, ele entrava na secretaria e ficava quietinho. Agora ele vai, ele mexe em alguma coisa que chama a atenção dele. Agora a gente vê que aos poucos ele foi desenvolvendo." (Marlene).

"Ele tinha timidez. Acabou a timidez, ele está mais comunicativo, hoje ele é participativo. Quer dizer, muito mais independente, dentro da dependência que ele tem ele se tornou bem mais independente! [...] Ele já está fazendo tudo sozinho, ele vai e se serve sozinho. Quando é uma coisa assim que a gente vê que está perigoso para ele a gente vai e dá uma mão, mas agora ele já vai para a mesa sozinho, vai para o banheiro sozinho. É um avanço, porque ele chegou aqui e dependia de tudo. Agora ele está subindo a escada, ele não precisa mais da gente para fazer isso.(Regiane).

Eu acho que ele está fazendo gracinha. Ele sabe que ele fazendo gracinha todo mundo vai em cima dele e assim fazer com que ele seja o centro da atenção. (Alessandra). 


\section{Para sua mãe ele}

aprendeu bem a comunicação. A fala melhorou. Ir ao banheiro, que ele fazia direto xixi nas calças, não pedia. Agora ela falou que ele já tá pedindo, ele vai. Em casa ele não pede, ele vai sozinho [...] ele começou a fazer em pé o xixi [...] o que eu acho legal, que as pessoas sabem que ele tá falando [...] saber também brincar com as outras pessoas, com as outras crianças... ele ficava só do lado, olhando brincar, não participava. Mesmo na outra escola, ele não participava mesmo das brincadeiras com as outras crianças. Apesar de ser pouquinhas crianças, seis crianças só na sala dele, ele não participava muito, o professor que as vezes trabalhava com ele contou essas coisas assim [...] ele tá mais assim na fala, que eu to percebendo [...] [ele está] pulando, pulava agora ele fica assim "mãe ó, ó.. ó mãe", que ele ganha, até ele tá se divertindo, porque não tinha acho que a perna dele não dava para ele sustento. Ele pulava chegava muito perto do chão. São essas coisas que para as outras pessoas é besteira, mais para a gente é importante.

Na entrevista final de coleta de dados Yara disse que descreveria Ítalo Júlio

como uma criança mais confiante, mais independente. Pelo menos eu acho que uns setenta por cento da independência dele ele conseguiu adquirir. Hoje é praticamente uma outra criança, não é a mesma criança que eu vi no começo do ano, que tinha uma série de dificuldades, uma série de barreiras, uma série de coisas que ele não fazia e atualmente está fazendo. Eu acho que teve um grande progresso. Não sei se vai ter alguma dificuldade o próximo professor que vai estar pegando ele. Porque a mãe dele já está insegura, já está perguntando com quem ele vai ficar ano que vem, se eu vou ficar aqui, porque o destino é incerto, minha sede não é aqui é na outra escola. Ela estava perguntando se ele tinha condições de estar indo para a fase três. E ai eu falei que para a independência dele ele vai ter que se socializar, que ele vai ter que aprender que tem mudanças.

\subsubsection{Uma possível síntese da história de Ítalo Júlio}

Segundo as observações da professora Yara, dos demais profissionais da escola e de sua mãe, depois de um ano letivo de freqüência e participação nas atividades cotidianas da escola, Ítalo Júlio estava uma criança "diferente". Que diferença era essa? Por quê estava diferente?

Ao descrevermos a história do aluno, observamos mudanças relacionadas ao aprendizado e ao desenvolvimento sensorial, motor, cognitivo, afetivo, social e conseqüentemente da autonomia do aluno. Estas mudanças são diferenças que as pessoas que conviveram com Ítalo Júlio perceberam. Elas aconteceram na medida em que o aluno se relacionava com as pessoas, com o espaço, com o tempo, com os objetos e com as atividades de seu cotidiano escolar.

$\mathrm{Na}$ relação com as pessoas Ítalo Júlio teve a possibilidade de experimentar várias formas para se comunicar, demonstrar e buscar o que desejava. Progrediu na comunicação oral, pronunciando mais palavras que passaram a ser compreendidas 
pelas pessoas que conviveram com ele. Apreendeu a pronunciar o nome de alguns colegas e da professora. Reconhecia pelo nome alguns colegas, professores e funcionários da escola. Ele diferenciava pessoas conhecidas das que ainda não conhecia. Era mais retraído com estas últimas. Aprendeu a prestar atenção e responder aos outros quando solicitado. Aprendeu a agradecer quando alguém the fazia um favor, responder chamada e a se reconhecer também pelo nome Ítalo. Antes somente atendia quando chamavam-o de Júlio. Aprendeu a se aproximar dos colegas para brincar com eles quando a brincadeira agradava-o. Aprendeu a recusar ajuda de pessoas quando se sentia capaz de realizar determinada atividade sozinho, como descer as escadas do prédio da escola e solicitar ajuda de colegas para realizar alguma atividade que não conseguia fazer sozinho. Aprendeu, também, a fazer coisas que não são permitidas para chamar a atenção de outras pessoas para si.

Ítalo Júlio foi incentivado a ir ao banheiro e a fazer as etapas exigidas para realizar a atividade de fazer xixi, lavar as mãos, escovar os dentes, utilizando seus próprios recursos sensoriais, motores e cognitivos. Às vezes, alguns colegas ou outros funcionários tinham atitudes de querer ajudá-lo em situações que ele já era capaz de resolver os problemas advindos dela sem ajuda. Quando isso acontecia, a professora Yara explicava para os outros a importância dele resolver o problema sozinho, ou também, ele mesmo insistia para resolver a situação, mesmo com dificuldade.

O aluno foi incentivado a andar pela escola com suas próprias pernas e não no colo de outras pessoas. Foi incentivado a descer e subir as escadas do prédio e do escorregador, a ir aos brinquedos do parque, correr atrás da bola para jogar futebol, a ir à sala da diretora ou a outros locais da escola para pegar algum material necessário para ele, para a professora ou para todos os alunos. Foi incentivado a explorar o espaço colocando em movimento seu corpo e as funções cognitivas que se desenvolvem neste movimento. Tudo isso contribuiu para que ele aprendesse a subir as escadas sozinho apoiando a mão no corrimão, andasse em lugares retos com mais facilidade, arriscasse a correr nas brincadeiras de bola, esconde-esconde, corre-cotia, a seguir as orientações dadas pela professora para ir a um determinado local da escola e, a ir a outros, dando como referência somente o nome do local para aonde deveria ir. 
O hábito dos alunos se organizarem em fila contribuiu para que ele, ao longo do tempo, aprendesse a respeitar o lugar em que deveria ficar nestas ocasiões. Ao ser solicitado para pegar e guardar os seus objetos de uso cotidiano, aprendeu qual era o local em que eles eram guardados. Cuidava de seus pertences e era o responsável por guardar seu material na mochila. Com o passar do tempo aprendeu a localizar, sem que alguém o orientasse, onde era o local para sentar-se. Passou a não mais necessitar de ajuda para sentar-se e levantar-se da cadeira, como era necessário no início do ano letivo. Movimentava-se para ir buscar sua pasta de atividades, para observar o que os outros colegas estavam fazendo, para participar das atividades da rotina da escola, como ir ao banheiro, ir à merenda, ir ao parque, ir dançar, ir pegar os brinquedos e jogos no armário, ir buscar o papel higiênico para limpar seu nariz, entre outras.

A professora Yara e outros profissionais da escola reconheciam que ele necessitava de um tempo maior para ele realizar algumas das atividades da rotina, como as de procurar uma figura na revista, recortar, escolher o que desejava comer, servir-se e comer sozinho. Antes da mudança do espaço físico e da ordem das atividades da rotina no mês de outubro, Ítalo Júlio conhecia a sequiência das atividades quando dado alguma dica da próxima atividade que seria realizada. Nas atividades de música e dança, acompanhava com freqüência o ritmo de cada uma com seus passos, gestos e fala.

Com o hábito de mostrar a importância de cuidar dos objetos e dos mobiliários da escola e solicitar que os alunos limpassem a sujeira que fizeram na mesa, por exemplo, a professora Yara contribuiu para que Ítalo Júlio deixasse de rabiscá-la. Segundo ela, ele aprendeu que se rabiscasse a mesa, ele teria que limpá-la. Era permitido e incentivado aos alunos que emprestassem os seus brinquedos aos colegas. Esta situação permitiu que Ítalo Júlio reconhecesse seus brinquedos e experimentasse manipular e observar outros de seu interesse. Ele brincava com os brinquedos de acordo com a sua função. Imitava bastante o que os colegas faziam com os brinquedos. Gostava bastante de brincar com o telefone e demonstrava muita coerência nesta brincadeira, assim como, na de cuidar de bonecas. Durante as brincadeiras e outras atividades da escola, Ítalo Júlio experimentou abrir e fechar a caixa dos brinquedos, rosquear e desrosquear os potes em que ficavam guardados 
lápis, canetinha, blocos de montar, massa de modelar. Brincou várias vezes de monta- tudo e com o "Lolo", fantoche que lhe incentivava a falar, elaborar histórias simples, e tentar coordenar os seus dedos para movimentar o boneco.

A professora Yara teve o cuidado de adaptar, quando necessário, os objetos e/ou as formas e/ou o conteúdo das atividades para que ele pudesse realizá-las. Um exemplo disso é percebido quando ela diminuía a quantidade de suco ou leite da jarra para que ele tivesse força e coordenação para poder colocá-los no copo.

Em algumas atividades do cotidiano, Ítalo Júlio necessitava de algum tipo de auxílio de outro colega ou da professora, como para realizar o movimento do recorte com a tesoura, ser bastante incentivado para desenhar ou pintar na folha de papel, precisar do reforço oral ou dar a mão à professora para descer do escorregador. Embora as atividades com folha não despertassem muito o interesse do aluno, a professora sempre pedia para ele realizá-la e a mostrar aos outros o que havia feito. Quando terminava sua atividade, levantava e observava o que os colegas estavam fazendo.

Nas brincadeiras com massa de modelar e de monta-tudo, também queria imitar o que os colegas faziam. O contato com os colegas e o fato de querer imitar o que eles ou outras pessoas realizavam, contribuiu para que Ítalo Júlio experimentasse fazer várias atividades da rotina da escola. Para compreender algumas delas ele necessitava que lhe fosse explicado com muita ênfase o que era ou, o que não podia ser feito, como o caso de não deixar molhar a roupa quando lavava a mão. Na roda de conversa, ficava observando o que os outros falavam e faziam, no final do processo de coleta de dados, ele já respondia com algumas palavras o que lhe era questionado. Sua atenção era muito boa e foi constantemente requerida nas atividades com música e com dança. Passou a prestar mais atenção em programas de T.V. quando estes tinham crianças, histórias, músicas, danças ou outras coisas as quais ele gostava.

Nas brincadeiras de corre-cotia, esconde-esconde e cabra-cega, Ítalo Júlio prestava atenção e acompanhava algumas etapas destas atividades. Elas colaboraram para que ele corresse, abaixasse, levantasse, fosse para um lado e para outro, chegasse mais perto ou mais longe dos objetos ou pessoas que faziam parte da brincadeira. Estas habilidades e noções foram desenvolvidas gradualmente ao longo 
do trabalho desenvolvido com o aluno. A contagem que tinha que fazer com os olhos fechados na brincadeira de esconde-esconde era uma das atividades desenvolvidas que colaborou para que ele desenvolvesse algumas noções de quantidade. Segundo a professora Yara ele também aprendeu, na relação com as atividades, a reconhecer os números 1,2 , e 5 , as cores vermelho, amarelo, azul, verde e branco e a identificar algumas letras usadas para escrever seu nome.

Ítalo Júlio teve a oportunidade de passar margarina ou geléia no pão ou bolacha várias vezes. Passou a gostar desta atividade e a querer realizá-la sozinha, embora com dificuldades na coordenação motora e de precisar de um tempo maior para poder realizá-la.

Depois das férias e da mudança para salas ambientes na organização curricular da escola, Ítalo Júlio voltou a esperar, como fazia no início do ano, que alguém lhe desse a comida na boca. Alguns colegas do aluno queriam fazer isso por ele, mas a professora Yara intervinha para que ele mesmo o fizesse.

Pudemos observar que as interrupções na seqüência das atividades da rotina escolar, como no caso das férias e a mudança ocorrida na nova organização escolar, foram fatores que contribuíram para que ele deixasse de realizar com frequiência e numa mesma seqüência, algumas das atividades que ele havia demonstrado ser capaz de fazer. Os profissionais da escola, continuaram a investir no desenvolvimento e no aprendizado de Ítalo Júlio porque tinham conquistado a confiança de que progressos nestes termos eram possíveis.

Antes de finalizar esta síntese, gostaríamos de ressaltar o desafio que os profissionais da escola tiveram em conquistar a confiança da mãe para que ela se sentisse mais segura em seu filho freqüentar aquela escola e a perceber os benefícios que as relações naquele cotidiano escolar propiciava a ele.

A história de Ítalo Júlio expressa algumas relações de co-dependência que devem e podem ser transformadas em relações de interdependência para que pessoas com deficiência possam estudar em escolas regular e serem beneficiadas nas relações neste contexto. 


\section{DISCUSSÃO DOS DADOS}

Para realizarmos esta discussão, recorremos ao referencial teórico e ao material empírico desta pesquisa e nos arriscamos a fazer algumas extrapolações para contribuir na compreensão das questões propostas como objetivos neste trabalho.

Que tarefa difícil!

Consideramos difícil por várias razões. O processo de realização desta pesquisa foi muito envolvente por se tratar de um tema que é objeto de estudo e atuação profissional no cotidiano da pesquisadora. Por isso, será difícil atermos-nos a realizar relações às questões centrais da pesquisa. O cotidiano é muito rico de detalhes, o que deixa-nos tentados a extrapolar, extrapolar e extrapolar... Realizar uma pesquisa em uma visão construtivista e pesquisar a construção de um sistema complexo, como para nós é considerado uma educação inclusiva, "dá pano para manga". Porém, aqui estamos! E, portanto, "mãos a obra"!

As perspectivas teóricas apresentadas neste trabalho constituíram a base da proposição dessa pesquisa e, ao mesmo tempo, foram elaboradas de modo que o seu conjunto justifica o "porquê" as relações estabelecidas no cotidiano escolar em uma perspectiva inclusiva de educação beneficiam o desenvolvimento e a aprendizagem de alunos com deficiência. Isto é, em cada eixo teórico desse trabalho: Educação Inclusiva; Desenvolvimento e Aprendizagem; e, Cotidiano e Cotidiano Escolar, descrevemos enunciados e princípios que nos indicam que a vivência das relações estabelecidas em um cotidiano escolar que valorize e respeite as características de todos os alunos, pode contribuir favoravelmente ao desenvolvimento e à aprendizagem de crianças com deficiência. O material empírico desta pesquisa confirmou o que essas referências teóricas indicam e trouxe exemplos de relações que contribuíram para o progresso dos alunos. Algumas relações estão mais evidentes no processo do aluno Érick. Outras estão mais evidentes no processo do 
aluno Ítalo Júlio. Outras, ainda, ilustram alguns desafios que ainda necessitam ser superados para trabalharmos efetivamente na lógica inclusiva de educação. Queremos enfatizar as relações favoráveis que foram construídas nos cotidianos escolares em que acompanhamos. Consideramos que estas relações fortalecem e dão indícios das possibilidades que temos para alcançar.

Como pressuposto em um contexto que trabalha na lógica inclusiva de educação (MACEDO, 2001b), Érick foi compreendido e valorizado nas formas em que podia estabelecer as relações com as pessoas, com o espaço, com o tempo, com os objetos e com as atividades no cotidiano escolar. Os profissionais e os colegas da escola reconheceram que ele demonstrava o que queria e o que sabia por meio de gestos, expressões faciais, olhares, balbucios e até algumas palavras. Este reconhecimento foi construído na observação atenta, na convivência com Érick no cotidiano escolar. Encontramos indícios desta valorização nas palavras da professora Vilma, "quando uma criança que nem o Érick já se comunica dessa forma é porque ele já sabe se relacionar, da forma dele, mas ele já sabe. Ele encontrou formas para isso."

Érick também pôde viver relações de semelhança dentro do seu cotidiano. Ele levava bronca, experimentava todos os materiais que os demais alunos experimentavam, circulava por todos os espaços da escola, realizava as atividades que os outros alunos realizavam e passou a ficar com a professora substituta ou com outras professoras como acontecia com qualquer aluno quando a professora faltava. Este último fato não aconteceu sempre enquanto o aluno estudava nesta escola. Foi necessária uma reflexão sobre o porquê ele ia embora quando a professora faltava para que ela e o grupo dos profissionais percebessem a necessidade de eles se organizarem para que o aluno ficasse na escola nestas ocasiões.

O desenvolvimento e a aprendizagem de Érick e de Ítalo Júlio eram comparados com os seus próprios. Isto é, o progresso dos alunos tinha como dado inicial de comparação, como eles estavam num momento anterior, considerando os fatores que estavam interferindo em cada contexto vivido. Era constante durante as entrevistas as professoras comentarem como era a movimentação deles, a comunicação, a independência antes e no momento em que as entrevistas estavam sendo realizadas. Entendemos que em uma proposta de educação inclusiva, a avaliação do aluno deve estar a favor do seu progresso como sugerem as avaliações formativas propostas por 
Hadji (2001) e Perrenoud (2002). Neste sentido, o referencial para a avaliação do desenvolvimento e da aprendizagem do aluno não deveria ser o próprio aluno e o trabalho com ele realizado? Isto é, no trabalho com a diversidade, não é desejável a padronização do desenvolvimento de todos da mesma faixa etária, por exemplo. Não é desejável a comparação a partir de referências do desenvolvimento de outros senão a do próprio sujeito. Se consideramos todos diferentes, não temos como comparar o que não é de início igual. Não há um conteúdo determinado a priori. Este é apenas um dos meios para propiciar o desenvolvimento e aprendizagem, e não o fim em si mesmo.

Marcela, professora de Érick, chegou a fazer comparações de Érick com outros alunos com o objetivo de evidenciar o progresso do Érick e valorizar que a deficiência que ele tinha não prejudicava sua atenção, compreensão e realização das atividades. Ela nos contou que na brincadeira do pimpão, por exemplo, Érick tinha desenvolvido os esquemas necessários para participar da atividade e aprendido as regras, e outros alunos seus, ainda não tinham. Para ela, dependendo da atividade, ele tinha mais ou menos benefício que algum outro aluno, como acontecia em outras atividades com todos os seus alunos.

Marcela, professora de Érick, mostrou-se aberta à reflexão sobre sua prática e a revê-la conforme necessário. Um fato interessante que demonstra esta reflexão foi a situação que ela nos contou sobre a explicação que havia dado aos alunos da escola do porquê Érick não andava, nem falava. Ela percebeu que a explicação do botãozinho que havia dado (quando disse aos alunos que Érick tinha um botãozinho na cabeça que ainda não tinha ligado), trazia uma expectativa mágica ou de causaefeito, de que bastaria que alguém fizesse algo para que o botãozinho ligasse e ele aprenderia a falar e andar. Percebeu que esta informação trouxe mais problemas porque os alunos queriam achar onde estava o botãozinho do aluno para ligá-lo. Desta forma não permitiria que os alunos compreendessem a deficiência e as possibilidades de desenvolvimento e de aprendizado que Érick tinha.

As expectativas de Marcela ao longo do trabalho modificaram-se, talvez sem ela perceber. No início das entrevistas Marcela contou-nos sobre sua identificação com os anseios da mãe que estavam relacionadas a "você sonha em dormir e acordar no outro dia e seu filho estar falando". Ela nos disse que "queria que ele desenvolvesse 
a fala e a coordenação motora". Na última entrevista, ela disse que uma de suas expectativas no trabalho com o aluno durante todo o tempo em que ele estivesse na escola era a de

ver ele como parte integrante, mesmo com as dificuldades dele, mas que ele é capaz. de fazer [...] a minha meta, desde que ele entrou aqui no grupo foi nunca deixar ele fora de nada [...] ele tem que saber que existe um dia após o outro, que ontem foi vinte, hoje é 21, amanhã é 22. Nem que ele não consiga registrando, mas oralmente ele tem que ter isso.

Percebemos que a professora pôde separar suas expectativas das da mãe e vislumbrar outras ao longo do trabalho com o aluno. Pudemos também perceber uma coerência entre suas expectativas para o desenvolvimento do aluno com as intervenções no cotidiano da escola em que ela sempre pensava uma forma de ele participar, ter um benefício com o que estava sendo realizado, e também orientava seus alunos para deixarem que ele fizesse tudo o que lhe era possível sozinho, só auxiliando quando necessário. Este auxílio tinha o objetivo de fazer com que ele compreendesse o que estava acontecendo e, na medida do possível, em um momento posterior, poder estar realizando com mais autonomia esta atividade.

As expectativas de Yara no início do trabalho eram de que Ítalo Júlio tivesse uma boa socialização com os demais colegas e profissionais da unidade escolar e continuasse a ser espontâneo nos gestos e atitudes que ela percebia nele. No final do trabalho também observamos uma mudança em suas expectativas. Estas aconteceram ao longo do trabalho realizado, na medida que em foi percebendo outras necessidades e estabelecendo os objetivos no trabalho para com o aluno. Yara, na última entrevista, deixou indícios de que seus objetivos estavam relacionados a que Ítalo Júlio fosse mais independente, melhorasse sua coordenação motora e comunicação.

Como em um sistema complexo, observamos objetivos diferenciados para o trabalho com cada aluno considerando suas necessidades e possibilidades. Também observamos mudanças de estratégias quando estas foram consideradas necessárias. Um exemplo de mudança de estratégia foi quando a professora Marcela percebeu que para Érick, a proposta de desenho livre não o estava agradando, uma vez que ele tinha consciência que ele não estava conseguindo desenhar aquilo que ele gostaria. Assim sendo, ela passou a desenhar uma figura como ponto de referência na sua 
folha para ele preencher aquele espaço. $\mathrm{O}$ que era desenhado era algo relacionado à atividade proposta naquele dia ou a outro tema que o aluno havia trazido de casa.

O dinamismo dialético presente nos sistemas complexos das histórias é expresso quando lemos o relatório que a professora Marcela havia feito sobre o aluno, e que, segundo ela, naquele momento, expressava o que ela descrevia sobre o aluno, ela disse: “muita coisa que eu coloquei aí já mudou”. Ela considerava ser importante estar atenta às mudanças, pois: “demora para acontecer alguma coisa, mas quando acontece, vem uma atrás da outra. Então, você tem que ficar ali mesmo, senão você acaba perdendo.” Esta fala denota a consciência do desenvolvimento enquanto um processo em direção ao progresso e que este precisa ser acompanhado sistematicamente.

Apesar de Érick ter um comprometimento físico bem significativo, o que implicava a necessidade de ajuda para realizar atividades de cuidado próprio e várias outras do cotidiano escolar, sua professora, os colegas e a comunidade escolar, foram gradativamente construindo relações de interdependência com o aluno. Essas relações favoreceram que o aluno desenvolvesse habilidades para tomar pequenas decisões e realizar algumas partes das atividades cotidianas utilizando seus próprios recursos e assim, caminhasse para a construção da autonomia. Vinha (2000) lembra que, para a criança pequena conquistar sua autonomia é necessário que ela tome pequenas decisões no seu dia-a-dia. Érick era quem avisava a hora que queria tomar água, se queria sair do carrinho durante as atividades da rotina, se queria ou não determinado alimento, solicitava a participação do outro quando tinha alguma necessidade e, também, passou a sentir se já estava ou não na hora de trocar o seu babador.

Com o aluno Ítalo Júlio, também podemos perceber relações baseadas na lógica da interdependência, embora em alguns momentos percebemos outras ainda caracterizadas pela co-dependência. Professora Yara incentivava para que ele fosse no banheiro sozinho e fizesse as etapas desta atividade utilizando seus próprios recursos, porém algumas destas etapas eram simplificadas para evitar que o aluno "se molhasse" e passar pela dificuldade de abrir a pasta de dente e apertá-la. A atividade de limpar o nariz também era simplificada na medida em que o papel era dado na mão do aluno. Consideramos que estes poderiam ser desafios importantes para a 
construção da autonomia do aluno e serem trabalhados numa perspectiva da interdependência. A auxiliar de apoio operacional, Sofia, também expressou uma tendência presente no cotidiano de pessoas com deficiência. Esta é relacionada ao fato de que muitas vezes elas não precisam de ajuda, mas a pessoa que está próxima julga necessário auxiliar já que elas têm "problema".

Nas histórias de Érick e Ítalo Júlio, as relações entre os profissionais da escola e entre todos os alunos, na maior parte das vezes, também foram construídas de forma interpedendente e incentivando a autonomia dos alunos e dos profissionais. Por isso, podemos perceber as características de indissociabilidade, complementaridade e irredutibilidade nestas histórias. Nas duas histórias observamos um movimento de construção de uma identidade coletiva no trabalho dos profissionais. A idéia de que a ação da professora era tão importante quanto à da merendeira dentro do processo educativo era cultivada no cotidiano das escolas, respeitando as diferentes posições e especificidades de cada profissional. As ações também eram vistas como complementares. Tanto as ações dentro da própria escola, quanto da escola/família e da escola/instituições onde eles realizavam atendimentos terapêuticos. Felizmente não encontramos indícios de que os alunos eram reduzidos às deficiências que tinham ou a atributos estereotipados.

Os diferentes olhares dos diferentes profissionais e dos colegas que conviveram com Érick e Ítalo Júlio foram levados em consideração nas relações do cotidiano dos alunos em suas escolas. A professora Marcela valorizou o fato de termos realizado reuniões com todos os profissionais da escola porque considerou importante ouvir o que as outras pessoas estavam percebendo sobre o aluno e que ela, às vezes, podia não estar percebendo. Foi interessante quando fazíamos uma pergunta para todos os profissionais sobre alguma relação do aluno no cotidiano da escola e eles ficavam pensando por instantes e recordando o que cada um já havia observado. Os olhares sobre o que os alunos achavam que Érick ou Ítalo Júlio queria dizer ou fazer, também eram considerados pelos profissionais.

No cotidiano do trabalho com o aluno foi fundamental que os profissionais considerassem os vários aspectos envolvidos em uma determinada situação. Consideramos interessante o fato das professoras Marcela e Yara tentarem associar o que estava acontecendo com o aluno em sala de aula com situações que as mães 
traziam de casa, que outro profissional havia observado ou ainda que elas mesmas perceberam em outros momentos do cotidiano escolar do aluno. Marcela tinha muito o hábito de conversar com Regina, mãe de Érick, para saber as coisas que estavam acontecendo em casa para fazer uma relação com o que estava acontecendo na escola. Yara relacionava o fato dele ter dificuldade de andar, correr, de ainda querer ser alimentado por outras pessoas, não ao fato dele ter uma deficiência, mas sim ao fato de ele não ter oportunidade de realizar mais atividades que desenvolvessem essas habilidades no seu cotidiano fora da escola. Esta leitura compreensiva realizada pelos profissionais propiciou que algumas atividades fossem propostas com o objetivo de contribuir para o progresso do aluno, como por exemplo, Yara incentivar que Ítalo Júlio subisse e descesse as escadas e se alimentasse sozinho, o fato de Marcela trazer para roda da conversa assuntos de situações que estavam acontecendo em casa com Érick.

Quando todos os profissionais, ou parte deles, ou ainda as professoras e a mães trocavam informações e discutiam sobre algo relacionado ao trabalho com o aluno estavam atuando em favor de um compromisso coletivo. Havia a compreensão de que os conhecimentos dos outros profissionais ou da mãe poderiam contribuir para o trabalho com os alunos. Também, a responsabilidade sobre estes, eram compartilhadas entre várias pessoas, incluindo os próprios alunos. Podemos verificar nas histórias, que as professoras Marcela e Yara, na maior parte das vezes, agiam considerando que elas não eram as únicas responsáveis pelos alunos e não eram somente elas que poderiam auxiliá-los ou ensiná-los. Este fato é extremamente importante porque um dos problemas que freqüentemente encontramos nas práticas educacionais, com ou sem alunos com deficiência, é que o professor se vê como o único responsável pelo aluno e aquele que deve prover todos os cuidados e ensinamentos a eles. Estas atitudes não são favoráveis ao desenvolvimento da autonomia e da aprendizagem dos alunos e nem dos profissionais da escola. Além disso, ela torna uma educação inclusiva inviável, uma vez que o professor, dados os seus limites humanos, não consegue realizar com êxito várias tarefas que coincidem no cotidiano da escola. Como teria sido o trabalho com Érick se os demais alunos e colegas não tivessem cooperado nas atividades do cotidiano e se a professora 
Marcela não tivesse oportunizado para que ele solicitasse o que desejasse? Como teria sido o trabalho da professora Yara?

A reciprocidade, a solidariedade e a cooperação foram incentivadas nas relações vividas com os alunos. Lembramos que para Piaget (1932/1994), esses três elementos são indicadores da evolução cognitiva e afetiva das crianças. Quando somos capazes de cooperar é que podemos desenvolver nossa autonomia. Nenhum dos professores se "queixaram" que os alunos estavam "perdendo tempo" ao auxiliar Érick ou Ítalo Júlio. Elas achavam que além deles gostarem, eles também estavam aprendendo nestas situações. Consideramos que nas ações de reciprocidade todos os envolvidos estão pondo em funcionamento seus esquemas motores e cognitivos e, portanto, favorecendo seu desenvolvimento e sua aprendizagem. Valorizamos o desenvolvimento da autonomia, que para Piaget se conquistava em uma educação para a liberdade (1945/1998), como um dos objetivos primordiais em e para, uma prática inclusiva.

O propósito de nossa pesquisa não foi estudar diretamente o benefício para todos os participantes do cotidiano escolar dos alunos. Entretanto, podemos inferir ao ler as histórias e as considerações feitas ao longo desta discussão, que os cotidianos das escolas desse estudo contribuíram para todos os participantes do processo. $\mathrm{Na}$ história de Érick alguns profissionais citam o que eles estavam aprendendo com os alunos com deficiência. Lembramos que só poderemos falar de um contexto realmente inclusivo, quando as propostas educacionais proporcionarem uma educação de qualidade para todos os alunos independentemente de suas características físicas, psíquicas, cognitivas, culturais e sociais. O movimento por uma pedagogia diferenciada (ALCUDIA et al, 2002; ANDRÉ, 2002; MACEDO, em fase de elaboração; PERRENOUD, 2000a,) reafirma a necessidade de desenvolvermos praticas para garantir situações ótimas de aprendizagem para a diversidade dos alunos que compõe a sala de aula.

A nossa pesquisa confirmou a hipótese de Macedo (2002a, p.131) de que "todos podem aprender". Érick e Ítalo Júlio ao nascer tinham uma estrutura orgânica composta por algumas das características da paralisia cerebral e da síndrome de Down, respectivamente, e dos demais caracteres genéticos herdados de suas famílias. Esta estrutura foi colocada em movimento e desenvolvida nas relações com os 
elementos que compuseram os cotidianos destes alunos, dentre eles, o cotidiano escolar. Isto é, o desenvolvimento que eles puderam ter até o momento final da pesquisa, foi propiciado pela interação contínua que eles tiveram com o meio ao longo de suas vidas.

A escola, a educação infantil, é um dos ambientes fundamentais nos quais os sujeitos, como os alunos que participaram do nosso estudo, têm a oportunidade de vivenciar dois dos fatores considerados por Piaget e Inhelder (1968/1999) como responsáveis pelo desenvolvimento e evolução mental: as experiências e as interações sociais. Ítalo Júlio no seu cotidiano escolar experimentou brincar várias vezes com o fantoche Lolo. Ele queria sempre pegá-lo, ficava mexendo com ele para verificar qual era a reação deste objeto frente às suas manipulações. Juntamente com isso, a professora Alessandra, manipulava o mesmo objeto mostrando ao aluno algumas possibilidades de brincar com o fantoche. Esta interação social provocou que o aluno quisesse conhecer mais sobre o objeto. Ela foi fonte de perturbação, o que fez com que ele tivesse que mobilizar os seus esquemas de ação e/ou pensamento já desenvolvidos, para compensar estas perturbações e dar uma resposta adaptativa que lhe possibilitou brincar com o fantoche: tentava movimentar com seus dedos o boneco e conversar com ele, como normalmente acontece nessa brincadeira. Este processo é o que os autores acima denominaram como o quarto fator responsável pelo desenvolvimento: a equilibração. A maturação do sistema orgânico, físico e neurológico do aluno também foi o outro fator presente nesse desenvolvimento.

A brincadeira do "pimpão" realizada com grande frequiência na sala de aula do aluno Érick é uma atividade interessante para percebemos o que ele pôs em funcionamento para compreender a atividade e poder participar dela e, além disso, desenvolver noções de seqüência temporal, numérica e aprender a contar e saber qual era o dia do mês. Érick assimilou, por sua participação, as regras da brincadeira. Estas tiveram que ser incorporadas por ele, através da acomodação e modificação de seus esquemas motores e cognitivos. Érick desenvolveu um esquema para acompanhar o ritmo e contar (Marcela percebia porque acompanhava com o olhar a sequiência da brincadeira em cada aluno) e também esquemas motores, como a movimentação de sua boca para esboçar o som do número que estavam contando e o 
movimento do ombro e do braço que fazia quando chegava a sua vez na brincadeira. Isto é, Érick, pelo equilíbrio da assimilação e acomodação, se adaptou à brincadeira e deixou estabelecido um novo ponto de partida para a sequiência de seu processo evolutivo.

Valorizamos também a vivência das atividades do cotidiano escolar dos alunos pela oportunidade que oferecem de por em funcionamento os aspectos sensoriais e motores do desenvolvimento. Para Piaget (1937/2001), a inteligência sensóriomotora é a matriz de outras formas de inteligências que serão construídas e reconstruídas a partir desta estrutura desenvolvida no primeiro estádio. Não foi nosso objetivo na pesquisa verificar em que estádio do desenvolvimento cada aluno se encontrava. Entretanto, consideramos interessante apontar a importância que teve para o desenvolvimento deles as atividades que favoreceram alguns aspectos da inteligência sensória-motora. Gostaríamos de ressaltar que para Piaget, as fases do desenvolvimento são integrativas e universais. Isto é, o que foi adquirido em um estádio do desenvolvimento é integrado e reconstruído no próximo e segue a mesma seqüência evolutiva em todas as pessoas. Portanto, as experiências sensoriais e motoras continuarão sendo importantes para o desenvolvimento de todo ser humano ao longo da vida, embora sua importância maior esteja no primeiro estádio.

Como vimos na seção em que discorremos sobre o desenvolvimento e a aprendizagem de pessoas com deficiência, crianças com síndrome de Down têm como uma de suas características, a hipotonia (diminuição da tensão) muscular. Esta característica pode atrasar o desenvolvimento motor da criança. Na paralisia cerebral o desenvolvimento motor pode também ter um atraso ou até mesmo ser limitado. No caso de Érick, que tem paralisia cerebral do tipo tetraparética espástica, isto significa que ele tem uma tensão muscular acentuada em todos os membros de seu corpo. Portanto, ambos têm um prejuízo no seu desenvolvimento motor, sendo que em Érick, ele é bem mais acentuado. As crianças conhecem o mundo porque seus órgãos do sentido captam as informações provenientes do meio e cada uma delas gera uma resposta adaptativa ao meio. Num primeiro momento, esta resposta é essencialmente motora. Progressivamente ela se transformará em representação e linguagem. Frente a isso, podemos inferir que pessoas que têm um prejuízo no seu desenvolvimento 
motor, poderão ter atrasos ou dificuldades para dar seqüência ao seu processo de evolução mental por terem trocas deficitárias com o meio.

A criança conhece o mundo pela sua ação sobre os objetos, portanto, devemos propiciar muitas formas de ações motoras para que as crianças os conheçam, ou quando as possibilidades motoras são precárias, devemos buscar outras formas das informações serem captadas pelo sujeito.

Retomamos estas idéias porque queremos valorizar as aquisições que foram percebidas pelos profissionais das escolas no plano do desenvolvimento motor dos dois alunos. A professora Yara investiu em atividades que favoreceram que Ítalo Júlio andasse, corresse, coordenasse seus movimentos, tivesse mais equilíbrio, força e destreza manual. Estas atividades contribuíram para o progresso do aluno nestes aspectos como pudemos perceber na sua história no cotidiano escolar. A melhora de seu desenvolvimento motor ampliou as possibilidades dele agir sobre os objetos, de explorar o espaço e o tempo, de realizar as atividades propostas e de se relacionar com as pessoas no cotidiano escolar.

Érick melhorou alguns aspectos de seu desenvolvimento motor. Ele passou a movimentar mais seus braços e corpo, sua mão começou a abrir e fechar respondendo a sua intencionalidade da movimentação desta. Consideramos que a aplicação do botox que o aluno realizou com o objetivo de diminuir a espasticidade muscular foi um dos fatores que favoreceram esta aquisição motora. Mas, além deste fator, consideramos que o fato de o aluno ser incentivado constantemente a utilizar as partes do corpo que lhe eram possíveis para fazer tchau, pegar o giz de cera, enfiar o dedo na tinta, acariciar o cabelo da colega, tentar segurar a sua colher, esticar o corpo para facilitar que o colega trocasse seu babador, tentasse jogar o lixo no lixo, entre outras ações, certamente favoreceram o progresso no desenvolvimento motor. Além destes movimentos ativos que Érick era estimulado a realizar, a professora Marcela ou outro colega do aluno, fazia durante as atividades de leitura de revista, pintura, desenho em folha, alimentação (descascar a banana junto com o aluno, segurar sua mão para ele conhecer o movimento de levar a colher com o alimento até a boca), a movimentação passiva de seus membros e mão. A movimentação passiva é aquela que uma pessoa faz para movimentar uma parte do corpo de outra pessoa. Ela é fundamental para pessoas que não podem fazer o movimento por conta própria. Ao 
fazer este movimento, estamos oferecendo informações táteis e proprioceptivas ${ }^{48}$ para que a pessoa forme conexões neurais que permitam que seu cérebro conheça e interprete este movimento e os objetos manipulados. Lembramos que é através das sensações e da ação que descobrimos nosso próprio corpo, desenvolvemos nossa imagem corporal, estabelecemos nossas relações com as pessoas, com os espaços, com o tempo e com as atividades que fazem parte do nosso cotidiano. Quanto mais informações sensoriais recebermos, quanto mais estas formarem redes de conexões até o sistema nervoso central, mais possibilidades teremos de integrá-las e de gerar reações motoras e/ou desencadear processos cognitivos. Também, devemos considerar que o processamento das informações sensoriais para respostas motoras e/ou mentais, desencadeiam o mecanismo da plasticidade cerebral. Isto é, as células cerebrais que não têm uma função específica em nosso sistema nervoso podem passar a desempenhar determinada função na medida em que favorecermos continuamente o processo de formação de conexões neurais, através de estímulos sensorias, físicos e cognitivos.

Nos chamou a atenção o fato de que uma das expectativas com relação ao progresso do desenvolvimento e a aprendizagem era a de que Érick melhorasse o desenvolvimento motor. Num primeiro momento, podemos pensar que a limitação motora é algo que mobiliza a todos, pois explícita uma "paralisia", uma "não atividade". Características que dificilmente alguém gostaria de ter. Também é difícil para todos, perceber que embora tendo um "corpo que não se movimenta muito", há possibilidades de se ter "muito movimento mental". Normalmente, esperamos as respostas das pessoas com quem interagimos, por meio de seus movimentos ou de sua fala. Quando estamos diante de uma criança que inicialmente não se movimenta e/ou não fala, é fácil pensarmos o porque um dos objetivos iniciais do trabalho com o aluno ser a estimulação destes aspectos, como foi o que observamos tanto para o aluno Érick, quanto para o aluno Ítalo Júlio. Podemos pensar que este objetivo inicial é muito oportuno, embora não possamos nos limitar a ele. Isto é, para um aluno como o Érick, por exemplo, é importante que se ofereça atividades que favoreçam sua movimentação e sua comunicação constantemente. Entretanto, o aluno, mesmo

\footnotetext{
${ }^{48}$ Propriocepção significa: "sensibilidade própria aos ossos, músculos, tendões e articulações, que fornece informações sobre a estática, o equilíbrio, o deslocamento do corpo no espaço." (HOUAISS, 2001)
} 
tendo uma forma diferenciada de se movimentar e de se comunicar, pode e deve ser incentivado a desenvolver outros aspectos do seu desenvolvimento cognitivo, como felizmente aconteceu em seu cotidiano.

Nas histórias dos dois alunos podemos encontrar intervenções em favor do desenvolvimento de habilidades, competências e aprendizagens. Antes de exemplificarmos esta afirmação, são necessárias algumas considerações.

Entendemos que competências e habilidades estão relacionadas com desenvolvimento e aprendizagem. Todos estes quatro termos envolvem o processo de construção da inteligência. Esta se dá na interação contínua do sujeito com o meio. O primeiro objeto com o qual a criança interage e aprende a se relacionar é o objeto pessoa, sendo esta normalmente sua mãe. Concomitantemente a este aprendizado, seguem outros advindos das relações do sujeito com os outros objetos físicos do meio, espaço e tempo. Progressivamente, a criança tem que aprender a se relacionar com mais e mais pessoas do seu convívio cotidiano. Continuamente, também estará aprendendo a se relacionar com outros objetos, espaço e tempo. Assim sendo, se percebemos que uma criança se socializou, isto é, se adaptou ao convívio com outras pessoas e ao meio social em que está inserida, podemos dizer que ela progrediu no processo de construção da inteligência, que é, simultaneamente, um processo de construção de conhecimentos. Diante destas considerações, acrescentamos às proposições de Piaget (1957/1974) e Macedo (2003) os termos habilidades e competências, que juntamente com desenvolvimento e aprendizagem, são formas interdependentes de conhecimento.

Sustentados pelas afirmações de Piaget (1937/2001) de que a elaboração do universo pela criança é construída no seu relacionamento com os objetos (objetos pessoas e objetos físicos), espaço, tempo e nas relações de causalidade, compreendemos que os conhecimentos são construídos na relação que o sujeito (com suas características próprias) estabelece com as pessoas, com o espaço, com o tempo, com os objetos e com as atividades que realiza. Estas últimas mobilizam a relação com os demais elementos. Quando Érick estava realizando uma atividade de desenho, estava se relacionando com o próprio corpo, com o giz de cera, com o papel, com a mesa, com os colegas ou com a professora que coordenava a atividade e 
com as informações que esta atividade continha, quer sejam elas relacionadas às estórias, seu nome, números, cores, entre outras.

A vivência de situações cotidianas na escola deve ser considerada como um meio através do qual o conhecimento é construído na tessitura das complexas relações estabelecidas neste contexto. Numa visão construtivista, se consideramos conhecimento, conteúdos disciplinares, noções e conceitos desvinculados da vida cotidiana, não conseguiremos compreender a educação como um instrumento para a construção da autonomia e liberdade dos sujeitos, como propõe Piaget (1945/1998).

Baseados nas considerações acima, vamos dar alguns exemplos do que os alunos Érick e Ítalo Júlio aprenderam e desenvolveram.

Érick aprendeu a utilizar balbucios, sons, palavras, gestos e movimentos específicos para se referir a determinadas pessoas e/ou manifestar seus desejos e pensamentos. Portanto, ele desenvolveu habilidades comunicativas e se tornou progressivamente mais competente na atividade de se comunicar. Consideramos que alguns dos fatores que contribuíram para este progresso foram os fatos de as pessoas que com ele conviveram, terem permitido com que ele se expressasse da forma como lhe era possível, terem solicitado sua opinião em situações do cotidiano escolar e terem o desafiado para que ele elaborasse uma forma de demonstrar o que queria.

Érick aprendeu a se movimentar no espaço utilizando as formas que lhe eram possíveis em cada momento do seu cotidiano. Quando estava deitado no chão, aprendeu a movimentar o seu corpo para atingir o contato com aquele com quem queria. Quando estava no carrinho aprendeu a solicitar que os outros o levassem para o lugar desejado. Passou a pedir adaptações para melhorar o espaço em que seriam realizadas as atividades, como quando solicitava aos outros que colocassem sua tábua de apoio no carrinho. O fato dele se conhecer melhor, conhecer suas possibilidades e limitações da movimentação do seu corpo, conhecer os espaços de sua escola possibilitou que progredisse em suas habilidades de se movimentar no espaço e de utilizá-lo de acordo com suas necessidades. Foi se tornando mais competente para utilizar seus próprios recursos ou solicitar aos outros o auxílio para se relacionar no espaço. $\mathrm{O}$ fato dele ter circulado pelos vários espaços da escola de diversas maneiras contribuiu para este progresso. 
Érick desenvolveu a habilidade de manter a atenção nas atividades de rotina da escola, como era claramente percebido na brincadeira do pimpão. Isto favoreceu com que ele aprendesse a acompanhar o ritmo e a sequiência da música e a movimentar seu corpo da forma como lhe era possível na hora exata da sua vez. Portanto, Érick participava com competência desta atividade. $\mathrm{O}$ fato de esta atividade ser realizada com frequiência no cotidiano escolar, e Érick sempre participar dela, lhe proporcionou o desenvolvimento e a aprendizagem desta atividade.

Érick foi incentivado a sentir, tocar, manipular e conhecer os diversos objetos que faziam parte de seu cotidiano escolar. Assim, permitiu-se que ele deixasse de ter aversão à alguns dele (como era o caso da tinta e da boneca), e favoreceu a aprendizagem da função de cada um dos objetos com os quais se relacionava.

Érick aprendeu a brincar de faz-de-conta. No início do trabalho com o aluno na escola, ele não conseguia representar. Isto é, ele não conseguia passar do plano concreto para a representação de situações sem que elas de fato estivessem ocorrendo. A brincadeira de faz-de-conta era experimentada por Érick e os demais alunos no cotidiano da escola. Gradativamente ele foi assimilando e incorporando estas informações com a modificação de suas estruturas cognitivas para que tal progresso no seu desenvolvimento mental ocorresse.

Segundo a professora Marcela "o ponto culminante" do desenvolvimento de Érick foi a "sociabilidade". Como dissemos anteriormente, entendemos que o desenvolvimento da sociabilidade é fundamental dentro do processo de construção cognitiva, na medida em que implica o conhecimento de si mesmo, das habilidades necessárias para estabelecer relações com outras pessoas, da habilidade de se adaptar ao meio social no qual está inserida. Regina, mãe do aluno, achou que ele "aprendeu a pedir as coisas, aprendeu a se comunicar do jeito dele".

Marcela considerou que ele desenvolveu a possibilidade de ficar menos ansioso e se sentia mais seguro na escola. A segurança e a diminuição da ansiedade do aluno estão relacionadas ao fato dele se sentir e poder de fato estar inserido em um grupo que respeitasse suas singularidades e lhe possibilitasse se expressar, desenvolver e aprender de acordo com suas possibilidades. A segurança que a família passou a ter foi reflexo da disponibilidade e do investimento da escola em entender o aluno e lhe oferecer o melhor que podiam naquele momento diante de suas formações pessoais, 
profissionais, valores, atitudes e recursos materiais e estruturais da escola. A segurança da família deixou a escola e seus profissionais mais seguros que, conseqüentemente, ofereceram segurança ao aluno.

Sobre a fala de Marcela sobre sua impressão de que parecia que o aluno não tinha aprendido nada, uma vez que imaginava que ele ainda teria muito o que aprender, podemos dizer que ela tem razão em considerar que ele ainda tem muito o que aprender, uma vez que o processo de desenvolvimento e de aprendizagem se dá por toda a vida. Entretanto, por tudo o que relatamos na história deste aluno no cotidiano da escola podemos evidenciar progressos no seu desenvolvimento e aprendizagem em vários aspectos como já citamos anteriormente.

A resposta da professora sobre se as noções que ela havia contado que ele tinha desenvolvido não tinham sido aprendidas da escola -

[...] também, mas foi com o grupo. Eu não consigo ver assim: eu cheguei e mostrei para ele, foi através de uma atividade ... Foi através da interação com o grupo, com as dinâmicas. Deigles: Foi através das interações que ele foi aprendendo estes conceitos, estas noções? Isso. Eu acho que foi com o grupo e eu acho que é com o diário, a participação dele e a assiduidade que ele tem na escola, porque eu não consigo ver: Oh ... o Érick aprendeu a fazer o movimento lateral porque eu dei tinta para ele ... que foi naquele momento... não foi. Foi vivenciando o dia-a-dia, o cotidiano, e a rotina do dia-a-dia -

expressa a dimensão de interdependência, indissociabilidade e complementaridade nas relações para o aprendizado. Isto é, o desenvolvimento e a aprendizagem do aluno é conquistado com as múltiplas relações e vivências com as pessoas, objetos, espaço, tempo, atividades, com as experiências vividas no seu cotidiano. As experiências da escola, da casa, as relações e intervenções das pessoas que com ele conviveram, bem como as características individuais do aluno, são fatores que contribuíram para o seu desenvolvimento e a sua aprendizagem. Reafirmamos que toda vez em que falamos de experiências, consideramos que estas, necessariamente, têm que ser significativas para os sujeitos. Isto é, têm que ser experiências que provoquem o desejo no sujeito de realizá-las.

Consideramos que o desenvolvimento e o aprendizado de Ítalo Júlio, estão expressos nas palavras de sua professora, demais profissionais da escola e mãe.

Professora Yara achou que ele desenvolveu

a parte de coordenação e individualidade, fazer as coisas sozinho. Independência. Acho que ele desenvolveu bastante. Como estava no começo do ano e como está agora eu acho que teve um grande progresso, até na própria fala, que a gente não entendia nada e agora a gente entende. Não há necessidade de um ficar 
perguntando para o outro o que ele está falando. A gente consegue entender. Até nos próprios gestos, se locomover, descer e subir escadas. Jogar bola, que antes ele não jogava. Subir e descer escadas, ir ao escorregador que ele não fazia. Servir a merenda que no início do ano ele não fazia e agora já está fazendo, eu acho que ele progrediu bastante.

E, ele aprendeu

a se virar sozinho, a independência dele, ele consegue fazer muitas coisas sozinho. Porque aqui na escola ele não vai ter muito a ajuda do colega, que ele vai ter que fazer e em casa ele não faz. Tem coisa que ele faz aqui na escola que em casa ele não faz. Eu acho que ele já progrediu bastante.

Segundo os demais profissionais da escola

Eu percebi que ele desenvolveu bastante. Mesmo porque ele era assim dependente demais da mãe! [...] Ele era muito tímido, ele entrava na secretaria e ficava quietinho. Agora ele vai, ele mexe em alguma coisa que chama a atenção dele. Agora a gente vê que aos poucos ele foi desenvolvendo." (Marlene).

"Ele tinha timidez. Acabou a timidez, ele está mais comunicativo, hoje ele é participativo. Quer dizer, muito mais independente, dentro da dependência que ele tem ele se tornou bem mais independente! [...] Ele já está fazendo tudo sozinho, ele vai e se serve sozinho. Quando é uma coisa assim que a gente vê que está perigoso para ele a gente vai e dá uma mão, mas agora ele já vai para a mesa sozinho, vai para o banheiro sozinho. É um avanço, porque ele chegou aqui e dependia de tudo. Agora ele está subindo a escada, ele não precisa mais da gente para fazer isso.(Regiane).

Eu acho que ele está fazendo gracinha. Ele sabe que ele fazendo gracinha todo mundo vai em cima dele e assim fazer com que ele seja o centro da atenção. (Alessandra).

\section{Para sua mãe ele}

aprendeu bem a comunicação. A fala melhorou. Ir ao banheiro, que ele fazia direto xixi nas calças, não pedia. Agora ela falou que ele já tá pedindo né, ele vai. Em casa ele não pede, ele vai sozinho [...] ele começou a fazer em pé o xixi [...] o que eu acho legal, que as pessoas sabem que ele tá falando [...] saber também brincar com as outras pessoas, com as outras crianças... ele ficava só do lado, olhando brincar, não participava. Mesmo na outra escola, ele não participava mesmo das brincadeiras com as outras crianças. Apesar de ser pouquinhas crianças, seis crianças só na sala dele, ele não participava muito, o professor que as vezes trabalhava com ele contou essas coisas assim [...] ele tá mais assim na fala, que eu to percebendo [...] [ele está] pulando, pulava agora ele fica assim "mãe ó, ó.. ó mãe”, que ele ganha, até ele tá se divertindo, porque não tinha acho que a perna dele não dava para ele sustento. Ele pulava chegava muito perto do chão. São essas coisas que para as outras pessoas é besteira, mais para a gente é importante.

Ítalo Júlio aprendeu a realizar algumas atividades do cotidiano escolar utilizando os seus próprios recursos ou os utilizando para solicitar auxílio quando necessitava. Ele aprendeu a subir e descer escadas sozinho se apoiando no corrimão, aprendeu a subir as escadas do escorregador e a pedir ajuda para descer, aprendeu a correr atrás da bola e saber que tinha que chutá-la para fazer gol, a utilizar sua fala e gestos para ser compreendido por outros, a ir no banheiro sozinho, abaixar suas calças, fazer xixi 
em pé, ficar organizado na fila, reconhecer a rotina da escola, se servir e comer sozinho, reconhecer os objetos que lhe pertencia e pertencia aos outros, limpar a mesa quando a sujava (o que por sua vez contribuiu para que ele não a sujasse desnecessariamente), rosquear e desrosquear potes, montar com blocos tipo "montamonta", a brincar com massinha, a não molhar a roupa quando the solicitado com ênfase, brincar simbolicamente com o fantoche "Lolo", participar das brincadeiras com os colegas, compreender parcialmente as regras da brincadeira de escondeesconde, de corre-cotia e cabra-cega, aprendeu as noções de encima, embaixo, para um lado, para o outro, a reconhecer algumas cores, contar até cinco, se reconhecer no espelho, entre outros aprendizados. Ele progrediu no desenvolvimento de habilidades motoras, comunicativas, cognitivas e de cuidado próprio.

O desenvolvimento e a aprendizagem do aluno foram favorecidos pelas intervenções que lhe ofereceram possibilidades de utilizar os recursos motores e cognitivos já existentes naquela atividade com o objetivo de permitir com que ele a realizasse e assim obter um progresso. Os profissionais da escola colocavam regras que ele tinha que compreender e respeitar, tal como se posicionar na fila, esperar na porta até que a professora fosse chamar, não poder riscar a mesa, e se o fizesse teria que limpar. Eles ofereceram a possibilidade dele subir e descer as escadas várias vezes e de várias formas, sendo que em cada momento ele foi utilizando algumas adaptações para realizá-la de acordo com os seus recursos. Ítalo Júlio participava constantemente das brincadeiras da escola e as professoras intervinham quando necessário para aumentar ou diminuir as informações oferecidas em cada uma delas para proporcionar com que ele compreendesse o que estava acontecendo. Os profissionais conversavam com os alunos para que eles não privilegiassem o Ítalo Júlio nas atividades e não fizesse por ele aquilo que ele era capaz de fazer sozinho. Mesmo ainda não tendo manifestado o interesse por realizar atividades em folha de papel, esta era oferecida ao aluno para que ele compreendesse que ela poderia ser utilizada por ele com uma finalidade representativa ou outra que ele desejasse. Os profissionais faziam questões para que ele se reconhecesse e reconhecesse o grupo ao qual pertencia. Eles também solicitavam que ele ajudasse em pequenas tarefas do cotidiano, oferecendo as orientações e pistas necessárias para que ele as realizasse com êxito. 
Para exemplificarmos o que Piaget chamou de aprendizagem senso strito, podemos dizer que Ítalo Júlio aprendeu a subir e descer as escadas e em senso amplo, o que coincide com desenvolvimento, ele aprendeu a coordenar os movimentos dos seus membros em favor de um fim. Ele aprendeu a respeitar o seu lugar na fila e desenvolveu noções de organização espacial.

Durante o processo escolar de Ítalo Júlio podemos perceber que algumas das experiências pelas quais Ítalo Júlio passava não provocavam uma reação de resposta espontânea no aluno. Citamos as experiências na roda de conversa, em que ele só se manifestava quando uma pergunta direta era realizada a ele. Baseado nas proposições de Piaget (1974/1977) podemos inferir que estas experiências tiveram para o aluno um efeito negativo momentâneo, mas que poderá ser superado lentamente ou rapidamente. As perturbações que os assuntos e questionamentos da roda de conversa proporcionaram podem ser superados por uma acomodação compensadora. Isto é, seus esquemas poderão ser desenvolvidos para que ele possa compreender e se posicionar diante destes momentos, desde que, as possibilidades estruturais do desenvolvimento do aluno lhe permitam.

A professora Yara referiu que o aluno Ítalo Júlio "regrediu" depois das férias, depois do recesso do Seminário de Educação no Município e depois da mudança para a organização do espaço escolar em salas ambientes. A parada temporária na seqüência de um trabalho, como nos dois primeiros casos mencionados, pode demonstrar que para algumas pessoas, como Ítalo Júlio, realizarem determinados procedimentos são necessárias ações contínuas que lhes permitam colocar em movimento seus esquemas para que as atividades possam ser realizadas utilizando seus próprios recursos. $\mathrm{O}$ aluno demonstrou que sua estrutura de inteligência já lhe permitia compreender e realizar atividades como se servir e alimentar sozinho de forma mais independente. Quando esta atividade foi suspensa, e em seu lugar retomaram atitudes que não lhe permitia realizar no seu cotidiano esta atividade, ele não pode aprimorar seus esquemas. Por isso, atividades que deixaram de ser realizadas no cotidiano, constituíram para o aluno, um novo problema. Embora sua estrutura lhe permitisse, seus esquemas não estavam refinados o suficiente para garantir que ele não tivesse a defasagem em extensão descrita por Piaget (1937/2001) 
como um acontecimento possível no processo de desenvolvimento e aprendizagem das crianças.

Com relação à "regressão" observada nas atividades de localização espacial e temporal de Ítalo Júlio e de alguns outros colegas seus, podemos inferir que a mudança da organização do espaço físico e da seqüência das atividades da rotina da escola, trouxeram novos problemas tanto no plano da ação, quanto no plano da representação para os alunos. A nova organização da escola trouxe situações complexas. Simultaneamente, eles teriam a necessidade de representar e associar o conteúdo que seria desenvolvido em cada sala de aula, com o espaço e o tempo em que isto aconteceria e para onde e quando eles deveriam ir. Situações como esta podem desencadear nos alunos o que Piaget (1937/2001) chamou de defasagem em compreensão. Ítalo Júlio e outros alunos estavam diante de situações que exigiam que eles desenvolvessem no plano representacional conquistas anteriormente realizadas no período sensório-motor. Este tipo de defasagem também está prevista no desenvolvimento de todas as crianças.

Nesta pesquisa nos apoiamos nas constatações de Piaget (1936/1987), Piaget e Inhelder (1968/1999) e Inhelder (1943/1971) de que todas as pessoas seguem uma mesma seqüência evolutiva no desenvolvimento da inteligência - variando apenas em ritmo, de acordo com as peculiaridades das características individuais e das trocas estabelecidas com o meio externo.

Os estudos de Ide (1993) e Mantoan (1989, 1991, 2000), baseados em Inhelder (1943/1971) reafirmam a importância da solicitação do meio para o desenvolvimento das estruturas mentais e melhores condições de funcionamento intelectual. Os estudos das autoras citadas foram realizados com sujeitos com deficiência mental que em sua quase absoluta maioria eram alunos de escolas especiais.

O acompanhamento dos alunos Érick e Ítalo Júlio nos fazem formular a seguinte questão: será que estudar em um contexto educacional inclusivo que reconheça e invista nas possibilidades de desenvolvimento e aprendizagem de pessoas com deficiência, respeitando as suas peculiaridades, não podem promover um ambiente mais favorável à progressão dos níveis cognitivos dos alunos? Esta progressão se daria na medida em que as relações estabelecidas lhes proporcionem vivências que os coloquem em situações-problema para produzir perturbações e desencadear o 
funcionamento de seus esquemas para o conseqüente encadeamento do processo do desenvolvimento cognitivo. Isto é, se estudos realizados com alunos de escolas especiais já demonstraram o progresso no desenvolvimento e aprendizagem dos alunos, será que se acompanharmos os alunos com deficiência mental ou outras deficiências que estudarem em uma escola inclusiva não poderíamos esperar uma evolução a níveis cognitivos superiores aqueles encontrados nos estudos de Inhelder, Ide e Mantoan?

Esta pesquisa constata a possibilidade do progresso no desenvolvimento e aprendizagem de pessoas com deficiência nos aspectos sensoriais, cognitivos, motores, comunicativos, sociais e de independência tal como os estudos dos seguintes autores: Andretto (2001), Braccialli, Monteiro e Ravazzi (1998), Limongi (1992), Lorenzini (1999), Morato (1993) e Saad (2003).

Consideramos que o cotidiano escolar de Érick e de Ítalo Júlio possibilitou com que eles vivessem algumas das características da vida cotidiana propostas por Heller (1970/s.d.). Como todo homem eles tiveram o direito de freqüentar a escola e de participar das atividades cotidianas, sendo respeitada suas formas possíveis de participação. Assim, eles foram considerados como homens inteiros, com características peculiares e simultaneamente similares aos demais alunos. Eles viveram um cotidiano heterogêneo, diversificado pelas suas próprias características, dos profissionais de cada escola e de suas famílias. Cada uma das histórias dos alunos estavam sendo vividas num determinado contexto histórico, que também é peculiar para cada um, mas simultâneo no momento social. Cada um viveu a sua vida do indivíduo, de sujeito singular. Os profissionais e colegas que com eles conviveram, lhes possibilitaram fazer escolhas e serem espontâneos, ofereceram alternativas. Como todos os alunos, eles viveram um cotidiano de possibilidades e mimese.

Podemos perceber nas duas histórias o quanto o sutil, os pormenores das relações vividas no cotidiano dos alunos foram fundamentais para a compreensão da situação e consequentemente para o estabelecimento de propostas de intervenção que objetivassem o progresso do desenvolvimento e da aprendizagem dos alunos. Acreditamos que é na observação e na valorização constante destas relações sutis que podemos encontrar melhores formas de se trabalhar em um sistema complexo tal 
como uma educação inclusiva. As seguintes considerações da professora Marcela, expressam estas necessidades e possibilidades: “Eu aprendi a ouvir, observando [...] eu tive que observar além."

É no cotidiano escolar que os desafios de lidar com a heterogeneidade dos alunos são evidenciados, mas é também nele e na constante reflexão sobre ele, que podemos encontrar elementos que nos auxiliem a oferecer uma educação de qualidade a todos.

O instrumento que elaboramos nesta pesquisa para coleta de dados e intervenção em favor da melhor compreensão das necessidades dos alunos e, consequentemente, elaboração dos objetivos do trabalho com os alunos e termos parâmetros para a avaliação, foi de grande importância e cumpriu o seu objetivo. Se analisarmos as tabelas dos indícios do desenvolvimento e da aprendizagem dos alunos (Anexos $7 \mathrm{e}$ 8), observamos um crescente número de dados com o passar do tempo. Para nós isso se justifica por dois motivos principais. Primeiro porque no primeiro período as questões que o roteiro de observação propunha, não era foco de observação constante no cotidiano. Segundo, porque ao passar a ser, podemos perceber que as professoras e as escolas investiram no trabalho com os alunos explorando algumas das relações propostas no roteiro.

As histórias dos alunos no cotidiano escolar demonstraram que observar como, quando, por que e para que são estabelecidas as relações da criança no cotidiano na escola, expressaram o funcionamento do pensamento dos alunos e, consequentemente, os seus desenvolvimentos e suas aprendizagens.

$\mathrm{O}$ instrumento elaborado e as intervenções realizadas nesta pesquisa estiveram em favor de uma prática reflexiva (MACEDO 2002b). Uma vez que consideramos que ela é condição necessária para o desenvolvimento de uma prática inclusiva. $\mathrm{O}$ fato do instrumento ser baseado em questões que tinha como objetivo desencadear, no sentido de suscitar olhares e questionamentos para que os profissionais estivessem percebendo a singularidade e a perspectiva de cada criança, foi fundamental para o propósito da pesquisa e para "provocar" uma prática inclusiva.

Os profissionais das escolas e demais professores da rede municipal de educação de Mauá que conheceram o roteiro de observação explicitaram que não tinham o hábito de perceber e, portanto, valorizar as relações do cotidiano. Isto nos faz 
considerar que é comum querermos verificar resultados sem considerarmos o processo envolvido. Nossa experiência profissional, principalmente a formação em terapia ocupacional da pesquisadora, nos ensinou que tanto o processo quanto o produto expressam formas e possibilidades de fazer e conhecer o mundo. Além disso, se consideramos os alunos enquanto seres singulares, entendendo singularidade como o que é único, o que diferencia dos demais, acreditamos que só é possível trabalhar em um favor de uma educação inclusiva se examinarmos minuciosamente o aluno nas suas complexas e diversas relações cotidianas.

Após a realização desta pesquisa confirmamos nossa hipótese, pelos indícios favoráveis que o acompanhamento de Érick e Ítalo Júlio nas suas relações cotidianas nas suas escolas nos proporcionaram, de que relações cotidianas baseadas na lógica da inclusão, da interdependência, da indissociabilidade, da complementaridade, da singularidade do sujeito, da cooperação e da solidariedade, proporcionam o progresso no aprendizado de alunos com deficiência. É fundamental para tal, que todos os profissionais da educação, familiares e comunidade tenham confiança de que todos os alunos podem aprender independente do que, para que, como e quando lhes são oferecidos várias possibilidades de agir e construir os seus conhecimentos. Além disso, acreditamos que um cotidiano escolar inclusivo pode favorecer que alunos com deficiência realizem atividades por si mesmos e tomem decisões compatíveis as suas possibilidades o que suscita a construção da autonomia do sujeito. Um cotidiano escolar inclusivo deve colaborar para a constituição de um sujeito ativo e valorizado socialmente. Reforçamos que só acreditamos que um contexto regular de educação pode cumprir este objetivo quando entrar em contato de fato com os limites, mas sobretudo com as possibilidades das pessoas com deficiências.

Para que a escola e o sistema educacional como um todo, se organize em termos das relações e proposições acima, temos que estar dispostos a lidar com uma série de desafios, como estiveram os profissionais, famílias e alunos que participaram desta pesquisa.

Nas palavras de Tânia, dirigente da escola de Érick, encontramos exemplos desta disponibilidade e de alguns desafios vividos:

É possível conviver com indivíduos diferentes. É possível sim! Nós não estávamos acostumados. A escola não está preparada. Se a gente for parar para pensar a 
escola nunca vai estar preparada. Mas, quando vem e eles colocam essa criança, a gente de uma forma ou de outra vai ter que aprender a lidar com ela, com os erros, com os acertos, a gente está caminhando [...] é importante todo muito aceitar, não como aluno da Marcela ou da Suzi, mas como aluno da minha escola. A gente tem que tentar ajudar no que for preciso. O convívio vai ser diferente. É dificílimo, mas a gente aprende. A gente vê que eles são capazes de aprender. Ás vezes não no mesmo ritmo que a gente gostaria [...] acho que o lado positivo é esse de a gente ir em busca para tentar melhorar o nosso trabalho [...] até a pouco tempo a gente ficava pensando que se [o aluno com deficiência] conseguisse a socialização com o grupo já estava de bom tamanho, mas depois a gente vai vendo que não é somente isso. Então, eu acho que nos obriga a tentar alternativas para a gente estudar, melhorar a prática, a gente vai vivendo essa experiência, se não tivesse esses casos a gente estaria acomodado.

Conviver com a diversidade é algo que é possível como relata Tânia e constatamos nas nossas histórias. Entretanto, este convívio não foi historicamente oportunizado e incentivado nas práticas escolares e sociais. Por quantos e quantos anos estivemos afastados de pessoas com algum tipo de deficiência? Amaral (1995) lembra o destino dado às pessoas desviantes/diferentes/deficientes no universo grecoromano: "ora eram mortas, assim que percebidas como deficientes, ora eram simplesmente abandonadas à 'sua sorte', numa prática então eufemisticamente chamada de "exposição'." (p.43). Estamos no ano de 2003 e é somente nas últimas duas décadas que temos um movimento mundial mais explícito para que as pessoas com deficiência estejam incluídas nos espaços comuns da vida social, como a escola. Este fato faz com que tenhamos consciência que o convívio de forma harmônica e cooperativa com a diversidade não acontece em pouco tempo e, simplesmente, por implantações de leis. A dificuldade no convívio com a diversidade é, ao nosso ver, explicitada nas pessoas com deficiência por elas terem algum tipo de "marca", quer seja ela física, mental ou psíquica que evidencia a diferença. Mas, acreditamos que qualquer outra pessoa com alguma "diferença significativa" (AMARAL, 2002), também nos trás um certo desconforto. Segundo Crochik (1997, p.15),

[...] quanto maior a debilidade de experimentar e de refletir, maior a necessidade de nos defendermos daqueles que nos causam estranheza. E isso ocorre - e nunca é demasiado repetir - porque o estranho é demasiado familiar. Como Freud (1975) pôde mostrar, o medo frente ao desconhecido, ao diferente, é menos produto daquilo que não conhecemos, do que aquilo que não queremos e não podemos re-conhecer em nós mesmos através dos outros.

Com a leitura dos trabalhos de Adorno (1995), Ainscow, Porter e Wang (1997), Amaral (1995, 2002), Crochik (1997) Mrech (1999), podemos inferir que a autoreflexão é essencial para que tenhamos uma educação que respeite a diversidade de 
todas as pessoas. Ela favorece o reconhecimento e a tomada de consciência daquilo que nos assusta em nós mesmos e com que tenhamos que rever valores, atitudes, saberes cristalizados e preconceitos. Para Mrech (1999), esta revisão é fundamental para rompermos com as "estruturas de alienação no saber", com as práticas educativas que pretendem padronizar e tornar iguais os sujeitos, com a forma estereotipada de conceber o processo de ensino-aprendizagem e com as práticas que não consideram a singularidade do sujeito.

Para Macedo (em elaboração) “o respeito é um dos caminhos para se aprender a conviver com as diferenças e quem sabe preparar para uma inclusão no sentido verdadeiro do termo", isto é, "para uma cultura das diferenças".

A reflexão sobre a prática profissional é condição necessária para uma prática inclusiva como demonstram os estudos de Beraldo (1999), Buffa (2002), Castro (2002), Cordeiro (2003), Faleiros (2001), Medeiros (2002), Moraes (2002), Ross (2000), Souza (2002), Vizim (1997). Consideramos que a realização desta pesquisa e o instrumento de coleta de dados por nós utilizados, favoreceram aos profissionais das escolas, refletir sobre o trabalho cotidiano. Ter que observar as sutilezas das relações do aluno no cotidiano escolar, pensar sobre elas, discutir com os demais profissionais e com a pesquisadora, propiciou um processo reflexivo simultaneamente individual e coletivo aos envolvidos na pesquisa.

A prática reflexiva favorece que transformarmemos as "situações problemáticas" - aquelas que imobilizam as ações - em situações-problemas, para que os sujeitos mobilizem seus recursos e esquemas para tomadas de melhores decisões nos contextos em que se encontram (MACEDO, 1999).

Ao estarmos em contato com situações-problemas, com os desafios da diversidade, nossa prática profissional melhora, como está implícito na fala de Tânia. Não podemos nos contentar com aquilo que já conhecíamos, temos que estudar, temos que ser mais competentes para lidar com a multiplicidade de fatores presentes em um sistema complexo. Temos que agir na urgência e decidir na incerteza. Neste contexto, nos tornamos um profissional de melhor qualidade pois ele favorece o desenvolvimento de nossas competências afetivas e cognitivas. Consideramos que as professoras dos alunos, bem como os demais profissionais, também participaram de um processo que contribuiu para o desenvolvimento de suas competências e de suas 
habilidades. Valorizamos neste processo, a competência de compreender o processo de desenvolvimento e de aprendizagem dos alunos baseados na observação de suas relações no cotidiano escolar.

Para o desenvolvimento desta competência, os profissionais tiveram que falar e refletir sobre suas dúvidas, inseguranças e medos. Durante uma das entrevistas a professora Vanessa disse que algumas das dúvidas que tinha com relação ao desenvolvimento e a aprendizagem do aluno Érick e de outros com deficiência eram: até que ponto estes alunos poderiam ter um progresso? Qual era a capacidade deles? "Até que ponto a gente deve estar insistindo? Só mesmo no dia a dia que a gente vai saber?"

Acreditamos que neste trabalho encontramos indícios para responder à estes questionamentos. Vamos tentar evidenciá-los fazendo relações com alguns conceitos construtivistas. Um primeiro indício se refere a considerarmos como condições necessárias para o progresso do desenvolvimento e aprendizagem do aluno considerar a deficiência como um dos fatores que marcam algumas características mais ou menos constantes na estrutura biológica do aluno, porém, ela se manifestará de diferentes maneiras em cada aluno dependendo das alterações que ela suscitou e das relações com o meio que o aluno estabelecer ao longo da vida. Portanto, a singularidade do sujeito torna impossível determinar previamente até que ponto eles podem progredir. A capacidade deles pode ser verificada através da observação das relações no cotidiano. Estas são fontes de abertura para as possibilidades de desenvolvimento e de aprendizagem quando valorizadas as diversas formas do aluno se comunicar, compreender, pensar e agir. Assim sendo, percebemos que saber quais são as capacidades do aluno e até que ponto eles podem progredir se constituem em condições pseudonecessárias para o início do trabalho com o aluno. Consideramos que os profissionais envolvidos na pesquisa, perceberam ao longo do processo, que estes saberes não são de fato necessários de início, mas serão percebidos continuamente no decorrer do trabalho.

Apesar de nunca ter trabalhado com alunos com "necessidades educacionais especiais", Yara recorreu aos seus conhecimentos advindos da sua formação e prática profissional e os extrapolou na medida em que fez algumas inferências sobre o que seria mais adequado propor e/ou como agir com o aluno em determinados 
momentos. Ela e Marcela também recorreram à observação constante dos alunos nas suas relações com as pessoas, tempo, espaço, objetos e atividades no cotidiano escolar para inferir sobre as capacidades de desenvolvimento e de aprendizagem dos alunos. Assim, tanto Yara, quanto Marcela, criaram possibilidades de compreensão e atuação no contexto em que se encontravam.

Para finalizar esta discussão, gostaríamos de mencionar que a Secretaria Municipal de Educação, Cultura e Esportes de Mauá - SMECE, na época do período de coleta de dados, tinha apenas seis anos de processo em favor da construção de uma educação inclusiva. O sistema educacional neste município reflete que até poucos anos atrás, a educação inclusiva, a educação de qualidade a todos não era pensada e nem praticada. Nos últimos anos, este tema tem permeado o cotidiano das escolas. Porém, entendemos que ainda não podemos afirmar que estamos vivendo uma prática educacional inclusiva se considerarmos todos os seus princípios e fundamentos. Como indicam as pesquisas de Angelucci (2002), Prieto (1998, 2000) e Silva (2000) a política educacional dos sistemas de educação ainda não se traduzem de fato, em políticas inclusivas. Entretanto, acreditamos que ao irmos criando possibilidades dentro do sistema atual, podemos transformar e construir um novo sistema. Por isso, apesar dos inúmeros desafios, baseados nas histórias apresentadas neste trabalho, não acreditamos que uma educação inclusiva seja utopia, mas um sonho que se sonharmos juntos poderá se tornar realidade. 


\section{CONSIDERAÇÕES FINAIS}

A motivação para realizar esta pesquisa veio da prática profissional da pesquisadora em um sistema de educação que tinha como objetivo favorecer uma educação inclusiva. No acompanhamento deste processo, e das inúmeras questões que ele suscitava, surgiu a necessidade de estudar por que e quais as relações estabelecidas no cotidiano escolar podiam beneficiar o desenvolvimento e a aprendizagem de alunos com deficiência em uma perspectiva inclusiva de educação e evidenciar os progressos dos alunos neste contexto para termos dados que assegurasse e fortalecesse a construção da educação inclusiva no município.

Após este trabalho concluído, acreditamos que conseguimos trazer alguns elementos para responder as questões deste estudo. Falamos em alguns, porque consideramos que no processo de construção do conhecimento não temos respostas para todas as questões, mas sim, indícios que nos permitem ir a um ponto de melhor compreensão e deste formular novas questões.

Valorizamos e constamos neste estudo a importância das relações estabelecidas no cotidiano escolar para o processo de desenvolvimento e de aprendizagem de crianças com deficiência. Entretanto, não é qualquer tipo de relação que favorece este processo. Nas histórias dos alunos estudados percebemos a possibilidade de romper relações baseadas na lógica da exclusão e construir relações na lógica inclusiva, da interdependência.

A nossa prática profissional, as discussões e estudos realizados nas disciplinas da pós-graduação e esta pesquisa, mostram que ainda temos uma série de desafios. Mas, ao mesmo tempo, temos uma série de possibilidades para lidar com eles. Consideramos que as histórias dos alunos nos seus cotidianos escolares nos mostraram formas de agir na perspectiva da interdependência, de forma solidária, cooperativa e que favoreceram o desenvolvimento da autonomia de todos os envolvidos. Mostraram também, que estas formas de se relacionar não são fáceis, 
uma vez que estamos habituados a agir de forma dependente ou de forma independente ou de forma co-dependente.

O estudo evidenciou a necessidade de construção de instrumentos que auxiliem à compreensão das necessidades dos alunos, no processo de intervenção e avaliação em favor do progresso do aluno. Estes instrumentos têm como objetivo ampliar o olhar para a percepção das relações dos alunos no cotidiano escolar, sendo que estas são indícios do desenvolvimento e da aprendizagem do aluno. Além disto, eles contribuem para a reflexão sobre nossas ações e sobre elementos que auxiliem a compreender como e por que as pessoas aprendem.

Incentivar a competência coletiva foi uma das contribuições deste trabalho. Acreditamos que todos os envolvidos no processo educacional devem atuar na perspectiva da interdependência, indissociabilidade e complementariedade das ações e conhecimentos.

Realizar esta pesquisa confirmou que todas as pessoas podem aprender, que o conhecimento é um processo de construção assim como é a educação inclusiva. Esta só pode ser compreendida como um sistema complexo, em que estão implicados o todo e a parte simultaneamente. Isto é, o aluno, compreendido na sua singularidade é parte e todo ao mesmo tempo, assim como o contexto educacional e os envolvidos no processo educativo. Os fragmentos e indícios da realidade só podem ser compreendidos encadeadando uma situação vivida com outras. O que vivemos em uma educação inclusiva, tal como num sistema complexo, tem, como característica necessária, determinações multifatoriais interdependentes.

Chegou a hora de colocar um "ponto final" nesta dissertação! Esta é uma condição necessária para a conclusão do programa de pós-graduação e para a construção de um texto. A partir de agora, este texto passa a se constituir um todo, mas que em um outro momento ou contexto, poderá ser parte. O nosso desejo é que ele seja parte do processo de construção de uma educação inclusiva. Esperamos que as histórias de Érick e Ítalo Júlio nas suas relações no cotidiano escolar, tenham deixado "pistas" que auxiliem a todos neste processo.

O Prof. Dr. Lino de Macedo diz que para Piaget, o todo não existe, é uma abstração. O que existe é uma composição de partes. Portanto: 
Não vamos esperar ver o todo do sistema de educação como inclusivo. Vamos compor nas pequenas partes das relações no cotidiano, um raciocínio, um sentimento e uma prática inclusiva! 


\section{REFERÊNCIAS BIBLIOGRÁFICAS}

ADORNO, T. W. Educação Após Auschwitz. In: modelos críticos 2. Ed. Vozes. Petrópolis, 1995. p. 104-123.

Palavras e Sinais:

AINSCOW, M.; PORTER, G.; WANG, M. Caminhos para escolas inclusivas. Lisboa: Instituto de Inovação Cultural, 1997.

ALCUDIA, R. et al. Atenção à diversidade. Tradução de Daizy Vaz de Moraes. Porto Alegre: ARTMED, 2002.

ALLEGRETTI, A. L. C.; MANCINI, M. C.; SCHARTZMAN, J.S. Estudo do desempenho funcional de crianças com paralisia diparética espástica utilizando o pediátrica evaluation of disability inventory (PEDI). Temas sobre desenvolvimento, São Paulo, v. 11, n. 64, p.5 - 11, 2002.

AMARAL, L. A. A. Conhecendo a deficiência (em companhia de Hércules). São Paulo: Robe, 1995.

AMARAL, L. A. A. Diferenças, estigma e preconceito: o desafio da inclusão. In: KOHL, M. L., SOUZA, D. T. R., e REGO, T. C. (orgs.) Psicologia, educação e as temáticas da vida contemporânea. São Paulo: Moderna, 2002. p.233-248.

AMARO, D. G.; COUTO, S. C. Terapia ocupacional e a construção da educação inclusiva. In: CONGRESSO BRASILEIRO DE TERAPIA OCUPACIONAL, 6 ., 1999, Águas de Lindóia. Anais. Águas de Lindóia, 1999. 2 disquetes 3 1².

AMARO, D. G.; MACEDO, L. de. Da lógica da exclusão à lógica da inclusão: reflexão sobre uma estratégia de apoio à inclusão escolar. Educação on-line. Disponível em: <http://www.educacaoonline.pro.br/>. Acesso em: 13 de nov. 2002.

AMIRAliAn, M. L. T. et al. Conceituando deficiência. Revista de Saúde Pública, São Paulo, v. 34, n.1, p. 97 -103, fev. 2000.

ANDRÉ, M. (1989). A pesquisa no cotidiano escolar. In: FAZENDA, I. Metodologia da pesquisa educacional. 8. ed. São Paulo: Cortez, 2002. p.35-45.

ANDRÉ, M. A pedagogia das diferenças na sala de aula. 4.ed. Campinas: Papirus, 2002. 
ANDRETTO, Y. T. T. Os impactos da inclusão de criança deficiente no ensino regular: um estudo sobre a inclusão de criança com paralisia cerebral. 2001. 118f. Dissertação (Mestrado em Distúrbios do Desenvolvimento) - Coordenadoria de PósGraduação, Universidade Presbiteriana Mackenzie, São Paulo, 2001.

ANGELUCCI, C. B. Uma inclusão nada especial: apropriações da política de inclusão de pessoas com necessidades educacionais especiais na rede pública de educação fundamental do Estado de São Paulo. 2002. 171f. Dissertação (Mestrado em Psicologia Escolar e do Desenvolvimento Humano) - Instituto de Psicologia Escolar, Universidade de São Paulo, São Paulo. 2002.

ANNUNCIATO, N. F. Desenvolvimento do sistema nervoso: genes neurogênicos, fatores epigenéticos e hormônios. Temas sobre desenvolvimento, São Paulo, v. 9, n. 52, p. 40 - 41, set./out. 2000.

ARANHA, M. S. F. Interação social e o desenvolvimento de relações interpessoais do deficiente em ambiente integrado. 1991. 145f + anexos. Tese (Doutorado em Psicologia Experimental) - Instituto de Psicologia, Universidade de São Paulo, São Paulo. 1991.

ARANHA, M. S. F. Paradigmas da relação da sociedade com as pessoas com deficiência. Revista do Ministério Público do Trabalho, Brasília, ano XI, no 21 , p.160-173, março 2001.

BABEY, G.; MICHAEL, D. Terapia de integração sensorial A.J. Ayres. São Paulo, 1995. [Apostila].

BASTOS, M. B. Inclusão escolar: um trabalho com professores a partir de operadores da psicanálise. 2003. 125f. Dissertação (Mestrado em Psicologia Escolar e do Desenvolvimento Humano) -Instituto de Psicologia, Universidade de São Paulo, São Paulo. 2003.

BAUMEL, R. C, R. C.; SEMEGHINI, I. (orgs.). Integrar / incluir: desafio para a escola atual. São Paulo: FEUSP, 1998.

BASIL, C. Os alunos com paralisia cerebral: desenvolvimento e educação. In: COLL, C.; PALACIOS, J. E.; MARCHESI, A. (Orgs.). Desenvolvimento Psicológico e Educação. Tradução de Marcos A. G. Domingues. Porto Alegre: Artes Médicas, 1995. p.252-271.

BATTISTELLA, L. R.; BRITO, C. M. M. Classificação internacional de funcionalidade (CIF) international classification of functioning disability and health (ICF). Acta Fisiátrica, 9(2), 2002. p.98-101. Disponível em:

<http://www.saudeparavoce.com.br/telefisiatria/acta/Acta\%20Fisiatrica\%209(2)\%20 98-101.pdf >.Acesso em 23 de set. 2003. 
BENETTON, M. J. Terapia Ocupacional como instrumento nas ações de Saúde Mental. 1994. 190f. Tese (Doutorado em Saúde Mental) - Faculdade de Ciências Médicas, Universidade Estadual de Campinas, Campinas, 1994.

BENETTON, M. J. Terapia ocupacional e reabilitação psicossocial: uma relação possível? Revista de Terapia Ocupacional, Universidade de São Paulo, v. 4/7, p.53-58, 1996.

BENETTON, M. J. Trilhas associativas: ampliando recursos na clínica da psicose. 2 ed. São Paulo: CETO (Centro de Estudos de Terapia Ocupacional) Diagrama\&Texto, 1999.

BERALDO, P. B. As percepções dos professores de escola pública sobre a inserção do aluno tido como deficiente mental em classes regulares de ensino. 1999. 142f. Dissertação (Mestrado) - Universidade Federal de São Carlos, São Carlos. 1999.

BRACCIALLI, L.; MONTEIRO, P.; RAVAZZI, R. M. Q. Dança: influência no desenvolvimento da criança com paralisia cerebral. Temas sobre desenvolvimento, São Paulo, v. 7, n. 38, p.22-25, maio/junho 1998.

BRAGA, L. W. O desenvolvimento cognitivo na Paralisia Cerebral: um estudo exploratório. 1983.162f. Dissertação (Mestrado em Educação) - Faculdade de Educação, Departamento de teorias e fundamentos, Universidade de Brasília, Brasília, 1983.

BRASIL. Congresso Nacional. Constituição da república federativa do Brasil. 5 de outubro de 1988. Disponível em:

<http://www.camara.gov.br/Internet/cf/Constituicao.pdf>. Acesso em 15 de agosto. 2003.

BRASIL. Assembléia Legislativa do Estado de São Paulo. Constituição do estado de São Paulo. 5 de outubro de 1989. Disponível em:

<http://www.adusp.org.br/juris/default.htm>. Acesso em 19 de out. 2003.

BRASIL. Estatuto da Criança e do Adolescente. Lei no 8.069 , de 13 de julho de 1990. Disponível em: 〈http://www.unicef.org/brazil/eca01.htm〉. Acesso em 21 de out. 2003.

BRASIL. Congresso Nacional. Lei de Diretrizes e Bases da Educação Nacional. Lei $\mathrm{n}^{\circ}$ 9.394, de 20 de dezembro de 1996. Disponível em:

<http://www.educacaoonline.pro.br/>. Acesso em 19 de out. de 2003.

BRASIL. Congresso Nacional. Decreto no 3.298. 24 de outubro de 1999. Disponível em: <http://www.mec.gov.br/seesp/Ftp/legis/d3298.pdf>. Acesso em: 19 de out. 2003. 
BRASIL. Congresso Nacional. Plano nacional de educação. Lei no 10.172 de 09 de janeiro de 2001. Disponível em: 〈http://www.mec.gov.br/acs/pdf/pne.pdf >. Acesso em 19 de out. 2003.

BRASIL. Câmara de Educação Básica do Conselho Nacional de Educação.

Resolução CNE/CEB no 2. 11 de setembro de 2001. Disponível em:

<http://www.educacaoonline.pro.br/>. Acesso em 19 de out. 2003.

BRUNELLO, M. I. B. Ser lúdico: promovendo a qualidade de vida na infância com deficiência. 2001. 191f. Tese (Doutorado em Psicologia Escolar e do Desenvolvimento Humano) - Instituto de Psicologia, Universidade de São Paulo, São Paulo, 2001.

BUENO, J. G. Educação especial brasileira: integração/segregação do aluno diferente. 1 ed. SAO PAULO: EDUC - Editora da PUCSP, 1993.

BUENO, J. G. Educação inclusiva e escolarização dos surdos. Integração, Brasília, v.13, n.23, p.37 - 42, 2001.

BUENO, J. G. Crianças com necessidades educativas especiais, política educacional e a formação de professores: generalistas ou especialistas? Educação on-line.

Disponível em: <http://www.educacaoonline.pro.br/>. Acesso em 15 de agosto 2002.

BUFFA, M. J. M. B. A inclusão da criança deficiente auditiva no ensino regular: uma visão do professor de classe comum. 2002. 87f. Dissertação (Mestrado em Distúrbios da Comunicação Humana) - Hospital de Reabilitação de Anomalias Craniofaciais, Universidade de São Paulo, Bauru. 2002.

CAIADO, K. R. M. Lembranças da escola: histórias de vida de pessoas deficientes visuais. 2002. 209f. Tese (Doutorado em Didática) - Faculdade de Educação, Universidade de São Paulo, São Paulo. 2002.

CAPELLINI, V. L. M. F. A inclusão de alunos com necessidades educacionais especiais em classes comuns: avaliação do rendimento acadêmico. 2001. 222f. Dissertação (Mestrado) - Universidade Federal de São Carlos, São Carlos. 2001.

CARLO, M. R. do P. de. Se essa casa fosse nossa: instituições e processos de imaginação na educação especial. São Paulo: Plexus, 1999. p.7-32.

CARLO de M. M. R. P.; BARTALOTTI, C. C. (orgs.). Terapia Ocupacional no brasil. São Paulo: Plexus, 2001.

CARVALHO, M. A. Deficiência e cotidiano: reflexos e reflexões sobre a reabilitação. Revista de Terapia Ocupacional, Universidade de São Paulo, v.8, n. 2/3, p. 81-86, 1997. 
CARVALHO, L. M. G. As atividades lúdicas e a criança com paralisia cerebral: o jogo, o brinquedo e a brincadeira no cotidiano da criança e da família. 1998. 178f. Tese (Doutorado em Saúde Pública) - Faculdade de Saúde Pública, Universidade Estadual de Campinas, Campinas, 1998.

CARVALHO, R. E. A nova LDB e a educação especial. Rio de Janeiro: WVA, 1997.

CARVALHO, R. E. Temas em Educação Especial. Rio de Janeiro, WVA, 1998.

CARVALHO, R. E. Removendo barreiras para a aprendizagem. Porto Alegre: Mediação, 2000a.

CARVALHO, R. E. A organização da prática pedagógica na proposta inclusiva. Educação em debate: Educação e conhecimento. Mauá, ano 3, n.2, p. 26-32, 2000 b.

CASARIN, S. Reflexões sobre a integração social da pessoa deficiente. In: MANTOAN, M. T. E. A integração de pessoas com deficiência: contribuições para uma reflexão sobre o tema. São Paulo: Memnon: SENAC, 1997. p. 230-235.

CASTRO, E. D.; LIMA, E. M. F. A.; BRUNELLO, M. I. B. Atividades humanas e terapia ocupacional. In: CARLO de M. M. R. P.; BARTALOTTI, C. C. (orgs.).

Terapia Ocupacional no brasil. São Paulo: 2001. p. 41-59.

CASTRO, A. M. de. A prática pedagógica dos professores de ciências e a inclusão do aluno com deficiência visual na escola pública. 2002. 131f+anexos. Dissertação (Mestrado em Educação Especial) - Faculdade de Educação, Universidade de São Paulo, São Paulo. 2002.

CORDEIRO, C. A. da C. A educação inclusiva na perspectiva dos professores: a ponta do iceberg. 2003. 158f. Tese (Doutorado em Estado, Sociedade e Educação) Faculdade de Educação, Universidade de São Paulo, São Paulo. 2003.

CORIAT, J.; JERUSALINSK, A. El desarrollo temprano del nino mongólico. In: Cuadernos del desarrollo infantil. Buenos Aires: Centro Dra. Lidia Coriat, s.d. p. 4-10.

COSTA, M. L. G. da. Benefícios e entraves da inclusão escolar e social de crianças com dificuldades no processo de construção da linguagem. 2002. 335f. Tese (Doutorado em Psicologia da educação) - Faculdade de Educação, Universidade de São Paulo, São Paulo. 2002.

CROCHIK, J. L. Preconceito, indivíduo e cultura. São Paulo: Robe Editorial, 1997.

DAMIANI, A. M. N. A inclusão/integração de alunos deficientes no ensino regular: balanço tendencial da produção acadêmica sobre o tema. 2001. 84f. Dissertação (Mestrado) - Universidade Presbiteriana Mackenzie, São Paulo, 2001. 
DECHICHI, C. Transformando o ambiente da sala de aula em um contexto promotor do desenvolvimento do aluno deficiente mental. 2001. 245f. Tese (Doutorado) - Pontifícia Universidade Católica de São Paulo, São Paulo. 2001.

DOWNING, J. E. Including students with severe and multiple disabilities in typical classrooms. Baltimore: Paul H. Publishing Co., 1996.

DUARTE, G. M. Interação social entre uma criança portadora de deficiência auditiva e seus parceiros normais em ambiente natural de sala de aula: um estudo descritivo. 1990. 90f. Dissertação (Mestrado) - Universidade Federal de São Carlos, São Carlos. 1990.

EDUCAÇÃO ON-LINE. Disponível em: <http://www.educacaoonline.pro.br/> . Acesso em: 13 de nov. 2002.

FALEIROS, M. H. S. A inclusão de alunos com deficiência mental na perspectiva de suas professoras e produções acadêmicas. 2001. 112f. Dissertação (Mestrado) Universidade Federal de São Carlos, São Carlos. 2001.

FENILI, L. B. E.; SANT'ANNA, M. M. M. Vivendo o cotidiano. Revista do Centro de Estudos de Terapia Ocupacional, São Paulo, ano 6, n.6, p.22-24, out. 2001.

FERREIRA, J. R. A construção escolar da deficiência mental. 1989. 158f. Tese (Doutorado em Filosofia da Educação) - Faculdade de Educação, Universidade Estadual de Campinas, Campinas. 1989.

FERREIRA, I. C. N. O processo de construção da inteligência da pessoa portadora de deficiência mental. In: Caminhos do aprender. Brasília: Corde, 1993. p. 29-66.

FERREIRA, M. E. C. O enigma da inclusão: das intenções às práticas pedagógicas. 2002. 330f. Tese (Doutorado em Educação Especial). Faculdade de Educação, Universidade de São Paulo, São Paulo, 2002.

GARCIA, R. O conhecimento em construção - das formulações de Jean Piaget à teoria de sistemas complexos. Tradução de Valério Campos. Porto Alegre: Artmed, 2002. p. 15-69.

GARCIA, R. L. (org.). Método: pesquisa com o cotidiano. Rio de Janeiro: DP\&A, 2003.

GIDDENS, A. A transformação da intimidade. Tradução de Magda Lopes. 2. ed. São Paulo: Editora da UNESP, 1993. p. 99-123.

GINZBURG, C. Sinais - raízes de um paradigma indiciário. (1986). In: Mitos Emblemas e Sinais - Morfologia e história. Tradução de Federico Carotti. São Paulo: Companhia das letras, 1989. p. 143-180. 
GUIRADO, E. C. Inclusão escolar de uma criança com atraso no desenvolvimento neuropsicomotor: leitura piagetiana de um trabalho fisioterapêutico. 2001. 128f. Dissertação (Mestrado em Psicologia da Saúde) Universidade Metodista de São Paulo, São Bernardo do Campo. 2001.

GUYTON, A. C. Tratado de Fisiologia Médica. Tradução de Charles Alfred Esberard. 2. ed. em português traduzida da 6 ed. original. Rio de Janeiro: Interamericana, 1984.

HADJI, C. Avaliação desmistificada. Trad. Patrícia C. Ramos. Porto Alegre: Artmed, 2001. p. 9-25.

HELLER, A. Sociologia de la vida cotidiana. 2 ed. Barcelona: Península, 1987. p. 19-26.

HELLER, A. (1970). O cotidiano e a história. Tradução de Carlos Nelson Coutinho e Leandro Konder. 4 ed. São Paulo: Editora Paz e Terra, s.d. p. 17-63.

HEYMER, U.; GANEM, L. Observação de desempenho. São Paulo: Memnom, 1993.

HOUAISS. Instituto. Dicionário eletrônico da língua portuguesa. Versão 1.0 Copyright. Objetiva, 2001.

IDE, S. M. Itinerário de uma experiência: a construção do conhecimento de crianças deficientes mentais portadoras de síndrome de Down e suas interações no contexto escolar comum. 1993. 292f. Tese (Livre Docência) - Faculdade de Educação, Universidade de São Paulo, São Paulo. 1993.

INHELDER, B. (1943) El diagnostico del razonamiento en los debiles mentales. Tradução para a edição castelhana por Editoral Nova Terra. Barcelona: Nova Terra, 1971.

JORDÃO, M. C. M. A criança, a deficiência e a escola: uma intervenção orientada pela psicanálise. 2001. 225f. Dissertação (Mestrado em Psicologia Escolar e do Desenvolvimento Humano) - Instituto de Psicologia, Universidade de São Paulo, São Paulo. 2001.

KISHIMOTO, T. M. (Org.). Jogo, brinquedo, brincadeira e a educação. 3. ed. São Paulo: Cortez, 1999.

LA TAILlE, Y. de; OLIVEIRA, M. K.; DANTAS, H. Piaget, Vygotsky, Wallon: teorias psicogenéticas em discussão. São Paulo: Summus, 1992.

LIMA, E.S. Desenvolvimento e aprendizagem na escola: aspectos culturais, neurológicos e psicológicos. São Paulo: Série "Separatas"- GEDH, 1997. 
LIMONGI, S. C. O. Estudo sobre a relação entre o processo de cognição e a construção da linguagem em crianças portadoras de paralisia cerebral. 1992. 251f. Tese (Doutorado em Psicologia Social) - Instituto de Psicologia, Universidade de São Paulo, São Paulo, 1992.

LORENZINI, M. V. Brincando no ambiente natural: uma contribuição para o desenvolvimento sensório-motor da criança portadora de paralisia cerebral. 1999. 176f. Tese (Doutorado em Educação Física). Faculdade de Educação Física da Universidade Estadual de Campinas, Campinas, 1999.

LÜDKE, M.; ANDRÉ, M. E. D. A. Pesquisa em educação: abordagens qualitativas. São Paulo: EPU, 1986.

LUZ, A. O. C. Será que precisa aprender isso? Um estudo sobre as condições e possibilidades de abstração em jovens com deficiência mental. 1999. $125 \mathrm{f}$. Dissertação (Mestrado em Educação) - Faculdade de Educação, Universidade Estadual de Campinas, Campinas, 1999.

MACEDO, L. de. Sistemas simples e complexos: algumas considerações. Manuscrito não publicado. São Paulo: Instituto de Psicologia - USP, 1994a.

MACEDO, L. de. Ensaios Construtivistas. São Paulo: Casa do Psicólogo, 1994b.

MACEDO, L. de. Competência relacional e situação-problema: elementos para uma reflexão pedagógica. Manuscrito não publicado. São Paulo: Instituto de Psicologia, USP, 1999.

MACEDO, L. de. Prefácio. In: PERRENOUD, P. Ensinar: agir na urgência, decidir na incerteza: saberes e competências em uma profissão complexa. Tradução de Cláudia Schilling. 2. ed. Porto Alegre: Artmed, 2001a.

MACEDO, L. de. Fundamentos para uma educação inclusiva. Psicologia da Educação - Revista do Programa de Estudos Pós-Graduados (PUC/SP), São Paulo, v.13, p. $29-51,2001 b$.

MACEDO, L. de. A questão da Inteligência: todos podem aprender? In: KOHL, M. L., SOUZA, D. T. R., e REGO, T. C. (orgs.) Psicologia, educação e as temáticas da vida contemporânea. São Paulo: Moderna, 2002a. p.117-134.

MACEDO, L. de. Desafios à prática reflexiva na escola. Pátio: revista pedagógica, Porto Alegre, ano VI, n. 23, p.12-15, set./out. 2002b.

MACEDO, L. de. O lúdico nos processos do desenvolvimento e da aprendizagem escolar. Manuscrito não publicado. São Paulo: Instituto de Psicologia, Universidade de São Paulo, 2003.

MACEDO, L. de. Ensaios pedagógicos: como construir uma escola para todos? Porto Alegre: Artmed Editora. No prelo. 
MACHADO, N. J. Qualidade na educação: as armadilhas do óbvio. In: MANTOAN, M. T. E. (Org.). Pensando e fazendo educação de qualidade. São Paulo: Moderna, 2001. p. 13-50.

MACHADO, V. Repercussões da proposta "educação inclusiva" a partir do discurso de professores de educação especial da rede pública estadual paulista. 2003. 191f+anexos. Dissertação (Mestrado em Psicologia Escolar e Desenvolvimento Humano) -Instituto de Psicologia, Universidade de São Paulo, São Paulo. 2003.

MANTOAN, M. T. E. Compreendendo a deficiência mental - novos caminhos educacionais. São Paulo: Scipione, 1989.

MANTOAN, M. T. E. A solicitação do meio escolar e a construção das estruturas da inteligência no deficiente mental: uma interpretação fundamentada na teoria do conhecimento de Jean Piaget. 1991. 238f. Tese (Doutorado em Educação) Faculdade de Educação, Universidade Estadual de Campinas, Campinas, 1991.

MANTOAN, M. T. E. A integração de pessoas com deficiência: contribuições para uma reflexão sobre o tema. São Paulo: Memnon: SENAC, 1997.

MANTOAN, M. T. E. Educação de qualidade para todos: formando professores para a inclusão escolar. Temas sobre desenvolvimento, São Paulo, v.7, n.40, p.44-48, set./out.1998.

MANTOAN, M. T. E. Ser ou estar, eis a questão: explicando o déficit intelectual. 2.ed. Rio de Janeiro: WVA, 2000.

MANTOAN, M. T. E. Por uma escola (de qualidade) para todos. In: (Org.). Pensando e fazendo educação de qualidade. São Paulo: Moderna, 2001. p.51-70.

MATTOS, E. A. de. Contribuições do estudo e proposta para o processo de inclusão do aluno com necessidades educacionais especiais - deficiente mental na escola regular. 2000. 204-+anexos. Tese (Doutorado em História e Filosofia da Educação) - Faculdade de Educação, Universidade de São Paulo. 2000.

MAUÁ. Planejamento 1999. Mauá: Secretaria Municipal de Educação, 1999a. [Impresso].

MAUÁ. Avaliação das ações da equipe de apoio no $1^{\circ}$ semestre de 1999. Mauá: Departamento de Educação Especial do Município de Mauá, 1999b. [Digitado].

MAUÁ. Textos produzidos no departamento de educação especial de 1997 a 2001. Mauá: Departamento de Educação Especial do Município de Mauá, 2001a. [Digitado]. 
MAUÁ. Planejamento integrado educação, cultura, esportes e lazer 2001-2002. Mauá: Secretaria Municipal de Educação, Cultura, Esportes e Lazer, 2001 b.

[Digitado].

MAUÁ. Deficiências, distúrbios e/ou outras características e comportamentos típicos do desenvolvimento: considerações sobre fatores causais, características, comportamentos e informações relacionadas. Mauá: Escola Municipal de Educação Especial, 2002a. [Digitado].

MAUÁ. Políticas públicas de educação da cidade de Mauá. Mauá: Secretaria Municipal de Educação, Cultura, Esportes e Lazer, 2002b. [Digitado].

MAUÁ. Plano Municipal de Educação de Mauá: texto guia para discussão. Diário na Escola. Mauá: Secretaria Municipal de Educação, Cultura, Esportes e Conselho Municipal de Educação, 2003.

MAZZOTTA, M. J. S. Fundamentos de educação especial. São Paulo: Pioneira, 1982.

MAZZOTTA, M. J. S. Trabalho docente e formação de professores de educação especial. São Paulo: EPU, 1993.

MAZZOTTA, M. J. S. Educação especial no Brasil: história e políticas públicas. São Paulo: Cortez, 1996.

MELLO, M. B. Espaços, tempos da/na escola: o cotidiano e o transbordamento do racional. In: GARCIA, R. L. (org.). Método: pesquisa com o cotidiano. Rio de Janeiro: DP\&A, 2003. p.83-96.

MEDEIROS, W. A. Representações de professores sobre educação especial diante da inclusão escolar do aluno com necessidades educativas especiais na escola comum. 2002. 120f. Dissertação (Mestrado em Didática) - Faculdade de Educação, Universidade de São Paulo. 2002.

MENDES, E. G. Perspectivas para a construção da escola inclusiva no Brasil. In: PALHARES, M. S. e MARINS, S. C. (Orgs.). Escola inclusiva. São Carlos: EDUFSCAR, 2002. p.61-85.

MITTLER, P. Educação inclusiva: contextos sociais. Tradução de Windyz Brazão Ferreira. Porto Alegre: ARTMED, 2003.

MORAES, M. C. L. de. A capacidade diagnóstica do professor de educação infantil: um caminho para o conhecimento da terapia ocupacional. 2002. 117f. Tese (Doutorado em Saúde Materno-Infantil) - Faculdade de Saúde Pública, Universidade de São Paulo, São Paulo. 2002. 
MORATO, P. J. M. de P. Deficiência mental e aprendizagem: estudo dos efeitos de diferentes ambientes de aprendizagem na aquisição de conceitos espaciais em crianças com trissomia 21. Lisboa, 1993. 274p. Dissertação (Doutorado) - Faculdade de Motricidade Humana, Universidade Técnica de Lisboa. 1993.

MRECH, L. M. Educação inclusiva: realidade ou utopia? Educação on-line. Disponível em: <http://www.educacaoonline.pro.br/>. Acesso em: 13 de agosto de 2001.

MRECH, L. M. Psicanálise e Educação: novos operadores de leitura. São Paulo: Editora Pioneira Educação, 1999.

NEUROLOGY CHANNEL. Botulinum toxin Therapy.

Dados disponíveis em: 〈http://www.neurologychannel.com/botulinum/index.shtml >. Acesso realizado em 27 de out. 2003.

NUNES, L. R. D'O. de P. et al. Pesquisa em educação especial. Rio de Janeiro: SETTE LETRAS, 1998.

ODEH, M. M. Família e escola na socialização e formação da identidade da criança com deficiência: formas de resistência e estratégias de adaptação. 1998. 289f. Tese (Doutorado) - Universidade Federal de São Carlos, São Carlos. 1998.

OLIVEIRA, V. B. de. O símbolo e o brinquedo: a representação da vida. 2. ed. Petrópolis: Vozes, 1998.

OLIVEIRA, V. M. O jogo no contexto da educação física como estratégia de intervenção pedagógica para a pessoa deficiente mental. 2000. 138f. Dissertação (Mestrado em Educação Física) - Faculdade de Educação Física, Universidade Estadual de Campinas, Campinas, 2000.

PAGANIZZI, L. Acerca le las actividades cotidianas. Revista do Centro de Estudos de Terapia Ocupacional - C.E.T.O., São Paulo, ano 7, n.7, p.22-24, dez. 2002.

PÁTIO: REVISTA PEDAGÓGICA. Porto Alegre, ano V, n. 20, fev./abril 2002.

PERRENOUD, P. Pedagogia diferenciada: das intenções à ação. Tradução de Patrícia Chittoni Ramos. Porto Alegre: Artmed, 2000a.

PERRENOUD, P. 10 novas competências para ensinar. Tradução de Patrícia Chittoni Ramos. Porto Alegre: Artmed, 2000b.

PERRENOUD, P. Os desafios da avaliação no contexto dos ciclos de aprendizagem plurianuais. In: PERRENOUD, P. et al. As competências para ensinar no século XXI: a formação dos professores e o desafio da avaliação. Tradução de Cláudia Schilling e Fátima Murad. Porto Alegre: Artmed, 2002. 
PESSOTTI, I. Deficiência mental: da superstição à ciência. São Paulo: EDUSP, 1984.

PFEIFER, L. I. Comprometimento motor e aquisição de habilidades cognitivas em crianças portadoras de paralisia cerebral. Temas sobre desenvolvimento, São Paulo, ano 6, n. 31, p.4 - 14, março/abril 1997.

PIAGET, J. (1932). O juízo moral na criança. Tradução de Elzon Lenardon. São Paulo: Summus, 1994.

PIAGET, J. (1936). O nascimento da inteligência na criança. Tradução de Álvaro Cabral. Rio de Janeiro: Guanabara, 1987.

PIAGET, J.(1937). A construção do real na criança. Tradução de Ramon Américo Vasques. São Paulo, Ática: 2001.

PIAGET, J. (1945). A representação do mundo na criança. Tradução de Rubens Fiúza. Rio de Janeiro: Record, s.d. p. 5-28.

PIAGET, J. (1945). A educação da liberdade. In: PARRAT, S. e TRYPHON, A. (Org.). Jean Piaget Sobre a Pedagogia: textos Inéditos. Tradução de Claudia Berliner. São Paulo: Casa do Psicólogo, 1998.

PIAGET, J. (1957). Aprendizagem e conhecimento. Traduzido pela Equipe da Livraria Freire Bastos. Rio de Janeiro: Livraria Freitas Bastos, 1974. p.33-91.

PIAGET, J. (1976). O possível, o impossível e o necessário. In: LEITE, L. B. (Org.) e MEDEIROS, A. A. (Col.). Piaget e a escola de genebra. São Paulo: Cortez, 1987. p.51-71.

PIAGET, J. (1967). Biologia e Conhecimento: ensaio sobre as relações entre as regulações orgânicas e os processos cognoscitivos. Tradução de Francisco M. Guimarães. 3. Ed. Petrópolis: Vozes, 2000. p. 221-225.

PIAGET, J.(1981). O possível e o necessário. Vl. 1. Tradução de Bernardina Machado de Albuquerque. Porto Alegre: Artes Médicas, 1985. p. 29-50.

PIAGET, J. Prefácio. In: INHELDER, B.; BOVET, M.; SINCLAIR, H. (1974). Aprendizagem e estruturas do conhecimento. Tradução de Maria Aparecida Rodrigues Cintra e Maria Yolanda Rodrigues Cintra. São Paulo: Editora Saraiva, 1977. p.7-12.

PIAGET, J.; INHELDER, B. (1968). A psicologia da criança. Tradução de Octavio Mendes Cajado. Rio de Janeiro: Bertrand Brasil, 1999. 
PICCHI, M. B. Da integração desejável à possível do portador de deficiência mental na classe comum da rede de ensino do estado de São Paulo. 1999. 136f. Tese (Doutorado em Didática) - Faculdade de Educação, Universidade de São Paulo, São Paulo. 1999.

PRIETO, R. G. Educação escolar para todos: um direito conquistado e não garantido. In: BAUMEL, R. C, R. C.; SEMEGHINI, I. (orgs.). Integrar / incluir: desafio para a escola atual. São Paulo: FEUSP, 1998. p.129 - 148.

PRIETO, R. G. Política educacional do município de São Paulo: estudo sobre o atendimento de alunos com necessidades educacionais especiais, no período de 1986 a 1996. 2000. 260f. Tese (Doutorado em Estado, Sociedade e Educação) - Faculdade de Educação, Universidade de São Paulo, São Paulo. 2000.

PRIETO, R. G. A construção de políticas públicas de educação para todos. In: PALHARES, M. S. e MARINS, S. C. (Orgs.). Escola inclusiva. São Carlos: EDUFSCAR, 2002. p.45-59.

PUESCHEL, S. M. Síndrome de Down: guia para os pais e educadores. Tradução de Lúcia Helena Reily. Campinas: Papirus, 1993.

RAMALHO, C. M. J.; PEDROMÔNICO, M. R.; PERISSINOTO, J. Síndrome de Down: avaliação do desempenho motor, coordenação e linguagem (entre dois e conco anos). Temas sobre desenvolvimento, São Paulo, v. 9, n. 52, p.11-14, set./out. 2000.

ROSS, P. R. Educação e exclusão: um projeto de cidadania das pessoas com necessidades especiais. 2000. 387f. Tese (Doutorado em Didática)- Faculdade de Educação, Universidade de São Paulo, São Paulo. 2000.

SAAD, S. N. Preparando o caminho da inclusão: dissolvendo mitos e preconceitos em relação à pessoa com síndrome de Down. 2002. 277f. Dissertação (Mestrado em Didática) - Faculdade de Educação, Universidade de São Paulo, São Paulo. 2002.

SACALOSKI, M. Inserção do aluno D.A. no ensino regular: a comparação entre o desempenho dos alunos ouvintes e D. A. e a visão dos pais, professores e alunos. 2002. 192f. Tese (Doutorado em Ciências dos Distúrbios da Comunicação Humana campo fonioaudiológico) - UNIFESP - EPM, 2002.

SALA, E. Em busca da cidadania ativa de pessoas acometidas por paralisia cerebral: a contribuição da escola. 2003. 154f. Tese (Doutorado em Estado, Sociedade e Educação) - Faculdade de Educação, Universidade de São Paulo, São Paulo. 2003.

SANT’ANNA, M.M.M. Educação inclusiva e inclusão social: a clínica da terapia ocupacioanal. Temas sobre desenvolvimento, São Paulo, v.11, n.61, p.10-15, 2002. 
SATO, L.; SOUZA, M. P. R. Contribuindo para desvelar a complexidade do cotidiano através da pesquisa etnográfica em psicologia. Psicologia USP, São Paulo, v. 12, n.2, 2001.

SANTOS, M. P. Educação inclusiva e a declaração de salamanca: conseqüências ao sistema educacional brasileiro. Revista integração, ano 10, n.22, 2000.

SANTOS, M. T. da C. T. dos. O regular da escola regular: desafios na/da construção de uma escola para todos. 2002. 190f. Tese (Doutorado) - Faculdade de Educação, Universidade Estadual de Campinas. 2002.

SASSAKI, R. K. Inclusão: Construindo uma Sociedade para Todos. Rio de Janeiro, WVA: 1997.

SCHWARTZMAN, J. S. Paralisia Cerebral. Temas sobre desenvolvimento, São Paulo, ano I, n.6, p.3-5, maio/jun.1992.

SCHWARTZMAN, J. S. e col. Síndrome de Down. São Paulo: Memnon: Mackenzie, 1999.

SEKKEL, M. C. A construção de um ambiente inclusivo na educação infantil: relato e reflexão sobre uma experiência. 2003. 203f. Tese (Doutorado em Psicologia Escolar e Desenvolvimento Humano) - Instituto de Psicologia, Universidade de São Paulo, São Paulo. 2003.

SILVA, R. K. A neuroplasticidade no desenvolvimento de crianças com paralisia cerebral. Temas sobre desenvolvimento, São Paulo, v.9, n.53, p.62-69, nov./dez.2000.

SILVA, S. Educação especial: um esboço de política pública. 2000. 183f. Tese (Doutorado em Estado, Sociedade e Educação) - Faculdade de Educação, Universidade de São Paulo, São Paulo. 2000.

SOUZA, A. M. C. Prognóstico funcional da paralisia cerebral. In: SOUZA, A. M. C. e FERRARETTO, I. Paralisia cerebral: aspectos práticos. 2 ed. São Paulo: Memnon, 1998. p. 33-37.

SOUZA, N. F. de. A prática pedagógica e as implicações na construção do conhecimento dos alunos com baixa visão: ensino regular. 2002. 140f. Dissertação (Mestrado em Educação Especial) - Faculdade de Educação, Universidade de São Paulo, São Paulo. 2002.

STAINBACK, S.; SATAINBACK, W. (1996). Inclusão: um guia para educadores. Tradução Magda França Lopes. Porto Alegre: Arte Médica Sul, 1999. p. 21-66.

STOBAUS, C. D. e MOSQUERA, J. J. M. Educação Especial: em direção à educação inclusiva. Porto Alegre: EDIPUCRS, 2003. 
TAKATORI, M. O brincar no cotidiano da criança com deficiência física: privilegiando um olhar para a construção das intervenções em reabilitação. 1999. 232p. Dissertação (Mestrado em Psicologia Escolar e do Desenvolvimento Humano). Instituto de Psicologia, Universidade de São Paulo, São Paulo, 1999.

TAKATORI, M. O brincar no cotidiano da criança com deficiência física: reflexões sobre a clínica da terapia ocupacional. São Paulo: Atheneu, 2003.

TEDESCO, J. C. Paradigmas do cotidiano: introdução à constituição de um campo de análise social. Santa Cruz do Sul: EDUNISC, 1999. p. 7-35.

TORRES, M. Z. T. Processos de desenvolvimento e aprendizagem de adolescentes em oficinas de jogos. 2001. 273f. Tese (Doutorado em Psicologia Escolar e do Desenvolvimento Humano) - Instituto de Psicologia, Universidade de São Paulo, São Paulo. 2001.

UNESCO - ORGANIZAÇÃO DAS NAÇÕES UNIDAS PARA A EDUCAÇÃO, A CIEÊNCIA E A CULTURA. Declaração de Salamanca: sobre princípios, política e prática em educação especial. 10 de junho de 1994. Disponível em:

<http://www.educacaoonline.pro.br/>. Acesso em 19 de out. 2003.

UNIVERSIDADE DE SÃO PAULO. Instituto de Psicologia. Serviço de Biblioteca e Documentação. Normalização de referências bibliográficas (ABNT). Disponível em:

<http://www.usp.br/ip/biblioteca/pdf/NormalizacaodeReferenciasABNT.pdf>. Acesso em: 12 de out. 2002.

UNIVERSIDADE DE SÃO PAULO. Instituto de Psicologia. Serviço de Biblioteca e Documentação. Citações no texto e notas de rodapé: manual de orientação (ABNT). Disponível em:

<http://www.usp.br/ip/biblioteca/pdf/CitacoesnotextoABNT.pdf >. Acesso em: $12 \mathrm{de}$ out. 2003.

UNIVERSIDADE DE SÃO PAULO. Instituto de Psicologia. Serviço de Biblioteca e Documentação. Diretrizes para a elaboração de dissertações e teses. Disponível em:

<http://www.usp.br/ip/biblioteca/pdf/Dissertacoeseteses.pdf >. Acesso em: 12 de out. 2003.

VINHA, T. P. O educador e a moralidade infantil: uma visão construtivista. São Paulo: Mercado das Letras - Fapesp, 2000. p. 157-158.

VIZIM, M. Representações da deficiência no cotidiano escolar e suas implicações nas práticas pedagógicas. 1997. 164f. Dissertação (Mestrado em Didática) Faculdade de Educação, Universidade de São Paulo, São Paulo. 1997. 
WATANABE, M. I. A. Educação inclusiva: realidade ou utopia? 2002. 110f. Dissertação (Mestrado em Distúrbios do Desenvolvimento) - Universidade Presbiteriana Mackenzie, São Paulo. 2002.

WCEFA. Declaração Mundial sobre Educação para Todos. 5 a 9 de março de 1990. Traduzida do original em inglês. Disponível em:

<http://www.educacaoonline.pro.br/>. Acesso em 19 de out. 2003.

WERNECK, Claudia. Ninguém mais vai ser bonzinho na sociedade inclusiva. Rio de Janeiro: WVA, 1997.

WERNECK, Claudia. Sociedade inclusiva: quem cabe no seu todos? Rio de Janeiro, W.V.A., 1999.

WISE, L.; GLASS, C. Trabalhando com Hannah: uma criança especial em uma escola comum. Tradução de Ronaldo Cataldo Costa. Porto Alegre: Artmed, 2003.

YAZLLE, C. H. D. Pré-escolas convivendo com a paralisia cerebral: uma análise do processo de inclusão/exclusão. 2001.177f. Dissertação (Mestrado em Saúde Mental) - Faculdade de Medicina de Ribeirão Preto, Universidade de São Paulo, Ribeirão Preto. 2001. 
ROTEIRO DE OBSERVAÇÃO DO ALUNO NO COTIDIANO DA ESCOLA 


\section{Roteiro de observação do aluno no cotidiano da escola}

\section{Relação com pessoas}

a. O aluno interage com as pessoas da comunidade escolar (professores, alunos, pais de alunos, merendeira, vigia, auxiliar administrativo, serviço geral, diretor)? Como estabelece esta interação? Comunicando-se através de gestos ou outros movimentos corporais (apontando, sorrindo, chorando, piscando) falando, ou de outras formas? Em quais momentos interage? Em quaisquer momentos, só quando precisa de ajuda, na merenda, quando quer ir ao banheiro, ou outros?

b. O aluno sabe quem é seu professor? Como demonstra isso?

c. O aluno sabe quem são seus colegas de classe? Como demonstra isso?

d. O aluno sabe quem são os outros professores e funcionários da escola, tais como merendeira, vigia, auxiliar administrativo, servente geral, diretor? Como demonstra isso?

e. Quem são as pessoas de referência do aluno na escola (professor, colegas ou outros funcionários)? Qual ação, comportamento, atitude do aluno você considera que demonstra isso?

f. Como o aluno reage e responde ao contato e solicitação dos outros (professor, funcionários, colegas, etc.)?

g. O aluno fica atento ao que o outro fala? Espera o outro parar de falar para manifestar seu desejo de comunicação? Entende regras de convívio da escola, como pedir licença para as pessoas, não gritar com o outro, não xingar, não beliscar, não bater, não arrancar o objeto (brinquedo, lápis, papel, colher, prato, etc.) da mão do outro? Como demonstra isso?

h. Como é a relação do aluno consigo mesmo? Isto é, como ele se relaciona com o próprio corpo, desejos e sentimentos? Como ele manifesta estes últimos?

i. Como o aluno usa o corpo no cotidiano da escola? Para quê ele usa? Em que situações?

j. Ele reconhece suas partes do corpo e sabe a função de cada uma? Como demonstra isso? Ele sabe escovar os dentes, abaixar suas calças, se limpar, se vestir sem o auxílio do outro? Se ele precisa de auxílio, que tipo de auxílio é este?

\section{Relações com espaço}

a. O aluno sabe onde é sua sala de aula, banheiro, cozinha, refeitório, parque, sala da diretora, e outros locais da escola? Como demonstra isso (se dirige até estes sem que alguém o oriente, aponta para eles quando solicitado ou espontaneamente, sabe orientar as pessoas sobre a localização de tais locais)?

b. Como o aluno se locomove nos espaços da escola? Andando, correndo, em cadeira de roda, com andador, se apoiando nos móveis e paredes, no colo de outra pessoa? Precisa que alguém o acompanhe? Por quê?

c. Em sua sala de aula ele sabe onde é o lugar que normalmente senta? Onde é o lugar de guardar sua mochila, os brinquedos, os materiais escolares etc.? Como demonstra isso? 


\section{Roteiro de observação do aluno no cotidiano da escola}

\section{Relações com tempo}

a. O aluno realiza as tarefas no tempo planejado para sua execução (das atividades em sala de aula, na merenda, no banheiro, no parque etc)? Ele as termina muito rápido, muito lento? Espera os outros para dar continuidade ao que estava sendo realizado ou a novas tarefas? Espera sua vez na realização das atividades?

b. Demonstra reconhecer a rotina das atividades na escola pelo horário ou seqüência das atividades? Sabe que quando chega é a hora da roda da conversa, depois é o parque, depois é a merenda, etc.? Como demonstra isso?

c. Como e quando o aluno se movimenta na sala de aula, na escola?

\section{Relações com objetos}

a. O aluno sabe o que é seu, o que é do outro e o que é da escola? Como demonstra isso?

b. Ele cuida dos objetos que fazem parte do cotidiano na escola? Como? Em que situações?

c. Ele atribui e usa os objetos a partir de sua função (usa o lápis para escrever, desenhar, a colher para comer, o livro para ler etc.)? Como você percebe isso? Em que situações?

d. Como ele manuseia os objetos (como ele abre a porta, a pia, abre a caixa dos brinquedos, segura a tesoura etc)? Ele precisa de alguma adaptação para estes manuseios? Por quê? Em que situações?

e. Quais são os brinquedos de preferência do aluno? Como você identifica isso?

\section{Relação com atividades}

a. O aluno demonstra compreender as tarefas a serem realizadas no cotidiano da escola? Quais? Em que situações? Como demonstra isso? Que recursos são necessários utilizar para que ele compreenda?

b. O aluno realiza as atividades do cotidiano da escola? Quais? Em que situações? Como o faz? Precisa de ajuda? Que tipo de ajuda? Precisa de adaptações para realizá-las (de conteúdo, da forma, do tempo, dos objetos)?

c. Como o aluno brinca? Em que situações ele estrutura brincadeiras? Como você percebe isso?

d. Ele prefere brincar sozinho, com os colegas ou com o professor? Em que brincadeiras e atividades ele solicita a participação de outro? Por quê? Quais atividades ele gosta? Quais atividades ele não gosta? Quais atividades ele rejeita? 
ANEXO 2

ROTEIRO DE OBSERVAÇÃO DO ALUNO NO COTIDIANO EM CASA 


\begin{tabular}{|l|l|}
\hline ALUNO: & D.N.: \\
\hline ESCOLA: & \\
\hline PROFESSORA: & \\
\hline MÃE: & \\
\hline PAI:
\end{tabular}

Entrevista realizada em:

$\Rightarrow$ O que você espera que seu filho desenvolva / aprenda na escola?

\section{1) Relação com pessoas}

a. Como o seu filho se comunica com você, com seu marido, com o pai, irmãos, avôs, parentes e amigos? Comunica-se através de gestos ou outros movimentos com o corpo (apontando, sorrindo, chorando, piscando, olhando) falando ou que outro jeito? Em que momentos ele se comunica? Em quaisquer momentos, só quando precisa de ajuda para fazer alguma coisa que quer, quando quer contar alguma coisa, quando quer pedir alguma coisa, quando não quer aceitar o que vocês estão pedindo para ele fazer, ou em que outros momentos?

b. Ele sabe quem é sua mãe, pai, avós, irmãos, amigos, parentes, etc.? Como demonstra isso?

c. Quem são as pessoas que ele mais gosta da sua família ou amigos? Por quê você acha isso?

d. Como ele reage quando vocês solicitam a atenção dele ou pedem para ele fazer alguma coisa?

e. Que coisas que vocês falam para ele e que acontecem na rotina do dia-a-dia, que vocês acham que ele compreende? Ele entende as regras da casa de vocês e as respeitam? Por quê vocês acham isso?

f. Ele reconhece as suas partes do corpo? Como e quando você percebe isso? Como e para quê ele usa o corpo dele no dia-a-dia em casa?

g. Ele mostra para vocês quando ele está triste, alegre, com dor, insatisfeito, querendo alguma coisa? Como ele mostra isso?

h. Quando de frente ao espelho, ele sabe que a imagem refletida é dele? Como você percebe isso?

i. O que chama atenção de vocês ou vocês acham curioso no jeito dele se relacionar com as pessoas?

\section{2) Relação com espaço}

a. Como ele se locomove em casa? Andando, engatinhando, apoiando nos móveis, se arrastando, num carrinho ou cadeira de rodas, com um andador? Que tipo de auxílio ele precisa para se locomover? Por quê? Quando e por quê ele se locomove / movimenta em casa?

b. Ele sabe onde é o quarto dele, o lugar onde ele dorme, onde é o banheiro, a cozinha? Quando vocês estão chegando perto da sua casa ele sabe qual casa é 


\section{Roteiro de observação do aluno no cotidiano em casa}

a dele? Como ele demostra isso (se dirige até estes sem que alguém o oriente, aponta para eles quando solicitado ou espontaneamente, sabe orientar as pessoas sobre a localização de tais locais)?

c. Ele sabe onde fica guardadas as coisas que ele usa e quer no dia-a-dia? Como ele demonstra isso? Ele guarda as coisas que ele pega? Quando e por quê?

\section{3) Relação com tempo}

a. Ele demonstra reconhecer a rotina das atividades do dia-a-dia em casa pelo horário ou pela sequiência das atividades? Sabe que quando acorda é hora de tomar café, depois ir ao banheiro, tomar banho, ir para escola, quando já é de tarde, noite, hora de dormir etc? Como demonstra isso?

b. Ele realiza as atividades em casa mais ou menos no tempo planejado para sua realização? Ele demora muito ou é muito rápido para comer, se vestir, ir no banheiro, tomar banho etc? Espera sua vez para fazer as atividades? É impaciente, teimoso, quer fazer as coisas na hora que ele quer, não espera os outros etc?

\section{4) Relação com objetos}

a. Ele sabe quais objetos são dele, os que são da mãe, do pai, do irmão, da cozinha, do banheiro, do quarto? Como demostra isso?

b. Ele cuida dos objetos que fazem parte do cotidiano dele em casa? Como? Em que situações?

c. Ele sabe quais são as funções dos objetos e os usa de acordo com sua função (usa o lápis para escrever, desenhar, o copo para beber água, a bola para jogar, o carrinho para empurrar, etc.? Como você percebe isso? Em que situações)?

d. Como ele manuseia os objetos (como ele abre a porta, a pia, abre a caixa dos brinquedos, o pacote de bolacha, segura o lápis, o sabonete, etc.)? Ele precisa de alguma adaptação para estes manuseios? Por quê? Em que situações?

e. Quais são os brinquedos com os quais ele prefere brincar? Como você identifica isso?

\section{5) Relação com atividades}

a. Que atividades ele realiza em casa? Como? Em que situações? Precisa de adaptações para realizá-las? Exemplos: Ele tira sua própria roupa? Veste-se? Põe o sapato? Abotoa a calça, camisa? Vai ao banheiro sozinho? Abaixa as calças? Sabe se limpar, dar descarga? Lava a mão? Toma banho sozinho? Esfrega-se? Lava os seus próprios cabelos? É ele mesmo que põe seu xampu? Penteia-se sozinho? Escova os dentes? Ele come sozinho (com a colher, com o garfo, com a faca)? Ele é quem põe a comida no seu prato? Ele segura o copo e bebe sozinho? Ele põe a bebida no seu copo? Ele leva o prato para lavar? Ele assiste T.V.? Ele ajuda em alguma atividade doméstica? Ele vai junto com a família às compras, à casa de parentes amigos, passeios?

b. Ele brinca? Do quê ele brinca? Como ele brinca? Quais são os brinquedos preferidos dele? 


\section{Roteiro de observação do aluno no cotidiano em casa}

c. Ele prefere brincar sozinho ou com alguém em especial? Em que brincadeiras e atividades ele solicita a participação do outro? Por quê?

d. Quais atividades ele gosta? Quais atividades ele não gosta? Quais atividades ele rejeita realizar? Por quê? Como você percebe isso?

e. Ele demonstra compreender as atividades a serem realizadas no dia-a-dia em casa? Quais? Em que situações? Como demonstra isso? Que recursos são necessários utilizar para que ele compreenda?

$\Rightarrow$ Desde que seu filho estuda nesta escola, do início do ano até hoje, você percebe alguma mudança no seu desenvolvimento? Que mudança é esta? Como você percebe isto? 


\section{DIÁRIO DE OBSERVAÇÃO DO ALUNO}


Diário de observação do aluno

\begin{tabular}{|ll|}
\hline ESCOLA: & \\
\hline PROFESSOR (A): & \\
\hline ALUNO (A): & D.N.: \\
\hline
\end{tabular}

\section{DIÁRIO DE OBSERVAÇÃO DO ALUNO ${ }^{49}$}

Registrar fatos, situações, atitudes, ações, falas, comentários, observações e impressões que você considera significativo da relação do aluno com pessoas, espaço, tempo, objetos, atividades. Colocar a data de cada acontecimento.

Relação com as Pessoas

Relações com o Espaço

Relações com o Tempo

Relações com os Objetos

Relação com as Atividades

$\Rightarrow$ O que você espera que seu aluno desenvolva/aprenda no próximo mês?

${ }^{49}$ Este diário faz parte da pesquisa de campo da dissertação de mestrado de Deigles Giacomelli Amaro que está sendo desenvolvida no Programa de Pós-graduação em Psicologia Escolar e Desenvolvimento Humano no Instituto de Psicologia da USP, sob a orientação do Prof. Dr. Lino de Macedo. 
CRONOGRAMA DA PESQUISA DE CAMPO 


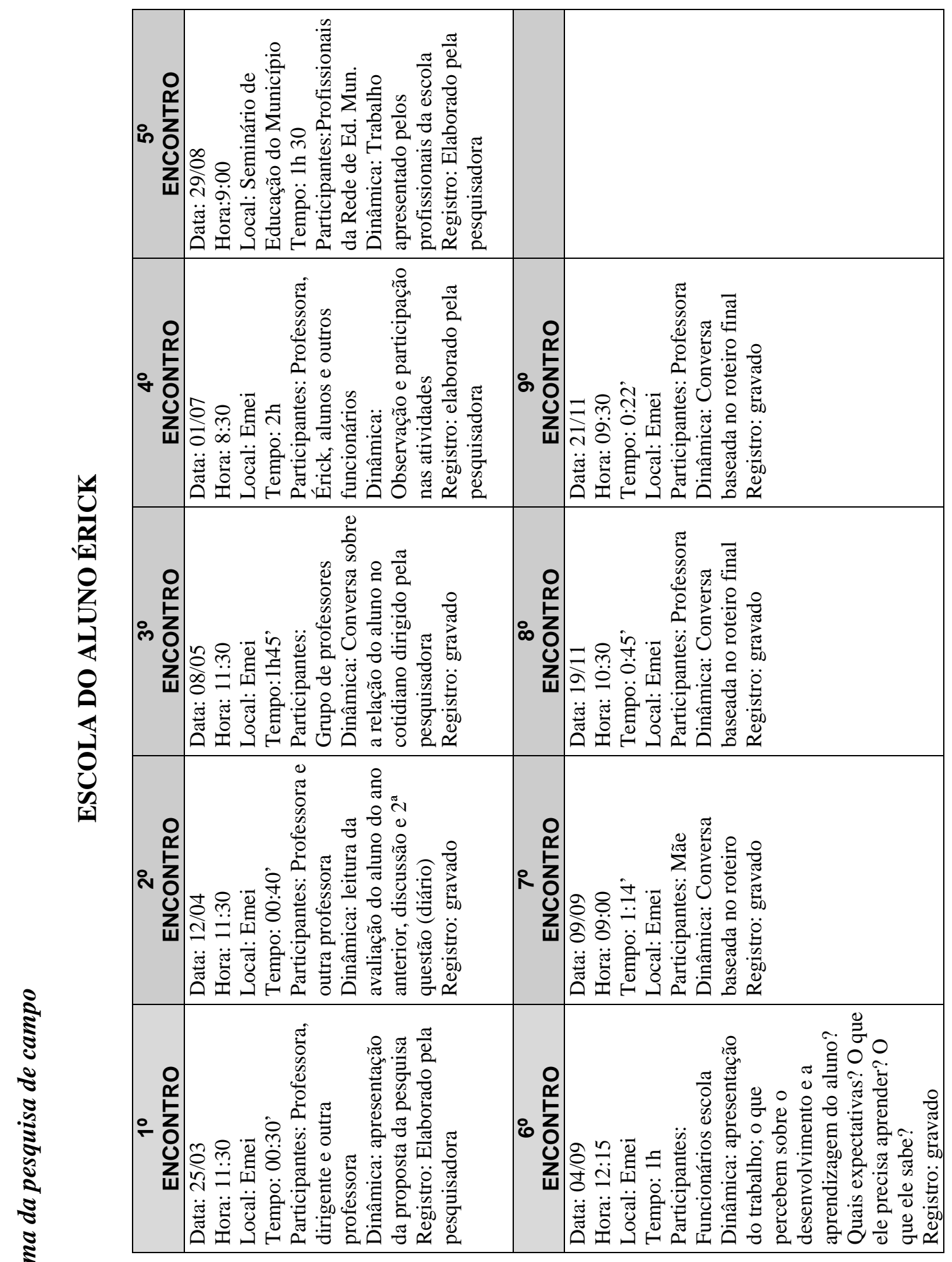




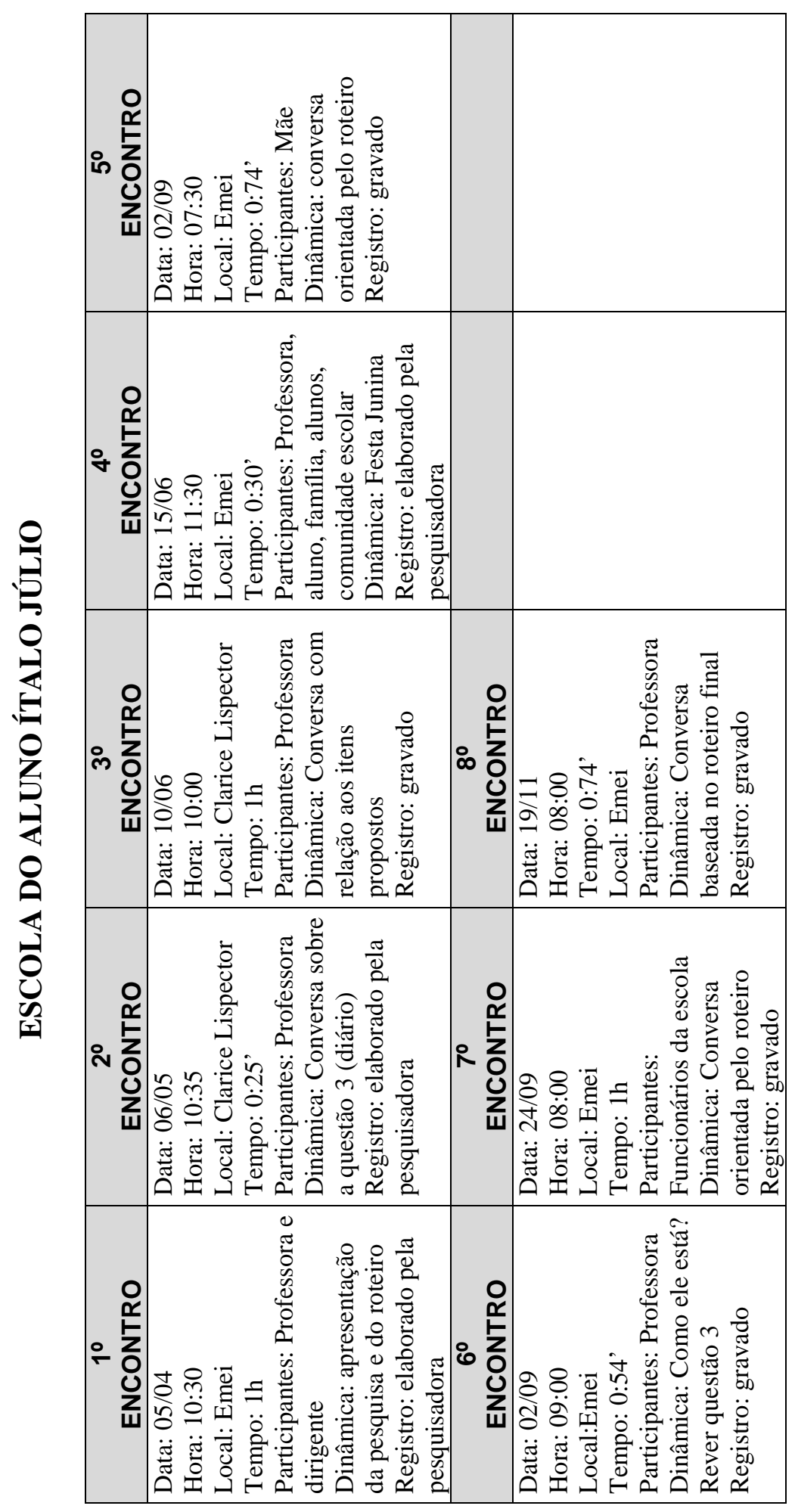


ANEXO 5

ROTEIRO DA ENTREVISTA FINAL DE COLETA DE DADOS DO ALUNO ÉRICK 


\section{Roteiro da entrevista final de coleta de dados do aluno Érick}

\section{Relação com pessoas}

- Os sons, balbucios, palavras que o aluno pronuncia são específicos para determinadas situações/pessoas?

- Que som, palavra, balbucio ele pronuncia que vocês identificam o que ele está querendo dizer?

- Ele se comporta envergonhadamente, é retraído? Em que situações, com que frequiência, com quais pessoas?

- Atualmente ele utiliza para se comunicar mais gestos, sons, balbucios, palavras, expressões faciais, movimentos corporais ou outros?

- Como interage com as pessoas na roda de conversa? Espera que alguém lhe pergunte algo para se manifestar ou se manifesta espontaneamente quando deseja?

- O que ele faz para chamar a atenção de alguém com quem quer se comunicar?

- Como está a integração entre o aluno e seus colegas?

- Quando e como ele solicita contato com outros colegas? Quando e como os outros colegas interagem com ele? As crianças compreendem o que ele quer dizer?

- Em quais momentos ele busca a interação com os demais?

- Como ele demonstra reconhecer seus colegas e demais funcionários da escola?

- Como está o movimento de sua mão/braço? Para que ele utiliza estes movimentos e como? Que influência você considera que o botox ${ }^{50}$ teve neste processo?

- Como está a postura do aluno?

- Você considera que seus movimentos correspondem a sua intencionalidade? Por quê?

- O que você acha da coordenação motora do aluno atualmente?

- Como ele reage quando seus colegas vão trocar sua toalhinha, colocar sua meia, sapato, etc?

- Ele demonstra reconhecer que ele tem a mesma idade, é mais ou menos do mesmo tamanho que seus outros colegas de sala? Como você percebe isso?

\section{Relações com espaço}

- Ele tem ficado mais no carrinho, chão ou em que outro lugar? Como normalmente ele se locomove?

- Quando está no chão, tenta alcançar alguém ou mudar de posição quando deseja alguma coisa?

- Ele solicita mudar de posição?

- Na sala de aula ele fica na mesa junto com seus colegas?

${ }^{50}$ Substância aplicada como intervenção terapêutica para diminuição do tônus muscular. 


\section{Roteiro da entrevista final de coleta de dados do aluno Érick}

\section{Relações com tempo}

- Acompanha o ritmo da música, da contagem? Que outras atividades você percebe que ele acompanha o ritmo, o tempo destinado para realização da atividade?

- Você percebeu mudança com relação ao tempo que ele necessita para comer?

- Você percebeu mudanças com relação a como e quando ele se movimenta na sala de aula, na escola ao longo do ano?

\section{Relações com objetos}

- Ele tem dividido e compartilhado os objetos seus e da escola com os colegas? Como demonstra se sentir ao fazer isso?

- Sente náusea ao contato com algum material da escola? Qual? Em que situação?

- Que objetos ele manuseia? Como? Em que situações?

- Que tipo de giz de cera ele está utilizando? Que adaptações estão sendo necessárias?

- Está tendo algum tipo de adaptação na folha que ele utiliza? Qual? Em que situação?

- Como tem sido a relação dele com a boneca?

\section{Relação com atividades}

- Que noções e conceitos você considera que o aluno desenvolveu? Ex. cores, formas, letras, números, gosto, temperatura, altura, posição, lateralidade etc.

- Compreende brincadeira de faz-de-conta? Quais? Em que situações?

- Como utiliza as cores?

- Tem interesse e compreende as atividades em folha?

- Quais atividades ele demonstra compreender o significado? Como ele demonstra esta compreensão e interesse?

- Entende que faz parte de um grupo de sala de aula, de uma escola?

- Vocês experimentaram escovar os dentes do Érick? Como foi?

- O que e como ele tem se alimentado?

- Como ele tem realizado as atividades em folha? É necessário ter um ponto de referência? Por quê? Que ponto é esse? O que ele tem como produto nessas atividades?

- Como tem sido o processo para ele realizar as atividades de desenho, pintura, brinquedos? Que tipo de auxílio e adaptação ele necessita?

- Ele responde as questões realizadas para o grupo de alunos? Como?

- O colega ou você tem que mostrar o dia no calendário? Por quê? Ele sabe reconhecer números?

- Ele tem segurado a colher na mão e feito o movimento (passivo) para levar comida a sua boca com auxílio da professora?

- Do quê ele está brincando?

- Como o aluno tem participado das brincadeiras? 


\section{Roteiro da entrevista final de coleta de dados do aluno Érick}

- Como reage em festas, música alta, barulho?

- O que ele acha de participar de atividades com outras salas de aula, ensaios?

- O que ele demonstra sentir ao contato com tinta, cola, areia?

- Que alimentos ele gosta?

- O que ele mais gosta na escola?

$\Rightarrow$ O que você acha que o Érick desenvolveu?

$\Rightarrow \mathrm{O}$ que você acha que ele aprendeu?

$\Rightarrow$ Suas expectativas com relação ao desenvolvimento e aprendizagem do aluno foram alcançadas? Quais? Por quê?

$\Rightarrow$ Como você descreveria o Érick hoje? 
ROTEIRO DA ENTREVISTA FINAL DE COLETA DE DADOS DO ALUNO ÍTALO JÚLIO 


\section{Roteiro da entrevista final de coleta de dados do aluno Ítalo Júlio}

\section{Relação com pessoas}

- Como o aluno interage com as pessoas da comunidade escolar? Falando, com gestos, apontando?

- Como está a inteligibilidade de sua fala? Fala palavras, frases?

- Precisa ser questionado para falar?

- Como se expressa no dia-a-dia?

- Como pede as coisas que quer?

- Responde aos outros quando solicitado?

- Agradece ao outro quando lhe é feito um favor?

- Como está sua participação, comunicação e relacionamento com os colegas?

- Troca os brinquedos com os colegas?

- O que faz para chamar a atenção dos outros?

- Bate palmas e ri quando fazem o que quer?

- Ele está retraído, carinhoso?

- Sabe que seu nome também é Ítalo? Reconhece-se por este nome?

- Sabe e pronuncia os nomes de seus colegas e de colegas de outras classes?

- Precisa que um colega lhe dê a mão para ir para a sala?

- Distingue os funcionários pela sua função: merendeira, secretária, vigia, faxineira?

- Quais funcionários conhece, sabe e pronuncia o nome?

- Quais são as pessoas de referência para Júlio?

- Como se comporta quando pessoas diferentes falam com ele?

- Dá atenção para quem não conhece ou só para quem conhece?

- Quando em contato com outros professores e funcionários, faz alguma coisa para chamar a atenção deles?

- Como se comporta quando é valorizado ou quando realiza alguma atividade de maneira correta?

- Como se comporta quando se pergunta ou pede para ele que faça alguma coisa?

- O que faz com seu corpo para chamar a atenção do outro?

- Como está seu hábito com relação a limpeza do nariz? Percebe sem que o outro o avise que precisa ser limpo? Vai buscar o papel? Precisa de algum auxílio nesta atividade?

- $\quad$ Diz o que quer e o que não quer?

- O que ainda depende dos outros com relação ao seus cuidados pessoais e outras atividades da rotina da escola? Coloca a mão no mingau na hora do café?

- Como utiliza as partes de seu corpo nas atividades do dia-a-dia?

- Gosta de mexer com água? Percebe que está se molhando quando mexe na água? Está brincando com a canequinha e toalhinha na hora de escovar os dentes?

- Como está seu equilíbrio e coordenação motora no andar, segurar e levar objetos de um lugar para o outro, no chutar a bola?

- Coordena dois movimentos distintos juntos? Ele se senta sozinho na cadeira? Tira e põe sua mochila das costas sozinho?

- Que tipo de auxilio necessita nas atividades cotidianas?

- Localiza as partes de seu corpo nas brincadeiras?

- Abaixa e levanta suas calças sozinho, põe e tira sua blusa? Está dando descarga?

- Ele sabe que é sua a imagem refletida no espelho?

- Ele se reconhece em fotos e fitas de vídeo? 


\section{Roteiro da entrevista final de coleta de dados do aluno Ítalo Júlio}

\section{Relações com espaço}

- Sabe onde é o banheiro de baixo? Está utilizando-o? Quando o utiliza?

- Sabe onde é a sala das outras professoras? Precisa de alguma pista para identificá-las? Quando se dirige a estas salas?

- Sabe onde é o lugar em que se guardam os objetos do dia-a-dia da escola? Guarda-os espontaneamente ou é necessário pedir a ele ou lembrá-lo?

- Chega ou vai embora no colo da mãe?

- Precisa que alguém lhe de a mão para ir para a sala, para subir as escadas etc.? Precisa segurar no corrimão para subir e descer as escadas?

- Anda em lugar com desníveis?

- Corre em algum momento?

- Aceita ajuda de colegas para se locomover? Quando? Por que não?

- Precisa de ajuda para se sentar sozinho e tirar a mochila das costas?

- Tem lugar fixo para sentar? Sabe que lugar é este?

- Respeita e fica organizado na fila?

- Quais objetos do cotidiano sabe onde é que se localizam e/ou guardam?

- Guarda o produto de suas atividades na pasta e esta no seu respectivo lugar?

- Guarda brinquedos dentro da caixa, lápis e giz de cera na caixa, etc.?

- Se arrisca a jogar bola ao cesto quando a distância é um pouco maior do que a que estava acostumado?

\section{Relações com tempo}

- Ele necessita de um tempo maior do que o normalmente planejado para a realização das atividades cotidianas? Quais? Por quê?

- Demonstra reconhecer a rotina das atividades na escola pelo horário ou sequiência das atividades? Sabe que quando chega é a hora da roda da conversa, depois é o parque, depois é a merenda etc? Como demonstra isso?

- Faz as atividades da rotina espontaneamente ou precisa ser lembrado?

- Quando e como o aluno se movimenta na escola?

\section{Relações com objetos}

- Quais objetos ele sabe que são seus? Quais ele sabe que são da escola ou de outra pessoa? Como ele demonstra isso?

- Ele cuida dos objetos que fazem parte do cotidiano da escola? Quais (Ex: mesa, lápis, cadeira, massinha, seus sapatos etc)? De que forma?

- Como ele utiliza os objetos e brinquedos do dia-a-dia da escola? Usa de acordo com a função? Usa-os para brincar de faz-de-conta?

- O aluno consegue dar descarga? Apertar a pasta de dente? Rosquear e desrosquear as tampas da pasta de dente, potes etc? Consegue abrir as caixas dos brinquedos? Consegue utilizar a tesoura?

- É preciso diminuir a quantidade de leite na jarra para que ele consiga se servir?

- Quais os brinquedos de preferência do aluno? Como você identifica isto? 


\section{Roteiro da entrevista final de coleta de dados do aluno Ítalo Júlio}

\section{Relação com atividades}

- Como está sua atenção nas músicas e danças?

- Como está sua atenção e interesse nas atividades de vídeo/T.V.?

- Como está sua atenção, interesse, participação e comunicação na roda de conversa?

- Tem noção de quantidade? Como você percebe isso?

- Que cores ele conhece? Como demonstra este conhecimento?

- Tem noção de lateralidade? Como demonstra isso?

- Quais outras noções e conhecimentos ele tem?

- Que atividades e brincadeiras do dia-a-dia ele compreende? Que tipo de orientação e auxílio ele necessita para entendê-las?

- Ele brinca de faz-de-conta?

- Que atividades do dia-a-dia o aluno realiza? Em que situações? Como o faz? Que tipo de ajuda necessita? Precisa de adaptações para realizá-las (de conteúdo, de forma de tempo, dos objetos)?

- Atribui significado, representação simbólica as montagens que faz com blocos de montar e massinha?

- Quais atividades do cotidiano da escola ele auxilia a professoras, os colegas a realizarem?

- Como encaixa e desencaixa os brinquedos?

- Como está a sua participação nas atividades em que tem que falar (roda da conversa, por exemplo)?

- Como está seu interesse e realização nas atividades gráficas? Está realizando garatujas, utilizando várias cores, assinando do seu jeito o desenho, mostrando para os outros o que fez, guardando as atividades em sua pasta ou no varal? Faz rabiscos na lousa?

- Come todas as comidas que põe no seu prato? Identifica o que gosta ou não antes de por? Come as frutas quando elas não estão picadas?

- Demora para colocar geleia e margarina no pão?

- Serve-se sozinho? Vai pedir mais comida quando quer?

- Limpa a sujeira que faz?

- Rosqueia a tampa da pasta de dente? Põe pasta na escova? Leva sua caneca e toalha na hora de escovar os dentes?

- Precisa que lhe pergunte se quer ir ao banheiro? Manifesta espontaneamente seu interesse para ir ao banheiro? Que tipo de orientação ou auxílio necessita nesta atividade?

- Necessita que o coloque em algum brinquedo? Qual? Necessita que lhe dê a mão no escorregador? Escorrega sentado ou deitado? Que outras atividades realiza no parque? Precisa de auxílio nas atividades do parque? Qual?

- Como está sua participação no jogo de bola (futebol)?

- Que atividades faz sem precisar de auxílio?

- Como o aluno brinca? Em que situações ele estrutura brincadeiras? Como você percebe isso?

- Ele prefere brincar sozinho, com os colegas ou com o professor? Em que brincadeiras e atividades ele solicita a participação de outro? Por quê? Quais atividades ele gosta? Quais atividades ele não gosta? Quais atividades ele rejeita realizar? Por quê? Como você percebe isso? 
Roteiro da entrevista final de coleta de dados do aluno Ítalo Júlio

$\Rightarrow$ O que você acha que o Ítalo Júlio desenvolveu?

$\Rightarrow$ O que você acha que ele aprendeu?

$\Rightarrow$ Suas expectativas com relação ao desenvolvimento e aprendizagem do aluno foram alcançadas? Quais? Por quê?

$\Rightarrow$ Como você descreveria o Ítalo Júlio hoje? 
INDÍCIOS DO DESENVOLVIMENTO E DA APRENDIZAGEM DO ALUNO ÉRICK 


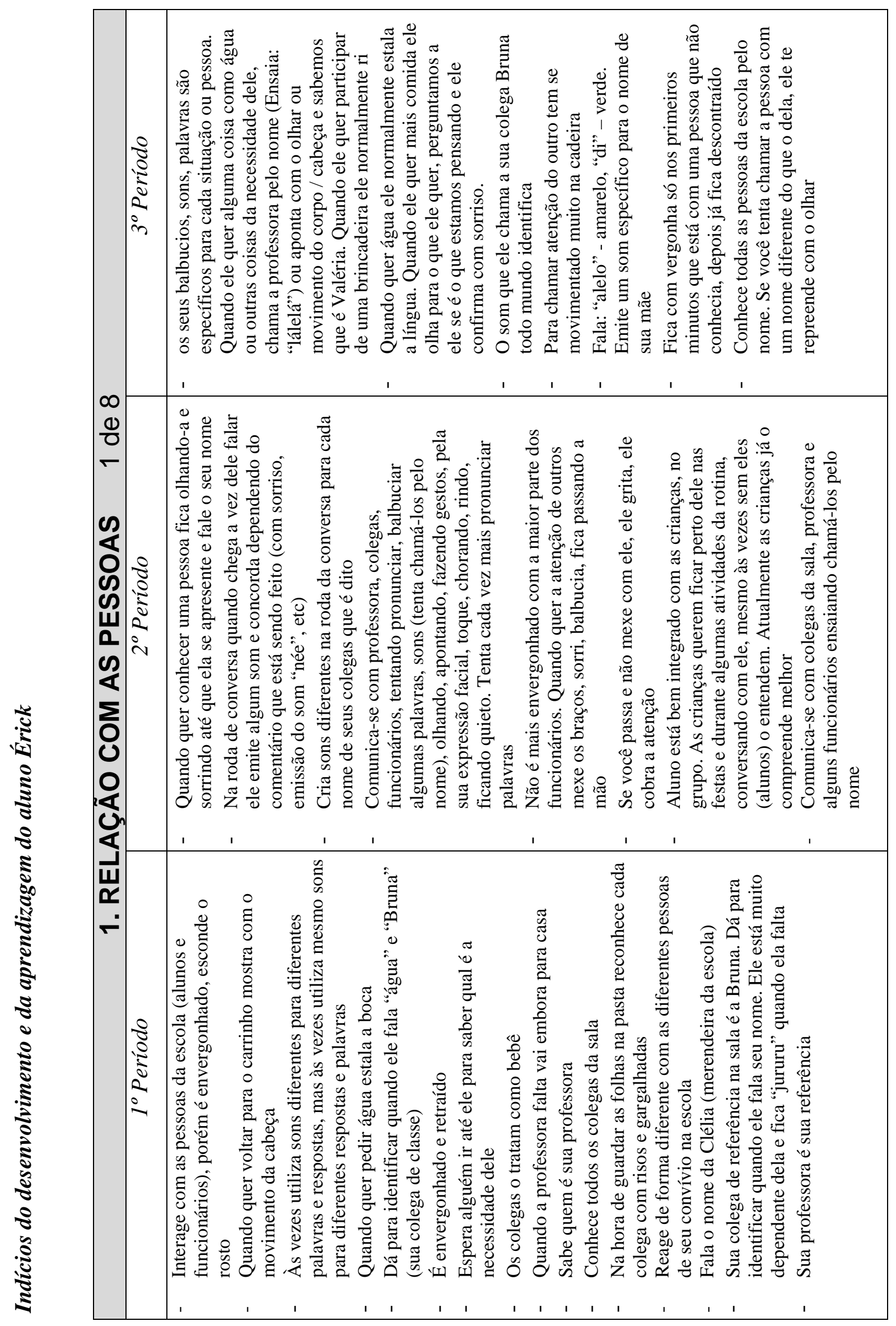




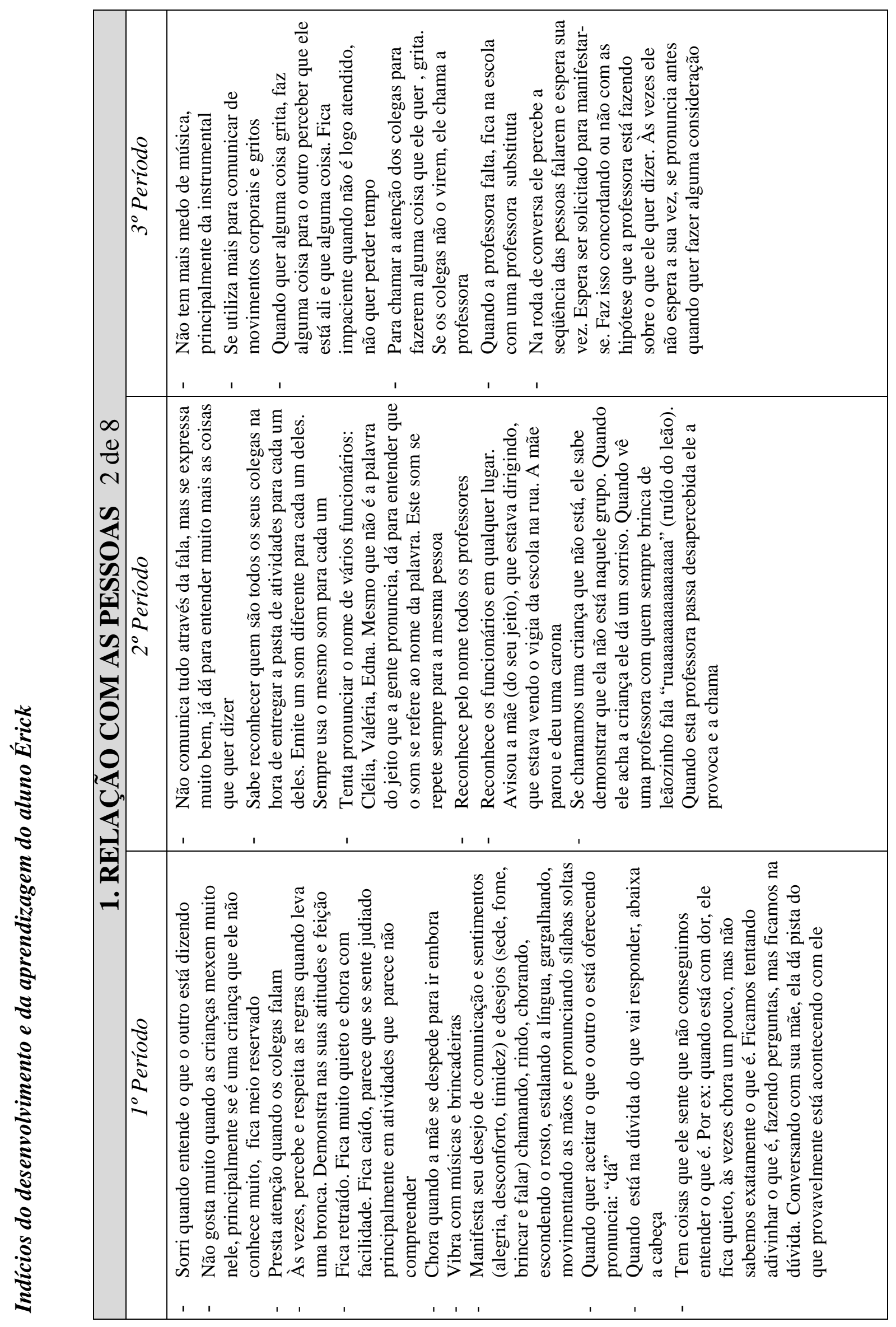




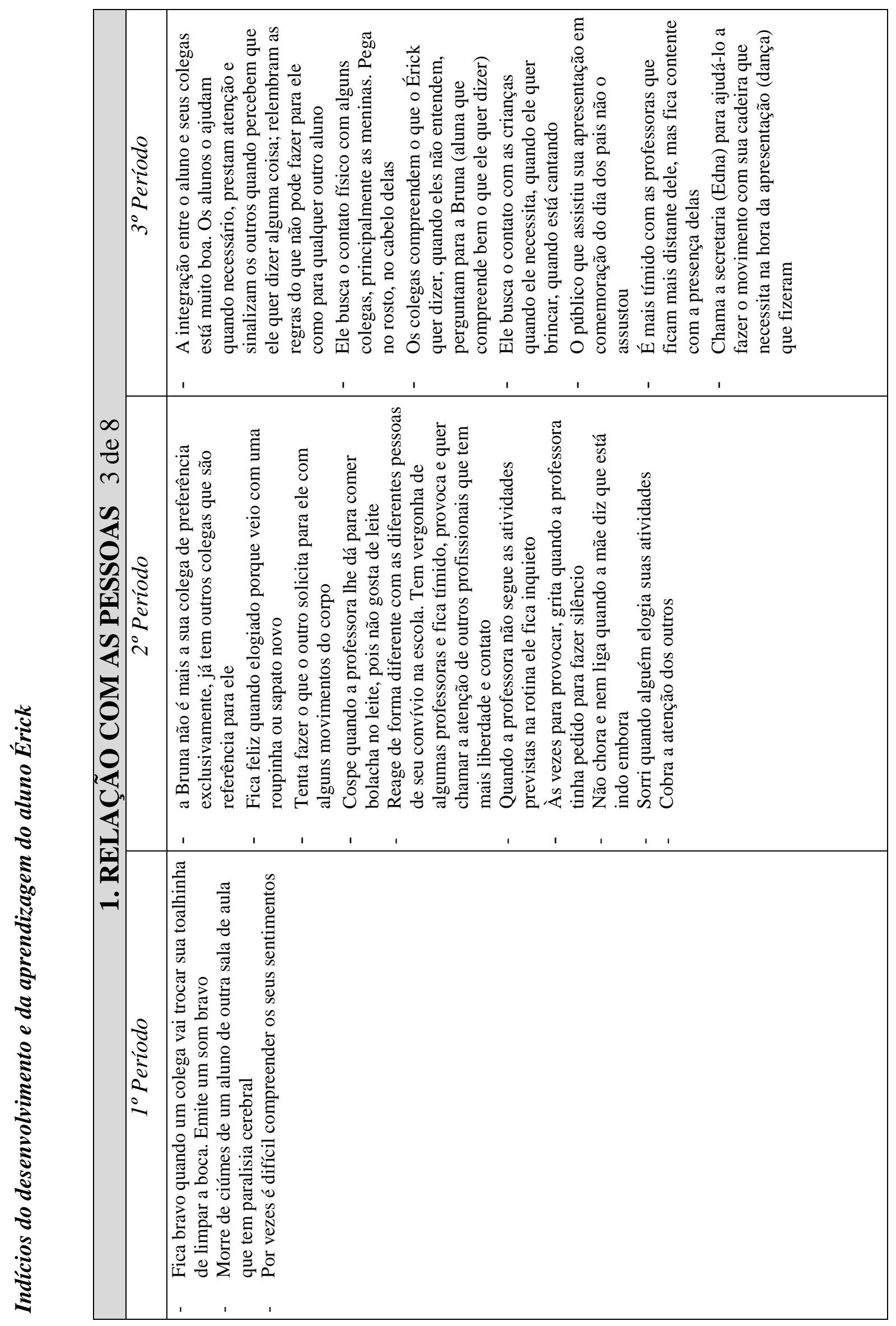




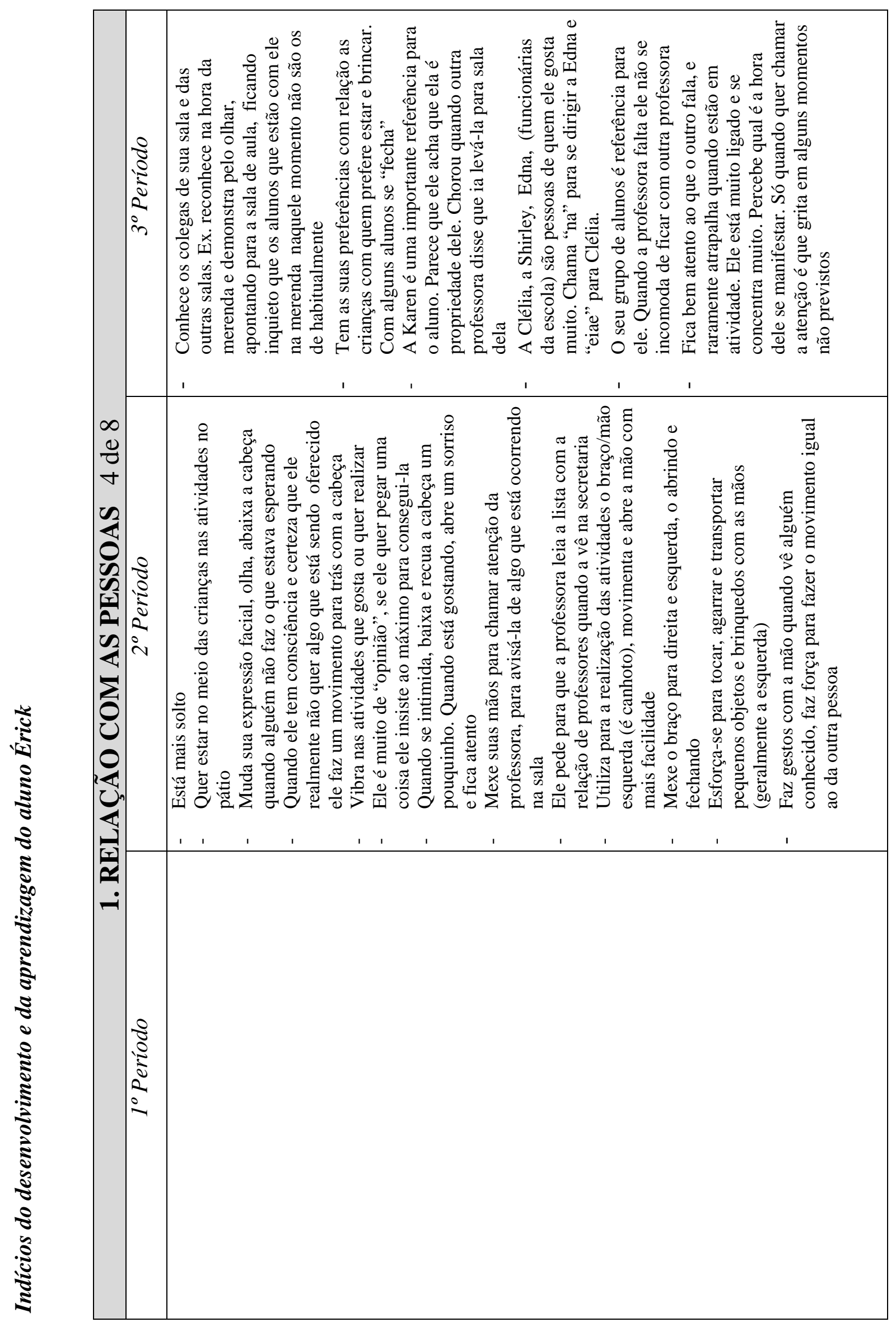




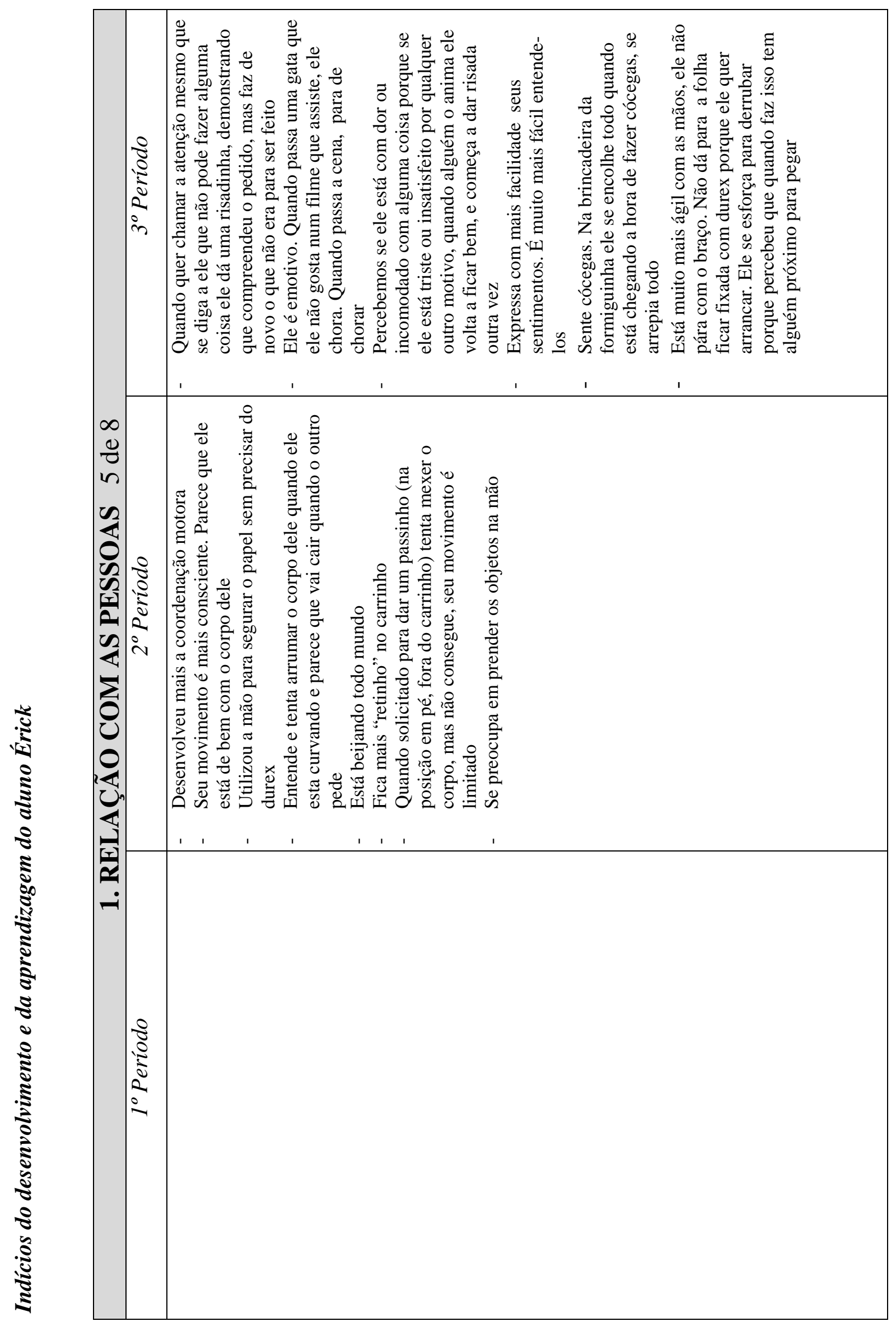




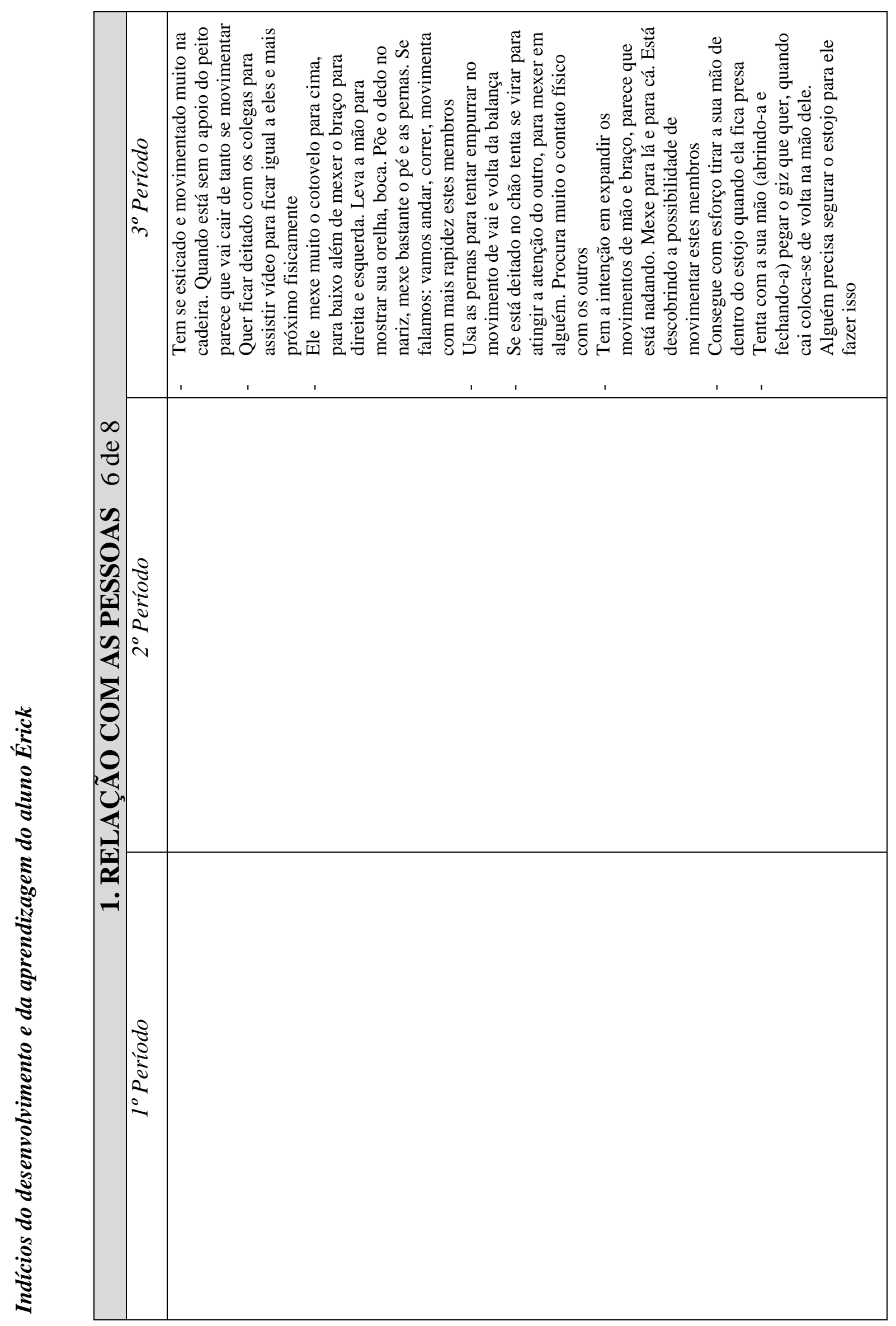




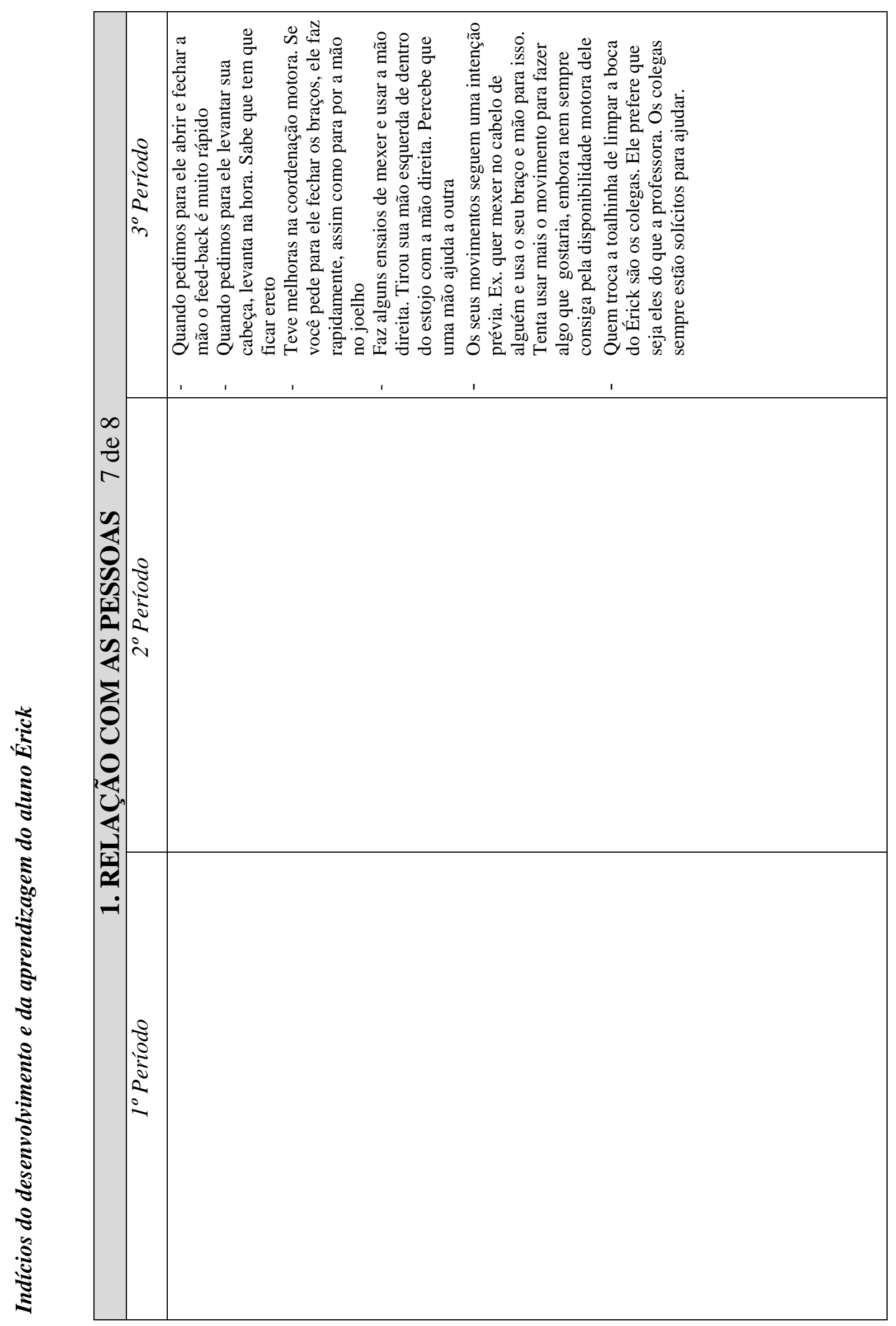




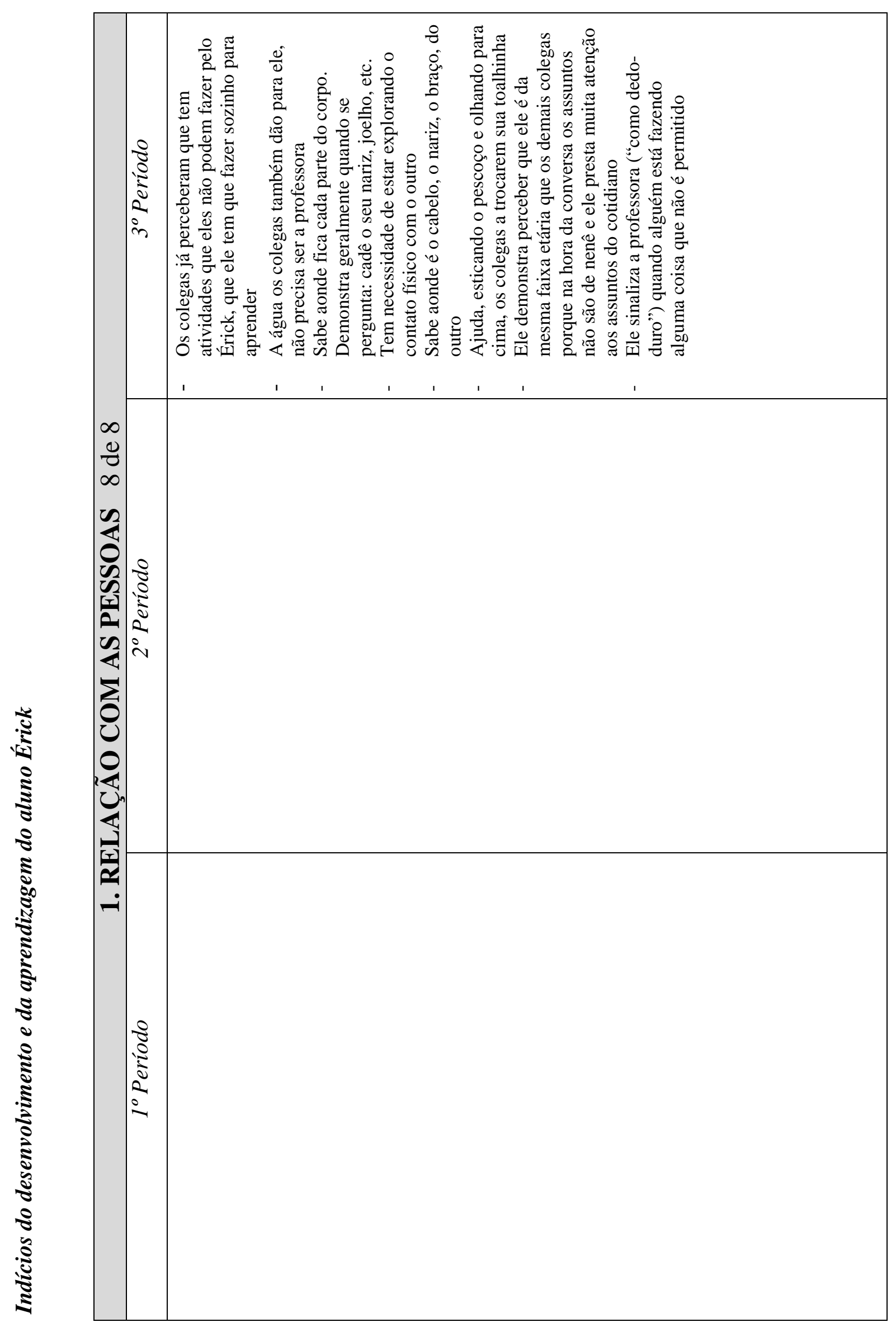




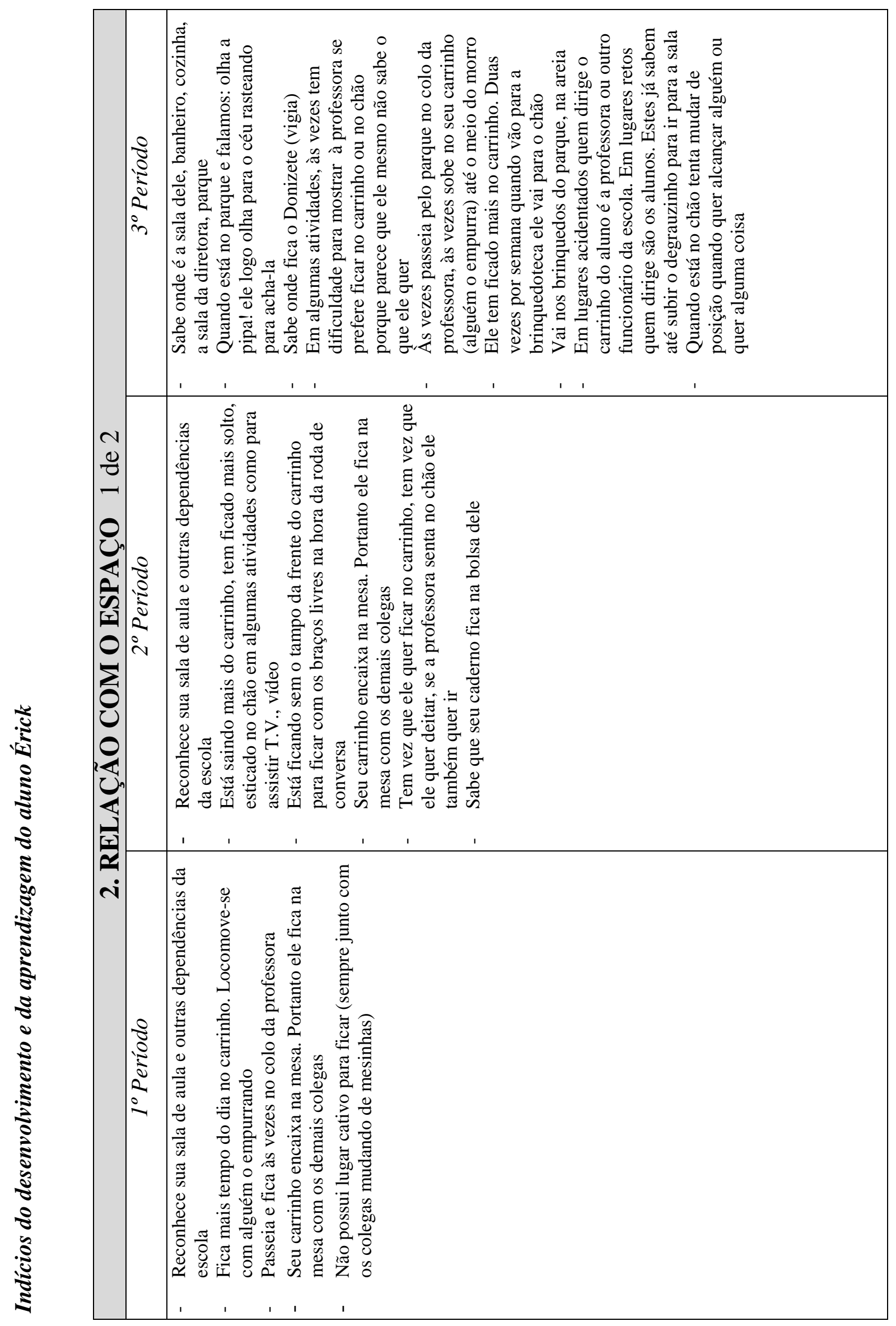




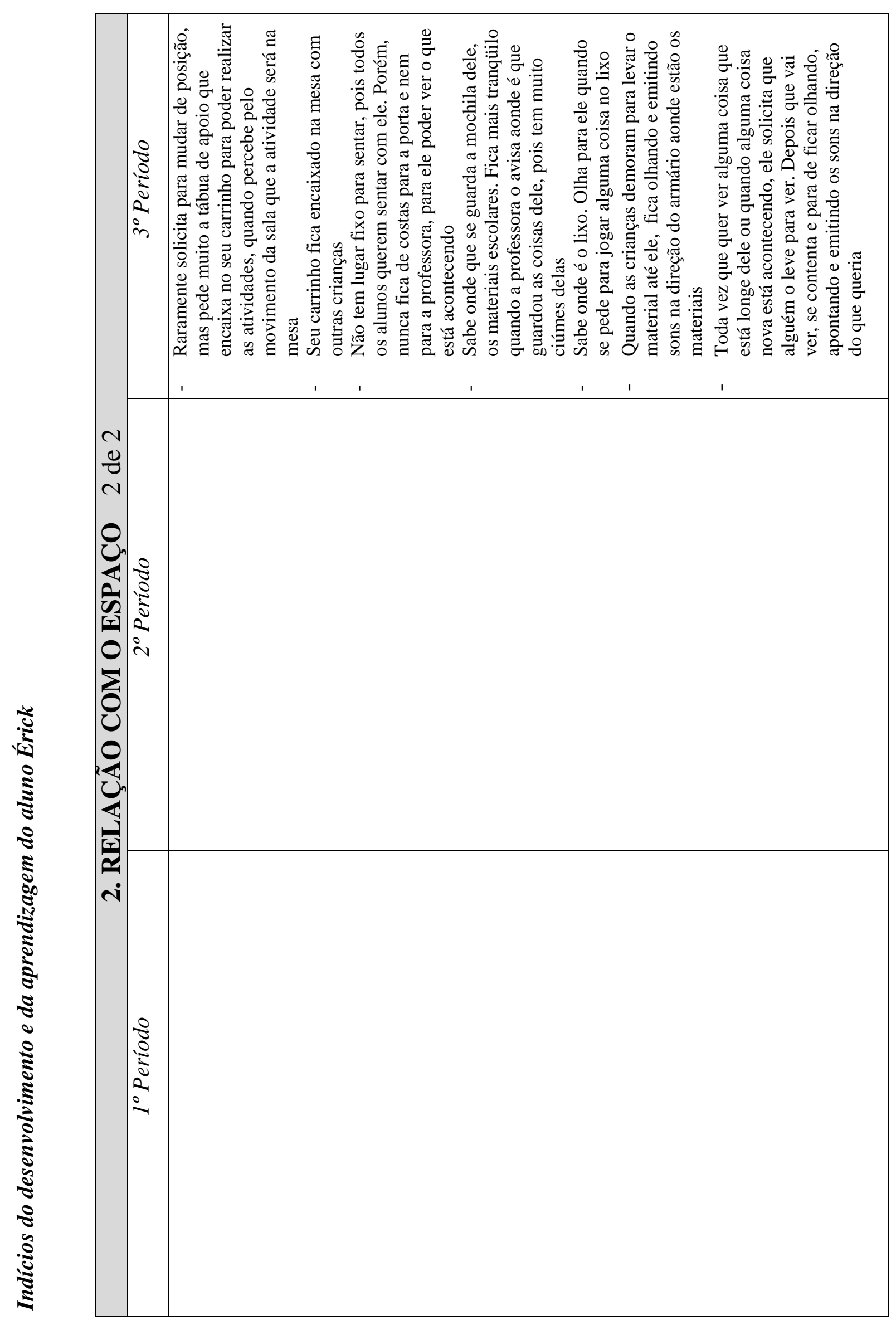




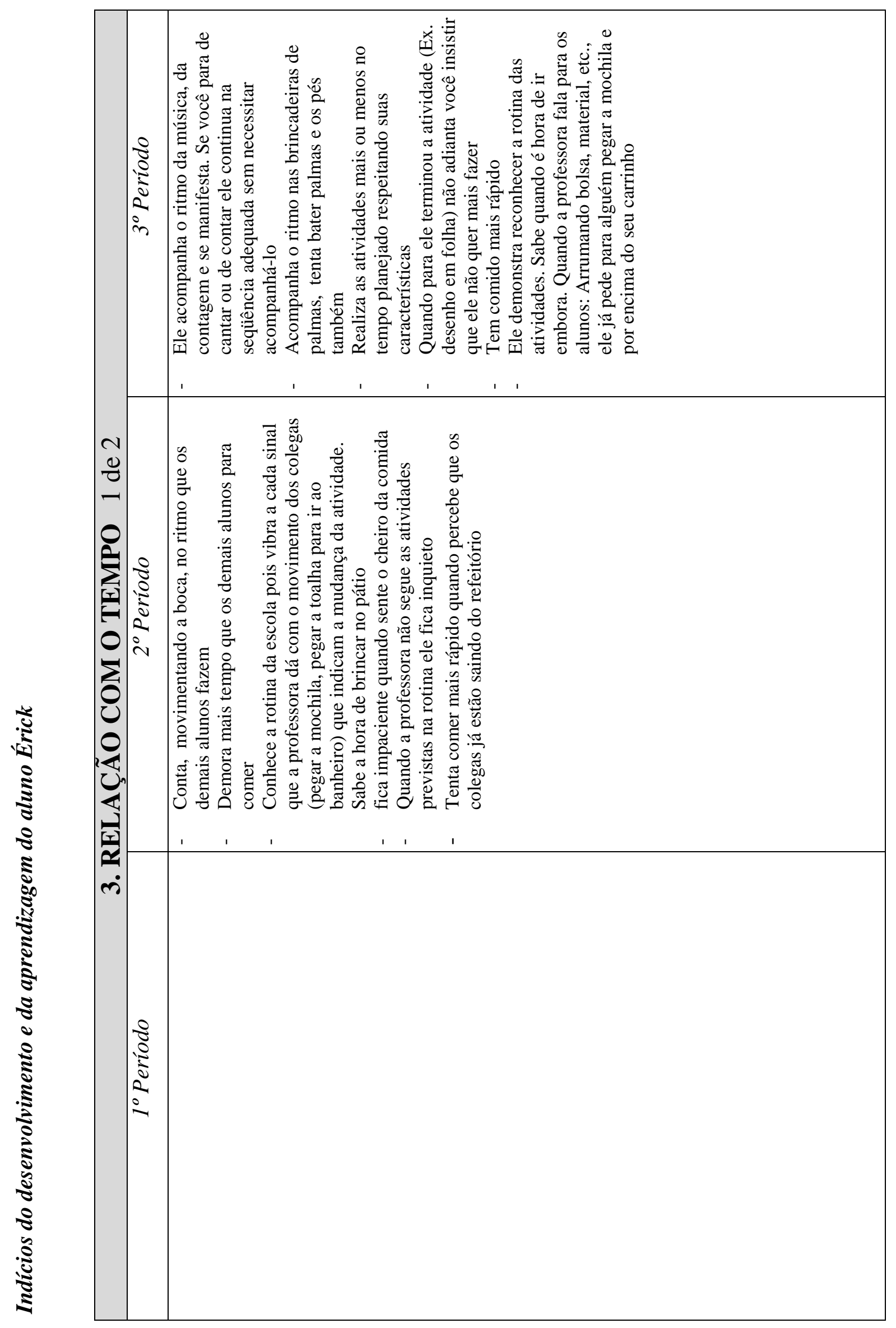




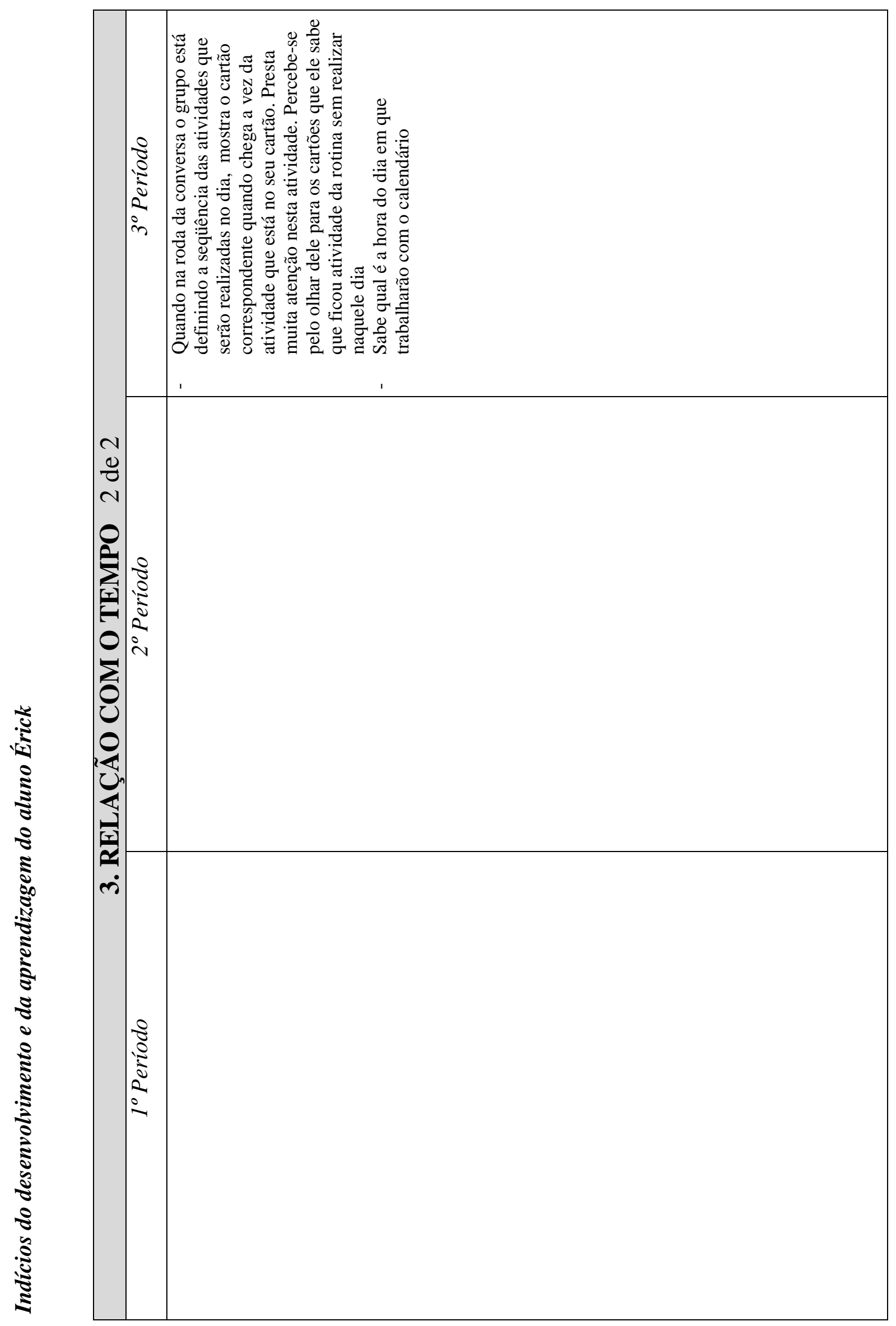




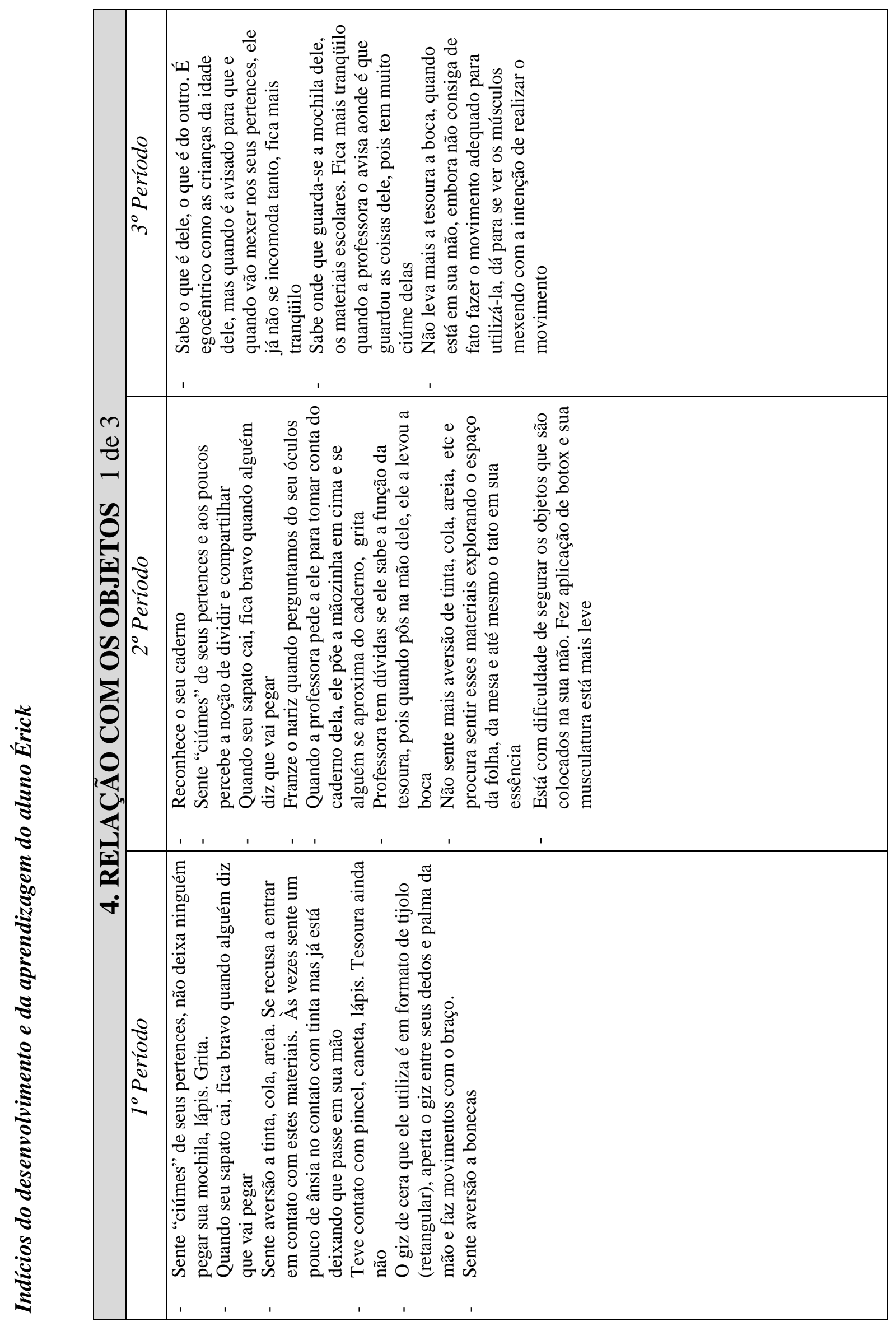




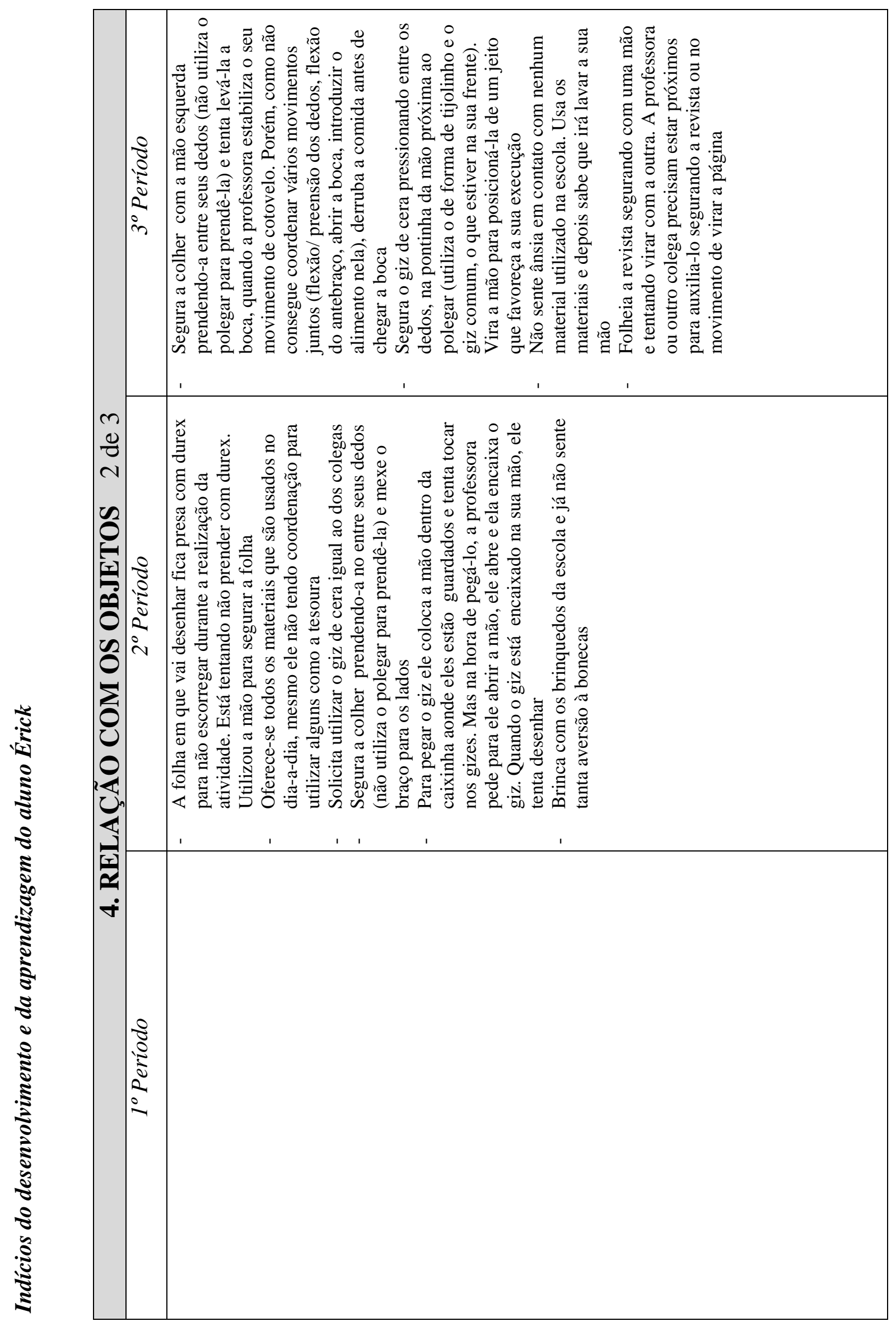




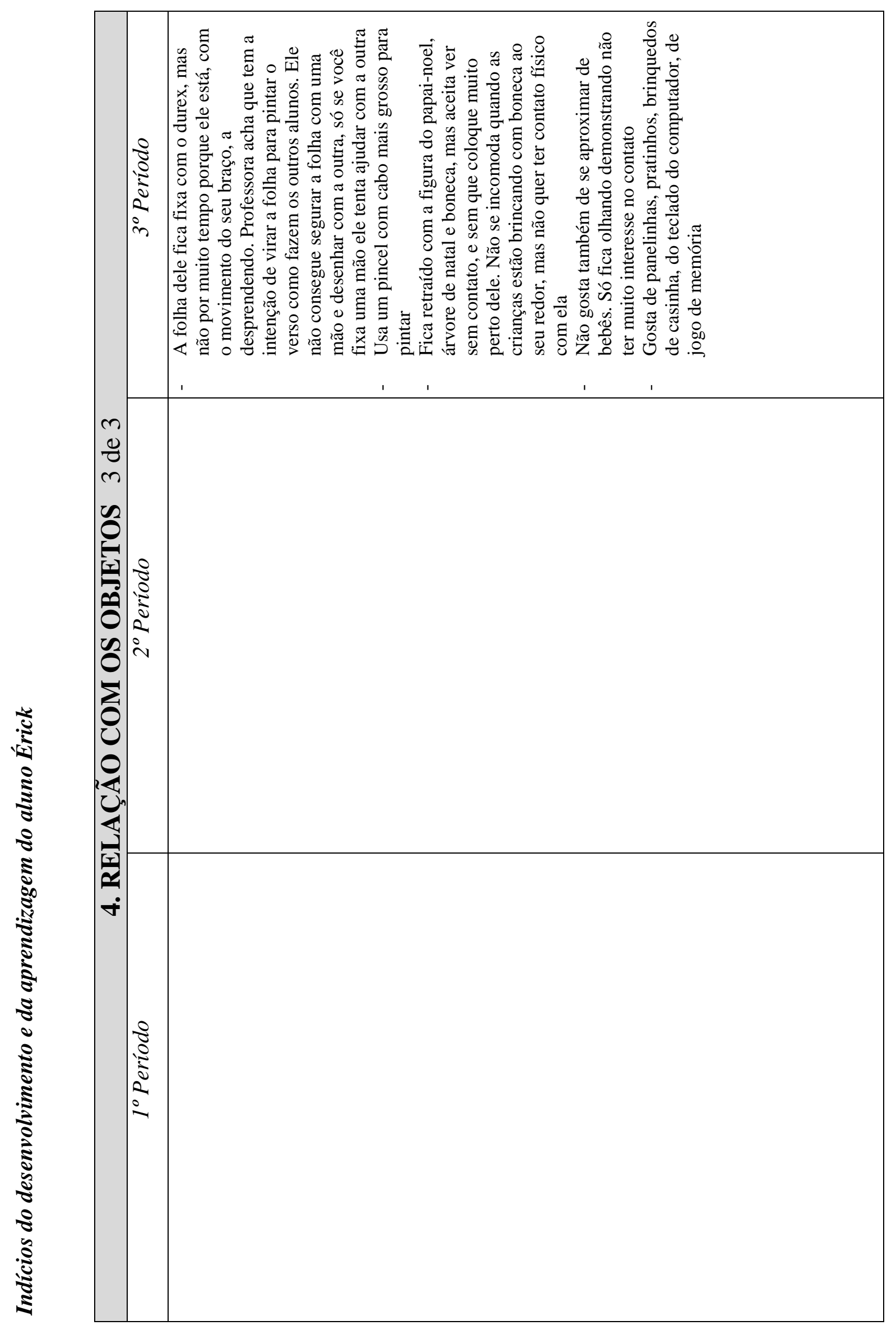




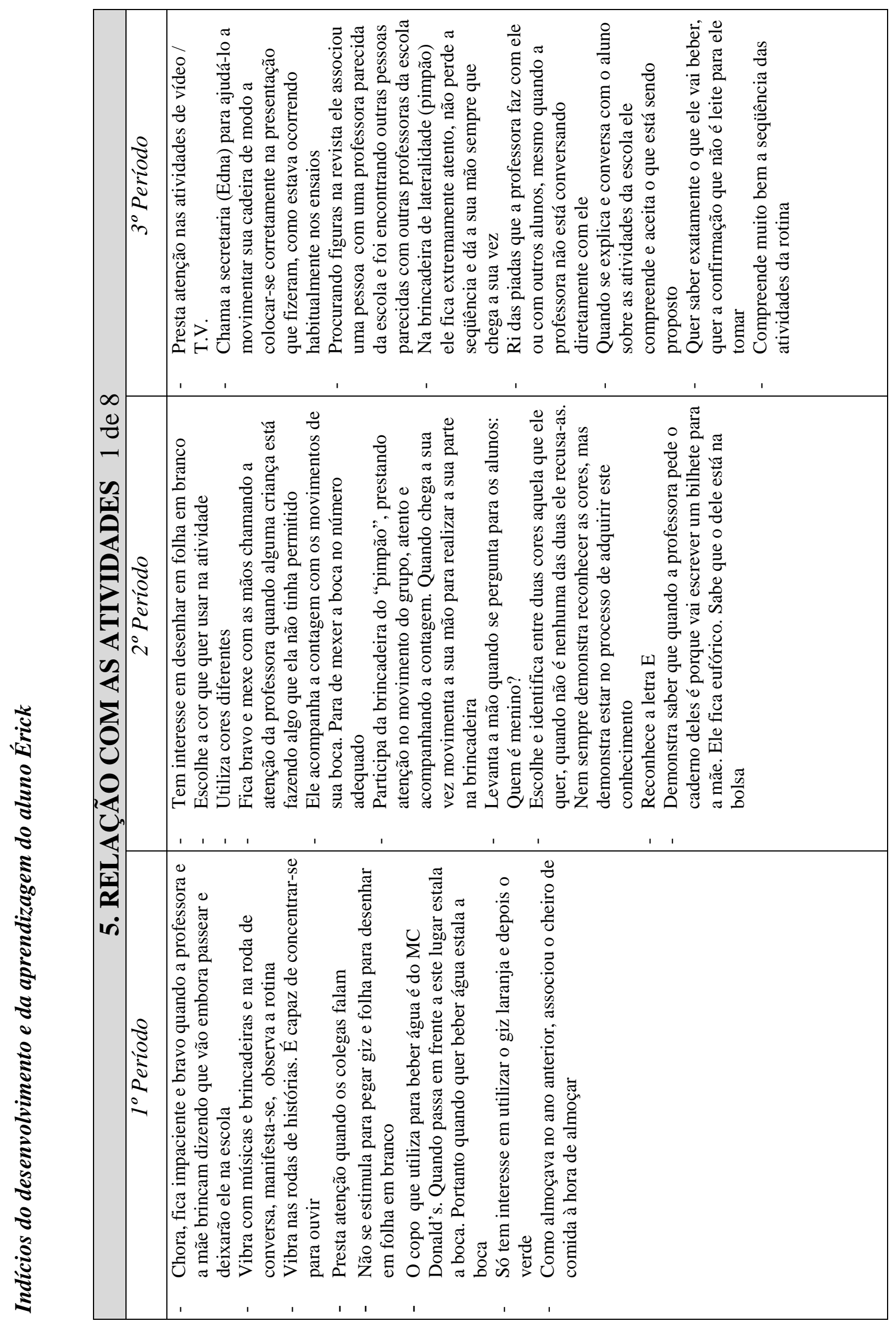




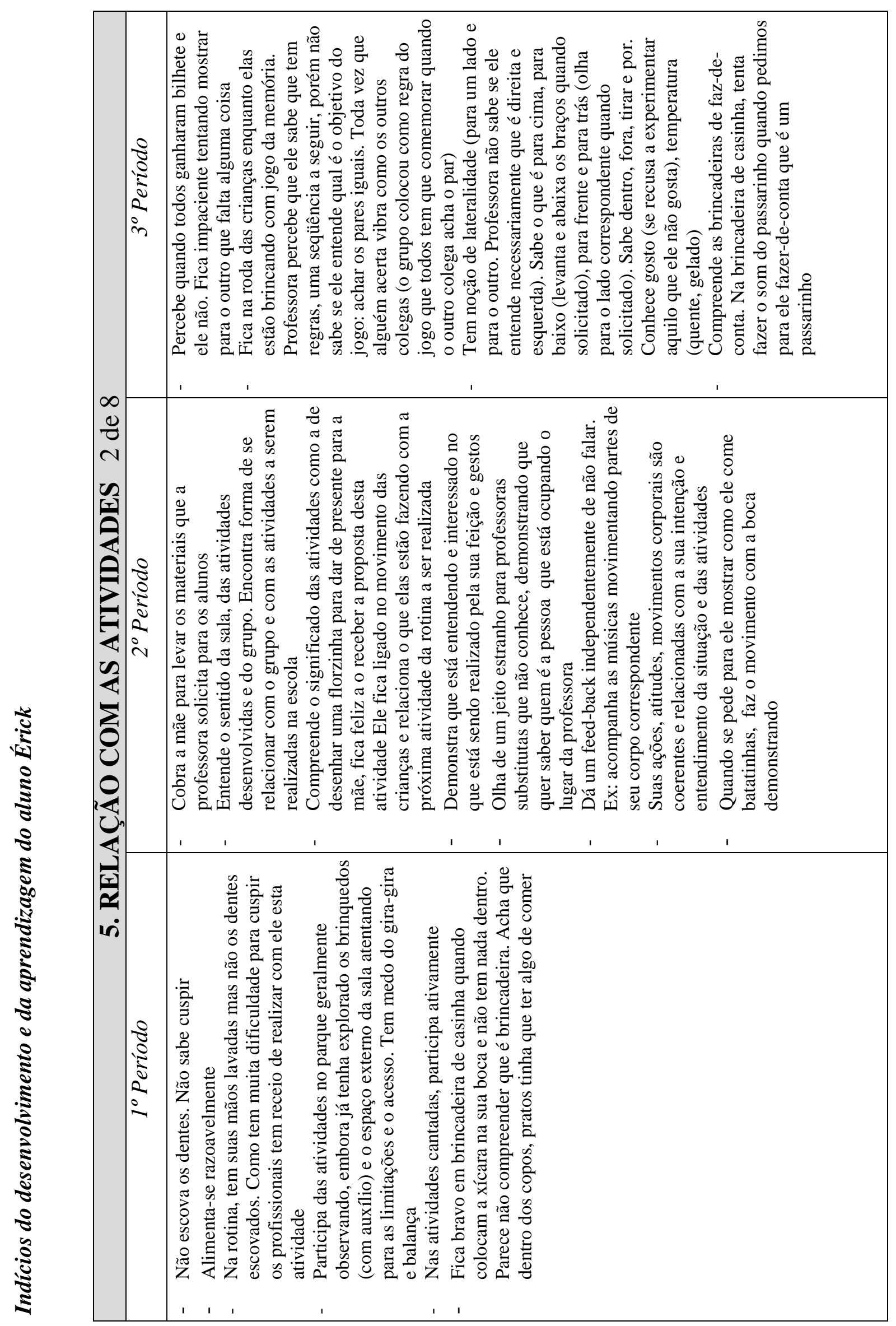




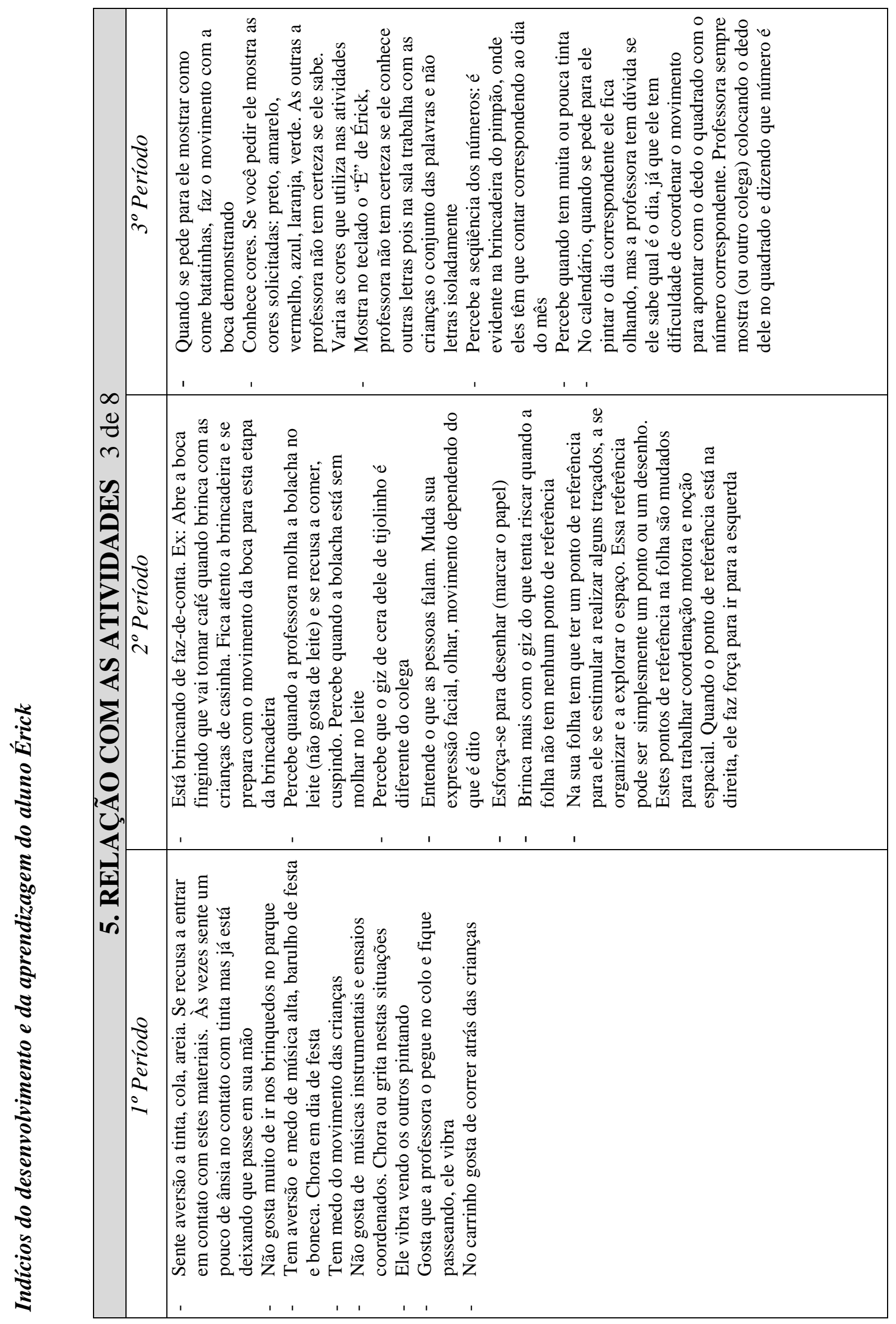




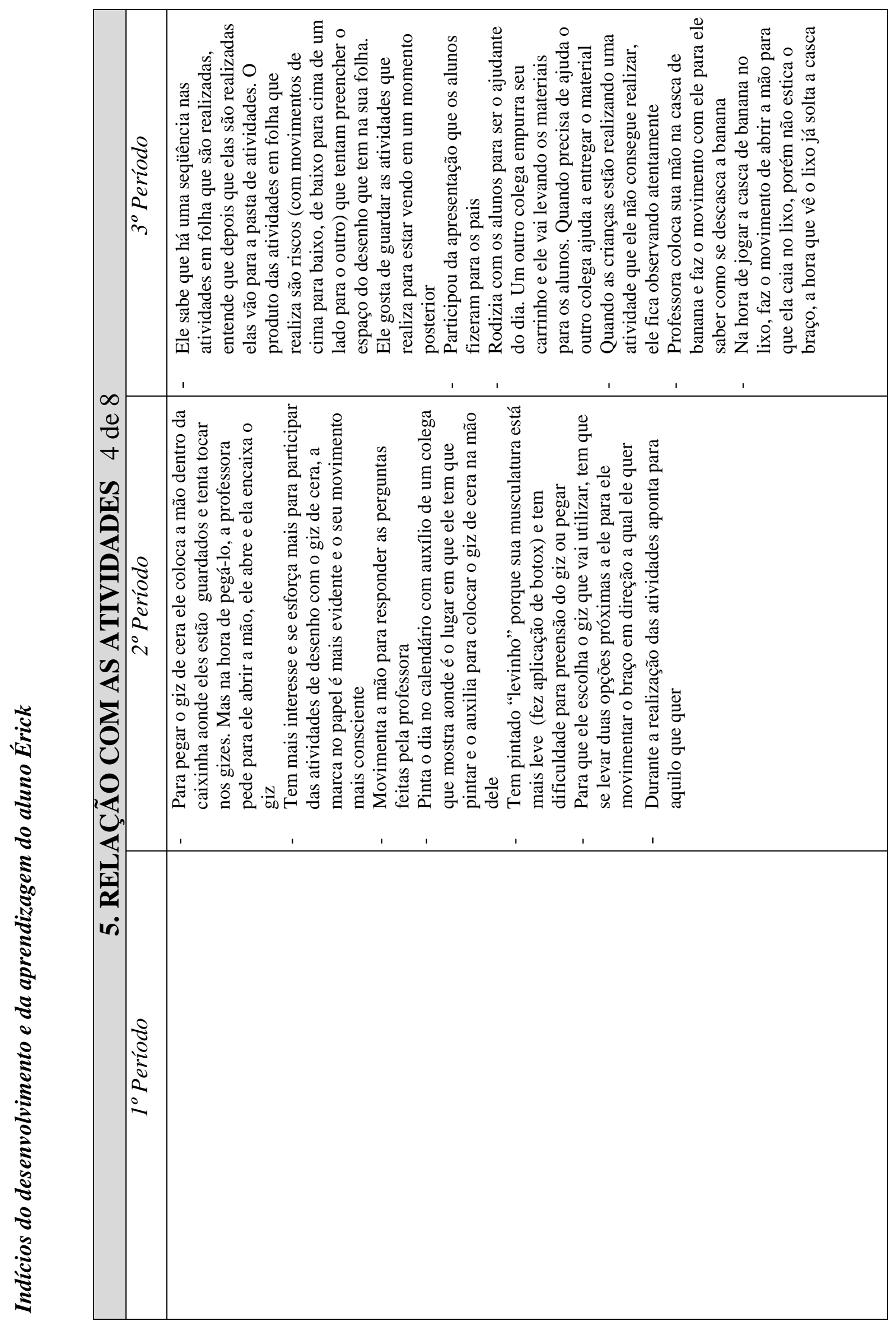




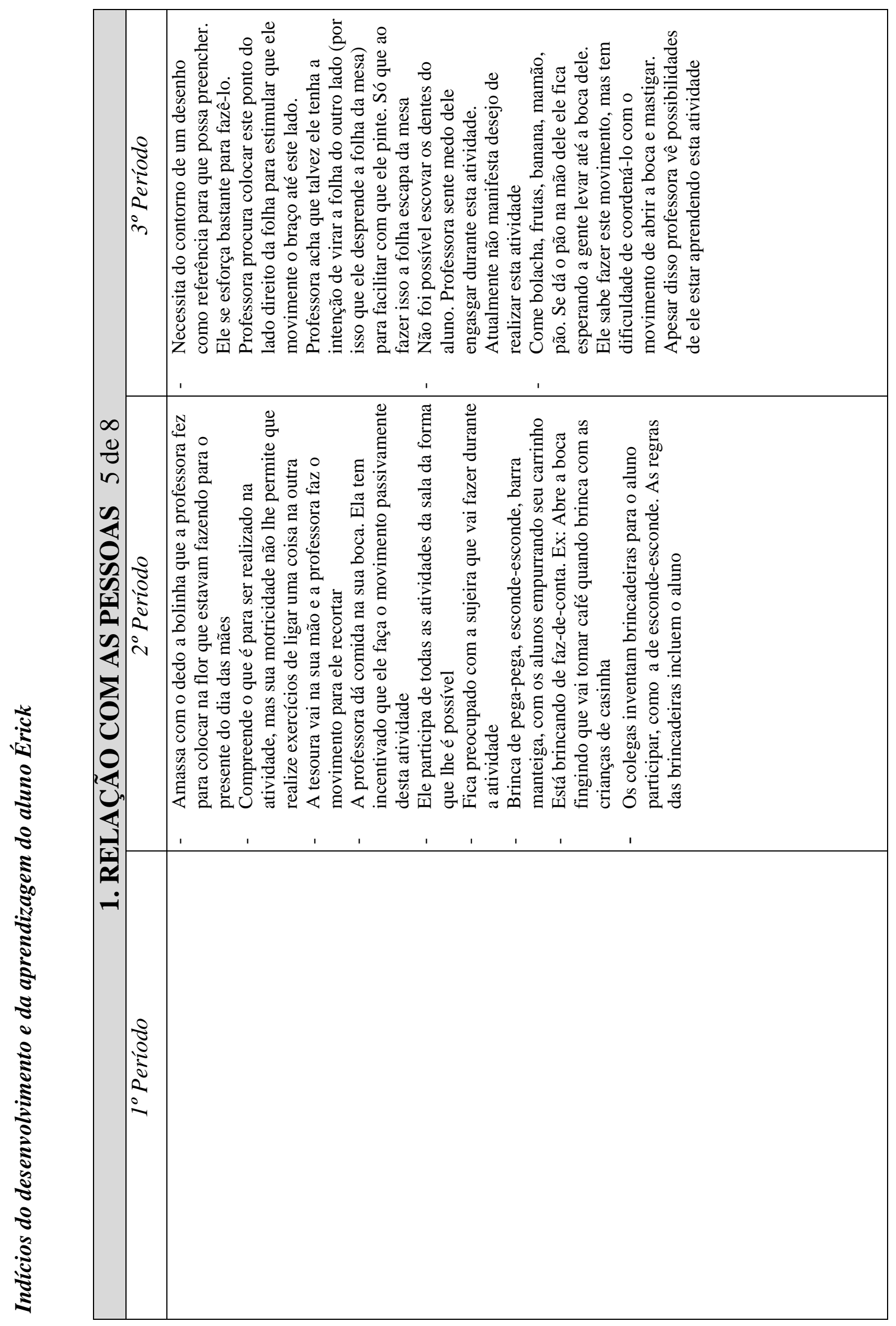




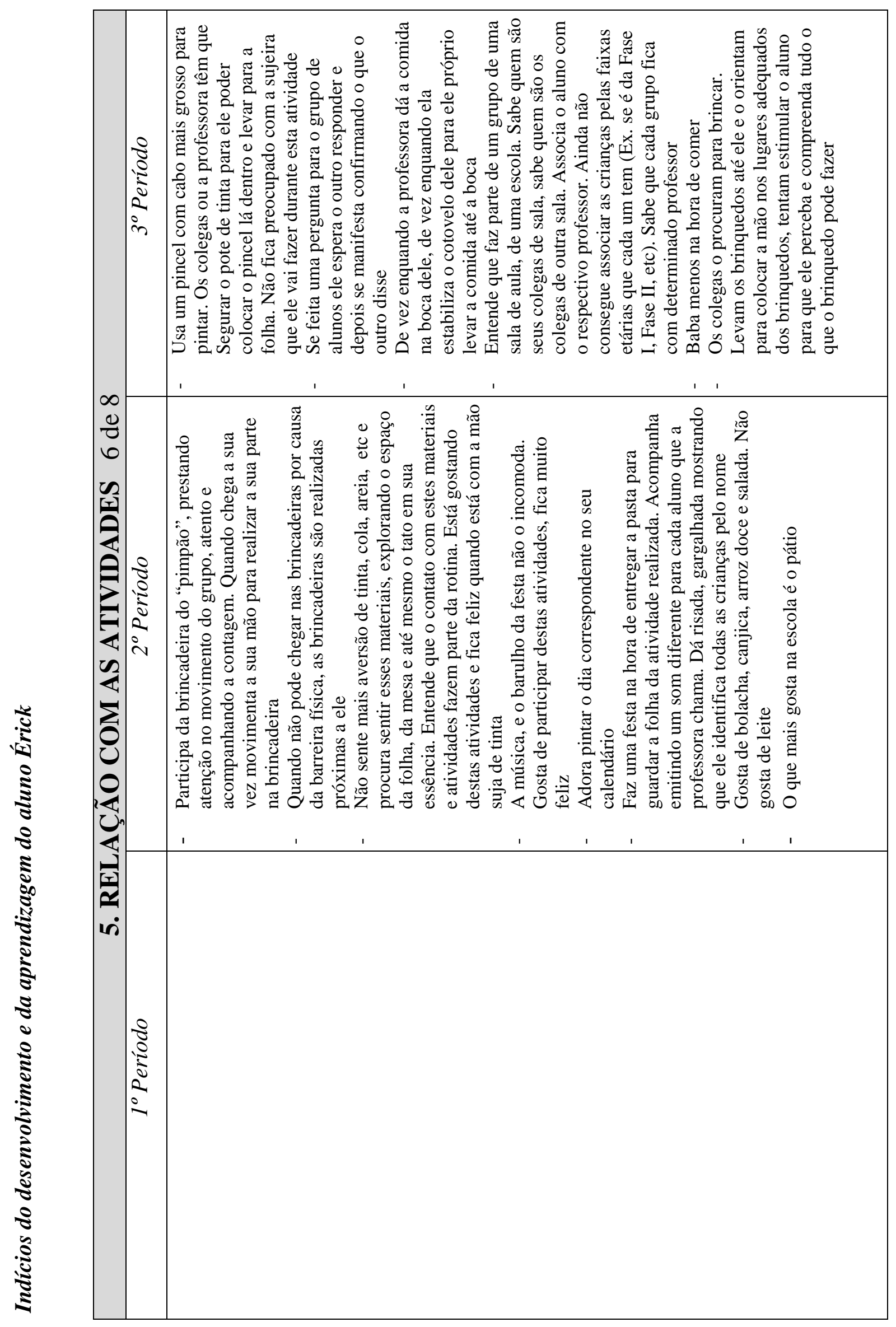




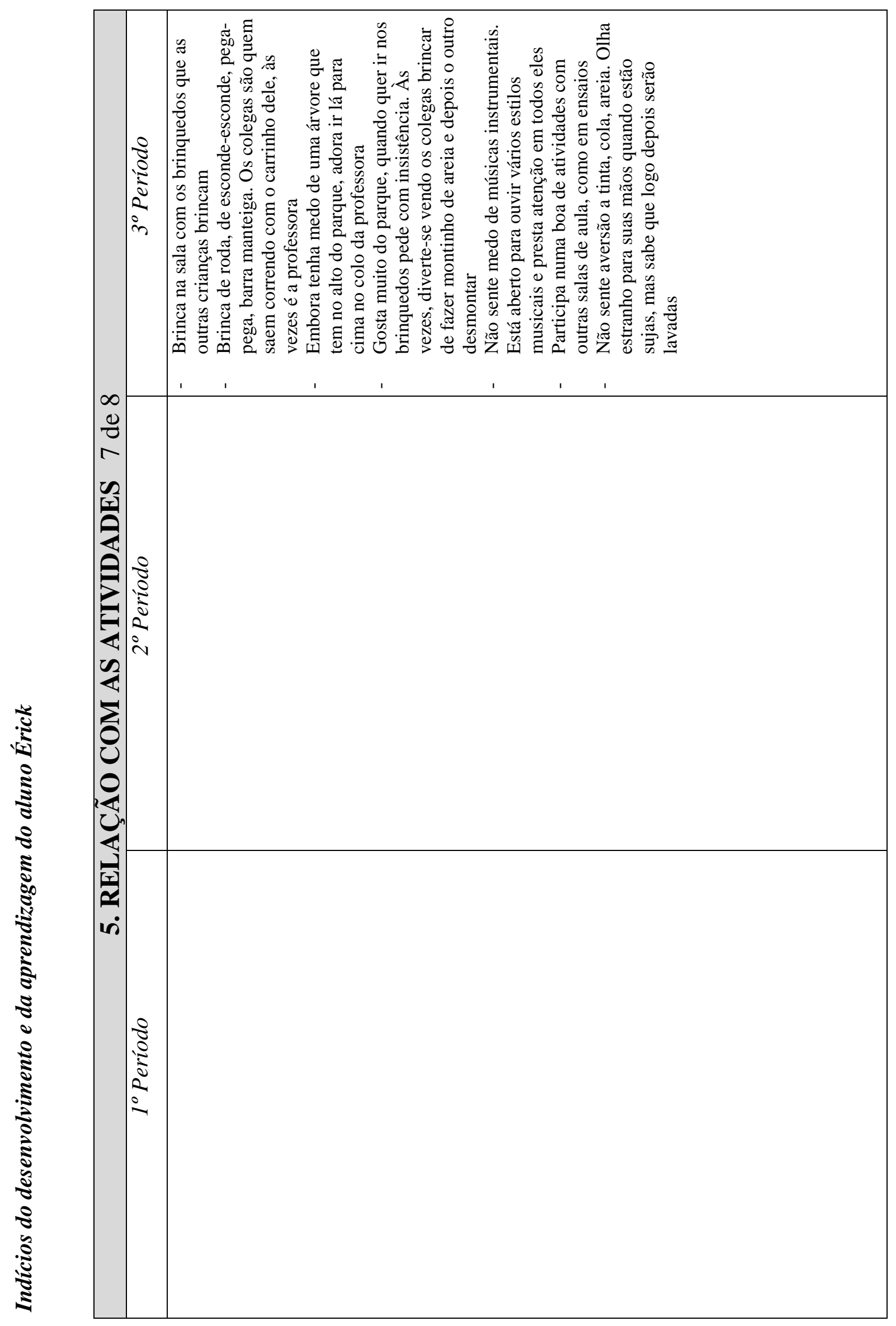




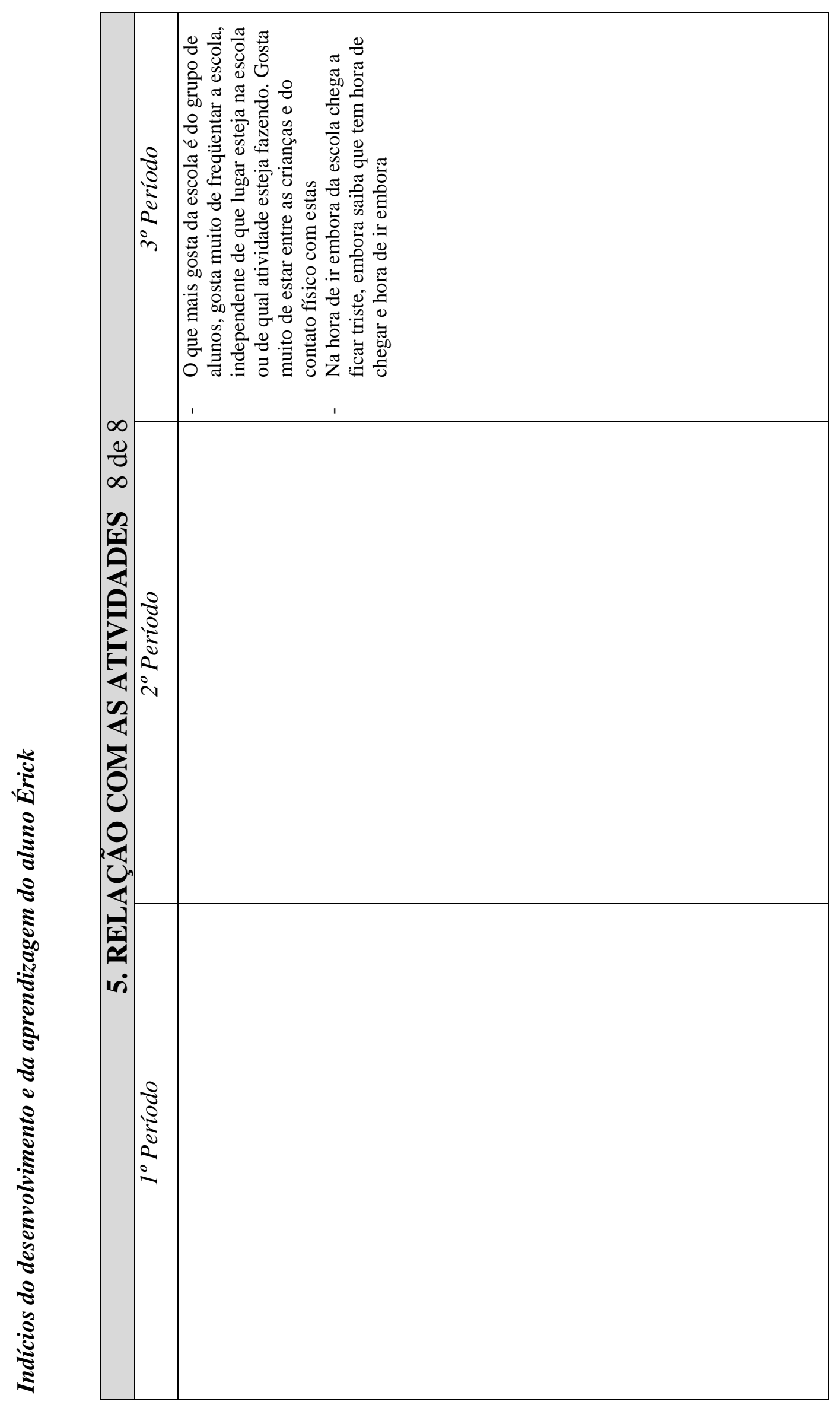


INDÍCIOS DO DESENVOLVIMENTO E DA APRENDIZAGEM DO ALUNO ÍTALO JÚLIO 


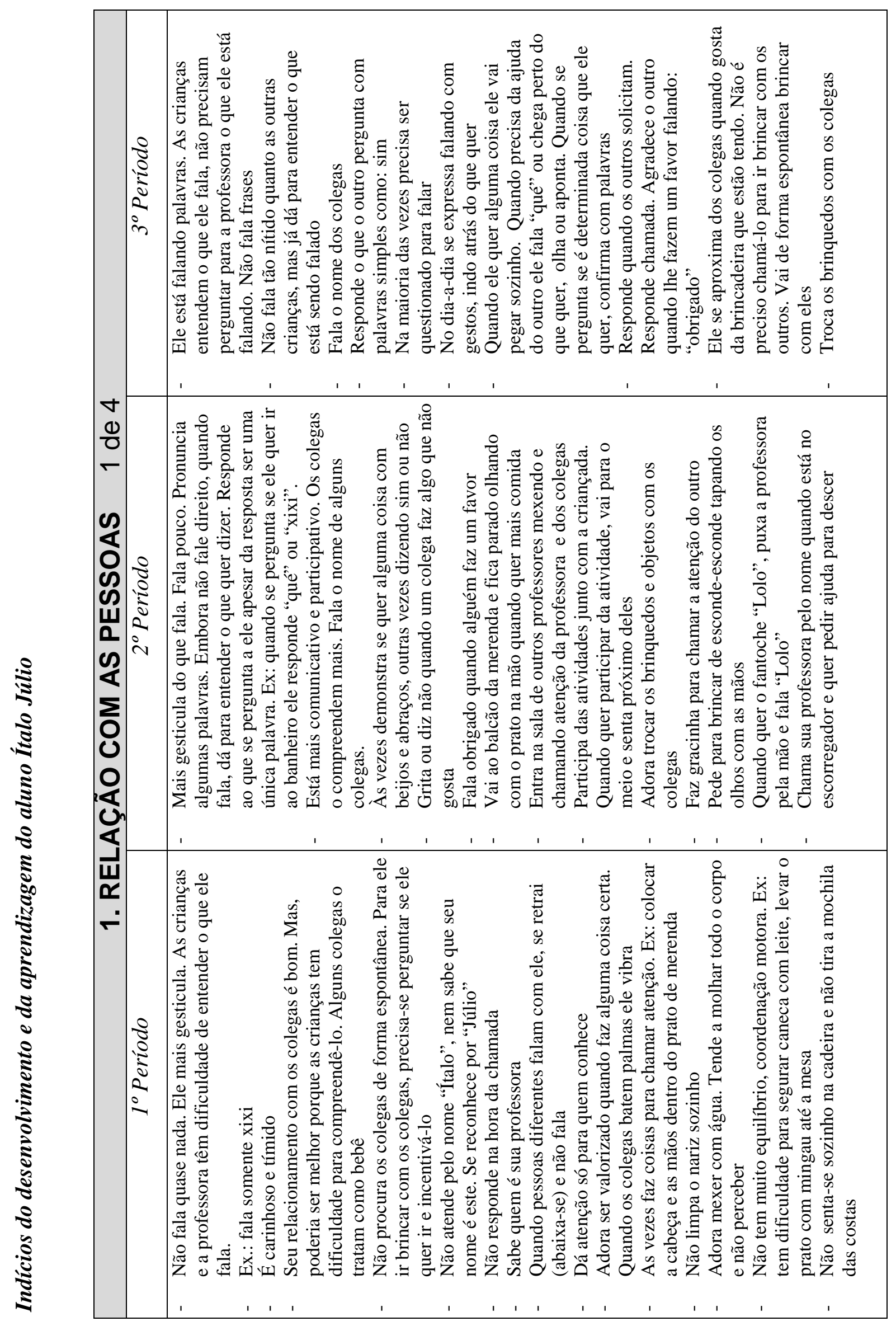




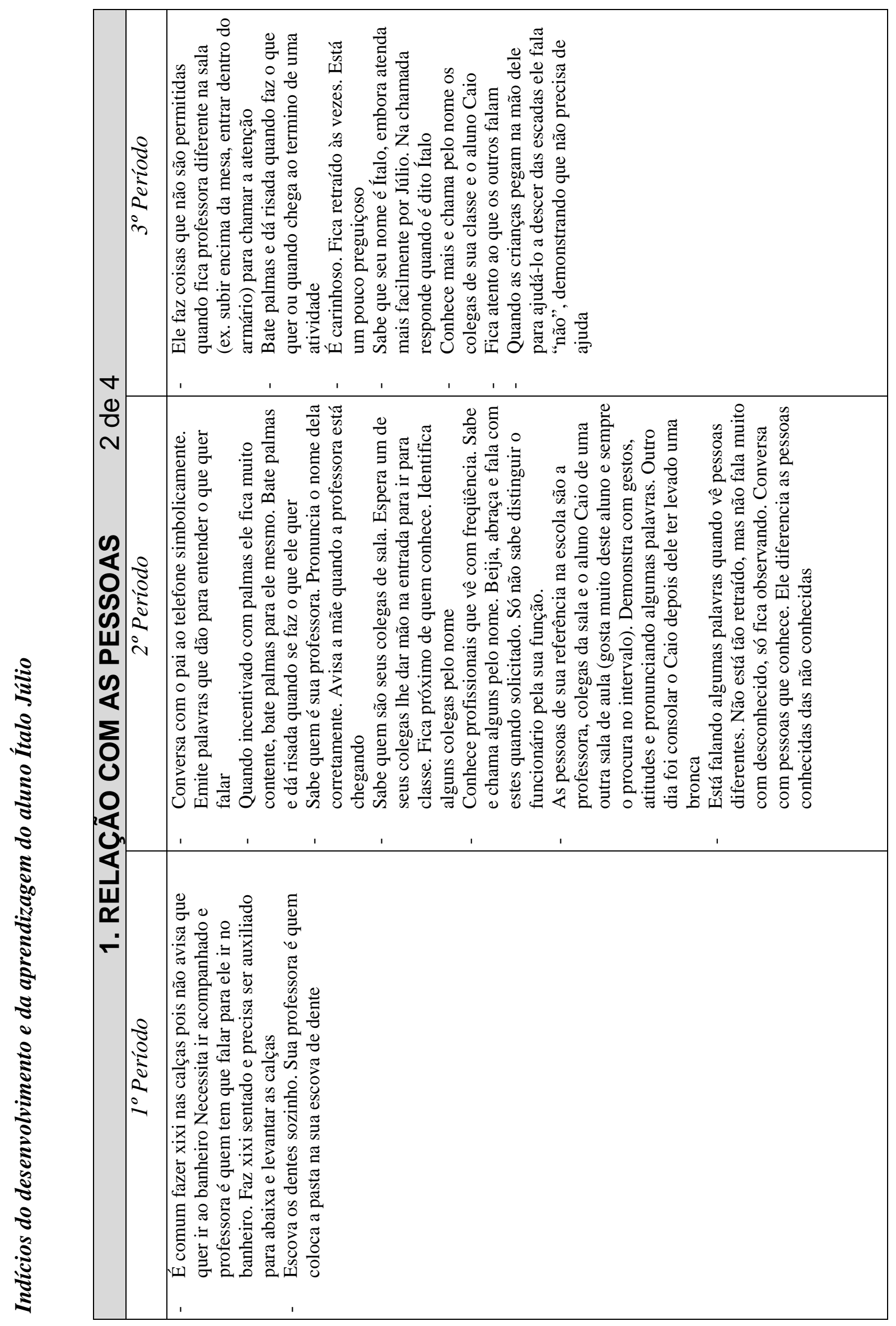




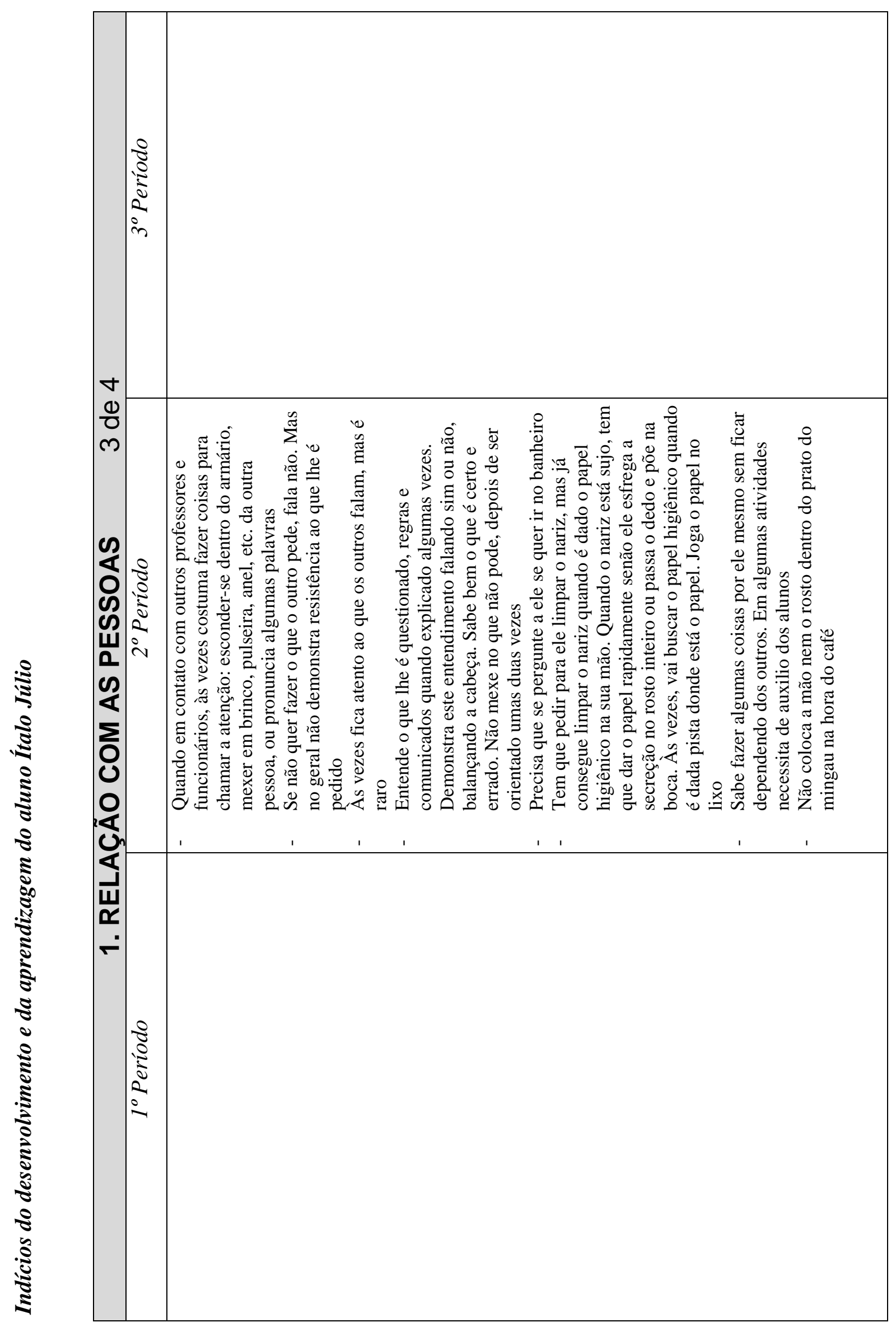




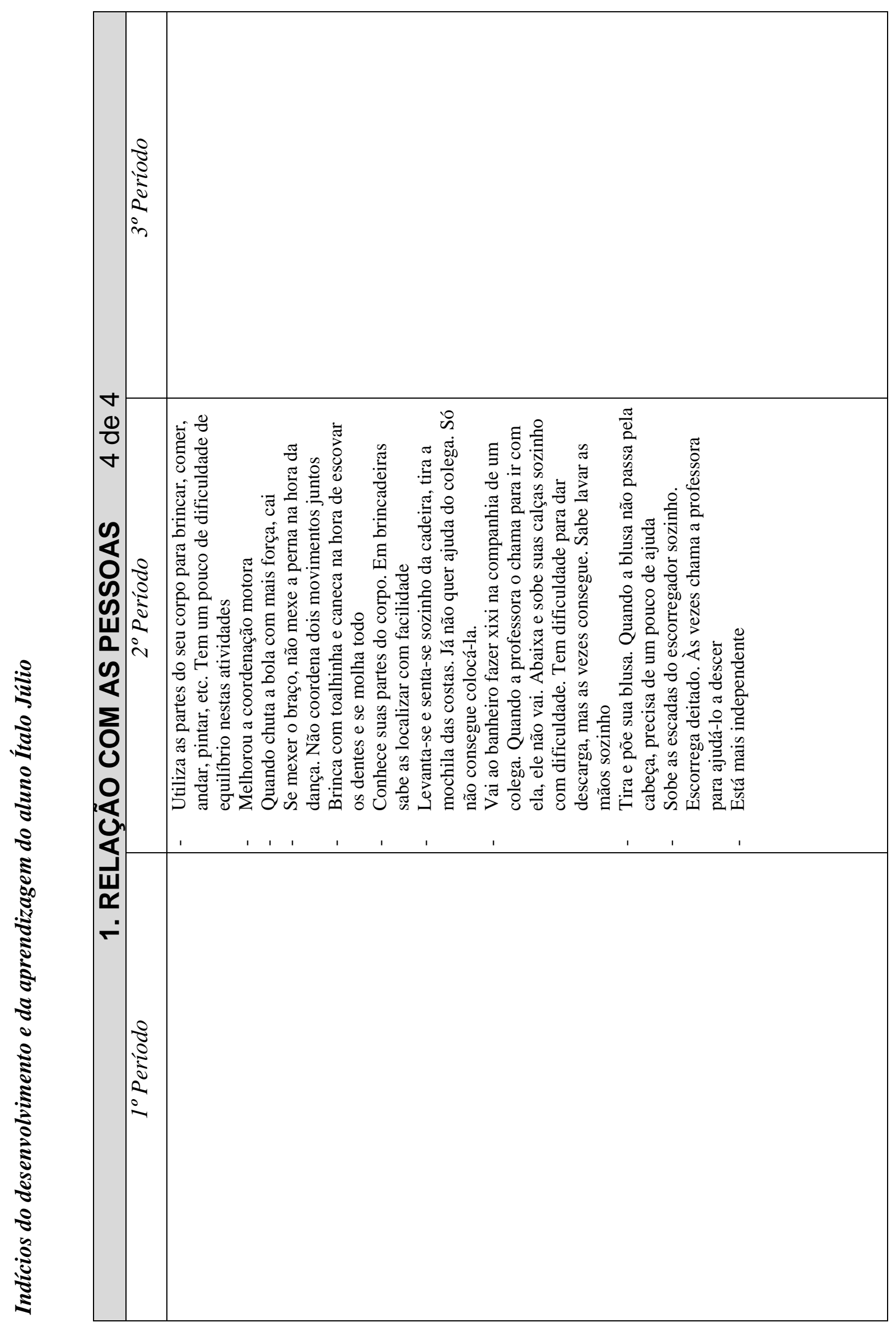




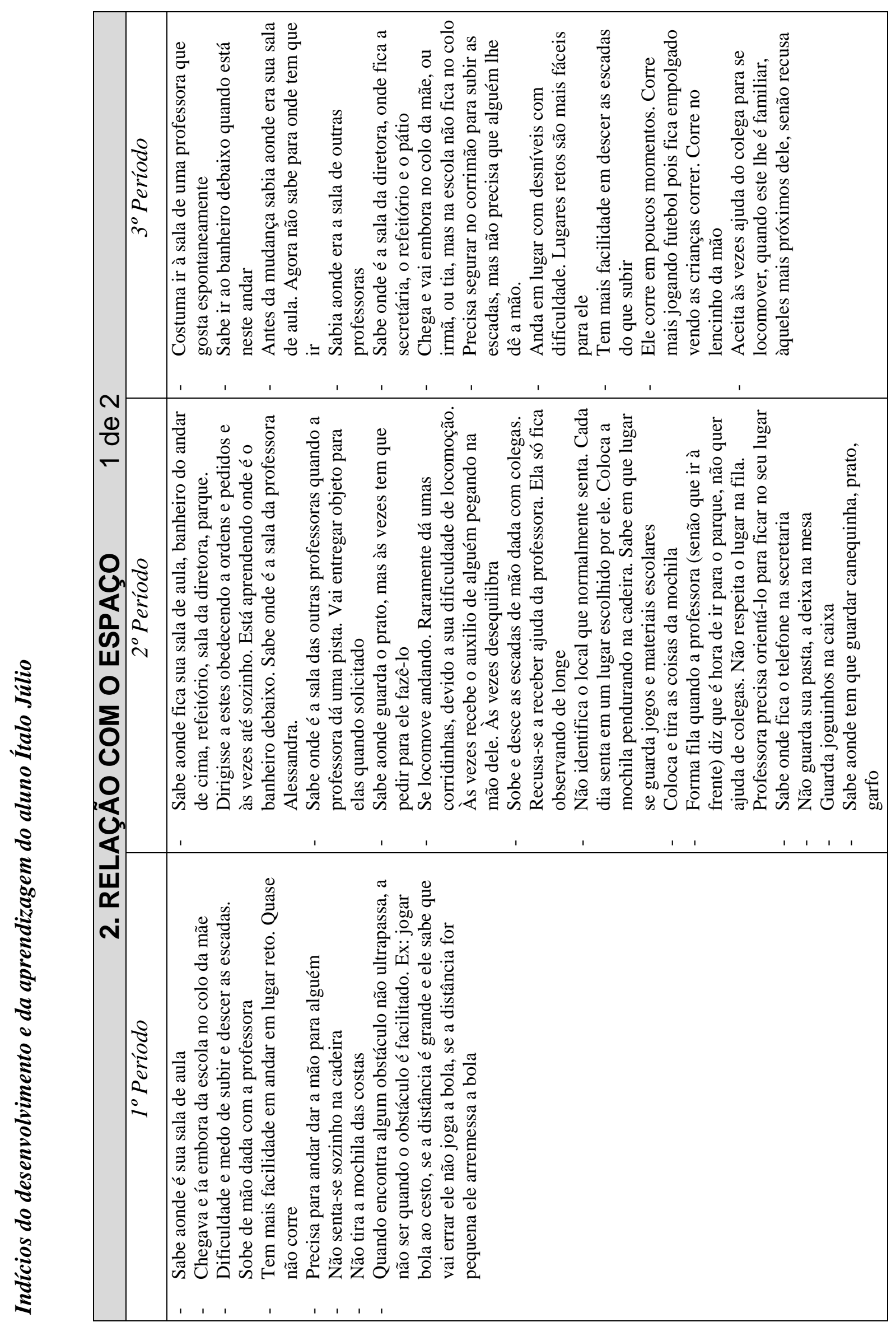




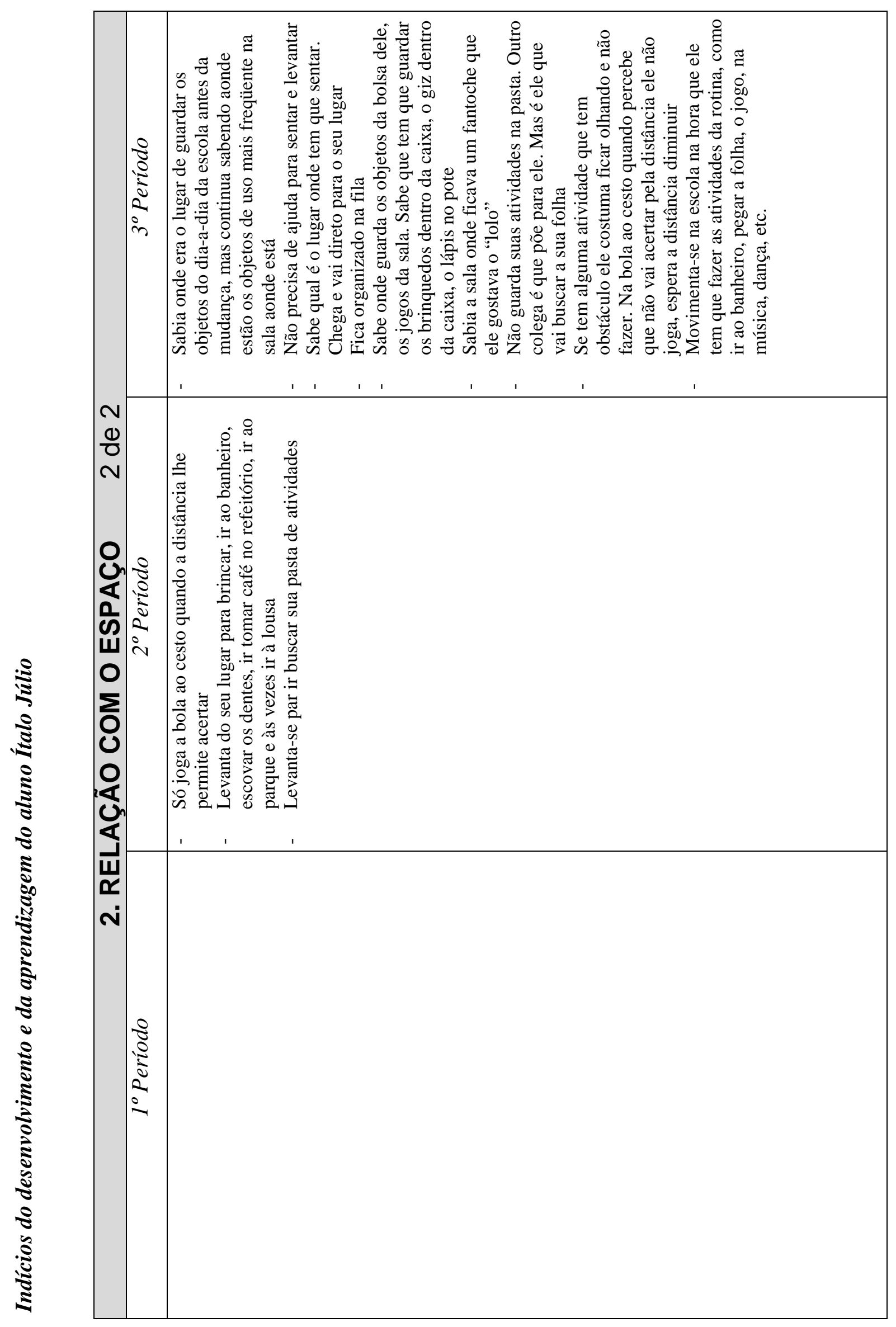




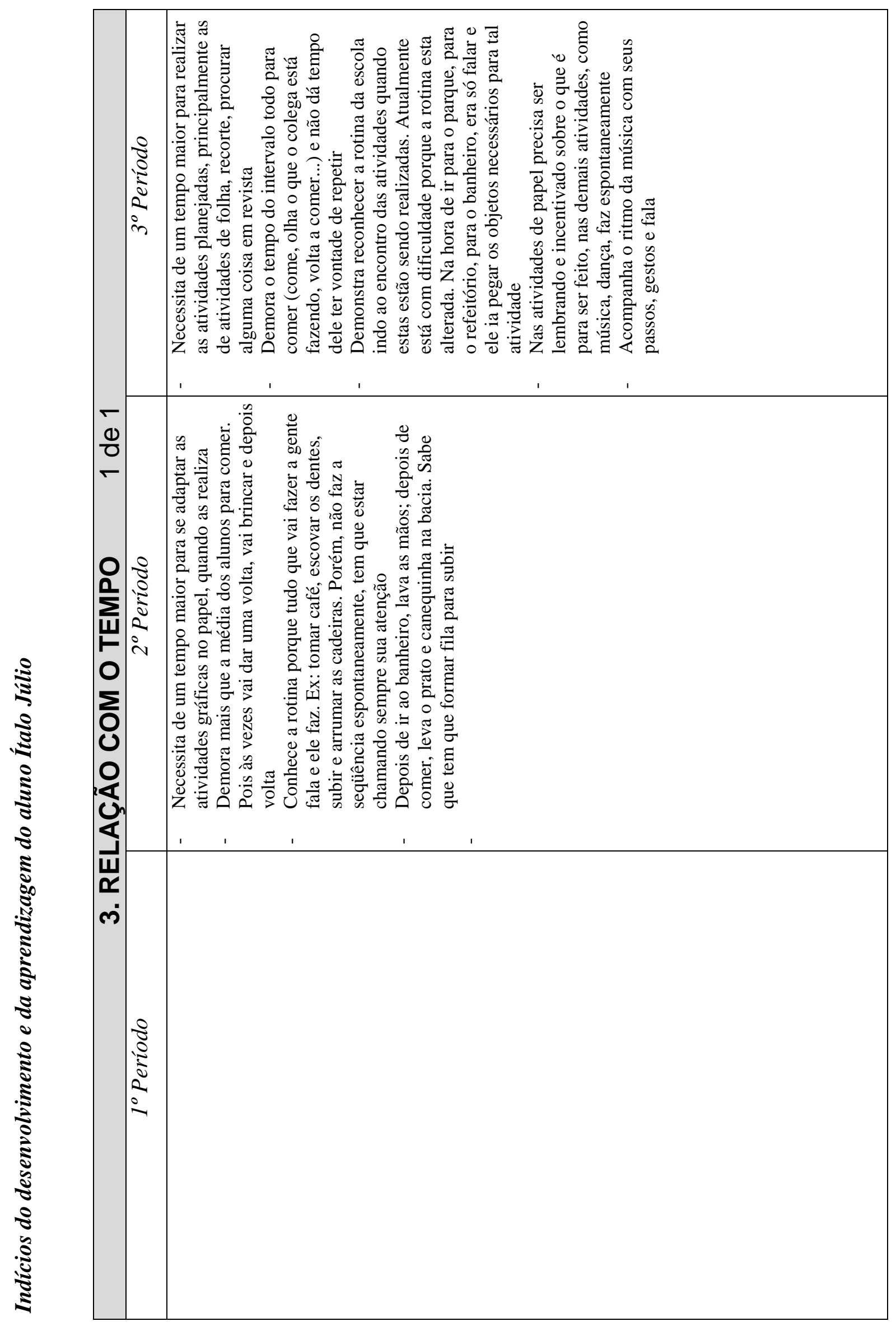




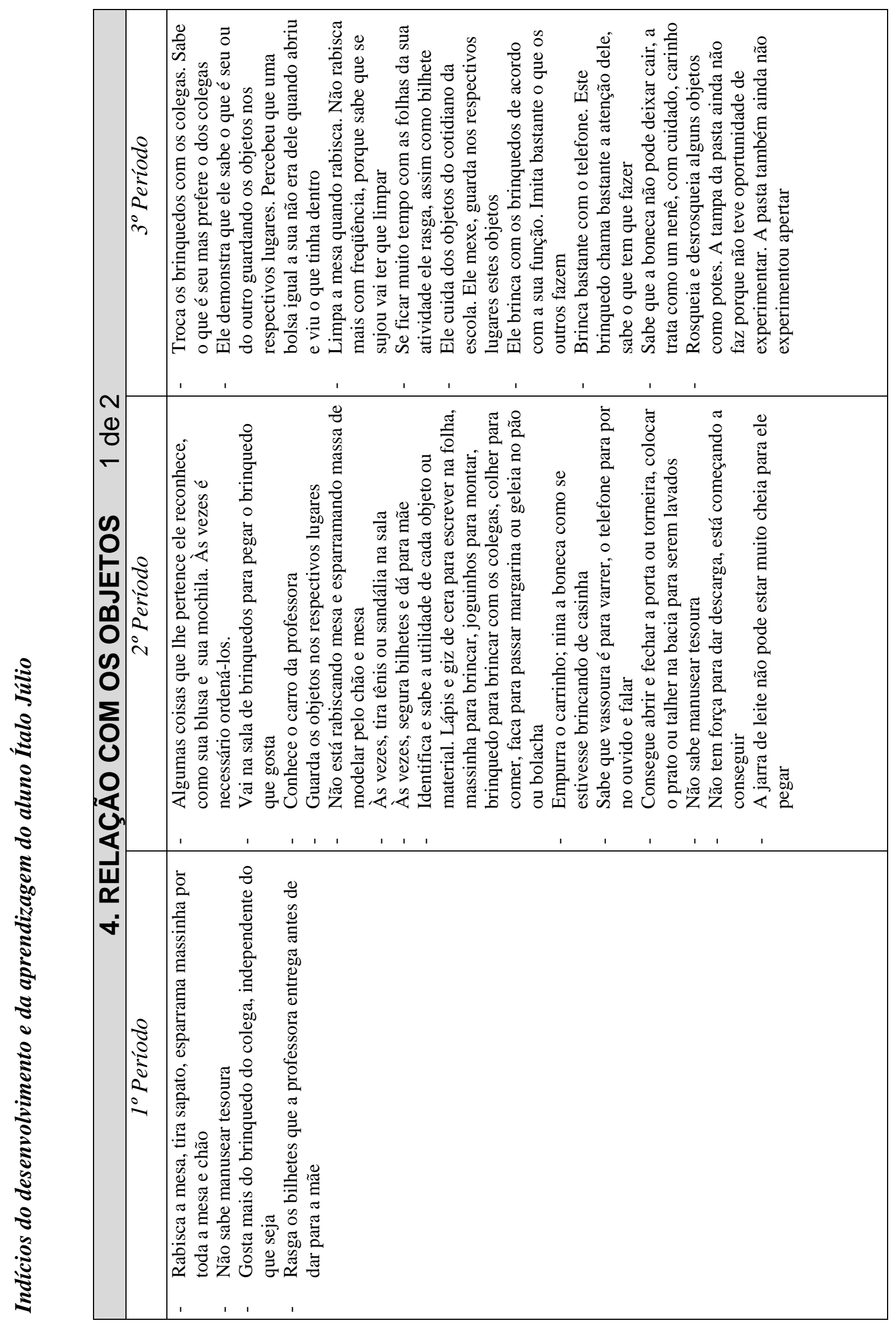




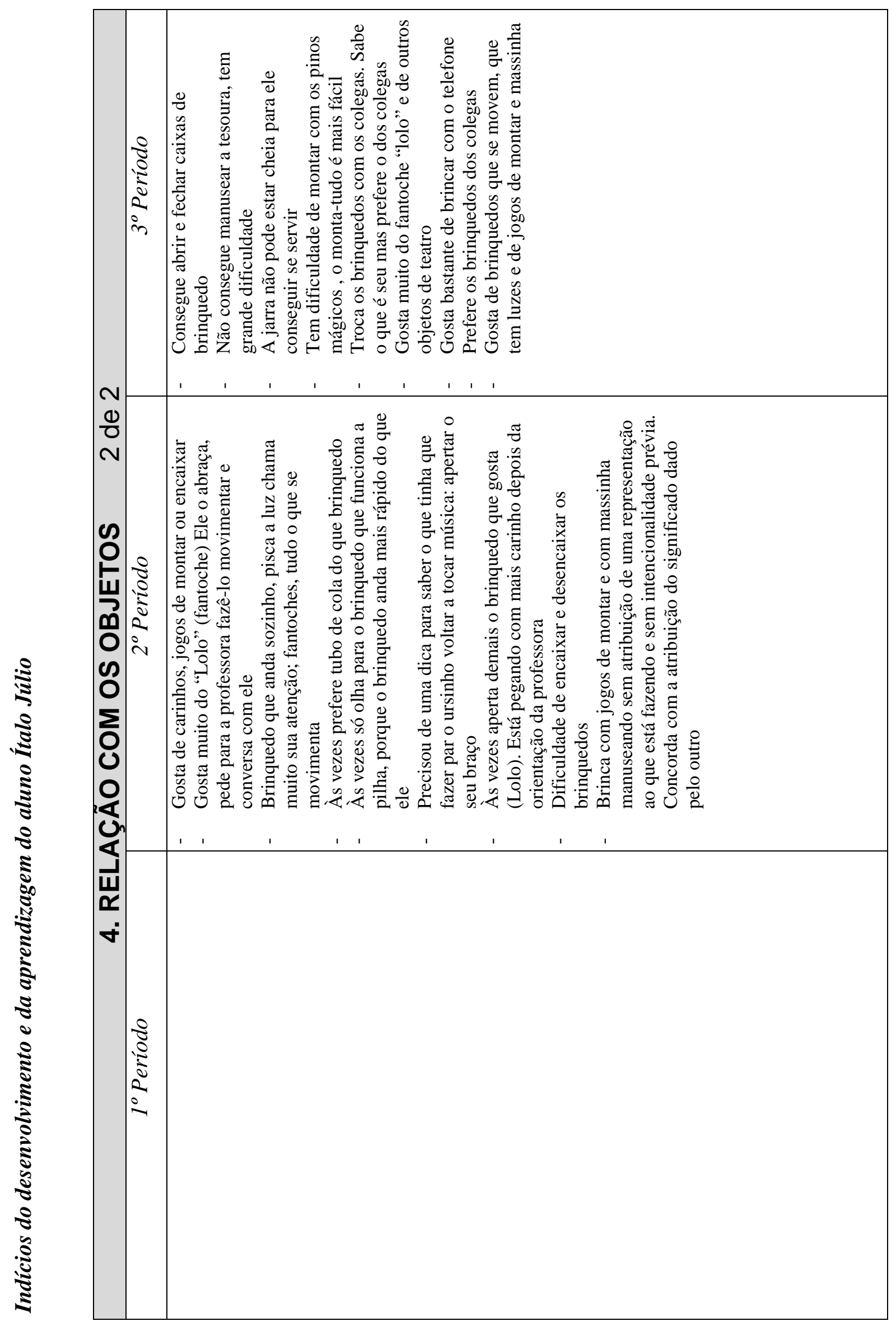




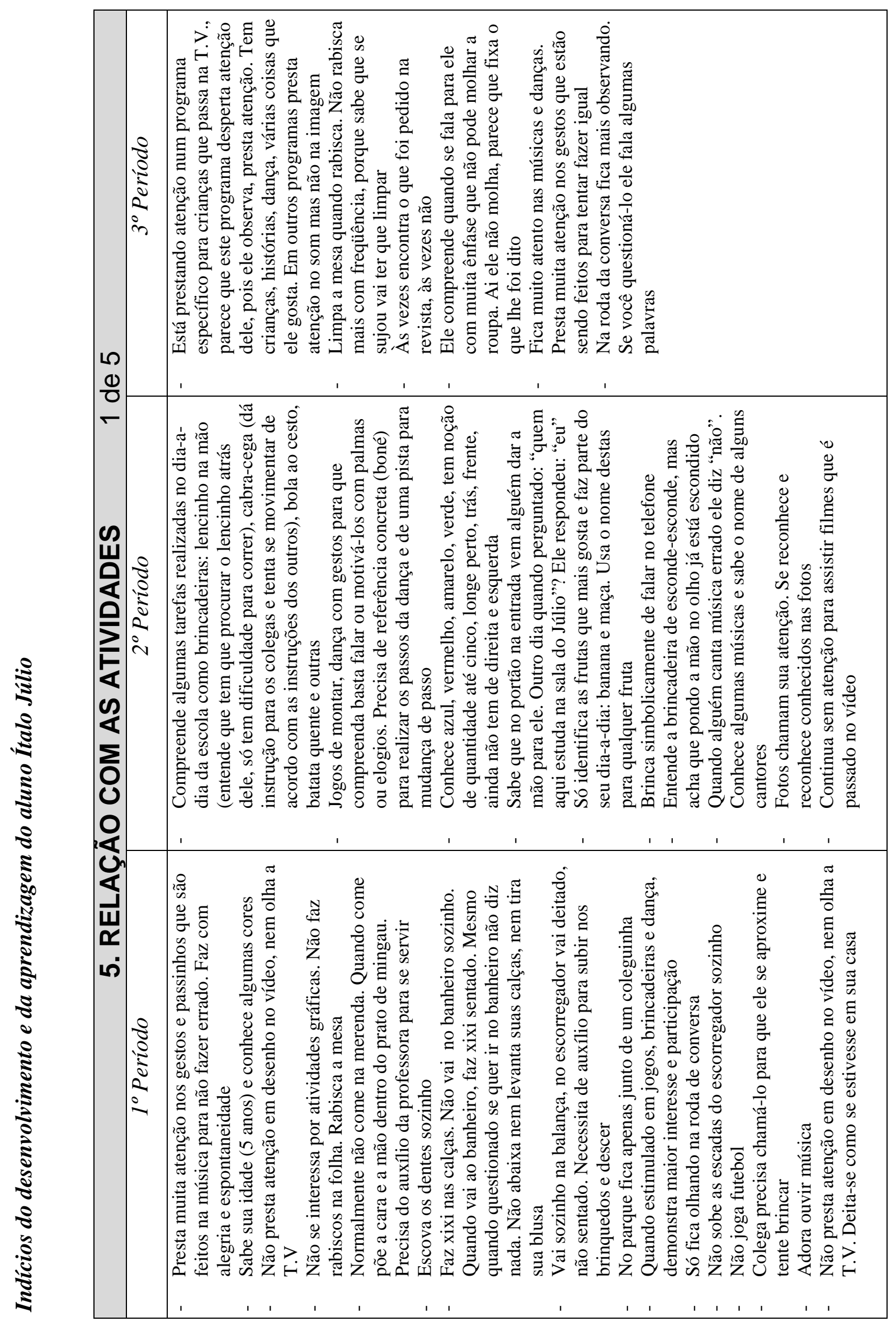




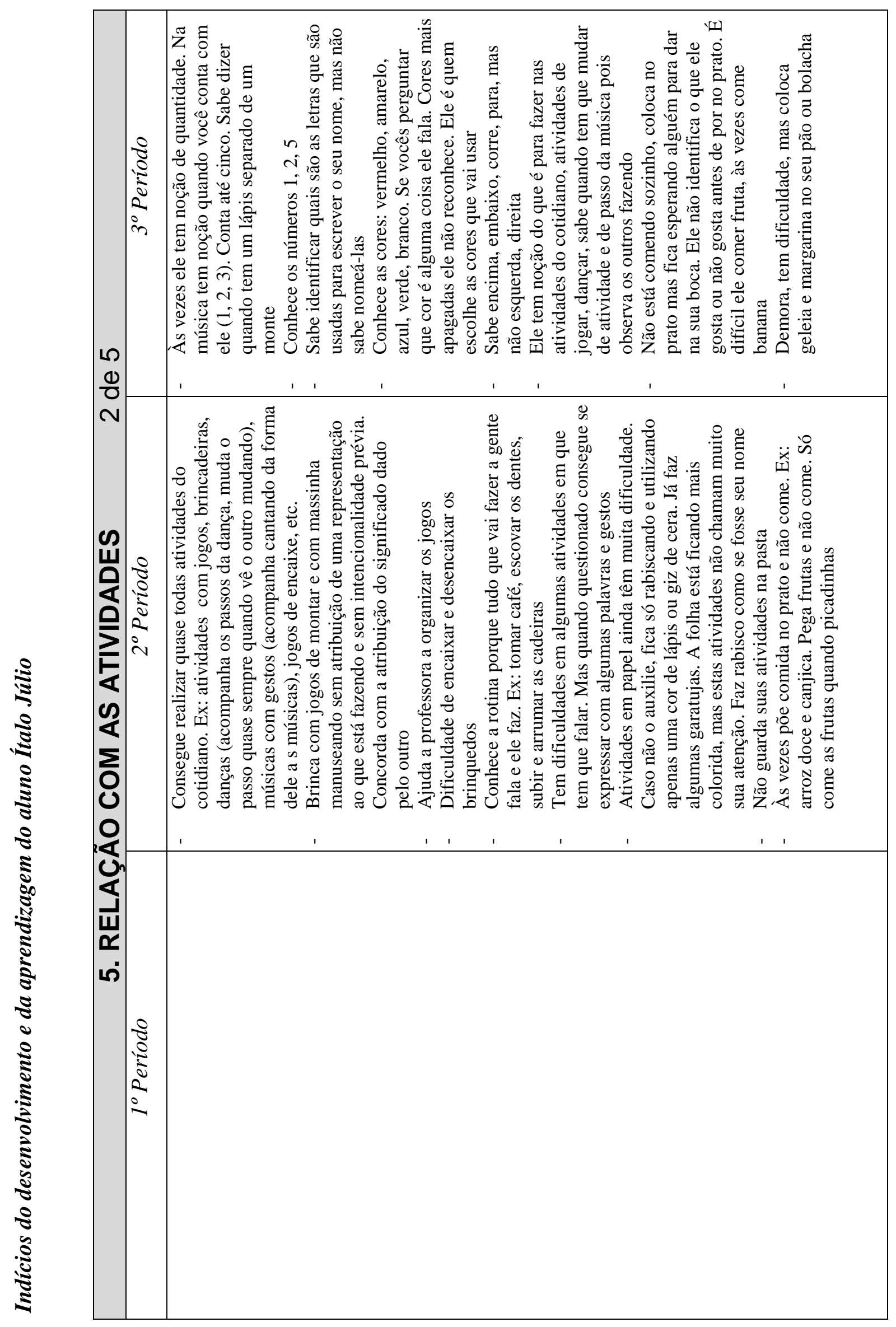




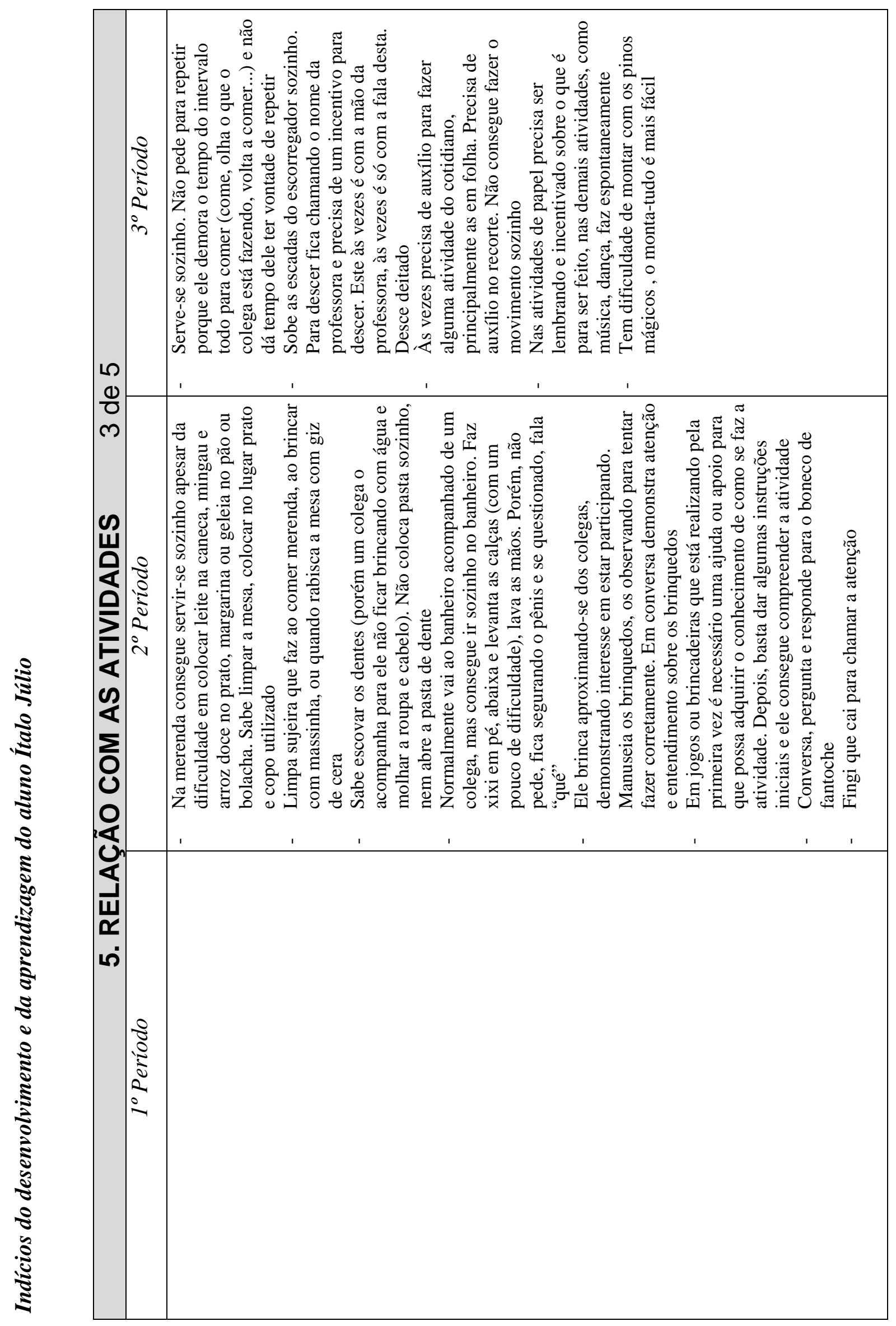




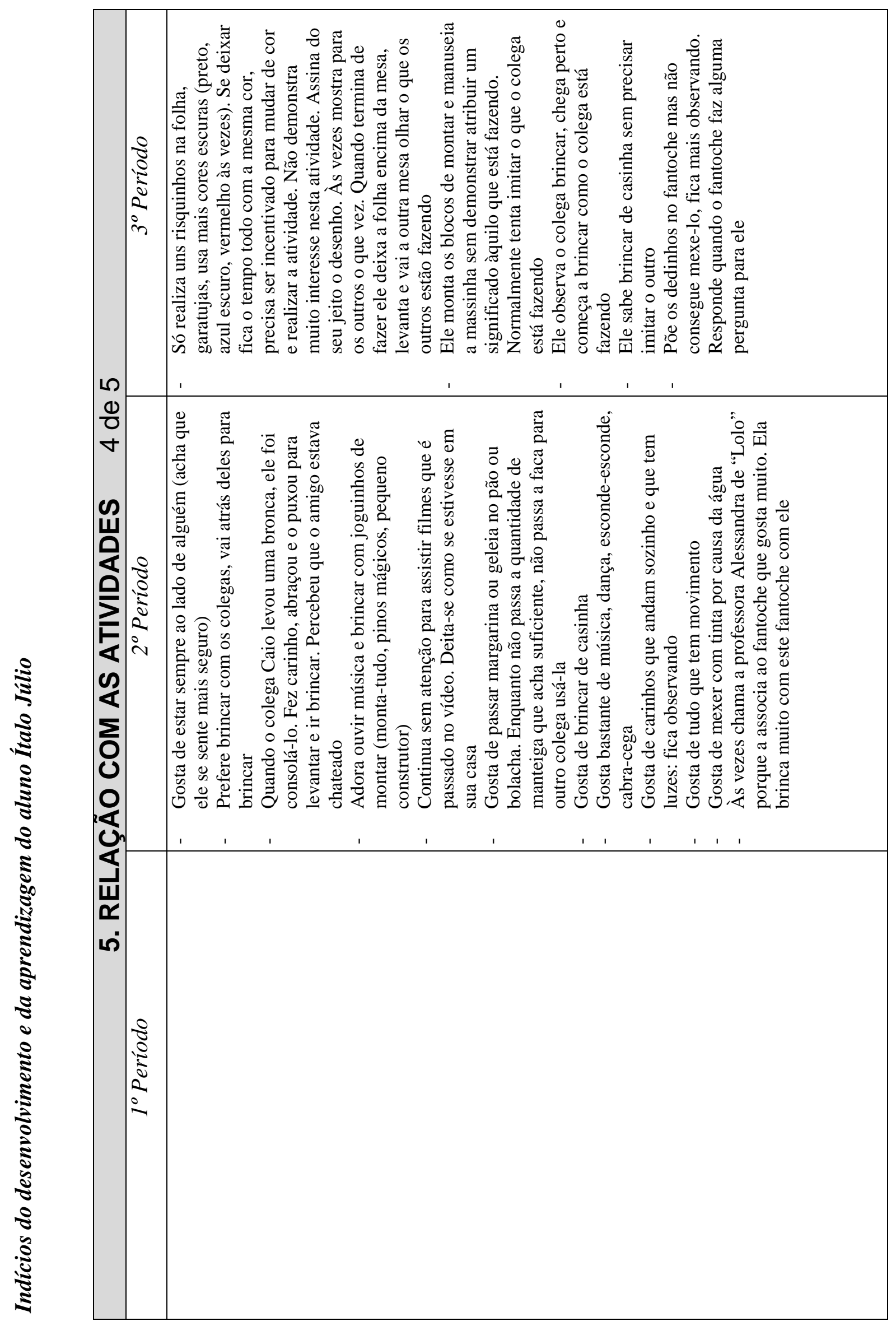



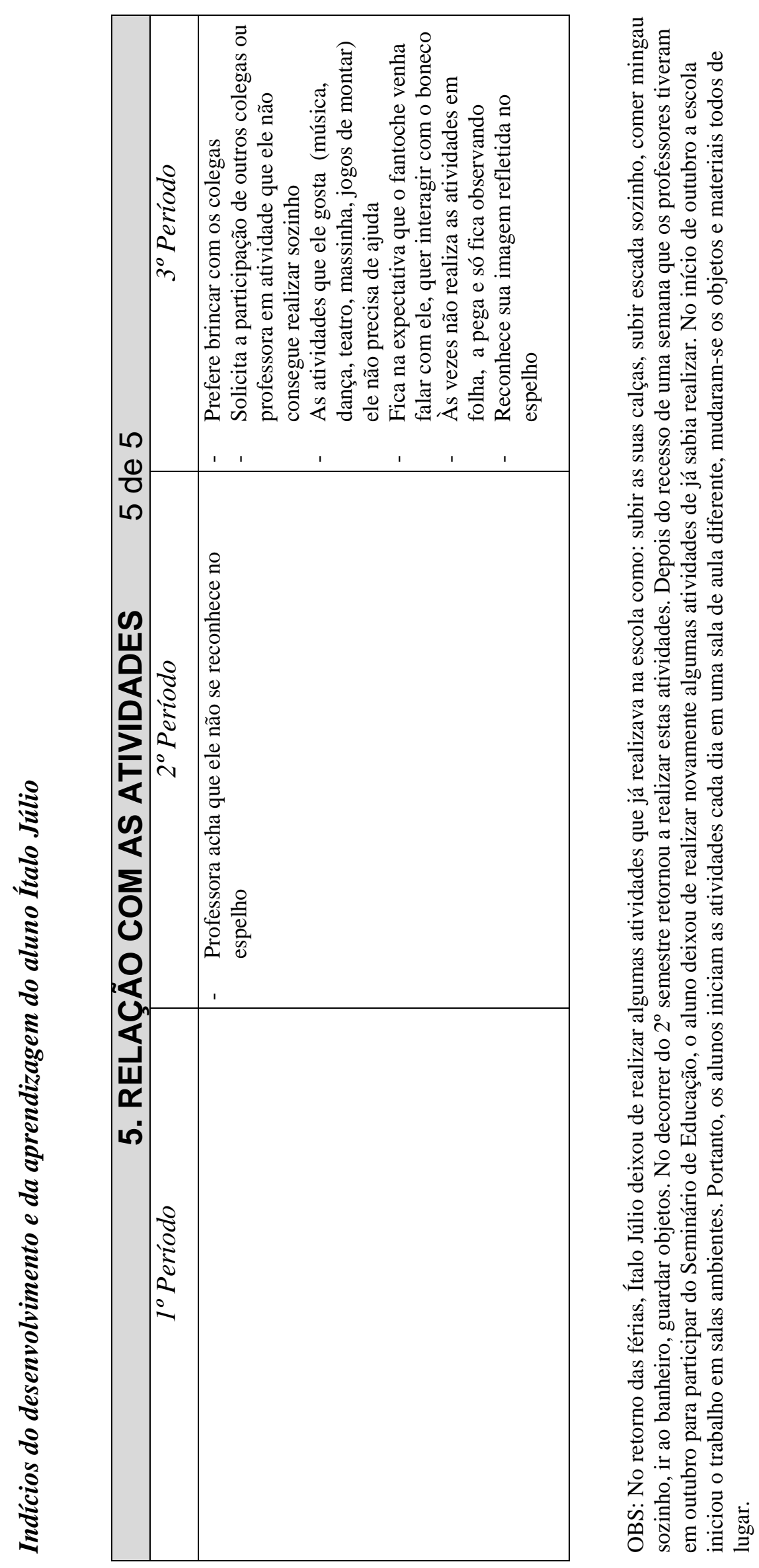
SOLICITAÇÃO DE AUTORIZAÇÃ̃ PARA A SMECE DA CIDADE DE MAUÁ 
Solicitação de autorização para a SMECE da cidade de Mauá

Mauá, 07 de novembro de 2001

\section{À Secretaria de Educação, Cultura e Esportes}

Eu, Deigles Giacomelli Amaro, terapeuta ocupacional do Departamento de Educação Especial do Município estou cursando o programa de mestrado em Psicologia Escolar e Desenvolvimento Humano do Instituto de Psicologia da Universidade de São Paulo. Minha pesquisa tem como objetivo analisar o desenvolvimento da independência e autonomia de crianças com deficiência alunas do sistema regular de ensino.

Como funcionária desta Secretaria e considerando a importância de estarmos articulando a prática profissional e o estudo, gostaria de estar realizando o estudo de campo, com alunos de 5 a 6 anos com deficiência da Educação Infantil do Município. Para tal, venho por meio deste solicitar a autorização desta Secretaria para realizar este estudo e coleta de dados em algumas Escolas Municipais de Educação Infantil. Segue em anexo uma síntese do que se constituirá a pesquisa e o roteiro de observação para coleta de dados.

Coloco-me a disposição para eventuais esclarecimentos e divulgação dos dados obtidos na pesquisa.

Atenciosamente,

Deigles Giacomelli Amaro

Registro 1256 


\section{TERMO DE CONSENTIMENTO LIVRE E ESCLARECIDO}




\section{Termo de consentimento livre e esclarecido}

$\mathrm{Eu}$,

R. G. $\mathrm{n}^{\mathrm{o}}$ abaixo assinado (a), concordo em participar da pesquisa "Cotidiano e educação inclusiva: a aprendizagem de crianças com deficiência na escola regular", sob responsabilidade de Deigles Giacomelli Amaro, terapeuta ocupacional e pós-graduanda em Psicologia Escolar e Desenvolvimento Humano, pelo Instituto de Psicologia da Universidade de São Paulo.

Esta pesquisa tem por objetivo estudar por que, como e quais as relações estabelecidas no cotidiano escolar podem beneficiar o desenvolvimento e a aprendizagem de alunos com deficiência em uma perspectiva inclusiva de educação, em escolas de educação infantil. Ela será realizada através de entrevistas com os funcionários da escola em que o aluno de referência na pesquisa estuda e suas mães e, eventualmente, em observações do aluno em atividades do seu cotidiano na escola. As entrevistas serão gravadas e será realizado registro escrito das observações. Incluiremos também, como material de coleta de dados, relatórios realizados por seus professores.

Como participante da pesquisa, estou ciente dos meus direitos abaixo relacionados:

1. A garantia de receber a resposta a qualquer pergunta ou esclarecimento a qualquer dúvida relacionada à pesquisa;

2. A liberdade de retirar meu consentimento a qualquer momento e deixar de participar do estudo;

3. A segurança de que não ser identificado e que será mantido o caráter confidencial da informação relacionada com a minha privacidade.

Mauá, de de 2002 
Ficha Catalográfica preparada pelo Serviço de Biblioteca e Documentação do Instituto de Psicologia da USP

Amaro, D. G.

Indícios da aprendizagem de crianças com deficiência em escolas de educação infantil: roteiro de observação no cotidiano escolar./ Deigles Giacomelli Amaro. - São Paulo: s.n., 2004. - 252p.

Dissertação (mestrado) - Instituto de Psicologia da Universidade de São Paulo. Departamento de Psicologia da Aprendizagem, do Desenvolvimento e da Personalidade.

Orientador: Lino de Macedo.

1. Educação inclusiva 2. Cotidiano 3. Desenvolvimento 4. Aprendizagem 5. Deficientes I. Título. 